\title{
Trzy problemy współczesnej filozofii umysłu
}




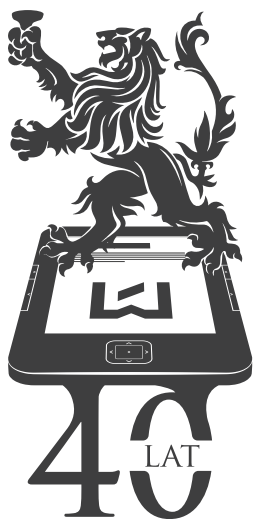

WYDAWNICTWA

UNIWERSYTETU 


\section{Trzy problemy współczesnej filozofii umysłu}


Tadusz Skalski - Uniwersytet Łódzki, Wydział Filozoficzno-Historyczny Katedra Logiki i Metodologii Nauk, 90-232 Łódź, ul. Kopcińskiego 16/18

\author{
RECENZENT \\ Elżbieta Kałuszyńska \\ OPRACOWANIE REDAKCYJNE \\ Joanna Balcerak \\ SKŁAD I ŁAMANIE \\ AGENT PR
}

PROJEKT OKŁADKI

Barbara Grzejszczak

CC Copyright by Uniwersytet Łódzki, Łódź 2013

Wydane przez Wydawnictwo Uniwersytetu Łódzkiego

Wydanie I. W.06356.13.0.M

\title{
ISBN (wersja drukowana) 978-83-7525-993-3 \\ ISBN (ebook) 978-83-7969-390-0
}

\author{
Wydawnictwo Uniwersytetu Łódzkiego \\ 90-131 Łódź, ul. Lindleya 8 \\ www.wydawnictwo.uni.lodz.pl \\ e-mail: ksiegarnia@uni.lodz.pl \\ tel. (42) 6655863 , faks (42) 6655862
}




\section{SPIS TREŚCI}

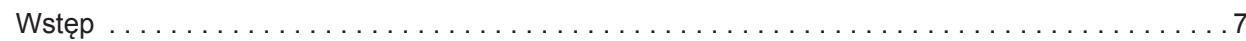

\section{CZĘŚĆ I. TKO}

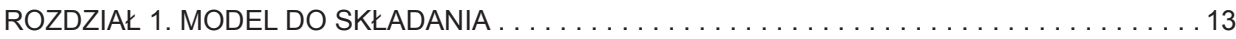

1. Dwie naturalizacje: naturalizacja przyrody i naturalizacja umysłu $\ldots \ldots \ldots \ldots \ldots \ldots 13$

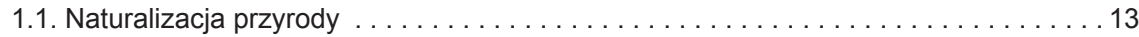

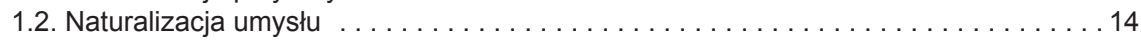

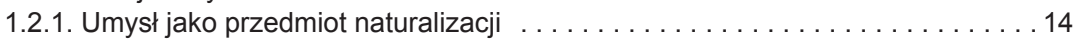

1.2.2. Pewna osobliwość związana z naturalizacją umysłu . . . . . . . . . . . . . . 15

1.3. Dwie naturalizacje (końcowa uwaga) . . . . . . . . . . . . . . . . . . . . 17

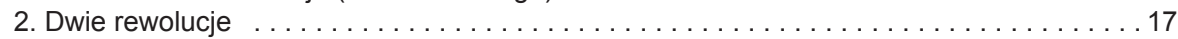

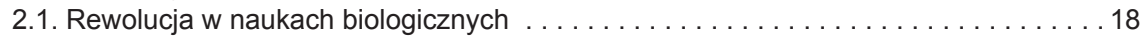

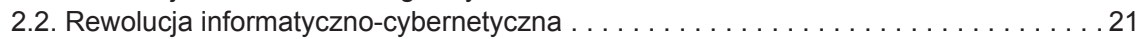

2.2.1 Szukanie podmiotu i rewolucja informatyczno-cybernetyczna . . . . . . . 22

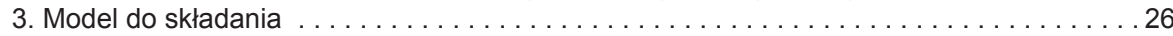

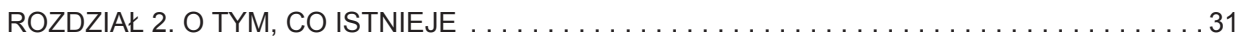

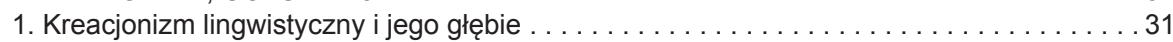

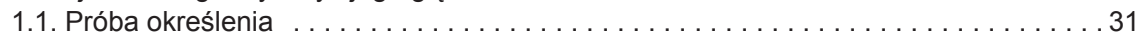

1.2. Realizm metafizyczny, wewnętrzny, naiwny... i normalny realizm . . . . . . . . . 33

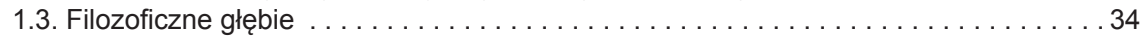

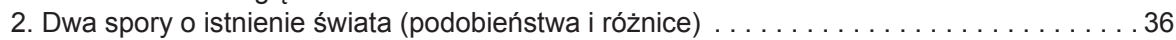

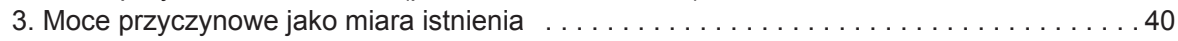

3.1. Próba dokładniejszego określenia pojęcia mocy przyczynowych $\ldots \ldots \ldots \ldots \ldots 41$

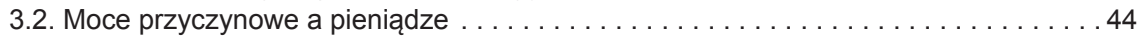

3.3. Niektóre stare filozoficzne spory i moce przyczynowe . . . . . . . . . . . . . . . 46

3.4. Umysł jako software i moce przyczynowe . . . . . . . . . . . . . . . . . . . . 49

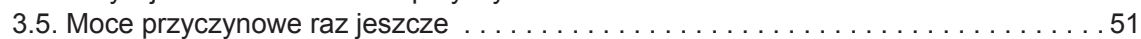

ROZDZIAŁ 3. NATURALIZACJA OBRAZÓW I LUDZI (CZYLI KILKA WSPÓŁCZESNYCH TEORII UMYSŁU W SPOSÓB OBRAZOWY PRZEDSTAWIONYCH) $\ldots \ldots \ldots \ldots \ldots \ldots \ldots . \ldots 53$

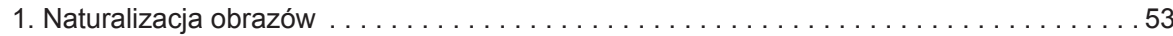

1.1. Dwa sposoby opisu, dwa języki, dwa rodzaje własności $\ldots \ldots \ldots \ldots \ldots \ldots \ldots . \ldots 3$

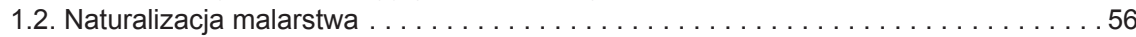

1.2.1. Gatunkowa (typiczna) teoria identyczności . . . . . . . . . . . . . . 57

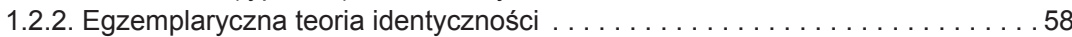

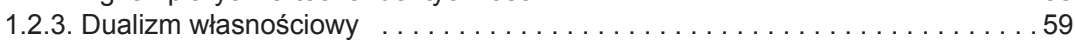

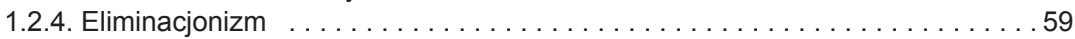




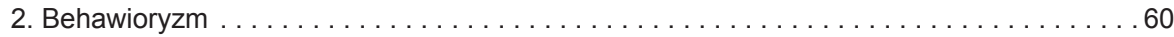

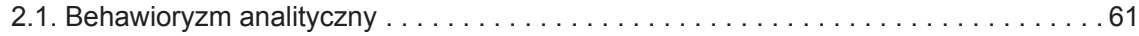

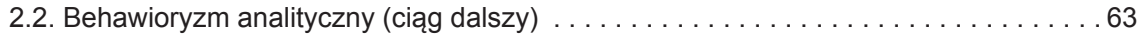

2.3. Przykłady i propozycje . . . . . . . . . . . . . . . . . . . . . . 65

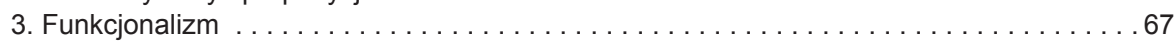

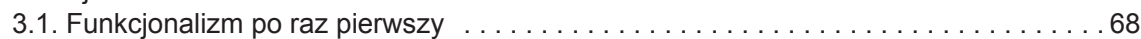

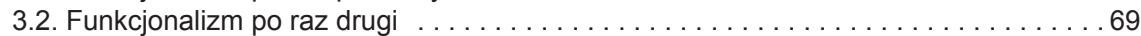

\section{CZĘŚĆ II. PROBLEMY}

ROZDZIAŁ 4. PROBLEMY Z POJĘCIEM ZACHOWANIA $\ldots \ldots \ldots \ldots \ldots \ldots \ldots \ldots \ldots \ldots$

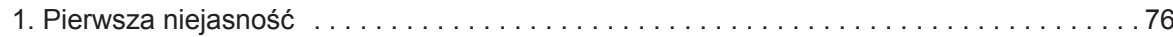

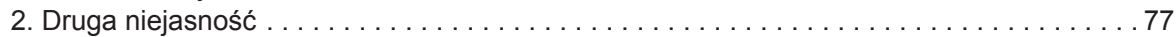

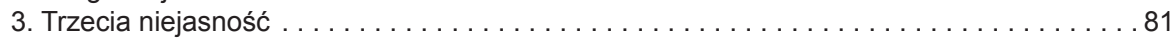

Addenda . . . . . . . . . . . . . . . . . . . . . . . . . . . . . . 84

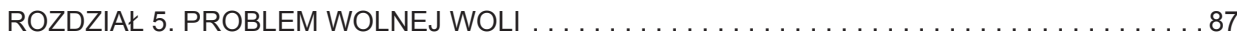

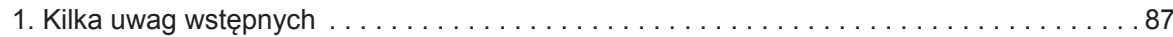

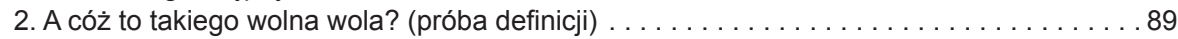

3. Wersja teologiczna problemu wolnej woli $\ldots \ldots \ldots \ldots \ldots \ldots \ldots \ldots \ldots \ldots \ldots \ldots \ldots \ldots \ldots$

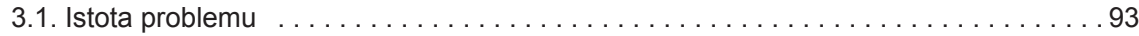

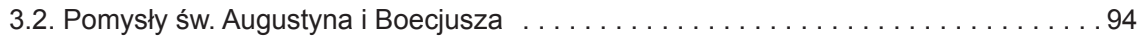

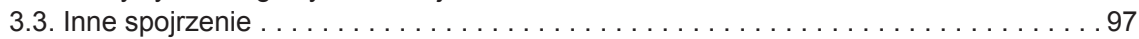

3.4. Propozycja rozwiązania problemu wolnej woli w wersji teologicznej . . . . . . . . . . . 98

3.4.1. Zabawa w Pana Boga . . . . . . . . . . . . . . . . . . . . . . . . . . 100

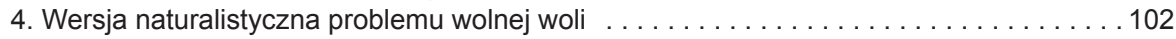

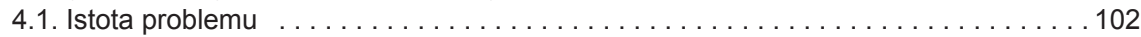

4.2. Doskonała teoria profesora Prognozy . . . . . . . . . . . . . . . . . . . . 104

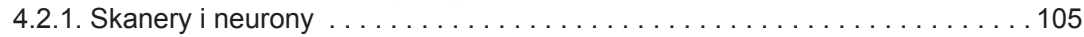

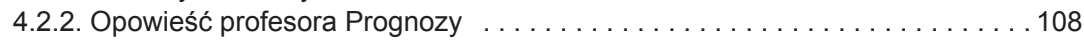

4.2.3. Ludowa metafizyka, sprawstwo i wolna wola . . . . . . . . . . . 111

ROZDZIAŁ 6. PROBLEM QUALIÓW . . . . . . . . . . . . . . . . . . . . . . . . . 115

1. Problem qualiów (krótkie wprowadzenie) … . . . . . . . . . . . . . . 115

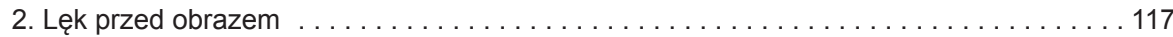

2.1. Krzesło i jego obraz . . . . . . . . . . . . . . . . . . . . . . . . . 117

3. Zmniejszanie lęku przed obrazem . . . . . . . . . . . . . . . . . . . . . 118

3.1. Etap pierwszy . . . . . . . . . . . . . . . . . . . . . 118

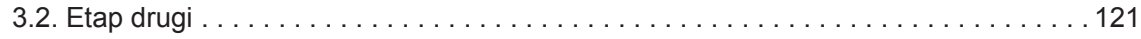

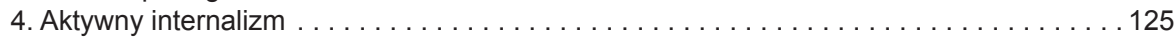

4.1. Pochodzenie nazwy . . . . . . . . . . . . . . . . . . . . . . . . 125

4.2. Promocja aktywnego internalizmu . . . . . . . . . . . . . . . . . . . . . . 126

5. Przypadek Stefana a filozofia percepcji (oraz kilka różnych „ale”) . . . . . . . . . . . 130

Epilog . . . . . . . . . . . . . . . . . . . . . . . . . . . . . 132

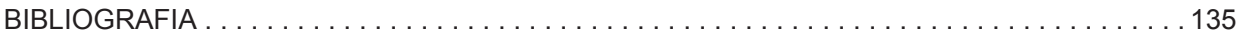




\section{WSTĘP}

Współczesna, analityczna filozofia umysłu jest skrajnie materialistyczna; jest to filozofia umysłu bez umysłu. Olbrzymia większość badaczy zajmujących się umysłem - dotyczy to nie tylko filozofów, ale i przedstawicieli licznych nauk szczegółowych - uznała, że byt, zwany niegdyś duchem, duszą, świadomością, jaźnią lub niematerialnym umysłem, po prostu nie istnieje. Wiara $w$ istnienie takiego bytu nie jest już, jak się powiada, opcją filozoficzną, ale - w przeważającej opinii - rodzajem zabobonu. Współczesnemu filozofowi umysłu nie uchodzi wierzyć w duchy. Dualizm substancjalny jest nie do przyjęcia!

Filozofia zachodnia trwa i rozwija się przez ponad dwa i pół tysiąca lat. Przez nieomal cały ten długi czas duch - pod taką bądź inną postacią - był obecny w rozważaniach olbrzymiej większości najbardziej znanych i najbardziej wpływowych filozofów. Jeszcze w latach czterdziestych XX wieku. Gilbert Ryle (Ryle 1970) określa kartezjanizm mianem teorii oficjalnej, a dogmat o duchu w maszynie uważa za jeden z najbardziej rozpowszechnionych mitów (również wśród filozofów). Cóż takiego stało się w przeciągu ostatnich kilkudziesięciu lat? Dlaczego teoria uchodząca do niedawna za oficjalną tak szybko i w opinii tak wielu filozofów uznana została za rodzaj zabobonu? Czy wykryto w niej jakieś wady, których wcześniej nie dostrzegano; czy filozofowie przedstawili jakieś nowe nieodparte argumenty? Nic z tych rzeczy. Filozoficzne względy - wydaje się - nie odegrały tu żadnej roli. Zadecydowały o tym dwie rzeczy - rozwój nauk biologicznych oraz tzw. rewolucja informatyczna, a zwłaszcza badania nad sztuczną inteligencją. Postępy nauk biologicznych przekonują nas o tym, że ciała ludzi są nieodłączną częścią materialnej przyrody. Postępy badań nad sztuczną inteligencją zdają się dowodzić z kolei, że wytworzenie robota posiadającego wszystkie mentalne atrybuty człowieczeństwa jest kwestią niezbyt odległej przyszłości. Spór pomiędzy tzw. bilogistami i tzw. obliczeniowcami jest - z interesującego nas tutaj punktu widzenia - kwestią drugorzędną. Rewolucje te są na poziomie inżynierskiej praktyki i technologii w znacznej mierze komplementarne - ludzkie organy (póki co, te które uległy uszkodzeniu lub utraciły sprawność) są z rosnącym powodzeniem zastępowane przez fabrycznie wytworzone artefakty, a sztuczna inteligencja coraz śmielej sięga po biologiczną tkankę. Wszystko to łącznie uzasadnia przypuszczenie, że za czas jakiś biotechnologia osiągnie taki stopień rozwoju, że projektowanie i wytwarzanie istot ludzkich, półludzkich lub nadludzkich metodą 
czysto przemysłową stanie się w pełni możliwe. I jakże w takiej sytuacji przechować wiarę w duchy? Dualista w fabryce ludzi byłby równie dziwaczną postacią jak dualista w fabryce samochodów. Duch został przegnany, ostała się jeno cielesna maszyna!

Czym w takim razie zajmuje się współczesna filozofia umysłu? Badanie ciała to wszak zajęcie dla nauk szczegółowych. Jeżeli filozofowie koniecznie chcą brać udział w debacie na temat ciała, to czy przynajmniej nie powinni zmienić nazwy swej profesji na filozofia ciała lub, jeszcze lepiej, na filozofia mózgu. Określenie filozofia mózgu brzmiałoby jednak równie śmiesznie jak filozofia wątroby lub filozofia żołądka. Filozofowie zaś to ludzie poważni; niekiedy śmiertelnie poważni. Filozofia umysłu brzmi bardziej dostojnie i prestiżowo. Względy powagi i prestiżu nie są jednak w tym przypadku najważniejsze. Duch został przegoniony z maszyny, ale pozostała po nim w spadku kłopotliwa masa upadłościowa. Filozofowie umysłu zmienili się w syndyków owego dziedzictwa i zachowali w ten sposób miejsca pracy oraz tradycyjną nazwę. Sprzątanie po niematerialnym umyśle - to główne zajęcie współczesnych filozofów, a kłopoty i przeszkody, które towarzyszą tej pracochłonnej działalności składają się na problematykę współczesnej filozofii umysłu. Wytłumaczmy się jaśniej.

Duch, dusza, jaźń, świadomość czy też niematerialny umysł były miejscem, w którym to tradycyjnie umieszczano różne dobrze skądinąd znane byty, jako to: myśli, wrażenia, wspomnienia, wyobrażenia, przekonania, sympatie, antypatie itd., itd. Uznajemy, że ducha nie ma. Ale co począć z lokatorami? Wraz z eliminacją niematerialnego umysłu myśli, wrażenia, wspomnienia, wyobrażenia itd. znalazły się „na bruku”. Próby znalezienia dla nich miejsca w materialnym świecie - to główne zajęcie współczesnych miłośników mądrości, a trudności, które się w ich trakcie pojawiają składają się na problematykę filozofii umysłu.

W książce tej zajmujemy się problemem wolnej woli, problem qualiów oraz trudnościami związanymi z kluczowym dla filozofii umysłu pojęciem zachowania. Pierwszy z tych problemów jest nieomal tak stary, jak sama filozofia, drugi uchodzi za jedno z najważniejszych i zarazem najtrudniejszych zagadnień naturalistycznie zorientowanej filozofii umysłu, natomiast kłopoty związane z pojęciem zachowania zasługują na szczególną uwagę dlatego, że jest ono jednym z najważniejszych pojęć filozofii umysłu. Podstawową racją, która zadecydowała o wyborze tych akurat tematów nie jest jednak ich ważność dla współczesnej problematyki (choć i ona odegrała pewną rolę). Autorowi tej książki wydaje się (być może mylnie), że w tych akurat (trzech) przypadkach ma coś względnie nowego i ciekawego do zaprezentowania.

Książka składa się z dwóch części. Problemom i próbom ich rozwiązania lub nowego ujęcia poświęcona jest jej druga część. W pierwszej, zatytułowanej Tło, został scharakteryzowany naturalizm współczesnej filozofii, przedstawiono też kilka najważniejszych współczesnych teorii umysłu. Poszczególne koncepcje i teorie prezentowane są nie tak, jak uczynili to ich pomysłodawcy, ale w taki sposób, w jaki uczyniłby to piszący niniejsze, gdyby sam był ich twórcą.

Praca ta jest daleka od zupełności i w żadnym razie nie może być uważana za kompendium wiedzy o omawianych problemach, a tym bardziej - o współczes- 
nej filozofii umysłu. Jest ona zaprzeczeniem encyklopedyczności; wiele ważnych tematów pomijam lub traktuję po macoszemu. Brak wielu istotnych szczegółów to niewątpliwa wada tej książki, ale i główne źródło jej zalet. Pomijając tłuszcz dat, nazwisk i cytatów zyskuję na jasności. Logiczne kośćce poszczególnych teorii stają się widoczne. Jeśli ktoś lubi oglądać szkielety, ceni dziwne pomysły i kocha eksperymenty myślowe, to znajdzie przyjemność w lekturze.

Idea napisania tej książki powstała w trakcie zajęć ze studentami filozofii. Przedstawiając różne współczesne teorie umysłu, szukałem takich form wyrazu, które są proste, obrazowe i zarazem trafiają w sedno. Niektóre dydaktyczne pomysły wydały mi się na tyle interesujące, że postanowiłem nadać im postać krótkich esejów, a gdy te zaczęły się rozrastać, powziąłem myśl o napisaniu książki.

Ostatnia uwaga. W pracy wykorzystałem (dokonując w nich odpowiednich zmian) dwa wcześniej opublikowane artykuły (Model do składania, „Ruch Filozoficzny” 2003, nr 2; Doskonała teoria profesora Prognozy, „Filozofia Nauki” 2003, $\mathrm{nr} 1(41))$. 

Część I TKO 

Rozdział pierwszy

\section{MODEL DO SKŁADANIA}

\section{Dwie naturalizacje: naturalizacja przyrody i naturalizacja umysłu}

\subsection{Naturalizacja przyrody}

Sherlock Holmes, wysłuchawszy opowieści doktora Mortimera o straszliwym psie szalejącym na bagnach hrabstwa Devonshire i mordującym kolejnych potomków starodawnego rodu Baskervillów, zauważa ze zdziwieniem, że jego rozmówca wierzy w istnienie sił nadprzyrodzonych i że, tym samym, opuścił on (bądź co bądź doktor medycyny i badacz ludzkich czaszek, a więc człowiek nauki) szeregi naturalistów. Odwołuję się do fragmentu znanej powieści Conan Doyle’a dlatego, że dobrze ilustruje znaczenie, które nadawano słowu naturalista jeszcze w drugiej połowie XIX wieku. W rzeczy samej, w wieku XVIII, w epoce Oświecenia, naturalistami zaczęto zwać ludzi (a byli to na ogół filozofowie), którzy sądzili, że wszelkie dające się obserwować zjawiska i wydarzenia zachodzące w świecie materialnej przyrody można wyjaśnić bez odwoływania się do interwencji bytów nadprzyrodzonych. Rejestr spraw podejrzewanych (w tych czasach) o nadprzyrodzony rodowód przyprawia o zawrót głowy i pozwala sobie uświadomić ogrom zadań, których wykonania podejmowali się prekursorzy naturalizmu. Zaliczano do nich nie tylko niezwykłe uzdrowienia, płaczące obrazy itd., lecz także wybuchy wulkanów i trzęsienia ziemi, rzadkie zjawiska astronomiczne, szerzące się epidemie, nieoczekiwane i nagłe zmiany pogody itd., itd. Naturaliści starali się wykazać (często wbrew przeważającej opinii), że wszystkie te zjawiska dają się wytłumaczyć bez odwoływania się do nadprzyrodzonych interwencji. Wystarczyć miała sama materialna przyroda. Ludzie dlatego wierzą w zaświaty i ich bezpośredni 
wpływ na bieg spraw ziemskich - argumentowali naturaliści - że nie posiadają dostatecznej wiedzy o materialnej przyrodzie. Gdy ją posiądą, przekonają się, że prawdziwe przyczyny wszelkich niezwykłych zjawisk i zdarzeń tkwią w materialnej przyrodzie.

Upłynęło kilkaset lat i... stało się. Wybuchy wulkanów i trzęsienia ziemi; zaćmienia słońca, księżyca i przeloty komet; powodzie, epidemie, nieurodzaje itd., itd. - wszystkie te zjawiska zostały znaturalizowane. Odkryto ich naturalne przyczyny i wskazano naturalne skutki, a ich przebieg - co wykazano - okazał się zgodny z prawami przyrody. Otaczający nas świat został odczarowany. (Zauważmy, że dzieła tego dokonali nie filozofowie, ale uczeni przyrodnicy.). Pierwsza naturalizacja - w zasadzie - została ukończona. (Używamy określenia „w zasadzie" dlatego, że w czasach nam współczesnych wielu ludzi wierzy na przykład w nadprzyrodzone pochodzenie niektórych uzdrowień).

\subsection{Naturalizacja umysłu}

Pierwsza naturalizacja miała za swój przedmiot tzw. świat zewnętrzny, tzn. różne niecodzienne i dające się obserwować zjawiska, ale nie dotyczyła samego obserwatora. Naturalizujące przyrodę umysły pozostawały w zasadzie poza zasięgiem naturalizacji. Używam określenia „w zasadzie” dlatego, że w pracach XVIII-wiecznych filozofów pełno jest wzmianek o naturalnym pochodzeniu człowieka i o tym, że gatunek ludzki stanowi nieodłączną część przyrody. Są to jednak wzmianki i ogólne deklaracje. Przyrodnicy i filozofowie, poszukujący naturalnych przyczyn niezwykłych i budzących grozę zjawisk, w ogóle nie brali pod uwagę umysłu. Poznający podmiot-umysł (pozbawiony uprzedzeń i dostatecznie staranny) stanowił niejako Archimedesowy punkt podparcia pierwszej naturalizacji. Był narzędziem naturalizacji, ale jej sam nie podlegał. Współcześni naturaliści dążą do naturalizacji umysłu. Jeżeli dzieło ma zostać ukończone, to poznający umysł ów Archimedesowy punkt podparcia pierwszej naturalizacji - również musi zostać znaturalizowany. Współczesna naturalizacja - będę ją od tej pory często nazywał drugą naturalizacją - ma za swój główny (jeśli nie jedyny) przedmiot umysł. Spróbujmy wstępnie zdać sobie sprawę ze skali i rodzaju trudności towarzyszących drugiej naturalizacji.

\subsubsection{Umysł jako przedmiot naturalizacji}

Przyjrzyjmy się fenomenom, które wydają się ściśle związane z umysłem bądź w pewien sposób zakładają jego istnienie. Wymienimy niektóre z nich tytułem przykładu. Opisując je, posłużę się potocznym, używanym na co dzień językiem, stroniąc, póki co, od filozoficznego żargonu. A więc, po pierwsze, ludzie spostrzegają otaczający ich świat za pośrednictwem wielu zmysłów, czyli - innymi słowy - widzą, słyszą itd., mówiąc krótko, wiedzą, co się wokół nich dzieje; po drugie, ludzie myślą i to o wielu różnych rzeczach, a myśląc „wybiegają” myślą 
w przyszłość i cofają się w przeszłość; żywią przekonania, pragnienia, snują plany, porównują teorie i hipotezy; wyobrażają sobie różne rzeczy i stany rzeczy; istniejące i nieistniejące; zastanawiają się nad prawdziwością twierdzeń, hipotez i teorii itd., itd. Wszystko to są przecież rzeczy oczywiste, ktoś mógłby rzec. W czym problem? Problem polega na tym, że w przyrodniczym obrazie świata, tym razem całego świata, obejmującego również ludzi wraz z ich umysłami, na wszystkie te rzeczy nie ma po prostu miejsca. Byty, którymi zajmują się przyrodnicy, nie widzą ani nie słyszą; nie wybiegają myślą w przyszłość ani nie cofają się w przeszłość; nie tworzą teorii ani nie zastanawiają się nad prawdziwością hipotez itd., itd. Aby zdać sobie z tego sprawę, wystarczy przypomnieć sobie lekcje fizyki lub chemii bądź przejrzeć dowolny podręcznik z tego zakresu.

Współczesny naturalizm często bywa zwany fizykalizmem, a nauka zwana fizyką uchodzi za wzór, do którego winni dążyć naturaliści. W każdym razie pierwsza naturalizacja oznaczała, w gruncie rzeczy, sprowadzenie wymienionych wcześniej fenomenów do procesów czysto fizycznych, czyli takich, którymi zajmują się fizycy. Czy tak samo miałaby również wyglądać druga naturalizacja i czy w ogóle jest ona możliwa? A jeżeli tak, to czy jest ona osiągalna dla ludzi? Czy można znaturalizować naturalistów? A jeżeli tak, to kto miałby tego dokonać? Czy naturalista może znaturalizować samego siebie, a jeżeli tak, to na czym miałoby to polegać? Wszystko to są pytania, które zapewne nasuwają się ludziom zaprawionym w filozoficznych spekulacjach, które, jak sądzę, warto stawiać i na które warto szukać odpowiedzi, zachowując świadomość tego, że są to prawdopodobnie odpowiedzi błędne.

\subsubsection{Pewna osobliwość związana z naturalizacją umysłu}

Osobliwości związanych z naturalizacją umysłu jest wiele. Zwrócimy uwagę na jedną, naszym zdaniem bardzo ważną. Aby ją opisać, wprowadzimy rozróżnienie na naturalizację teoretyczną i naturalizację praktyczną. Nie jestem w stanie podać ścisłych definicji tych pojęć, ale jestem przekonany o ich przydatności. Sądzę ponadto, że ich przydatność będzie się potwierdzać w miarę wprowadzania w krąg rozważań kolejnych zagadnień i tematów. Póki co, ograniczymy się do przykładów, które bardzo wstępnie wyjaśnią, w czym rzecz. Weźmy pod uwagę, np., pralkę automatyczną, samochód, telewizor, komputer lub jakiś inny artefakt wytworzony przez ludzi. Otóż w przypadku tego rodzaju obiektów mielibyśmy do czynienia zarówno z naturalizacją praktyczną, jak i teoretyczną. Praktyczną dlatego, że sami potrafimy je wytwarzać i naprawiać oraz w pełni (lub prawie w pełni) kontrolujemy ich działanie. $Z$ teoretyczną dlatego, że zachowanie (działanie, funkcjonowanie) tych obiektów jest całkowicie wyjaśnione przez znane nam i opisane prawa natury. $Z$ tego rodzaju komfortową sytuacją mamy do czynienia na ogół w przypadku obiektów wytwarzanych przez ludzi. Przykładem naturalizacji teoretycznej, ale już nie praktycznej, byłoby wiele różnych zjawisk przyrody oraz zachowanie wielu różnych obiektów, które nie są naszym dziełem. Trzęsienia ziemi, wybuchy wulkanów, tajfuny itd. 
są znaturalizowane na poziomie teoretycznym, a to dlatego, że umiemy wyjaśnić ich pochodzenie i ich przebieg, ale nie potrafimy ich wywoływać ani nie mamy wpływu na ich przebieg. Innym przykładem byłoby zachowanie słońca; wiele z tego, co się dzieje na słońcu umiemy wyjaśnić, natomiast znikoma jest kontrola i wpływ na to, co dzieje się na słońcu. Zauważmy również, że zarówno naturalizacja teoretyczna, jak i praktyczna są stopniowalne. Rozróżnienia te wydają się istotne z tego względu, że w przypadku ludzi mamy do czynienia z dość osobliwą sytuacją. Otóż na ogół sprawy mają się tak, że naturalizacja teoretyczna poprzedza praktyczną. Wpierw przyrodnicy odkrywają i opisują odpowiednie „siły” natury, a następnie uczymy się je kontrolować i wykorzystywać, a w końcu wytwarzamy odpowiednie artefakty. W przypadku naturalizacji ludzi jest w znacznej mierze odwrotnie. Łatwiej będzie mi je wyszczególnić, gdy skontrastuję je z pierwszą naturalizacją - naturalizacją materialnej przyrody z wyłączeniem umysłu. Otóż, w pierwszym przypadku naturalizacji podlegały rzadko występujące i nieoczekiwane zjawiska, jako to (wyliczmy je raz jeszcze) wybuchy wulkanów, trzęsienia ziemi, epidemie itd. oraz tzw. cuda, jako to płaczące obrazy, niezwykłe uzdrowienia itd. itd. Z czasem olbrzymia większość tych zjawisk została znaturalizowana na poziomie teoretycznym, a niektóre (np. epidemie) - również na poziomie praktycznym. W przypadku naturalizacji ludzi lub naturalizacji umysłu mamy do czynienia z sytuacją odwrotną. Każdego dnia widzimy, słyszymy, wybiegamy myślą w przyszłość, cofamy się w przeszłość, snujemy plany, wątpimy w prawdziwość różnych sądów i teorii, a prawdziwość innych akceptujemy po odpowiednim namyśle itd., itd. Otóż wszystkie te wyliczone zjawiska stanowią naszą codzienną praktykę i w praktyce znakomicie sobie z nimi radzimy, natomiast nie potrafimy ich znaturalizować na poziomie teoretycznym.

Weźmy pod uwagę np. język. Większość dorosłych ludzi włada przynajmniej jednym językiem etnicznym i znakomicie sobie z nim radzi na poziomie praktycznym, zarówno w mowie, jak i piśmie. Posługując się językiem, potrafimy przekazywać swoje myśli innym ludziom, umawiać się z nimi co do pewnych przyszłych zachowań, przekonywać do swoich racji, mówić prawdę lub kłamać, zastraszać i uspokajać itd., itd. Wszystkie te władze - z przyrodniczego, naturalistycznego lub czysto fizycznego punktu widzenia - sprawiają wrażenie magicznych. W przyrodniczym obrazie świata nie ma miejsca na nakłanianie, zastraszanie, umawianie się itd. W przyrodniczym obrazie świata w ogóle nie ma miejsca ani na semantykę, ani na psychologię! Przypuszczam, że olbrzymia większość ludzi nie zajmujących się na co dzień filozofią byłaby bardzo zdziwiona dowiadując się, że ta oto okoliczność, że wypowiadając się mają coś na myśli, że ich wypowiedzi do czegoś się odnoszą, stanowi filozoficzny problem i że ich władze wymagają naturalizacji. Tak dalece zżyliśmy się z pewnymi rodzajami magii, że wydają się nam one całkowicie naturalne, a niektóre spośród nich tak bardzo „nasze”, że ich utrata nie wydaje się możliwa.

Uświadamiamy sobie, że nasze władze i umiejętności są czysto praktyczne i że bynajmniej nie zależą tylko od nas w momencie, gdy coś z naszych niezwykłych umiejętności zaczyna zawodzić. 
Wyobraźmy sobie, że nagle (np. w wyniku wypadku) tracę zdolność „ubierania" myśli w odpowiednie, głośno artykułowane słowa. Mówię, ale nie to, co miałem zamiar i chciałbym powiedzieć. Zdaję sobie z tego sprawę, ale nie jestem w stanie temu zapobiec. Lekarze nie umieją mi pomóc. Utraciłem zdolność, która wydawała się czymś o wiele bardziej oczywistym i o wiele bardziej moim niż umiejętność sięgania ręką po kromkę chleba. Aby sięgnąć po kromkę chleba, niezbędna jest ręka, chleb, odpowiednia odległość itd. Wszystko to są rzeczy (warunki), należące do tzw. zewnętrznego świata i ktoś należący do tego świata (np. jakiś inny człowiek) może usunąć chleb, przytrzymać rękę itd. Natomiast ubieranie myśli w słowa wydaje się zasadniczo czymś innym, gdyż tutaj wszystko zależy ode mnie... I nagle okazuje się, że tracę tę zdolność, że moje chęci nic nie znaczą; że w grę wchodzi skomplikowany, czysto fizyczny obiekt czy system, który się po prostu zepsuł i który w przyszłości jacyś ludzie (eksperci) będą umieli naprawić.

\subsection{Dwie naturalizacje (końcowa uwaga)}

Podstawowa różnica pomiędzy pierwszą a drugą naturalizacją jest następująca: Pierwsza naturalizacja została przeprowadzona przez istoty dysponujące nadprzyrodzonymi władzami i zdolnościami, jako to widzeniem, słyszeniem, myśleniem koncentrującym się na wybranych treściach twierdzeń i stanach rzeczy, bezstronnie obserwujących przyrodę i prowadzących eksperymenty. Przepłoszono w ten sposób z materialnego świata wszystkie siły nadprzyrodzone, cuda sprawiane przez dobre moce i nieszczęścia sprowadzane przez złe, wszystkie magiczne siły i wszystkie duchy... z jednym istotnym wyjątkiem Cała pierwsza naturalizacja została przeprowadzona przez istoty dysponujące, $z$ przyrodniczego punktu widzenia, magicznymi władzami i zdolnościami. Wypłoszyliśmy wszystkie duchy i wszystkie bóstwa oraz całą sprawowaną przez nie magię. Na placu boju pozostały tylko ludzkie bóstwa i sprawowana przez nie magia. Jeżeli dzieło naturalizacji ma zostać zakończone, trzeba dokonać autonaturalizacji, trzeba znaturalizować naturalistów.

\section{Dwie rewolucje}

Kamieniem węgielnym współczesnej naturalizacji - naturalizacji umysłu - nie są filozoficzne argumenty, ale rozwój nauk szczegółowych, a w szczególności rozwój nauk biologicznych oraz powstanie i rozwój szeregu dyscyplin, składających się na tzw. sztuczną inteligencję. Rozwój wiedzy oraz idący z nią w parze przyrost umiejętności praktycznych jest tak gwałtowny, że zwykło się mówić o dwóch rewolucjach: rewolucji w naukach biologicznych i rewolucji informatycznej. Dualizmu ciała i duszy, substancji rozciągłej i myślącej nie uśmiercono osinowym 
kołem filozoficznych racji, ale stało się to za sprawą przyrostu wiedzy szczegółowej. Filozoficzne koncepty i teorie, niekiedy dziwaczne, próbują nadążyć za mapami mózgu i „myślącymi” artefaktami. Spróbujmy wstępnie i, póki co, bardzo ogólnie odnaleźć się w tej nowej i szybko się zmieniającej sytuacji poznawczej.

\subsection{Rewolucja w naukach biologicznych}

Filozofowie na szczęście nie muszą wnikać w szczegóły. Wystarczy, że szkicują ogólny obraz. Skorzystajmy z tego przywileju i skupmy się na sprawach kluczowych z interesującego nas punktu widzenia. Otóż nauki biologiczne przekonują nas (filozofów i laików - bez wyjątku) w coraz większym stopniu i w sposób pozostawiający coraz mniej miejsca na wątpliwości o dwóch rzeczach.

Po pierwsze o tym, że w ciałach żywych organizmów ( $w$ tym w ciałach organizmów ludzkich) nie dzieje się nic nadzwyczajnego. Rzeczy, procesy, wydarzenia..., które tam znajdujemy podlegają znanym skądinąd i odkrytym wcześniej prawidłowościom. Mówiąc krótko, nie dzieje się tam nic takiego, co zdumiewałoby fizyka czy chemika i zmuszało do wprowadzenia nowych czy też korekty starych, znanych praw i zasad. Innymi słowy, wszystko to, co wydarza się we wnętrzach ludzkich organizmów, włączając $w$ to centralny układ nerwowy wraz z mózgiem, wydaje się być nieodrodną częścią materialnej przyrody. Żadnych fluidów, eterów, sił życiowych..., żadnych śladów ingerencji spoza znanego i badanego przez przyrodników świata. Żadnych cudów! Współcześni naturaliści zwykli wyrażać to mówiąc, że biologia jest w zasadzie redukowalna do fizyki!

Po drugie, związek pomiędzy szeroko pojmowaną sferą psychiczności a tym, co zachodzi w ciałach ludzkich organizmów jest o wiele bardziej fundamentalny, ścisły, chciało by się rzec dosłowny niż mogłoby się wydawać jakiś 50 czy choćby 10 lat temu. Próżno by o tym pisać, gdyż nieomal każdy dzień przynosi nowe, często zaskakujące odkrycia. Współcześni naturaliści zwykli wyrażać tę zależność, powiadając, że to, co psychiczne superweniuje na tym, co fizyczne. Pojęciu superweniencji i związanych z nią problemów poświęcimy w przyszłości więcej miejsca. Tymczasem zastąpmy słowo „superweniencja” bardziej swojskim słowem „determinacja” i zauważmy, że wiedza gromadzona przez nauki biologiczne skłania ku przeświadczeniu, że to, co psychiczne, świadome, mentalne... jest w pewien szczególny sposób determinowane przez to, co fizyczne. Natura i rodzaj tej determinacji to otwarty filozoficzny problem i przedmiot zażartych sporów.

Pozostając na poziomie ogólników, poczyńmy jeszcze kilka prostych spostrzeżeń. Otóż, skoro ludzkie ciała i wszystko to, co się w nich wydarza stanowi nieodrodną część materialnej przyrody, to poznając coraz lepiej materialną przyrodę poznajemy zarazem i coraz lepiej rozumiemy procesy zachodzące w ludzkich ciałach. Fizyka i chemia w coraz większym stopniu stanowią bezpośrednie zaplecze nauk biologicznych Zagadki i dylematy trapiące filozofów umysłu są, być może, w jakiejś mierze zagadkami i dylematami niepokojącymi współczesnych fizyków. 
Skoro ludzkie ciała i wszystkie zachodzące w nich procesy są całkowicie naturalne, to na to, co się w nich dzieje można wpływać na wiele różnych sposobów - sposobów znanych skądinąd i przebadanych w warunkach laboratoryjnych. Mamy tu na myśli rozliczne lekarstwa, a w szczególności tzw. leki psychotropowe. Wpływając wybiórczo na procesy chemiczne zachodzące w ludzkich organizmach, wpływamy zarazem na szeroko pojmowaną sferę duchowości. Istnieją leki podnoszące i obniżające nastroje; wygaszające świadomość w przeciągu kilku sekund i umożliwiające lepszą koncentrację i pracę bez wytchnienia przez wiele godzin; niektóre substancje potrafią zmienić całkowicie system przekonań i system wartości (na jakiś czas lub trwale), inne generują urojenia i omamy itd., itd. Wszystko to są rzeczy dobrze znane, ale warto je sobie uświadomić w interesującym nas kontekście. Chemia ludzkiego organizmu wpływa bezpośrednio na sferę zarezerwowaną przez tradycyjne myślenie dla „pasji duszy”, a z kolei chemia ludzkiego organizmu jest zwykłą chemią, badaną i odtwarzalną w retortach i kolbach.

Biolodzy odkryli, że ciała ludzi składają się z mniejszych części, pełniących określone funkcje, te $z$ jeszcze mniejszych, aż wreszcie schodzimy na poziom komórek, podstawowego budulca żywych organizmów. Komórki wszelako też mają swoją budowę i można je dzielić w dalszym ciągu..., aż wreszcie sięgniemy poziomu atomów i molekuł, poziomu właściwego całej materialnej przyrodzie i badanego przez fizyków. Żadnych nadzwyczajności; żadnych tajemnic.

Funkcje wielu organów poznano w stopniu umożliwiającym ich wymianę na inne, lepsze, mniej zużyte. Wymienia się w ten sposób serca, nerki, wątroby, przetacza krew itd., itd., a niektórzy medycy-chirurdzy przewidują, że w najbliższej przyszłości będzie możliwa wymiana całych korpusów (np. w przypadku ich nieodwracalnego uszkodzenia w wypadkach drogowych).

Przejdźmy do ostatniej rzeczy, być może najważniejszej. Jak to się dzieje, że umieszczamy w takiej samej glebie dwa bardzo podobne i niewielkie obiekty (chodzi o nasiona) i po pewnym czasie z jednego wyrasta róża, a z drugiego dąb; i jak to się dzieje, że z bardzo podobnych, a dla laika takich samych obiektów (chodzi o zygoty) po pewnym czasie formuje się już to tygrys, już to krowa, już to antylopa itd., itd. Przecież w tych maleńkich fragmentach materii nie widać (gołym okiem czy pod mikroskopem) nawet w śladowej postaci czy to róży, czy dębu, czy tygrysa. Jak to się dzieje i co o tym decyduje? Najwyraźniej - spekulowano - w każdym z tych przypadków istnieje jakiś plan czy też forma (jak powiedziałby Arystoteles), który „bezwolna materia” musi realizować. Biolodzy odkryli ten plan, poznali zasady jego działania, opisali go i... opanowują trudną sztukę ingerowania w jego mechanizmy. Ulepszanie już istniejących gatunków (ich genetyczne modyfikowanie) i wytwarzanie zupełnie nowych (poprzez mieszanie materiału genetycznego) leży już nie tylko w zasięgu wyobraźni, ale staje się w coraz większym stopniu i w coraz szerszym zakresie po prostu rzeczywistością. Naukowcy-genetycy zapowiadają wskrzeszenie wymarłych gatunków (jeśli tylko zachował się genom, to czemu nie?) i obiecują realizację odwiecznego marzenia ludzkości - indywidualnej nieśmiertelności. Jeśli nawet nie wszystkie z tych przewidywań są trafne i nie wszystkie obietnice zostaną spełnione, to nie ulega wątpliwości, że rozpoczął się siódmy dzień stworzenia! 
Nasze dywagacje na temat osiągnięć nauk biologicznych zachęcają do wybiegania myślą w przyszłość i prób wyobrażenia sobie świata za lat dziesięć lub pięćdziesiąt. Ponieważ jesteśmy filozofami i kochamy spekulacje, z niekłamaną przyjemnością snulibyśmy opowieści o żyrafo-słoniach i ludziach dysponujących siłą niedźwiedzia, wzrokiem orła i chyżością antylopy. W tej pracy chcemy jednak twardo stąpać po ziemi i zamierzamy dawkować fantazje (których i tak nie braknie) z aptekarską powściągliwością. Jeżeli jednak ktoś chciałby się „wybrać w przyszłość", to koniecznie musiałby uwzględnić jeszcze jeden czynnik, a mianowicie rewolucję informatyczno-cybernetyczną. Jej wpływ na przekonania dotyczące umysłu i podkopanie tradycyjnego (czyli substancjalnego) dualizmu jest co najmniej równie istotny, jak osiągnięcia nauk biologicznych. Nim zajmiemy się tą sprawą w sposób systematyczny, zauważmy co następuje.

Naturalnym środowiskiem współczesnych ludzi nie są już lasy, pola, łąki, jeziora, góry i rzeki, a nawet nie są nim miasta, domy, szafy, sztućce, kufry i kredensy. Naturalnym środowiskiem współczesnych ludzi (a dotyczy to zwłaszcza ludzi młodych) są w coraz większym stopniu artefakty, których istnienie i sposób funkcjonowania zawdzięczamy rewolucji informatyczno-cybernetycznej (połączonym wysiłkom fizyków, chemików, informatyków, inżynierów, techników itd., itd.). Jeżeli kogoś razi określenie „środowisko naturalne” na opisanie artefaktów, to wyjaśniam, że mam tu na myśli po prostu to, że wielu ludzi (a ich liczba szybko wzrasta) spędza większość swojego aktywnego i świadomego życia, stukając w klawiaturę i wypatrując na ekranie efektów swojej działalności. Jeżeli jedną z pierwszych rzeczy, jakie małe dziecko bierze do ręki jest telefon komórkowy, a umiejętność połączenia się z ciocią przez Skype'a poprzedza naukę posługiwania się łyżką, to klawiatury, ekrany, Iphony i joysticki stanowią jego środowisko naturalne. W nazywaniu wszystkich tych cudownych tworów ludzkiej nauki i techniki naturalnym środowiskiem tkwi, rzecz jasna, pewna retoryczna przesada. Ludziom, którzy nie odchodzą od klawiatury nawet w nocy, w dalszym ciągu do utrzymania się przy życiu niezbędne są pewne ilości pokarmu, wody i powietrza. Żyjemy w świecie artefaktów i działamy za ich pośrednictwem, ale nasze serca tłoczą krew, a żołądki trawią pokarmy w taki sam sposób, w jaki robiły to serca i żołądki naszych praprzodków. Otaczające nas gadżety (bez których już nie potrafimy się obejść) są nieustannie doskonalone, a zepsute można łatwo naprawić. Nasze serca, płuca i wątroby..., odziedziczone po praprzodkach, nie doskonalą się ani trochę, a zużyte są bardzo trudne do "naprawy”. Nasze oczy wypatrują na monitorach skutków działalności palców na klawiaturach, ale są równie niedoskonałe i równie łatwo się męczą, jak oczy ludzi polujących na mamuty. A poza tym starzejemy się. Biologiczny zegar tyka nieustannie i każdy miniony dzień zbliża nas do śmierci. A tak w ogóle, to żeby istnieć, trzeba bez przerwy oddychać. Przecież to straszne! Czy nie ma na to żadnej rady?

Skoro przyroda jest jednością i w naszych ciałach zachodzą całkowicie naturalne (tzn. znane skądinąd) fizykochemiczne procesy, a nasze ciała, tak jak i wytworzone przez nas artefakty, składają się z mniejszych części, pełniących określone funkcje, to poznawszy dostatecznie dobrze te funkcje, można byłoby wymieniać zużyte biologiczne organy na wytworzone fabrycznie artefakty, pełnią- 
ce równie dobrze (a z czasem może i lepiej) te same funkcje. W jakiejś mierze proces taki już się dokonuje. Istnieją sztuczne serca, nerki wątroby..., a nawet sztuczne ręce i nogi. Organy te (na razie) nie są równie sprawne jak ich biologiczne pierwowzory, ale postęp jest bardzo szybki i dokonuje się na naszych oczach. Sztuczne ręce np. nie przypominają kikutów znanych z filmów o piratach, ale są to zaawansowane pod względem technicznym i wysoce wyspecjalizowane artefakty, których dłonie wykonują polecenia płynące z mózgu (lub umysłu), wyposażone są w „zmysł dotyku” i, w niektórych przynajmniej sytuacjach, są bardziej przydatne niż biologiczne odpowiedniki (można za ich pomocą wyciągnąć gwóźdź ze ściany i kręcić dłonią, jeśli jest taka potrzeba lub życzenie, wokół poziomej osi przedramienia).

Skoro jednak można wymienić ręce i nogi, zachowując w nich zdolność „czucia" (twarde, miękkie, szorstkie, gładkie, zimne, gorące itd.) oraz możność działania za ich pośrednictwem, to naturalna jest następująca sugestia. Do czego są nam właściwie potrzebne sztuczne serca, nerki, wątroby, płuca itd.? Czy nie prościej (i lepiej) byłoby „podłączyć” mózg bezpośrednio do jakiegoś super-artefaktu, wyposażonego w zmysły (z czasem zapewne znacznie doskonalsze niż te, w które wyposażyła nas natura) i zapewniającego nam zdolność działania? Wyzwalając się spod tyranii oddychania, trawienia itd., zachowalibyśmy wszystko to, co istotne - możność działania i umysł.

A co z mózgiem, tym „siedliskiem duszy”? Czy nie można byłoby wyzwolić się również od tyranii neuronów, synaps i transmiterów i całkowicie porzucić biologiczną skórę, zachowując przy tym całe bogactwo naszego życia duchowego? Jeżeli to, co mentalne jest determinowane przez to, co fizyczne, to "taka operacja" byłaby w zasadzie możliwa. Żyjący i działający ludzki mózg posiada jednak tak wiele różnych fizycznych własności... Zapewne nie wszystkie są istotne dla zachowania naszego mentalnego bytowania w dotychczasowym kształcie. Nim spróbujemy odnieść się do tej wątpliwości, musimy spojrzeć na wszystkie te sprawy z innego jeszcze, równie ważnego, punktu widzenia.

\subsection{Rewolucja informatyczno-cybernetyczna}

Rozpoczynając zajęcia poświęcone wpływowi rewolucji informatyczno-cybernetycznej (w naukach biologicznych oraz informatycznej) na przekonania dotyczące umysłu, zwykłem rutynowo zadawać kilka pytań. Oto one:

(1) Czy możliwe jest utworzenie obrazu z dwóch drutów i barwnych nici?

(2) Czy z początkujących szachistów można utworzyć zespół wygrywający nawet z najsilniejszymi graczami? A czy można taki zespół utworzyć z kręcących się kółek?

(3) Czy z ludzi nieznających chińskiego można utworzyć zespół porozumiewający się w tym języku z Chińczykami? Czy zespół taki rzeczywiście będzie rozumiał język chiński? 
(4) Czy z ludzi niewidomych od urodzenia (lub obiektów nie posiadających wrażeń wzrokowych) można utworzyć kogoś (lub coś), kto (lub co) będzie posiadał (lub posiadało) normalne wrażenia wzrokowe?

Odpowiedź na pierwsze pytanie jest oczywista. Wszyscy - z doświadczenia - wiedzą, że jest to możliwe. Odpowiedzi na drugie pytanie były zróżnicowane. Studenci kierunków humanistycznych odpowiadali w większości, że nie; studenci informatyki, że tak. Trzecie pytanie wywoływało ostre spory - także wśród studentów informatyki. Uczestnicy dyskusji odwoływali się do pojęcie rozumienia i odczuwali potrzebę wprowadzenia rozróżnienia na gramatykę i semantykę. Wielu studentów informatyki jest skłonnych sądzić, że tym razem niezbędny jest ktoś, kto rozumie język, kto chwyta znaczenia. Na czwarte pytanie wszyscy odpowiadali tak samo: Oczywiście, że nie. Ani z ludzi niewidomych od urodzenia, ani ze „ślepych” obiektów nie sposób utworzyć całości posiadającej normalne wrażenia wzrokowe. Konieczne jest, aby choć jeden spośród nich coś widział; chociaż trochę! Dlaczego jednak? Otóż sądzę, że udzielający odpowiedzi na ostatnie pytanie znaleźli się pod przemożnym działaniem pewnego przeświadczenia lub mitu. Przeświadczenia, które z największą siłą oddziałało w przypadku ostatniego pytania i dlatego wyróżniliśmy je pogrubionym drukiem.

Mówienie o przeświadczeniu lub micie jest jednak mylące. Rzecz, którą mam na uwadze, to raczej odruch niż teza o dającej się wyrazić słowami treści. Ostatnie słowo wyróżnione kursywą jest chyba najwłaściwsze. Nie umiemy nadać odruchom postaci twierdzeń, ale za to potrafimy wskazać okoliczności, w których zachodzą. Rozpocznę od tego, co potrafię, a więc od wskazania typowych okoliczności, w których interesujący nas odruch dochodzi do skutku. W dalszym ciągu, odwołując się do zajmującego nas tutaj zjawiska, będę mówił o odruchowym szukaniu podmiotu. Jest ono, moim zdaniem, jednym z filarów intuicyjnej wiary w realność podmiotu-ducha.

\subsubsection{Szukanie podmiotu i rewolucja informatyczno-cybernetyczna}

Aby zilustrować funkcjonowanie interesującego nas mechanizmu, odwołam się do wydarzeń, które zaszły w drugiej połowie XVIII wieku. Będzie to miało podwójną zaletę - zwróci uwagę na jego uniwersalność i zawodność.

Otóż istniejące współcześnie, odpowiednio zaprogramowane komputery nie są bynajmniej pierwszymi artefaktami, grywającymi w szachy. W roku 1769 baron Wolfgang von Kempelen (radca dworu cesarzowej Marii Teresy) zademonstrował - wpierw w swym rodzinnym mieście Bratysławie, a następnie w Wiedniu - mechanicznego gracza w szachy. Cała konstrukcja była wielkości dużego biurka z wmontowaną weń szachownicą, przy której siedział automatyczny gracz - figurka człowieka, ubrana w tradycyjny turecki strój. Już pierwsze pokazy wzbudziły nie lada sensację. „Turek” wygrywał nawet z najlepszymi graczami. 
Historia automatu była długa i burzliwa. Występował on w wielu miastach i stolicach Europy ( $w$ drodze do Petersburga był prawdopodobnie demonstrowany także w Warszawie) i grywał z wieloma znanymi szachistami oraz sławnymi ludźmi (spośród trzystu partii, co do których zachowały się świadectwa, automat przegrał zaledwie sześć). W roku 1809, w pałacu Schönbrunn w Wiedniu, automat miał zaszczyt grać z samym Napoleonem. Cesarz w pewnym momencie wykonał (celowo) niedozwolony ruch. „Turek” poprawił figurę. W odpowiedzi na to - znów nieprawidłowe zagranie. Automat ponownie skorygował błąd. Za trzecim razem "Turek" zrzucił bierki na podłogę. Napoleon miał być z siebie bardzo zadowolony - udało mu się zdenerwować maszynę! Tyle historii i anegdot. Przejdźmy do interesującej nas tutaj kwestii.

Otóż, poza nielicznymi wyjątkami, widzowie byli spontanicznie, nieomal odruchowo przeświadczeni, że mają do czynienia z mistyfikacją. Podziwiano nie tyle sam automat, ile „zręczność konstruktora”, który potrafił w udany sposób zamaskować działalność właściwego gracza-człowieka. Aby nie być gołosłownym, pozwolę sobie przytoczyć fragment sprawozdania reporterskiego, datowanego 13 października 1784 r., które ukazało się w jednym z zeszytów warszawskiego „Pamiętnika Historyczno-Politycznego” (Giżycki 1984). Autor, wysłannik magazynu na targi lipskie (gdzie akurat odbywała się prezentacja automatu) pisze:

[...] łatwo się można domyśleć, że to pan Anthon [demonstrator, przyp. autora] dyryguje owemi okolicznościami, których jest tak wiele w tej grze trudnej, [...] ale jakże on to wszystko powoduje, że tego nie można dostrzec? Jak on wpływa w machinę, iż jest ona posłuszna na wszystkie jego dobrowolne poruszenia? Dla nas wszystkich [...] jest to rzeczą niepojętą [...].

Przejdźmy obecnie do głównej myśli tego paragrafu. Otóż jestem zdania, że tzw. dualizm substancjalny (mogący przybrać zresztą wiele różnych form) jest w gruncie rzeczy teorią zdrowego rozsądku i powstaje spontanicznie. Teoria ta czerpie swą siłę z dwóch różnych źródeł. Jednym z nich jest to, co zwykło się nazywać życiem wewnętrznym lub subiektywnym punktem widzenia, drugim - tzw. uprzywilejowany dostęp do tej sfery. Są to sprawy, którym w dalszych rozdziałach poświęcimy nieco więcej miejsca. Tutaj jednak zajmuje nas co innego. Sądzę, że równie ważnym filarem dualizmu było (i w jakiejś mierze jest $\mathrm{w}$ dalszym ciągu) niesłychanie silne, intuicyjne, wręcz odruchowe przekonanie, że pewnych rzeczy nie można uzyskać metodami systemowo-inżynierskimi. Przekonanie to ma w sobie coś z oczywistości, której - wydawałoby się - nie sposób zaprzeczyć.

Weźmy pod uwagę pewien obraz, potnijmy go na małe kwadraciki i zmieszajmy. Złożenie kwadracików ponownie w obraz mogłoby zająć nam bardzo dużo czasu, a nawet mogłoby się okazać (gdyby obraz był duży i skomplikowany) zadaniem przekraczającym nasze możliwości. Pomimo wszelkich trudności, na jakie moglibyśmy się natknąć próbując złożyć obraz, jedno byłoby jasne: zadanie jest w zasadzie wykonalne! Jest to przykład sytuacji, w której tzw. myślenie systemowe nie nastręcza żadnych trudności teoretycznych, a nawet narzuca się jako samooczywiste. Wszyscy wiedzą, że domy zbudowane są z cegieł, a obraz można rozbić na małe barwne kwadraciki. Widząc dom lub gotowy obraz, poszukujemy, co prawda, autora, ale nie mielibyśmy specjalnych kłopotów (z wyobraź- 
nią), gdyby proszono nas, abyśmy puścili wodze fantazji i (na próbę) pomyśleli, że cegły lub barwne kwadraciki same (przez przypadek lub w wyniku działanie ślepych sił natury) złożyły się w dom lub obraz.. Gdyby pan Kempelen, zamiast maszyny do gry w szachy, skonstruował maszynę do tworzenia obrazów z barwnych kwadracików, niewielu podejrzewałoby mistyfikację; nie widziano by potrzeby uciekania się do oszustwa. Czyż nie jest jasne, że dom tkwi już w cegłach, a obraz w barwnych kwadracikach?!

Powróćmy do szachów. Niech mistrz świata rozegra pięć partii z początkującym szachistą. Przecież to nie ma sensu, chciałoby się rzec. Mistrz świata wygra za każdym razem. Wyrównajmy więc nieco szanse. Niech dwóch początkujących graczy zmierzy się z mistrzem świata. Niech się naradzają i wspólnie planują posunięcia. Nic to nie zmieni. Znowu przegrają każdą partię. Więc może trzech, czterech lub dziesięciu? Ależ to jakiś absurd. Wszystko jedno, czy będzie ich dwóch czy miliard. I tak zawsze przegrają. Liczba nie odgrywa tu żadnej roli. Aby wygrać z mistrzem świata, trzeba dysponować pojedynczym genialnym umysłem. Czyż nie jest to oczywiste?!

Bieg myśli przedstawiony w poprzednim akapicie istotnie ma w sobie coś z oczywistości. W każdym razie takiemu właśnie odruchowi poddaje się większość zagadniętych o to znienacka studentów. "Oczywistość”, o którą tu idzie, łatwo można byłoby uczynić jeszcze bardziej oczywistą. Niech z mistrzem świata zmierzy się (dowolnie liczny) zespół ludzi, z których żaden w ogóle nie potrafi grać w szachy. Cóż wtedy? Muszą przegrać! Muszą przegrać, gdyż nikt nie jest w stanie wykrzesać $z$ tych ludzi więcej niż w nich tkwi. Z barwnych kwadracików można złożyć obraz, gdyż w każdym z nich jest już "trochę obrazu”. Z ludzi nie potrafiących grać w szachy nie można złożyć szachisty, gdyż w żadnym z nich nie ma ani trochę tej umiejętności. Z pustego i Salomon nie naleje, chciałoby się rzec.

Wejdźmy ponownie „w skórę” reportera „Pamiętnika Historyczno-Politycznego". Obecnie możemy lepiej zrozumieć jego sytuację poznawczą. Demonstrator automatu co pewien czas otwierał skrzynię i osobiście nakręcał maszynę. W tym momencie oczom zdumionej publiczności ukazywał się wewnętrzny mechanizm. Był on przesadnie skomplikowany i obliczony na wizualne efekty (jego zadaniem było odciągnięcie uwagi od gracza-człowieka, ukrytego w innym miejscu). Kręciły się tam różnej wielkości koła zębate, tryby, dźwignie itd. Jakże w tej sytuacji nie domniemywać oszustwa?! O ileż "głupsze” są koła zębate od najgłupszego nawet człowieka. Przecież nic nie potrafią. Kręcą się tylko w lewo lub w prawo. To niemożliwe, żeby kręcące się koła zębate tak dobrze grały w szachy. Gdzieś w środku musi być ukryty człowiek!

Rzeczywiście, w środku ukryty był człowiek. Sekret polegał na tym, że wewnątrz skrzyni z szachownicą, przy której siedział „Turek”, ukryty był gracz kierujący mechanizmem aparatury. Schowany w środku człowiek nie był widoczny nawet po otwarciu znajdujących się z przodu drzwiczek. Złudzenie pustki wewnątrz pudła stwarzały poustawiane pod odpowiednimi kątami zwierciadła. Nikt nie zdołał go znaleźć, gdyż nikt nie przeszukiwał dokładnie automatu; pokazy odbywały się w salonach, wśród ludzi dobrze wychowanych. 
Zmieńmy nieco historię i załóżmy, że ktoś przeszukuje dokładnie automat i odnajduje ukrytego wewnątrz człowieka. Skompromitowałoby to zapewne pana Kempelena, ale w niczym nie zmieniłoby istoty rzeczy. Załóżmy bowiem, że pewien dociekliwy filozof nie czuje się w pełni usatysfakcjonowany i uważa, że tajemnica nie została bynajmniej wyjaśniona. Postanawia szukać dalej i zagląda do wnętrza głowy ludzkiego gracza. To, co by tam „ujrzał”, utwierdziłoby go tylko w przekonaniu, że nie-filozofowie są jak małe dzieci, które widząc grającą w szachy zabawkę nie potrafią sobie tego wyjaśnić w inny sposób, jak tylko przyjmując, że w środku znajduje się inna, mniejsza zabawka. (W podobny sposób Arystoteles wyśmiewał się z Demokryta.). Przecież to, co „dzieje się" w głowie ludzkiego gracza wcale lepiej nie wyjaśnia umiejętności gry w szachy niż kręcące się tryby. Zachodzą tam procesy chemiczne i elektryczne. Procesy te są jednak równie "głupie” jak kręcące się tryby i głupsze od najgłupszego nawet człowieka. Skoro z kiepskich szachistów nie sposób złożyć jednego dobrego, tym bardziej - z procesów chemicznych i elektrycznych. Sprawdziliśmy już wszystko nadzwyczaj dokładnie. We wnętrzu maszyny mechanicznej, złożonej z zębatych kół, odkryliśmy inną, mniejszą maszynę, złożoną z neuronów. To, co zachodzi w maszynie neuronowej, wcale jednak lepiej nie tłumaczy gry w szachy niż kręcące się tryby - mógłby rzec nasz filozof. $Z$ drugiej strony nie ulega wątpliwości, że mamy do czynienia z fenomenem gry w szachy. Co dalej? No cóż, nie ma tu dużego wyboru. Trzeba postulować istnienie jeszcze jednego bytu. Ktoś przecież musi grać w szachy! Nie może to być jednak kolejna maszyna; niczego by to przecież nie zmieniło itd. Właściwy gracz, ten który naprawdę przewiduje, planuje, myśli..., musi być zupełnie innej natury. Można byłoby go nazwać substancją przewidującą, planującą, myślącą...

Ludzie od dawien dawna potrafili organizować pracę fizyczną. Zadanie, którego nie potrafi wykonać żaden pojedynczy człowiek, może zostać z powodzeniem wykonane przez zespół złożony z dwóch, pięciu lub sześciu ludzi. Jeden człowiek nie wniesie fortepianu na trzecie piętro. Zespół złożony z kilkorga ludzi poradzi już sobie z tym zadaniem. Jest (i było od niepamiętnych czasów) oczywiste, że pracę fizyczną można dodawać i zwielokrotniać, osiągając tą drogą zadziwiające efekty. Gdy spotykamy pałac zadziwiających rozmiarów, to nie dziwi nas to ani trochę. Cóż z tego, że nie zdołałby go zbudować jeden człowiek? To, czego nie potrafi jeden, potrafi wielu.

Ludzie od dawien dawna „wiedzieli” również, że istnieją bariery, których nie można przekroczyć. Ducha, substancji myślącej, niematerialnego umysłu doszukujemy się na ogół tam, gdzie zawodzi myślenie systemowe, gdzie w żaden sposób nie potrafimy wyobrazić sobie, jak z elementów nie posiadających pewnej własności lub dyspozycji można byłoby złożyć całość posiadającą już tę własność. Można byłoby powiedzieć, że tym silniej odczuwamy potrzebę podmiotu, duszy, substancji myślącej itd., im trudniej przychodzi nam sobie wyobrazić, że z obiektów nie posiadających pewnej własności, dyspozycji, władzy można byłoby utworzyć całość posiadającą już tę własność, dyspozycję, władzę. Jakże można byłoby z kiepskich szachistów „złożyć” jednego dobrego, z ludzi nieznających np. języka francuskiego kogoś lub coś, co będzie ów język rozumieć, ze 
ślepców widzącego? Przecież to niemożliwe! A skoro jest to niemożliwe, to istnieje przepaść - ontologiczna przepaść - pomiędzy tym, co myślące, rozumiejące, widzące... a światem maszyn, systemów składających się z mniejszych części, wszystko jedno, czy są to kręcące się kółka, czy neurony...

Doniosłość rewolucji komputerowej, jej przełomowość leży w tym, że udowodniono (i to ponad wszelką wątpliwość, bo pokazano, jak się to robi, ba - zrobiono to), że do „myślenia” (a w każdym razie do osiągania rzeczy, które uchodziły za możliwe do osiągnięcia dzięki myśleniu) nie jest potrzebny żaden umysł, żadna specjalna a tajemnicza substancja, wystarczą najbanalniejsze, czysto fizyczne wydarzenia, w szczególności mogłyby to nawet być (jak w maszynie Kempelena) kręcące się zębate kółka. W rzeczy samej, to, co w XVIII czy XIX wieku mogło istnieć tylko dzięki mistyfikacji, stało się faktem. Rewolucja informatyczno-cybernetyczna skuteczniej niż cokolwiek innego zasypała różnicę pomiędzy tym, co fizyczne, a tym, co umysłowe. W liczących ponad 2500 lat dziejach spekulacji dotyczących natury umysłu rozpoczęła się zupełnie nowa era.

\section{Model do składania}

Odwołam się jeszcze raz do swoich doświadczeń z zajęć ze studentami. Otóż studenci dość szybko dają się przekonać, że z kręcących się kółek można w zasadzie złożyć genialnego szachistę. Jak jednak ze ślepców „zrobić” kogoś, kto miałby takie wrażenia wzrokowe, które miewają ludzie, spoglądając na świeżą trawę lub dojrzałe cytryny? Wielu ludziom, w pierwszej chwili, wydaje się to zupełnie niemożliwe.

Nie trzeba wiele, aby studenci zmienili zdanie. Wystarczy zaproponować następujący eksperyment myślowy.

- Czy ze ślepców można „zrobić” widzącego, a z głuchych słyszącego? Czemu nie? Wyobraźmy sobie pewnego człowieka. Niech widzi i słyszy. Następnie rozkładajmy go (w myśli) na części..., tak długo, aż dojdziemy do obiektów głuchych i ślepych, aż do neuronów i komórek. Każdy przyzna, że jest to możliwe i każdy przyzna, że pojedyncze komórki nie widzą i nie słyszą. Pierwsza faza eksperymentu zakończona. A teraz połączmy wszystko tak, jak przedtem (wyobraźmy sobie, że umiemy to zrobić). Tak, aby znowu powstał ów człowiek. Pytanie moje brzmi: Czy będzie on widział i słyszał?

- Oczywiście, że tak. Przecież wszystko jest tak, jak przedtem! - odpowiadali słuchacze.

Ta jednozgodność opinii oraz siła, z jaką była wypowiadana i podtrzymywana, przyznaję, nieco mnie zaskoczyła. I to z dwóch powodów. Po pierwsze dlatego, że odpowiedź na pytanie o naturę umysłu, okazuje się w znacznej mierze zależy od kontekstu w ramach którego formułuje się takie pytanie). A po drugie dlatego, 
że wynika z niej, że w pewnym sensie, a przynajmniej w pewnych kontekstach, studenci (wszystko jedno, czy są to informatycy, czy humaniści) przyznają, że Człowiek, to model do składania i można go złożyć z mniejszych części! (Choć, oczywiście, wcale to nie oznacza, że - zdaniem studentów - ludzi można „składać” z czegokolwiek, np. z kręcących się kółek). Co sprawia, że przekonanie to jest tak powszechne i niezachwiane (a w każdym razie jest takie wśród moich studentów)?

Eksperyment myślowy, który przedstawiłem, jest w końcu niesłychanie prosty i łatwy do zaprojektowania. Przecież ludzie (w tym, oczywiście, Kartezjusz) od dawna wiedzieli, że ciała ludzi są podzielne, że złożone są z mniejszych części, że $w$ zasadzie można je rozkładać i (na powrót) składać. Tego rodzaju eksperymenty myślowe nie miały jednak żadnego wpływu na ich przekonania. Dlaczego dla współczesnych mi ludzi są rozstrzygające? Kiedy i dlaczego nastąpił ów przełom w myśleniu o człowieku?

Chciałbym w tym miejscu odwołać się do pewnego wspomnienia. Około 40 lat temu, gdzieś w latach siedemdziesiątych, brałem udział w seminarium z filozofii umysłu. Zajęcia były poświęcone rozpatrywaniu relacji zachodzącej pomiędzy ciałem a umysłem. Jedną z teorii, którą prezentowano był epifenomenalizm. Wedle tej koncepcji, fenomeny mentalne - myśli, wrażenia itd. - są czymś innym niż fizyczne stany czy procesy zachodzące w ciałach żywych organizmów i są realne (tzn. rzeczywiście się pojawiają), z tym, że nie posiadają żadnych mocy przyczynowych - ich obecność nie ma żadnego wpływu na bieg materialnej przyrody. Życie wewnętrzne lub psychiczne jest w całości powodowane i determinowane przez procesy zachodzące $w$ ciele, ale samo nie wywiera na owe procesy żadnego wpływu. Aby polepszyć rozumienie tego stanowiska, prowadzący zajęcia posługiwał się porównaniami. Umysł ma się do ciała tak, jak para uchodząca z parowozu do pracującego wewnątrz silnika; lub jak iskry do tokarki. Strumień świadomości to jakby cień, rzucany przez funkcjonujące ludzkie mózgi. Historii ciała towarzyszy równoległa historia wydarzeń mentalnych. Są one jednak (podobnie jak ruchy i kształty cienia) całkowicie determinowane przez to, co dzieje się z ciałem i same $z$ kolei nie są w stanie wpłynąć $w$ jakikolwiek sposób na to, co przydarza się ciału itd., itd. Pamiętam, że teorię tę skwitowano wówczas stwierdzeniem, że jest to wulgarny fizjologizm. Diagnoza ta nie wzbudziła żadnego sprzeciwu. Wydała się naturalna i dobrze uzasadniona. Toż to wyuzdany spirytualizm - powiada wielu współczesnych filozofów umysłu. Zestawienie wyrażeń wyróżnionych kursywą nieźle ilustruje drogę, jaką przebyły przekonania dotyczące umysłu i człowieka w przeciągu ostatnich kilkudziesięciu lat. Historyk idei wiele się może nauczyć, śledząc historię ocen i epitetów.

Cóż takiego wydarzyło się w przeciągu ostatnich kilkudziesięciu lat? Dlaczego świadomy siebie umysł nie może się ostać nawet pod postacią całkowicie bezwolnej kukły? Czy wysunięto jakieś nowe, nieodparte argumenty filozoficzne, które przeniknęły do szerokiej publiczności i które sprawiają, że dualizm jest całkowicie nie do przyjęcia?

Niełatwo jest odpowiedzieć na pytania sformułowane w poprzednim akapicie. Bez wątpienia, czysto filozoficzne rozważania odegrały jakąś rolę i w pewnym stopniu przygotowały grunt pod skrajny materializm. Dzieła filozofów są jednak 
rzadko czytane i nieczęsto rozumiane. Z pewnością to nie one kształtują wyobrażenia wykształconego ogółu. Jestem zdania, że o wiele ważniejszy był rewolucyjnie szybki postęp nauk biologicznych. Osiągnięcia genetyki i rozwój wiedzy o mózgu odznaczają się „namacalnością", która także na zawodowych filozofów oddziałuje silniej niż ich własne spekulacje. Wydaje się, że czynnikiem, który oddziałał i oddziałuje równie mocno jest rewolucja informatyczna, a zwłaszcza badania nad sztuczną inteligencją.

Zawodowych filozofów umysłu dzieli się niekiedy na biologistów, jak John Searle (Searle 1994, 1995a,1995b, 1997), akcentujących wagę fizycznych procesów zachodzących w organicznej materii i na tych, którzy, tak jak Daniel Dennett (Dennett 1987, 1991), doceniają (a niekiedy przeceniają) rolę programu. Te dwie rewolucje (w naukach biologicznych oraz informatyczna) przeciwstawiają więc niekiedy filozofów. Z interesującego nas tutaj punktu widzenia nie ma to większego znaczenia. Obie - każda na swój sposób - uwiarygodniają pogląd, że Człowiek to model do składania. A zresztą to, co dzieli filozofów, wcale nie przeszkadza naukowcom i inżynierom, starającym się znaleźć praktyczne zastosowanie dla swoich odkryć i wynalazków; korzystają oni równie chętnie z wiedzy neurobiologów oraz umiejętności programistów i cybernetyków. Aby sobie to uświadomić, wystarczy odwołać się do przykładów, o których codziennie donosi prasa. Człowiek, który wiele lat temu stracił rękę, otrzymuje rękę artefakt. Nie tylko włada nią, ale posiada w niej wrażenia dotykowe. Inny człowiek, niewidomy od wielu lat, połączony z odpowiednim urządzeniem (na które składa się miniaturowa kamera, odpowiednio zaprogramowany komputer itd.) odzyskał w pewnej mierze wrażenia wzrokowe. Nie są one doskonałe, ale umożliwiają samodzielne poruszanie się w nowym otoczeniu itd., itd.

Współmierność „świata” neuronów i odpowiednio zaprogramowanych artefaktów staje się coraz bardziej oczywistym i coraz bardziej „namacalnym” faktem. Bardzo trudno jest się oprzeć wymowie takich przykładów. Czy człowiek to maszyna, sprytne urządzenie składające się z mniejszych części? Jeżeli ktoś przypuszcza, że tak, to może się o tym upewniać na dwa sposoby: „wyganiać ducha” z maszyny, tzn. wykazywać, że duch jest zbędny lub „majsterkować przy maszynie", tzn. wymieniać i uszkadzać różne części; rozkładać i składać większe całości... i wreszcie podjąć próbę zbudowania całości.

Filozofowie-materialiści stosowali (i stosują) pierwszą z tych metod, zespoły uczonych prowadzących badania nad sztuczną inteligencją i neurobiolodzy - drugą. Pierwszy sposób jest zawodny. Ci, którzy go stosują, narażeni są na pomyłki i przeoczenia. Cóż miałoby tutaj zresztą stanowić probierz sukcesu? Gdybyśmy kroczyli tylko tą drogą, nigdy nie pozbylibyśmy się wątpliwości (czy aby duch został rzeczywiście przegoniony?!). O ileż pewniejszy wydaje się drugi sposób. Kryteria sukcesu są tym razem jasne i czytelne. Jestem zdania, że dopiero sukcesy nauk biologicznych i badania nad sztuczną inteligencją wstrząsnęły „potoczną wyobraźnią"; uczyniły materializm „strawnym” nie tylko dla zawodowych filozofów, lecz także dla laików.

Teza, że Człowiek to model do składania brzmi agresywnie, ale - zauważmy to - jest, w zestawieniu ze standardami obowiązującymi we współczesnej 
filozofii umysłu, dość słaba. Wcale nie jest to skrajny materializm. Nie przeczymy ani istnieniu świadomości wraz z całym jej bogactwem, ani realności tzw. życia wewnętrznego. Teza ta jest zgodna zarówno z tzw. dualizmem własnościowym, jak i ze wspomnianym tutaj wcześniej epifenomenalizmem. W gruncie rzeczy wyklucza tylko tzw. dualizm substancjalny. Jest to właściwie minimum tego, co musimy przyznać, jeśli nie chcemy przeczyć oczywistym faktom. Wszak proces przebudowy i rozbudowy ludzkich organizmów właśnie się rozpoczął i dokonuje się na naszych oczach. Jeśli opisane wcześniej reakcje moich studentów są reprezentatywne, to jest to banał zdrowego rozsądku.

Teza, że Człowiek to model do składania jest nieco inaczej wyrażoną superveniencją (przekonaniem, że dwa obiekty identyczne pod względem przyrodniczym są identyczne pod każdym innym względem) oraz zdroworozsądkowym przekonaniem (uwiarygodnianym w coraz większym stopniu przez praktykę naukową), że ludzkie organizmy składają się z mniejszych części, które można z powodzeniem wymieniać lub łączyć w większe całości. Ktoś, kto twierdzi, że Człowiek to model do składania, nie twierdzi nic ponad to, że biotechnologia jest możliwa. Czy ktoś w ogóle jeszcze w to wątpi? Niekiedy można odnieść takie wrażenie. Ludzie są niepowtarzalni, unikalni... Ludzi nie można produkować tak, jak produkuje się samochody itd., itd. Gwałtowność i wielość tych protestów świadczy jednak o czymś innym. Gdyby ludzie rzeczywiście byli unikalni i niepowtarzalni, to protest byłby bezprzedmiotowy. Biotechnologia budzi powszechną grozę właśnie dlatego, że wiara w jej możliwość jest powszechna.

Tytułowa teza tego paragrafu budzi jednak grozę także wśród wielu filozofów. Czemu jednak? Wśród współczesnych filozofów nie ma (prawie) kartezjanistów. Kartezjanizm jest beznadziejny. Kartezjanizm w jakiejkolwiek formie i postaci jest skończony. Kartezjanizm upadł - raz na zawsze itd., itd. Jeśli kartezjanizm jest rzeczywiście skończony, jeśli nie ma ducha w maszynie, to w czym problem? Przecież wszyscy wiedzą, że maszyny składają się z części.

Nie ma ducha w maszynie. To był mit. Nikt już nie wierzy w duchy. Rzecz jednak w tym, że wciąż mocno wierzymy w świat, który wspiera się na tym micie. Wszystko, co robimy, mówimy, myślimy..., zakłada realne istnienie autonomicznych, niepodzielnych podmiotów, czyli duchów. Duchów-podmiotów nie ma, ale wciąż wręczamy im nagrody i wymierzamy kary. Duchów-podmiotów nie ma, ale to On lub Ona widzi, słyszy, rozumie, podejmuje decyzje i ponosi odpowiedzialność. Duchów-podmiotów nie ma, ale to On lub Ona chwyta niematerialne znaczenie naszych wypowiedzi. Duchów-podmiotów nie ma, ale wciąż miewamy do nich o coś pretensje, żal; wciąż im czegoś zazdrościmy. Duchów-podmiotów nie ma, ale nieustannie, podobnie jak autor sprawozdania reporterskiego datowanego 13 października 1784 r., poszukujemy ukrytych sprawców.

Kartezjanizm w jakiejkolwiek formie i postaci jest skończony - to refren popularnej filozoficznej piosenki. Nucąc zbyt często jedną i tę samą piosenkę, zapominamy o treści; pamiętamy tylko o melodii. Człowiek to model do składania rani uszy, bo przypomina o treści. Koniec kartezjanizmu w jakiejkolwiek formie i postaci oznacza również koniec „naszego świata” w jakiejkolwiek znanej nam formie i postaci. 
Pojęcie podmiotu-ducha odgrywa zbyt dużą rolę, pełni zbyt wiele różnych funkcji, aby mogło zostać po prostu odrzucone. Póki co niezbędny jest substytut, który w wielu różnych kontekstach mógłby spełniać podobne zadania. Trzeba przecież o coś zabiegać, do czegoś dążyć, coś chronić i coś cenić. Być może tradycyjne pojęcie podmiotu-ducha zastąpione zostanie pojęciem jakości życia organizmu (Singer 1997). Wiele na to wskazuje. Pomysł ten jest do przyjęcia z przyrodniczego punktu widzenia i odpowiada na zapotrzebowanie społeczne; zazębia się z ucieczką od odpowiedzialności i z powszechnym hedonizmem. Czuje się, że jest w duchu epoki.

Jak będzie wyglądał świat, w którym podmiot-duch zostanie wyeliminowany przez jakość życia organizmu? Nie sposób odpowiedzieć na to pytanie. Ograniczę się do jednego przykładu, a mianowicie do eutanazji. Póki co, eutanazja ma dochodzić do skutku w wyniku prośby zainteresowanej nią osoby. On lub ona ma decydować o tym, czy jakość życia jest jeszcze dostatecznie duża, czy też już spadła poniżej pewnego minimum. W świecie bez podmiotu-ducha jest to jednak absurd, który długo trwać nie może. On lub ona przecież nie istnieją. To kartezjańskie fikcje! Do badania jakości życia organizmu (podobnie jak do badania stanu wątroby) przygotowany jest specjalista wyposażony w odpowiednie artefakty. On lub ona - niematerialny duch - za pomocą magicznego narzędzia, introspekcji, miałby rozstrzygać, jaka jest rzeczywista jakość życia organizmu? Przecież to nonsens, zabobon i ciemnota; echo wiary w duchy i uprzywilejowane dostępy. Od tego są skanery mózgu trzeciej generacji i odpowiednie tabele.

Być może uda się jednak jakoś zrekonstruować pojęcie podmiotu, pogodzić wiedzę przyrodniczą z elementarnymi intuicjami i odczuciami. Filozofia, póki co, nie nadąża za postępami nauk przyrodniczych. Wszak podmiot - to niekoniecznie niepodzielny i niematerialny duch. Istnieje wiele innych możliwości. Zapewne jest coś na rzeczy. Jeśli jednak powstanie nowe pojęcie podmiotu, to będzie ono zupełnie inne. Nowy podmiot będzie podmiotem do składania. O tym, czym on jest i jakie są jego prawa decydować będą biotechnolodzy oraz inżynierowie.

Być może uda się jednak jakoś wywikłać ducha z mózgu tkanin... Poznanie przyrodnicze nie jest wszak zakończone. Wiele się może jeszcze wydarzyć... Być może powstanie jakaś nowa, nieznana forma duchowości. Być może? 


\section{Rozdział drugi}

\section{O TYM, CO ISTNIEJE}

Historia filozoficznych sporów o to, co istnieje jest długa i burzliwa. Gdyby ktoś zadał sobie trud wyliczenia bytów podejrzewanych w różnych czasach przez sławnych filozofów o istnienie, to lista taka, niczym jadłospis w wykwintnej restauracji, mogłaby przyprawić o zawrót głowy; niejeden „ontologiczny smakosz” znalazłby tam coś dla siebie. My, w tej pracy, nie jesteśmy w stanie przedstawić - choćby pobieżnie - historii tych sporów. Wymagałoby to rozległych studiów, których nie prowadziliśmy. Ograniczymy się do prezentacji i porównania dwóch różnych koncepcji istnienia. Pierwsza z nich głosi, że właściwą miarą istnienia jest język, którym się posługujemy; druga, że są nią tzw. moce przyczynowe. Pierwsza z tych koncepcji przyczyniła się do powstania i uwiarygodnienia doktryny, którą w dalszym ciągu będę określał mianem kreacjonizmu lingwistycznego; druga, wydaje się, zaczyna być dominującą koncepcją na gruncie współczesnej (analitycznej) filozofii umysłu. Jest to koncepcja, do której chętnie odwołują się filozofowie-naturaliści.

Plan tej pracy jest następujący. Wpierw przedstawimy kreacjonizm lingwistyczny i postaramy się zrozumieć idee, które się za nim kryją. Następnie wyjaśnimy - w ogólnym zarysie - koncepcję, wedle której istnieć, to tyle, co posiadać określone moce przyczynowe. W końcu - porównamy oba podejścia.

\section{Kreacjonizm lingwistyczny i jego głębie}

\subsection{Próba określenia}

Przez kreacjonizm lingwistyczny rozumiemy przekonanie, że świat jest, w pewnym sensie, stwarzany przez język. Przekonanie to, mamy wrażenie, upo- 
wszechniło się niezwykle i jest zawarte implicite - jako coś samo-oczywistego - w pracach wielu różnych filozofów. Niektórzy studenci filozofii traktują je wręcz jako rodzaj filozoficznego abecadła. O tym, że świata rzeczywistego nie ma, a to, z czym obcujemy, to pewien językowy konstrukt, można się często dowiedzieć nawet od studenta drugiego roku filozofii. Fantastyczna, zdawałoby się, idea zadomowiła się na dobre w piśmiennictwie filozoficznym i, rzec można, przeniknęła pod "filozoficzne strzechy".

Wyjaśnijmy od razu, że pomysł, iż język służy do stwarzania świata uważamy za niedorzeczny i to zarówno w jego skrajnych, jak i bardziej umiarkowanych wcieleniach. Próbując dociec sensu tej zastanawiającej doktryny i argumentów, którymi ona się karmi, odwołamy się do prac tych filozofów, którzy jasno i prosto tłumaczą, w czym rzecz i pokazują na prostych przykładach, na czym, ich zdaniem, polega kreacyjna funkcja języka. Otóż, jak „stwarza” się świat można się dowiedzieć, w ogólnym zarysie, z książki Nelsona Goodmana zatytułowanej Jak tworzymy świat (Goodman 1997). Bardzo dokładny przepis na tworzenie różnych światów zawiera natomiast jedna z prac Hilarego Putnama (Putnam 1998: 343-344). Ponieważ cenimy dokładność, skupimy się na tej właśnie pracy.

Weźmy, powiada Putnam, świat, w którym znajdują się trzy indywidua: X1, X2, i X3. Ile przedmiotów znajduje się w tym świecie? Czyż nie powiedzieliśmy, że trzy? Czy mogą się tam znajdować przedmioty w jakiejś innej liczbie? - zapytuje retorycznie sławny filozof. Otóż - mogą. Wystarczy, że uwzględnimy tzw. mereologiczne sumy owych trzech indywiduów. Jeśli to zrobimy, otrzymamy świat złożony z siedmiu indywiduów, a mianowicie z X1, X2, X3, X1+X2, X1+X3, X2+X3, $X 1+X 2+X 3$. W ten sposób stworzyliśmy nowy świat, taki, w którym znajduje się siedem obiektów. I teraz mamy już dwa światy: jeden, w którym są trzy obiekty i drugi, w którym znajduje się siedem różnych obiektów. Właśnie w ten sposób tworzy się nowe światy.

Przedstawione powyżej rozumowanie ma nas przekonać, że nie ma tzw. gotowego świata. Świat trzeba sobie dopiero stworzyć, a można to, jak widać, zrobić na wiele sposobów. Pogląd, zgodnie z którym istnieje jeden gotowy świat, to realizm metafizyczny. Realizm metafizyczny jest, wedle Putnama, stanowiskiem błędnym, bo nie radzi sobie z opisaną wyżej możliwością tworzenia różnych światów. Mówiąc ściślej, realizm metafizyczny próbuje sobie poradzić z tą trudnością, ale bez powodzenia.

Sposób podejścia klasycznego realizmu metafizycznego do tego rodzaju problemów jest dobrze znany. Należy stwierdzić, że istnieje jeden jedyny świat (porównajmy go do ciasta), z którego możemy wykrawać różnego kształtu ciasteczka. Jednak metafora "foremki do ciasta” upada wobec pytania: „Z jakich części składa się ciasto" (Putnam 1998: 344)

Tytułem dygresji zauważmy, że przytoczony właśnie fragment tekstu jest interesujący nie tylko dla filozofów, wynika zeń bowiem m.in., że np. ten oto wypieczony i wystawiony na sprzedaż tort nie jest gotowy (i trzeba go dopiero stworzyć) dlatego, że cukiernik nie wie, z ilu części się on składa. Cukiernicy - naiwni metafizyczni realiści - mogą się wiele nauczyć od filozofów. 


\subsection{Realizm metafizyczny, wewnętrzny, naiwny... i normalny realizm}

Powróćmy do filozofii i przyjrzyjmy się bliżej Putnamowskiej metodzie tworzenia światów. Nie będziemy tworzyć całych światów, nie jesteśmy aż tak ambitni. Wystarczy, jeśli nauczymy się tworzyć najbliższe otoczenie. Potrenujemy na izbach.

Załóżmy, że znajduję się w pewnej izbie. Przyjmijmy, że w izbie tej znajdują się ponadto stół, trzy krzesła, jeden kot oraz fotel, w którym właśnie siedzę. Czyż izba nie jest już stworzona? Oczywiście, że nie. Myśląc tak, bylibyśmy naiwnymi metafizycznymi realistami. Izbę trzeba dopiero stworzyć i można to zrobić na wiele różnych sposobów. Czy to znaczy, że trzeba odmalować ściany, poprzestawiać meble lub dokupić biurko? Nic z tych rzeczy. Filozofowie tworzą izby w inny sposób. Najpierw musimy odpowiedzieć na pytanie, Ile obiektów znajduje się w izbie? Przecież to jasne: stół, trzy krzesła, fotel, kot oraz ja sam. Razem siedem. A mój nos, czyż nie jest kolejnym obiektem? Dobrze, niech będzie - razem jest ich osiem. A uszy, czyż nie są obiektami? Jeśli policzymy uszy, będzie ich dziesięć. A jeśli uszy kota, to dwanaście. A jego nos, łapy, wąsy... Mówicie, że izba jest stworzona, a nie wiecie, ile obiektów się w niej znajduje. Sądzicie, że teraz już wiecie, tylko nie chce wam się liczyć. Mylicie się. Niech mereologiczna suma mego nosa i którejkolwiek z łap kota zwie się fruclem, mereologiczna suma mego prawego ucha i nogi od stołu ruclem, a mereologiczna suma wskazującego palca prawej ręki i pewnego krzesła bartolem. Widzicie, izba nie jest stworzona. Właśnie stworzyliśmy frucle, rucle i bartole.

I właśnie w ten sposób stwarza się izbę i to nie są żarty, lecz bardzo poważna filozofia. Czytelników niezorientowanych w zawiłościach współczesnej filozofii (naiwnych metafizycznych realistów) uprasza się o zachowanie należytej powagi. Zauważmy więc (całkiem serio), że co się tyczy stwarzania, istnieją dwa dobrze znane i sprawdzone wzory. Jeden pochodzi od biblijnego Jehowy, drugi od platońskiego demiurga. Jehowa stworzył świat z nicości za sprawą zwykłego: Niech się tak stanie. Powiedział np. Niech się staną wieloryby wielkie i to wystarczyło. Demiurg - niczym garncarz - korzystał z gotowego tworzywa. Otóż, z pewnością, tworząc izbę, nie wzorowaliśmy się na Biblii. Weźmy np. pod uwagę frucle. Nie stworzylibyśmy frucli, gdyby nie było mego nosa i łap kota. Gdyby nie było mego nosa i łap kota, to moglibyśmy mówić: Niech się staną frucle, niech się staną frucle... i nic by to nie pomogło. Być może, w takim razie, robiliśmy to, co demiurg. Korzystając z gotowego tworzywa stworzyliśmy frucle, rucle i bartole. Otóż, nie wydaje się. Różnica pomiędzy nami i demiurgiem jest też oczywista i łatwa do wyjaśnienia. Demiurg wytworzył cały szereg konkretnych indywidualnych obiektów, my natomiast niczego nie wytworzyliśmy. Demiurg dokonał wielu istotnych przekształceń, my natomiast nie dokonaliśmy żadnych zmian. Tego, co zrobiliśmy z izbą, nie wykryje ani ludzkie oko, ani żadne przyrządy. Jeżeli chcielibyśmy się trzymać porównań z garncarstwem, to nas należałoby przyrównać do garncarzy, którzy brzydzą się kontaktu z gliną.

Nim przejdziemy dalej, wprowadzimy pewne pojęcie. Otóż filozofowie, zajmujący się stwarzaniem izb i światów, zwykli posługiwać się terminem realizm 
opatrzonym różnymi dodatkami. Bywa, że mówi się o realizmie naiwnym, realizmie metafizycznym, realizmie wewnętrznym itd. My też chcemy być realistami, ale nie odpowiada nam żadna $z$ istniejących kwalifikacji. Chcemy być nazywani normalnymi realistami. Przez normalny realizm rozumieć będziemy przekonanie, że pojęciowa twórczość - tworzenie nowych pojęć - nie ma żadnego wpływu ani na izbę, ani na świat. Normalny realizm jest więc tylko stanowiskiem w sporze o stwarzanie izby lub świata za pomocą tworzenia nowych pojęć. Tylko tyle.

Normalny realizm ma tę przewagę nad innymi postaciami realizmu, że jego zasadność jest bardzo dobrze udokumentowana. Możemy przecież sfilmować w pewnej izbie pewnego człowieka, uchwycić moment, w którym zaczyna on tworzyć nowe pojęcia i następnie przejrzeć cały film, klatka po klatce. Przekonamy się naocznie, że pojęciowa twórczość nie ma żadnego wpływu na izbę. Domyślamy się, że w tym momencie wielu filozofów zarzuci nam naiwność, a nawet prostactwo. Nasze prostactwo jest jednak wymuszone mętnością ich metafor. A ponadto, jeżeli kreacjonizm lingwistyczny szokuje ludzi, którzy nie są zawodowymi filozofami, to nie dlatego, że są oni metafizycznymi czy naiwnymi realistami, ale dlatego, że są normalnymi realistami - wiedzą z doświadczenia, że pojęciowa twórczość nie ma żadnego wpływu ani na izby, ani na świat. Zawodowi filozofowie lubią zarzucać ludziom spoza cechu naiwność i powierzchowność. Na czym jednak miałaby polegać nasza naiwność?! Być może na przekonaniu, że klisza fotograficzna jest dostatecznie czułym instrumentem, aby wykryć wpływ językowej twórczości. Być może należałoby zainstalować jakieś inne, czulsze instrumenty... Śmiemy jednak twierdzić, że wskazania wszystkich innych instrumentów, wyłączywszy instrumenty rejestrujące aktywność naszych mózgów, byłyby podobne.

\subsection{Filozoficzne głębie}

W tym miejscu niejeden filozof powiedziałby zapewne: Wasza naiwność nie polega na stosowaniu naiwnych instrumentów. Wasza naiwność polega na braku odpowiednio głębokiego filozoficznego namysłu. Sytuacja zaczyna być poważna i nie jesteśmy pewni, czy uda się nam trafnie odtworzyć argumenty, przemawiające na rzecz lingwistycznego kreacjonizmu. Aby ułatwić sobie zadanie, będziemy mówili o dwóch głębiach, pierwszej i drugiej filozoficznej głębi. Mamy przy tym wrażenie, że druga uchodzi za głębszą od pierwszej. Być może głębie te zdołają nas przekonać, że jednak stwarzamy izbę. (Przedstawionych poglądów nie przypisujemy żadnym konkretnym filozofom, ponieważ chodzi nam o pewien sposób czy też styl myślenia, który - jak sądzimy - jest rozpowszechniony)

Pierwsza filozoficzna głębia głosi mniej więcej coś takiego. Wyobraź sobie raz jeszcze wszystko od początku. Jest izba, a w izbie znajdują się dwa stoły, trzy krzesła, jeden kot oraz fotel, w którym siedzisz. Nie ma tam natomiast dla ciebie ani frucli, ani rucli, ani bartoli. Zbliża się krytyczny moment, tworzysz pojęcia frucla, rucla i bartola. I oto nagle frucle, rucle i bartole zaczynają dla ciebie istnieć. Pierwsza filozoficzna głębia lubi używać zwrotów: dla ciebie, dla mnie, dla nie- 
go, dla niej itd. i dlatego będę te zwroty wyróżniał podwójnie - kursywą i pogrubionym drukiem. Nim odpowiemy pierwszej filozoficznej głębi, krótka uwaga. Otóż my, normalni realiści, jesteśmy być może powierzchowni, ale za to bardzo elastyczni i przyswajamy sobie żargon pierwszej głębi. Będziemy od tej pory mówili: dla mnie, dla niego i dla niej. Odpowiedź natomiast, której udzielamy pierwszej głębi, jest, jak cały nasz realizm, po prostu normalna. Otóż twierdzimy, że frucle, rucle i bartole istniały dla nas, a także dla mnie również przed utworzeniem tego pojęcia. Weźmy pod uwagę np. rucle i przypomnijmy, że rucla to mereologiczna suma mego prawego ucha i jakiejś nogi od stołu. Aby ustalić do końca uwagę, skoncentrujmy się na jednej, konkretnej osobie (piszącym niniejsze) i jednej indywidualnej rucli, a mianowicie na mereologicznej sumie mego prawego ucha i tej nogi od stołu, o którą akurat ociera się kot. Rucla ta dla mnie teraz istnieje. Rucla ta, u licha, istniała dla mnie na długo przed utworzeniem pojęcia rucli. Teraz mogę porąbać fragment rucli i zużyć go na opał; mogłem to również zrobić na długo przed utworzeniem pojęcia rucli. Teraz mogę w inny fragment rozważanej rucli wpiąć kolczyk; w ten sam fragment tej samej rucli mogłem jednak wpiąć kolczyk przed utworzeniem pojęcia rucli itd., itd. Rucla - ta rucla - istnieje dla mnie teraz i istniała dla mnie przedtem. Przedtem, nim utworzyłeś to pojęcie, rzecze pierwsza głębia, nie zauważałeś rucli, nie zwracałeś na nie uwagi, nawet nie przeczuwałeś ich istnienia. Teraz zauważasz rucle, zwracasz na nie uwagę, dopiero teraz je „widzisz”. Właśnie w tym sensie rucle dla ciebie przedtem nie istniały, a teraz dla ciebie istnieją. Borowaliśmy długo, ale chyba jesteśmy blisko nerwu. Sięgamy właśnie dna pierwszej filozoficznej głębi. Otóż, pierwsza głębia utożsamia zauważanie czy też zwracanie uwagi na różne obiekty z ich stwarzaniem. Nie chodzi tutaj, rzecz jasna, o jakiekolwiek zauważanie czy zwracanie uwagi.

Zauważać bądź zwracać uwagę na różne obiekty czy aspekty rzeczywistości można w różny sposób. Mogę zauważać, dostrzegać, zwracać uwagę itd. na różne obiekty, np. kręcąc głową, wytężając wzrok i słuch; mogę też zauważać czy zwracać uwagę na nowe obiekty, ucząc się nowych pojęć bądź je tworząc. Otóż, pierwsza głębia jest, co się tyczy stwarzania, bardzo wybredna. Załóżmy, że przekręcam nieco głowę i zaczynam zauważać szafę, której wcześniej nie zauważałem. Czy to znaczy, że stworzyłem szafę? Ależ skąd, myśleć tak byłoby absurdem. Załóżmy teraz, że tworzę pojęcie rucla i zaczynam zauważać rucle, których wcześniej nie zauważałem. Czy to znaczy, że stworzyłem cztery rucle? Tak, stworzyłeś cztery rucle. Takie jest, jak się wydaje, stanowisko pierwszej głębi.

Ludzie od dawien dawna uczyli się różnych pojęć i, jeżeli okazywało się to potrzebne, tworzyli nowe. Ludzie od dawien dawna wiedzieli również, że izby można opisywać w różny sposób, koncentrując się bądź na kształtach, bądź na kolorach, bądź na składzie chemicznym, bądź na odległości od księżyca, bądź na fruclach, ruclach i bartolach. Wiedzieli o tym wszyscy, filozofów nie wyłączając. Do pewnego momentu, jak się wydaje, panowała również zgoda powszechna co do oceny lub interpretacji tego rodzaju działalności; tzn. wszyscy, filozofów nie wyłączając, byli przekonani, że tworząc nowe pojęcia lub nowe opisy, niczego nie robimy poza tworzeniem nowych pojęć i nowych opisów. Nikomu nie przychodziło do głowy, że izba lub świat nie są gotowe lub nie są stworzone i że trzeba je do- 
piero stworzyć, a narzędziem kreacji są pojęcia. Filozofowie miewali i wcześniej różne dziwne pomysły. Długo by o tym pisać. Kreacjonizm lingwistyczny to jednak nawet w gabinecie filozoficznych osobliwości niezwykły eksponat. Wierzyć w to, że krzesła tworzy się, tworząc pojęcie krzesła, a frucle tworząc pojęcie frucla? Jak to w ogóle możliwe? Być może, my - normalni realiści - czegoś tutaj nie rozumiemy. Muszą istnieć jakieś inne, głębsze argumenty. Przejdźmy do drugiej głębi.

Druga filozoficzna głębia powiada mniej więcej coś takiego. Twierdzicie, że izba jest stworzona, prawda? W takim razie powiedzcie, jaka ona jest, ta stworzona izba, opiszcie ją. Jeżeli zaczniemy opisywać izbę, powiadając np., że jest w niej stół, krzesła i kot, druga głębia zauważy, że są tam frucle, rucle i bartole. Jeżeli powiemy, że są tam frucle, rucle i bartole, głębia powie, że są tam jeszcze trele, frele i morele itd. Ktoś mógłby w tym miejscu zauważyć, że druga głębia to nieco inaczej wyrażony chwyt-propozycja: policz obiekty! Druga głębia jest jednak bardzo sprytna, na wszystko ma gotową odpowiedź i dlatego musimy ją rozważyć oddzielnie. Gdybyśmy powiedzieli, że przecież możemy wszystko sfilmować i w ten sposób przekonać się, że pojęciowa twórczość nie ma wpływu na izbę, druga głębia poprosi nas o opisanie tego, co widzimy na wyświetlanym filmie i o zdefiniowanie pojęcia wpływu. Jeżeli zaproponujemy zainstalowanie przyrządów, druga głębia poprosi o opisanie przyrządów oraz ich wskazań itd. To, o czym chce nas przekonać druga głębia, można by wysłowić jakoś tak. Człowiek naiwny myśli, że oprócz opisów świata, istnieje opisywany świat. Głęboki filozof wie natomiast, że naprawdę i w rzeczywistości istnieją tylko korelaty opisów. I na nic zda się mówić, że przecież jeszcze widzimy, słyszymy, dotykamy..., że przesuwamy szafy, wbijamy gwoździe w ściany i prowadzimy samochody. Druga głębia jest niewzruszona. Opisz, opisz, opisz... towarzyszy, niby cień, wszystkim naszym argumentom. Druga głębia - całkiem na serio - jest przekonana, że poza językiem w ogóle nie ma świata. Kreacjonizm lingwistyczny za pośrednictwem drugiej głębi prowadzi do czegoś, co można nazwać Nowym sporem o istnienie świata. Spór ten jest pod wieloma względami podobny do pierwszego sporu o istnienie świata. Widzimy tu cały szereg ciekawych analogii.

\section{Dwa spory o istnienie świata (podobieństwa i różnice)}

Pierwszy spór o istnienie świata narodził się wraz z wystąpieniem Kartezjusza, trwał przez kilkaset lat i umarł śmiercią naturalną gdzieś na początku drugiej połowy XX wieku. Siłą napędową pierwszego sporu było przekonanie większości filozofów o istnieniu niematerialnego ducha, podmiotu, umysłu, świadomości itd. oraz przekonanie, że ów podmiot, duch, umysł... poznaje, spostrzega, widzi... obiekty, rzeczy, świat czy izby za pośrednictwem obrazów, wyglądów, danych wrażeniowych, danych zmysłowych itd. Świata samego - powiadano - nikt nigdy nie widział. Dane są nam tylko obrazy, wrażenia, wyglądy, zjawiska itd. Wśród 
spierających się filozofów wyróżniano realistów (świat jest podobny do obrazu), umiarkowanych realistów (jaki jest świat, nie wiadomo, ale przecież muszą istnieć jakieś rzeczy same w sobie, przyczyny obrazów) oraz idealistów, którzy powiadali, że skoro dane są tylko obrazy, to widocznie tylko one istnieją. Świat, wedle tych ostatnich, miał znajdować się w umyśle. W czasach, gdy myślenie w kategoriach obrazów i wyglądów kwitło, zwykłych ludzi, upierających się, że wsiadają np. na konia, a nie na wyglądy konia, zbywano epitetem: naiwny realista!

Pierwszy spór o istnienie świata zakończył się wraz z wygaśnięciem wiary $\mathrm{w}$ istnienie niematerialnego ducha-podmiotu. Długo by o tym pisać. W każdym razie filozofowie (a przynajmniej olbrzymia ich większość) uznali, że ducha nie ma, ostała się jeno cielesna maszyna. Spadkiem po pierwszym sporze o istnienie świata jest kłopotliwa masa upadłościowa - owe celebrowane przez kilkaset lat dane wrażeniowe i obrazy. Wygodnym locum dla tych bytów był niematerialny umysł. Teraz nie mają się gdzie podziać. Problem ten zwany jest z łacińska problemem qualiów i zajmuje się nim wielu różnych filozofów. O stopniu filozoficznego zamieszania wokół qualiów najlepiej świadczy fakt, że niektórzy znani myśliciele, np. Daniel Dennett (1991), są przekonani, że qualiów w ogóle nie ma, podczas gdy inni znani myśliciele, np. David Chalmers (1996) przypuszczają, że nawet termostaty posiadają qualia. To, czy termostaty miewają bóle i swędzenia, nie jest jednak (na szczęście) przedmiotem tej pracy. Przejdźmy do drugiego sporu o istnienie świata.

Trudno byłoby nam wskazać moment, w którym się rozpoczął, a jeszcze trudniej opisać jego koleje. Wymagałoby to gruntownych studiów, których nie prowadziliśmy. Sądzimy jednak, że potrafimy wskazać główną przyczynę powstania tego sporu i udokumentować nasz pogląd przykładami. Zaznaczmy jednak, że jest to bardzo powierzchowna i pobieżna analiza. Otóż sądzimy, że jedną z głównych przyczyn powstania drugiego sporu o istnienie świata oraz blisko z nim powiązanego kreacjonizmu lingwistycznego był tzw. lingwistyczny zwrot $\boldsymbol{w}$ filozofii. Filozofowie, w pewnym momencie (choć moment ten trwał przez wiele lat), „przesiedli” się z obrazów i danych wrażeniowych na język. Zamiast o widzialnych i niewidzialnych obiektach zaczęto mówić o terminach obserwacyjnych i teoretycznych pewnego języka; zamiast o prawdach dotyczących świata, zaczęto mówić o gorzej lub lepiej potwierdzonych empirycznie zdaniach pewnego języka; zamiast o świecie - raczej o modelach pewnej teorii, wyrażonej w pewnym języku. W języku, z językiem i przez język. Nikt, poza językiem, nie będzie zbawiony! Wreszcie język stał się miarą wszechrzeczy, również miarą istnienia. Czy istnieje subiektywne wrażenie bólu? Takie pytanie jest źle postawione, poucza nas jeden z najlepiej znanych, najbardziej cenionych i - jak się wydaje - najbardziej wpływowych filozofów analitycznych, Ludwig Wittgenstein (Wittgenstein 1972). Dobrze postawione pytanie brzmi: Czy możliwy jest prywatny język przeżyć? W innym miejscu ten sam filozof zauważa: Granice mego świata są granicami mego języka. Ważnym wydarzeniem w dziejach przekształcania wszystkich pytań i wszystkich sporów w pytania i spory dotyczące pewnego języka był artykuł amerykańskiego filozofa Willard van Orman Quine O tym, co istnieje. W pracy tej autor zaproponował, aby przestarzałe pojęcie istnienia zastąpić pojęciem zobowiązania ontolo- 
gicznego. Każdy, kto posługuje się pewnym językiem, zaciąga dług ontologiczny, zobowiązuje się (a przynajmniej powinien to zrobić, jeśli jest uczciwy) uznawać istnienie pewnych obiektów, tych mianowicie, które są wartościami zmiennych języka, którym się posługuje:

Być uznanym za przedmiot istniejący to po prostu i tylko tyle, co być zaliczonym do wartości zmiennych [...]. Zmienne kwantyfikacji wyznaczają całą naszą ontologię (Quine 1969: 25).

Innymi słowy, jeśli ktoś gotów jest utrzymywać, że Niektóre krzesła są wykonane z drewna, to zaciąga dług ontologiczny w stosunku do krzeseł; jeśli twierdzi, że Każda frucla waży $2 \mathrm{~kg}$, to zadłuża się względem frucli itd. Propozycja Quine’a wielce się spodobała filozofom analitycznym. Dla wielu zdawała się oznaczać koniec jałowych sporów o to, co rzeczywiście istnieje. Nie zajmuj się istnieniem, zainteresuj się językiem. To, co dla ciebie istnieje, zależy od tego, jakim językiem się posługujesz i jak to robisz. Granice istniejących dla ciebie bytów są granicami wartości zmiennych twojego języka. Quine elegancko zazębił się z Wittgensteinem.

$\mathrm{Na}$ jednym z forów dyskusyjnych (internet) jeden z dyskutantów stwierdził w pewnym momencie, że tzw. filozofia analityczna jedynie nawodniła grunt pod postmodernizm. Zrazu pogląd ten bardzo mnie oburzył. W trakcie obmyślania repliki zacząłem sobie uświadamiać, ile racji jest w tej krótkiej uwadze. Rzeczywiście, analityczni filozofowie języka „utkali” swymi rozważaniami coś, co można byłoby nazwać „zasłoną z języka” i w ten sposób przyczynili się do powstania kreacjonizmu lingwistycznego oraz drugiego sporu o istnienie świata. Porównajmy te spory.

W pierwszym z nich funkcję zasłony pełniły obrazy, dane wrażeniowe itd., w drugim taką funkcję pełni język. Uczestnicy pierwszego sporu byli przekonani, że to, co widzimy, spostrzegamy, poznajemy, do czego jedynie mamy dostęp - to obrazy lub, używając nieco innego żargonu, kombinacje danych wrażeniowych. Uczestnicy drugiego sporu są przekonani, że to, co widzimy, spostrzegamy, poznajemy, do czego jedynie mamy dostęp to, w gruncie rzeczy, ontologia pewnego języka. Dobre tło dla jednego i drugiego sporu stanowią istoty prymitywne, prefilozoficzne, tzw. naiwni realiści. Naiwny realista sądzi np., że widzi krzesło. Człowiek po inicjacji filozoficznej nr 1 (wprowadzony w istotę pierwszego sporu) wie, że widzi tylko obraz krzesła. Człowiek po inicjacji filozoficznej nr 2 (np. po wykładzie ze współczesnej filozofii języka) wie, że widzi tylko ontologię własnego języka. Gdyby język, i co za tym idzie ontologia, były inne, to widziałby centrum frela lub połowę trela.

Ludzi po inicjacji filozoficznej nr 2 można by podzielić (tak jak i w przypadku pierwszego sporu) na umiarkowanych realistów oraz idealistów. Przykładem umiarkowanego realisty jest Hilary Putnam. Filozof ten, zdaje się, sądzi (a w każdym razie kiedyś sądził), że coś istnieje, jakieś bliżej nieokreślone $X$, ale to coś, owo $X$, nie jest jeszcze światem. Świat trzeba dopiero wytworzyć. Świat wytwarza się, robi, konstruuje (nie jestem pewien, jak należy tłumaczyć w tym kontekście angielski czasownik to make) tak samo, jak wytwarza się, robi lub konstruuje izby; tzn. - przypomnijmy - tworząc aparat pojęciowy. Po utworzeniu aparatu pojęciowego z X-a powstaje świat. W zależności od tego, jaki aparat pojęciowy utworzyliśmy, jaka jest ontologia naszego języka, powstały świat jest światem stołów, 
krzeseł i szaf lub frucli, rucli i bartoli. Wyrażając to samo w kantowskim żargonie, moglibyśmy powiedzieć, że $X$ to rzecz sama w sobie, a świat to zjawisko. Putnam to jednak nie Kant. U Kanta istnieje jeden jedyny świat-zjawisko, który jest tworzony (jeśli można się tak wyrazić) bez świadomego i twórczego udziału jednostki. Tym razem sytuacja jest inna, o wiele bardziej komfortowa. Narzędziem tworzenia jest język i, co za tym idzie, możemy sobie stworzyć tyle różnych światów-zjawisk, ile się nam podoba. Świat stołów, krzeseł i szaf lub frucli, rucli i bartoli oraz treli, freli i moreli itd., itd. Stwarzanie światów-zjawisk w tej nowej wersji to miłe i bezstresowe zajęcie, godna polecenia rozrywka.

Hilary Putnam to, jako się rzekło, umiarkowany realista. Co jednak sądzą idealiści? Otóż jest pewien kłopot z odpowiedzią na to pytanie. Po pierwsze, chodzi tu o ludzi posługujących się nieomal wyłącznie metaforami, a przy tym niesłychanie drażliwych i bojowych. Odwoływanie się do nazwisk lub cytatów naraziłoby nas na niekończące się polemiki i oskarżenia o niewłaściwe odczytanie metafor. Po drugie, mówiąc o idealistach, mamy na myśli filozofów o rzeczywiście bardzo różnej proweniencji. Byliby to w każdym razie m.in. tzw. konstruktywiści społeczni, twórczo rozwijający myśl Thomasa Kuhna (Kuhn 1968) o społecznych determinantach nauki, relatywiści kulturowi, powołujący się na hipotezę Sapiro-Whorfa (Sapir (1978), Whorf (2002)) i wreszcie najrozmaitsi postmoderniści. Różnice między tymi myślicielami są, $z$ interesującego nas punktu widzenia, do pominięcia. Wszyscy oni żywią przekonanie, że świata rzeczywistego w ogóle nie ma. Łączy ich ponadto wiara, że podstawowym narzędziem służącym do stwarzania światów jest język, który nie służy do opisywania świata. Język (wspomagany ewentualnie przez determinanty społeczne i kulturowe) służy do stwarzania różnych światów. Otrzymane tą drogą produkty bywają nazywane perspektywami, dyskursami, narracjami itd.

Ponieważ różnica pomiędzy umiarkowanym realizmem a idealizmem może się wydać mglista, spróbujmy uczynić ją wyraźną. Wielce pomocny będzie tu jeszcze raz Hilary Putnam, który wielokrotnie opisuje i akcentuje tę różnicę (Putnam 1981, 1988, 1989). Wedle tego filozofa, to, że nie ma stworzonego świata wcale nie oznacza, że nie ma żadnych prawd do odkrycia. Jak już raz stworzymy świat, to wtedy są prawdy do odkrycia i są fakty. Wedle idealistów natomiast, nigdy, przenigdy i w żadnych okolicznościach nie ma żadnych prawd do odkrycia, żadnych faktów. Wyjaśnijmy tę różnicę na prostym przykładzie. Tym razem nie będzie to izba i frucle, bo te już się nam znudziły. Wyobraźmy sobie, że właśnie utworzyliśmy pojęcie stawu i pojęcie żaby. Wedle prezentowanej tu ideologii, tym samym stworzyliśmy stawy i żaby. Wcześniej ich nie było, ale teraz już są. Jeśli mamy już stawy i żaby, to - wedle Hilarego Putnama - można byłoby odkryć cały szereg prawd o stawach i żabach (np., że w tym oto stawie znajduje się 50 żab). Byłoby to autentyczne odkrycie - wypompowujemy wodę i odkrywamy, dowiadujemy się, ustalamy, że w tym oto stawie jest raz, dwa, trzy, cztery... pięćdziesiąt żab. Byłby to pewien fakt; zrelatywizowany do stwowo-żabiego dyskursu, ale jednak fakt. Wedle idealistów natomiast wszystko, również to, że w tym oto stawie mamy 50 żab, byłoby konstrukcją, dyskursem, narracją itd. nie mającą oparcia ani w żabach, ani w stawach. Zapewne nie wszyscy umieją liczyć żaby, ale za to 
wszyscy (również filozofowie) umieją liczyć pieniądze. Trudno więc zrozumieć, jak to możliwe, że istnieją ludzie głoszący takie poglądy... Cóż jednak można na to poradzić, skoro za powielanie poglądu, że niczego nie można policzyć można zarobić i policzyć niemałe pieniądze.

Powtórzmy raz jeszcze. Nigdy niczego nie odkrywamy, ani nie ustalamy. Nie ma też żadnych mitycznych faktów. Wszystko jest konstruktem, dyskursem, narracją. Pristley nie odkrył tlenu, tylko go skonstruował. Meteorolodzy nie opisują i nie przewidują pogody, tylko ją konstruują, a fizyka i chemia to gatunki literackie itd., itd.

Mówiliśmy tutaj o dwóch sporach o istnienie świata, pierwszym i drugim. Porównajmy idealistyczne żargony. Filozofowie-idealiści, biorący udział w pierwszym sporze, powiadali: To nie deszcz cię zmoczył, tylko znajdujący się w twoim umyśle obraz deszczu, kombinacja danych wrażeniowych, to nie wiatr zawiał, tylko kombinacja danych wrażeniowych itd. Współcześni idealiści powiadają: Zmoczył cię konstrukt, dyskurs, a czapkę z głowy zdmuchnęła ci narracja.

Pomiędzy idealistami á la wrażenia a idealistami á la narracja zachodzi jeszcze jedna, choć już mniej filozoficzna, różnica. Ci pierwsi zachowywali się kulturalnie i spokojnie przedkładali swoje racje. Dialogi pomiędzy Hylasem i Filonousem (Berkeley 2006) toczą się w przyjaznej atmosferze. Ci drudzy bywają agresywni i oskarżają swych oponentów o różne brzydkie rzeczy. Ktoś, kto utrzymuje, że oprócz narracji istnieją jakieś prawdy, fakty czy obiekty, to człowiek podejrzany. Chciałby za pomocą rzekomych prawd, faktów itd. zniewolić i ograniczyć inne dyskursy i narracje. Ktoś, kto dzisiaj mówi, że prawdą jest, że w stawie znajduje się 50 żab, jutro wybuduje obozy koncentracyjne.

Kończymy w tym miejscu przedstawianie kreacjonizmu lingwistycznego i drugiego sporu o istnienie świata. Jesteśmy zdania, że mamy tutaj do czynienia nie ze sporem, mającym oparcie w realnych trudnościach, ale z patologią. Sądzimy też, że trafnie zidentyfikowaliśmy jednego z bakcyli wywołującego tę dziwną chorobę. Jest nim lingwistyczny zwrot w kwestii istnienia - przekonanie, że język jest jego miarą. Do wywołania i pogłębienia tej choroby w niemałym stopniu przyczynili się filozofowie analityczni; również ci, którzy starają się zachować realizm w jakiejś postaci. Jeżeli ktoś powiada, że izba nie jest gotowa (stworzona) i - dalej - że tworząc aparat pojęciowy, dopiero tworzymy izbę, nie powinien się specjalnie dziwić ani oburzać, jeśli kolejny miłośnik mądrości zauważy, że izba jest konstruktem, dyskursem lub narracją, a jego uczeń, że chemia to literatura. Są to w końcu tylko różne - mniej lub bardziej ostre - objawy tej samej choroby.

\section{Moce przyczynowe jako miara istnienia}

Pisaliśmy dotąd o grzechach filozofii analitycznej, pora wspomnieć o zasługach. Otóż wiele wskazuje na to, że filozofia analityczna właśnie wyzwala się z lingwistycznej ideologii. Wśród filozofów analitycznych jest coraz mniej filozofów 
języka, a coraz więcej filozofów umysłu. Ci ostatni z kolei coraz rzadziej piszą o zobowiązaniach ontologicznych, a coraz chętniej i częściej - o mocach przyczynowych (Fodor 1987; Searle 1994, 1997; Kim 2002; Dennett 1991). Wydaje się, że mamy do czynienia z kolejnym zwrotem w kwestii istnienia. Dla wielu współczesnych filozofów umysłu istnieć, to tyle i tylko tyle, co posiadać moce przyczynowe. Cóż to jednak takiego owe moce przyczynowe? Definicji nie podamy; nigdzie jej nie znaleźliśmy. Możemy jednak udzielić obszernych wyjaśnień.

\subsection{Próba dokładniejszego określenia pojęcia mocy przyczynowych}

Pojęcie mocy przyczynowych należy do najczęściej i najchętniej używanych przez współczesnych filozofów umysłu. Pojęcie to często jest wyjaśniane za pomocą odpowiednio dobranych przykładów. My również posłużymy się tą metodą. Nim podamy przykłady i wyjaśnimy, w czym rzecz, wpierw poczynimy kilka bardziej ogólnych uwag.

Dla wielu współczesnych filozofów umysłu istnieć to tyle, co posiadać moce przyczynowe. Jeżeli coś (wszystko jedno co) nie posiada żadnych mocy przyczynowych, to po prostu nie istnieje. Tak więc krasnoludki i satyry nie istnieją, bo nie posiadają żadnych mocy przyczynowych. Natomiast biurko, przy którym właśnie siedzę istnieje, bo posiada wcale liczne moce przyczynowe.

Pojęcie mocy przyczynowych jest tak ważne dla współczesnych filozofów umysłu dlatego, że odgrywa kluczową rolę w rozważaniach dotyczących tzw. przyczynowania mentalnego. Stany umysłu, np. przekonania i pragnienia, istnieją pod warunkiem, że posiadają odpowiednie moce przyczynowe. Jeżeli ich nie posiadają, to z metafizycznego punktu widzenia są fikcją, taką samą jak krasnoludki i satyry.

Czymże jednak są owe moce przyczynowe? Nim przejdziemy do współczesnych wyjaśnień i współczesnych przykładów, wspomnimy wpierw o Arystotelesie. Otóż sądzimy (niech historycy idei rozstrzygną, czy słusznie), że pomysłodawcą tego pojęcia był właśnie Arystoteles. Filozof ten odrzucał Platońskie formy idealne właśnie $z$ tego powodu, że nie posiadają żadnych mocy przyczynowych. Arystoteles nie posługiwał się określeniem moce przyczynowe, ale sądził, że istnieje to, co działa i (lub) podlega działaniu (Arystoteles 2003). Idea wyrażona zdaniem zaznaczonym kursywą stanie się punktem wyjścia dla dalszych wyjaśnień.

Zauważmy na początek, że Arystotelesowskiej recepcie na istnienie łatwo można nadać formę definicji przez indukcję. Aby uprościć wyjaśnienia, pominiemy spójnik „i”. Otrzymamy w ten sposób następującą formułę:

\section{(A) $X$ istnieje, o ile $X$ działa na pewien istniejący $Y$ lub podlega działaniu ze strony istniejącego Y-eka.}

Powyższa formuła odwołuje się do pojęcia działania, które kojarzy się z tzw. zachowaniem podmiotowym, które z kolei nie ma nic wspólnego z obiektami, ta- 
kimi jak biurka. Nie przejmujmy się tym na razie. Nasze wyjaśnienia zyskają na przejrzystości, jeżeli - póki co - zachowamy ideę działającego podmiotu. Wzmocnimy ją nawet, dokonując na naszej formule modyfikacji polegającej na zastąpieniu działania samą możnością działania. Ostatecznie otrzymamy:

(B) $X$ istnieje, o ile X-em można oddziałać na pewien istniejący Y lub istniejącym Y-ekiem można oddziałać na $X$.

Aby powyższy przepis mógł zacząć funkcjonować, niezbędna jest baza indukcyjna. Przynajmniej o jednym obiekcie trzeba przyjąć, że istnieje. Wybór jest ogromny. Nie bądźmy zbyt wybredni. Załóżmy, że punktem wyjścia, swoistą bramą do istnienia uczynimy jakiś bardzo zwykły obiekt, np. długopis, który leży przede mną w tej chwili na biurku. Tak więc dogmatycznie zakładamy, że wspomniany długopis istnieje. Czy istnieje biurko, przy którym siedzę? Oczywiście - tak. Mogę przecież oddziałać długopisem na biurko. Mogę np. zrobić na nim za pomocą długopisu rysę. $Z$ tego samego powodu istnieje koszula, w którą jestem ubrany, stuzłotowy banknot w prawej kieszeni mojej marynarki, ściany pokoju, w którym się znajduję. Na szklanym wazonie nie mogę, co prawda, zrobić rysy, ale mogę oddziałać nań za pomocą długopisu w inny sposób, a więc wazon też istnieje itd., itd. Zbiór przedmiotów, które (w myśl powyższej definicji) istnieją gwałtownie się powiększa. Jeżeli na pewne obiekty nie mogę oddziałać (tu i teraz) bezpośrednio długopisem, takie jak np. obecny prezydent USA lub, powiedzmy, księżyc, to $w$ każdym razie istnieją dobre racje, aby utrzymywać, że w zasadzie takie oddziaływanie jest możliwe. Jeżeli bezpośrednie oddziaływanie długopisem nie jest nawet w zasadzie możliwe, to mogę odwołać się do innych obiektów, o których wcześniej, posługując się warunkiem (B) i długopisem uznałem, że istnieją. Oto kilka przykładów. Fale elektromagnetyczne są niewrażliwe na manipulacje wykonywane długopisem i na odwrót. Wszelako radioodbiorniki są wrażliwe na działanie fal elektromagnetycznych, a na radioodbiorniki z kolei mogę podziałać długopisem, a więc i fale elektromagnetyczne istnieją. Czy istnieją fale mózgowe? O ile wiem, za pomocą fal mózgowych (via odpowiednie artefakty) można wpływać na zachowania komputera, a na komputer już mogę oddziałać długopisem. Bakterie i wirusy istnieją, bo działają na nie odpowiednie tabletki, na które z kolei mogę działać długopisem. Cząsteczki elementarne istnieją, bo oddziałują na odpowiednie artefakty, na które mogę podziałać np. łomem, a na łom długopisem itd., itd. Długopis + warunek (B), to bardzo potężne narzędzia. Posługując się tym narzędziem dostatecznie długo i dostatecznie wytrwale, odtworzylibyśmy cały materialny świat.

A co nie istnieje? W myśl przedstawianej koncepcji, nie istnieją byty, które nie posiadają żadnych mocy przyczynowych, czyli takie, na które niczym (co istnieje) nie można podziałać ani nimi na nic (co istnieje) nie można podziałać. Mówiąc bardziej obrazowo: nie istnieją te byty, które w żaden sposób nie zazębiają się (poprzez oddziaływania) z jakimkolwiek fragmentem fizycznego świata (czyli świata, który jest spojony poprzez możliwość wzajemnych oddziaływań). Dokonamy teraz przeglądu obiektów, które - w myśl przedstawionej koncepcji - nie 
istnieją. Nim się tym zajmiemy, krótka uwaga. Otóż, pomimo tego, że większość współczesnych filozofów umysłu zgadza się z przedstawioną tu koncepcją tego, co realne, rzeczywiste lub co naprawdę istnieje, to ich poglądy na temat tego, co naprawdę istnieje różnią się w przypadku wielu obiektów. Przegląd nasz rozpoczniemy od obiektów, które nie wywołują żadnych poważnych sporów.

A więc, oczywiście, krasnoludki, nimfy, satyry... i wiele innych mitycznych istot nie istnieje, bo nie posiada żadnych mocy przyczynowych. Nie można na krasnoludki podziałać długopisem, ani falami elektromagnetycznymi, ani czymkolwiek, i na odwrót.

Weźmy teraz pod uwagę nobliwy ze względów historycznych, ale łatwy do analizy przykład. Czy istnieją byty, zwane od czasów Platona formami idealnymi lub ideami? Oczywiście - nie, bo nie posiadają żadnych mocy przyczynowych. Konkretnym indywidualnym słoniem można oddziałać na wiele różnych materialnych rzeczy i wieloma materialnymi rzeczami można oddziałać na konkretnego indywidualnego słonia, ale formą słonia na nic oddziałać nie można, ani na formę słonia nie można niczym oddziałać. Podobnie mają się sprawy z bytami określanymi takimi mianami, jak: kulistość jako taka, gładkość sama przez się itd., itd. Kulistość konkretnej kuli posiada konkretne moce przyczynowe, gdyż można na nią działać i nią można działać, ale kulistość jako taka lub sama w sobie lub sama przez się jest pozbawiona jakichkolwiek mocy przyczynowych, a więc nie istnieje. Sądzę, że jest zupełnie jasne, dlaczego Arystoteles odmawiał prawa do istnienia tego rodzaju bytom. Nie działają ani nie podlegają działaniu.

Aby ułatwić sobie dalsze spekulacje dotyczące mocy przyczynowych, wspomóc wyobraźnię i nadać nieco wyraźniejszy kształt naszym intuicjom, wprowadzimy teraz w krąg rozważań coś, co w dalszym ciągu nazywać będziemy (być może niezbyt zręcznie) heurystycznym pogotowiem. Otóż rozwijana właśnie koncepcja istnienia opiera się w oczywisty sposób na inżyniersko-technicznych intuicjach. Forma sznurka nie nadaje się do tego, aby posłużyć się nią do budowy pewnej konkretnej maszyny; konkretny sznurek może zostać wykorzystany. Zębatość jako taka nie przyda się inżynierom do niczego; zębatość konkretnej zębatki zazębia się natomiast o zębatość innej konkretnej zębatki i w oczywisty sposób wpływa na funkcjonowanie tej oto konkretnej maszyny. W związku z tym, w wątpliwych przypadkach proponujemy posłużyć się następującym:

(HP) Będziemy przyjmować, że pewne X (obiekt, własność, relacja lub cokolwiek) posiada moce przyczynowe, jeżeli potrafimy wyobrazić sobie maszynę (urządzenie, system itd.) taką, że za pomocą X-a można byłoby wpłynąć na działanie tej maszyny Jeżeli natomiast nie potrafimy sobie wyobrazić takiej maszyny, to będziemy przyjmować (wstępnie i na próbę, do momentu, gdy ktoś lub coś nie przekona nas, że jest inaczej), że pewne $X$ nie posiada mocy przyczynowych.

(HP) ma wiele wad, ale posiada też liczne zalety, które niebawem wykorzystamy. Najlepiej będzie, jeśli pokażemy, jak należy się posługiwać (HP). 


\subsection{Moce przyczynowe a pieniądze}

Na początek weźmy pod uwagę ulubiony przykład filozofów wyjaśniających pojęcie mocy przyczynowych. Przykładem tym są pieniądze. Otóż w prawej kieszeni mojej marynarki znajduje się stuzłotowy banknot. Obiekt ten posiada wiele różnych własności, a mianowicie całkiem określony kształt, masę, fakturę, a jego powierzchnia pokryta jest z obu stron bardzo precyzyjnie wykonanymi malowidłami itd., itd. Wszystkim tym własnościom odpowiadają określone moce przyczynowe. Całkiem łatwo można wyobrazić sobie maszynę (a nawet nie musimy sobie niczego wyobrażać, gdyż takie maszyny już istnieją), która „rozpoznawałaby" wszystkie te własności. Innymi słowy każdą z tych własności można wpłynąć na działanie takiej maszyny. Na tym jednak nie koniec. Obiekt ten mógłbym np. spalić, wywołując w ten sposób wzrost temperatury w jego najbliższym otoczeniu i w ten sposób wpłynąć na działanie pewnej maszyny itd., itd. Moce przyczynowe owego banknotu są bogatsze niż jakikolwiek język i dlatego nie sposób ich wyliczyć ani skatalogować. Moce te są jednak wyraźnie ograniczone. Obiekt ten nie jest w stanie zatopić okrętu, zmienić biegu planet, a spalony nie spowoduje istotnego wzrostu temperatury w sąsiednim pokoju. Nie tkwią w nim takie moce.

Przejdźmy teraz do najważniejszej kwestii. Otóż o owym obiekcie zwykło się również powiadać, że posiada całkiem określoną wartość, a mianowicie jest pieniądzem i jest wart sto złotych. Otóż sądzę, że jest zupełnie jasne, że za tymi określeniami nie kryją się żadne dodatkowe moce przyczynowe. (HP) nie pozostawia co do tego żadnych wątpliwości. Nie jesteśmy sobie w stanie wyobrazić maszyny, na którą wpływ miałyby własność bycia pieniądzem lub własność bycia wartym sto złotych. Ktoś mógłby zaoponować. Istnieją przecież maszyny, które bez kłopotu rozpoznają stuzłotowe banknoty. Oczywiście - istnieją. Rozpoznają one jednak te obiekty nie po tym, że są one pieniędzmi, ani po tym, że są warte sto złotych, ale po unikalnej kombinacji własności (bardzo trudnej do podrobienia), za którą kryją się już określone moce przyczynowe.

Przykład z pieniędzmi jest dla badaczy zajmujących się mocami przyczynowymi, jako się rzekło, sztandarowy. Pieniądze budzą jednak nie tylko filozoficzne namiętności. Zawodowo zajmują się nimi rzesze finansistów i ekonomistów, a w życiu większości ludzi odgrywają zupełnie zasadniczą rolę. Dla pieniędzy, bywa, popełnia się zbrodnie, a krachy finansowe doprowadzają do ruiny rzesze zwykłych obywateli itd., itd. Jak to wszystko pogodzić z faktem, że maszyny są całkowicie nieczułe na ich wartość? Przykład z pieniędzmi jest tak uderzający, że warto poświęcić mu nieco więcej miejsca.

Powiada się często, że pieniądzem jest wszystko to, co pełni funkcję pieniądza i że w związku z tym bycie pieniądzem jest typową własnością funkcjonalną lub, jak niektórzy wolą mówić własnością drugiego stopnia, która może mieć wiele tzw. realizatorów. W rozważaniach dotyczących pieniędzy podkreśla się również często ich relacyjny lub względny charakter; to, co jest pieniądzem w obrębie określonej wspólnoty, nie jest już nim w obrębie innej itd. Wszystko to są dość oczywiste prawdy i nie warto się dłużej nad nimi rozwodzić. Mnie w fe- 
nomenie pieniędzy interesuje coś innego, coś, co - jak się wydaje - ma związek z tzw. problemem przyczynowania mentalnego. W filozofii (i nie tylko) często zdarza się tak, że rozważania dotyczące pewnej określonej dziedziny przynoszą nieoczekiwane korzyści teoretyczne w innych dziedzinach. Pospekulujmy jeszcze trochę o pieniądzach.

Na początek spróbujmy wyobrazić sobie przyszłą ewolucję pieniądza. Po pierwsze załóżmy, że wreszcie nastąpiło (postulowane przez wielu ekonomistów) ujednolicenie w skali całego świata waluty. Podstawową jednostką rozliczeniową jest jeden global, którego siła nabywcza odpowiada w przybliżeniu jednemu złotemu. Po drugie, wyobraźmy sobie, że wreszcie tzw. pieniądz elektroniczny wyparł całkowicie wszelkie jego inne postacie. Co za ulga! Wszelkiego rodzaju operacje, które wymagały dotąd pośrednictwa pieniędzy, a więc pośrednictwa obiektów o całkiem określonych fizycznych własnościach, zostają zastąpione poprzez dokonywanie niewielkich fizycznych zmian na twardych dyskach odpowiednich artefaktów. Załóżmy, że żyjemy w czasach, w których nikt już nie pamięta, jak wyglądał jeden głobal. Pieniądze nie kojarzą się już z niczym konkretnym, a określenia: góra pieniędzy, brzęcząca moneta czy luby szelest banknotów stały się niezrozumiałe. Fenomenologia pieniędzy zmieniła się całkowicie. Przyjmijmy dalej, że w imię zabezpieczenia systemu przed atakami hakerów i w imię lepszej kontroli nad stanem światowych operacji finansowych wszystkie operacje, transakcje, zakupy itd. zapisywane są na jednym i tym samym dysku i tylko na nim. Jest to oczywiście sztuczne założenie i pachnie science-fiction. Zauważmy jednak, że gdyby tak postąpiono i gdyby trwałość tego dysku i trwałość zapisanych tam danych była niezawodna, to cały system finansowo-ekonomiczny funkcjonowałby tak, jak przedtem. Posuńmy się jeszcze w naszych fantazjach nieco dalej i załóżmy, że w imię zwiększenia bezpieczeństwa dysk, o którym mowa zostaje przeniesiony na Marsa i tam czuwa nad nim starannie wyselekcjonowane zespół finansistów.

Minimalne fizyczne zmiany zachodzące na tym krążku posiadają kolosalny wpływ (via informacje przesyłane na Ziemię przez strażników) na zachowania Ziemian. Miliardy ludzi każdego dnia w napięciu oczekują wiadomości nadchodzących z Marsa. Jakież to znowu zmiany dokonały się na Marsjańskim krążku? Niekiedy stan krążka wywołuje na Ziemi kryzys. Zamykane są zakłady pracy, miliony ludzi lądują na bruku; inni tracą dorobek całego życia; niektórzy popełniają samobójstwa itd., itd.

Spójrzmy teraz na scenariusz przedstawiony w poprzednich akapitach chłodnym okiem filozofa naturalisty i spróbujmy dokonać czegoś w rodzaju wstępnej naturalizacji pieniędzy. Mamy bardzo ułatwione zadanie, gdyż cały system finansowy skupiony jest w jednym miejscu, na niewielkim krążku o promieniu kilku centymetrów. Zapewne nie przeprowadzimy pełnej naturalizacji, ale możemy poczynić kilka prostych spostrzeżeń. Otóż, po pierwsze, fizyczny stan krążka jest bez znaczenia i sam przez się nie jest w stanie powodować żadnych zmian w zachowaniach Ziemian. Ten punkt wydaje się całkiem oczywisty. Co zatem wywiera ten wpływ? Odpowiedź znowu wydaje się oczywista. Wpływ ten wywiera wyłącznie wiedza Ziemian o tym, że aktualny stan krążka jest właśnie taki, a nie inny. Posługując się modną obecnie terminologią, można byłoby rzec, że system finansowy 
superweniuje na stanie umysłów Ziemian. Nasuwa się w związku z tym pytanie, co byłoby, gdyby stan umysłów Ziemian zaczął odbiegać w mniejszym lub większym stopniu od rzeczywistego stanu krążka? Nie ulega wątpliwości, że istnieją takie stany umysłów, które sprzyjają rozwojowi gospodarczemu i takie, które go spowalniają, a nawet powodują kryzysy. Innymi słowy, pytamy, co by się stało, gdyby strażników-finansistów zastąpili psycholodzy-manipulatorzy (oczywiście bez wiedzy Ziemian), którzy przekazywaliby na Ziemię same odpowiednie wiadomości, tzn. takie, które sprzyjają rozwojowi gospodarczemu. Możliwe są tutaj różne odpowiedzi. Wolelibyśmy jednak, aby udzielali ich ekonomiści.

\subsection{Niektóre stare filozoficzne spory i moce przyczynowe}

Spróbujmy przyjrzeć się bardzo staremu sporowi pomiędzy nominalizmem i realizmem. Spór ten ma wiele płaszczyzn i postaci. Zajmiemy się niektórymi. Weźmy pod uwagę stanowisko Arystotelesa. Filozof ten utrzymywał, że formy indywidualne tkwią w konkretnych indywidualnych rzeczach i że konkretne indywidualne rzeczy tworzą dzięki temu tzw. gatunki naturalne. (Arystoteles 2009 ks. 7) I tak np., jeżeli weźmiemy pod uwagę dwa psy, to niezależnie od tego, jak bardzo byłyby różne (pierwszy duży, drugi mały; pierwszy biały, drugi czarny itd.), to jest coś takiego, co w obu tych obiektach jest takie samo, coś, co można byłoby nazwać formą psa. Otóż w obu psach tkwi jedna i ta sama forma psa, która sprawia, że zwierzęta te należą do całkiem określonego gatunku. Nazwijmy tę formę psowatością. Można zatem rzec, że w każdym psie tkwi psowatość, która sprawia, że zwierzę to należy do tego właśnie gatunku. Zadajmy sobie teraz następujące pytanie: Czy psowatość posiada moce przyczynowe? Pytanie nasze można przeformułować na następujące: Czy istnieje coś, powiedzmy pewne $X$, które jest wspólne wszystkim psom, tylko psom i posiada określone moce przyczynowe? Jak to rozstrzygnąć? Proponujemy następujące kryterium. Jeżeli potrafimy wyobrazić sobie maszynę, która bezbłędnie odróżnia psy od wszelkich innych obiektów, to odpowiedź jest pozytywna. Oczywiście maszyna taka jest możliwa i z jej skonstruowaniem nie byłoby specjalnych kłopotów. Psy posiadają unikalny kod genetyczny i odpowiednie artefakty potrafią jednoznacznie rozstrzygnąć, czy jest on właśnie taki. Łatwo można sobie wyobrazić „bramkę”, która jest wrażliwa na ten i tylko ten kod i która na drugą stronę przepuszcza psy i tylko psy.

Nietrudno zauważyć, że to, co jest prawdą o psach, jest prawdą również o innych tzw. gatunkach naturalnych: Iwach, słoniach, ludziach itd. Nietrudno również zauważyć, że w analogiczny sposób można poradzić sobie ze wszystkimi substancjami chemicznymi. Tak więc można powiedzieć, że różne próbki wody posiadają wspólną formę i że forma ta posiada określone moce przyczynowe.

Weźmy teraz pod uwagę np. termin student. Czy istnieje coś takiego, co jest wspólne wszystkim studentom i tylko studentom i posiada określone moce przyczynowe? Innymi słowy, czy jesteśmy w stanie skonstruować czysto fizyczne urządzenie, które będzie rozpoznawać studentów? Odpowiedź, i wydaje się 
to oczywiste, jest negatywna. To samo jest prawdą w odniesieniu do wielu innych terminów socjologicznych, takich jak pediatra, ksiądz, prokurator itd. Czy to znaczy, że nie ma studentów? Oczywiście, że są. Różnica pomiędzy terminami, takimi jak tygrys, słoń, wieloryb itd. - z jednej strony i takimi jak student, ksiądz, prokurator $-z$ drugiej polega na tym, że tygrysowatość, słoniowatość, wielorybowatość itd. tkwią w indywidualnych obiektach; nikt natomiast nie jest studentem, księdzem czy prokuratorem ze względu na swe wewnętrzne własności. Aby być studentem, trzeba pozostawać w pewnych relacjach do innych ludzi i do określonych instytucji.

A co z takimi pojęciami jak przystojny mężczyzna, atrakcyjna kobieta itd.? Korzystając z Wittgensteinowskiego żargonu mówimy, że są to typowe pojęcia familijne. Skonstruowanie maszyny, która przepuszczałaby na drugą stronę bramki tylko przystojnych mężczyzn lub tylko atrakcyjne kobiety byłoby bardzo trudne (być może niemożliwe), nie byłoby to jednak przedsięwzięcie całkowicie pozbawione widoków powodzenia i w jakiejś mierze wykonalne. Rzecz w tym, że przystojność tkwi w przystojnych mężczyznach, podczas gdy studenckość nie tkwi w studentach.

Aby zarysować różnicę pomiędzy tymi trzema rodzajami pojęć i uwypuklić odmienność ich zazębiania się ze światem i, co za tym idzie, ich sposób użycia, posłużmy się prostym przykładem. Pewien X może skutecznie przez całe życie udawać księdza, nawet jeśli nim nie jest; nieporównanie trudniej jest udawać przystojnego mężczyznę, o ile nie posiada się odpowiedniej aparycji; udawanie tygrysa czy wieloryba jest natomiast zupełnie niemożliwe.

Prowadząc zajęcia ze studentami biologii dowiedziałem się, że istnieje coś takiego, co jest wspólne wszystkim samcom i tylko samcom. To samo jest prawdą o samicach. Tak więc można byłoby skonstruować bramkę, która na drugą stronę przepuszczałaby samców i tylko samców; niezależnie od tego, czy byłby to samiec słonia, tygrysa, myszy, pszczoły... czy człowieka. To samo, rzecz jasna, jest prawdą o samicach.

Nieco science fiction. Załóżmy, że szalony antyklerykał z odległej planety planuje wysłanie na Ziemię terminatora, którego zadaniem byłoby uśmiercenie wszystkich księży i tylko księży. Niezależnie od tego jak bardzo byłby się starał, zadanie takie byłoby niewykonalne.

Gdyby szalona feministka chciała wysłać na Ziemię terminatora z zadaniem unicestwienia wszystkich samców i tylko samców, to - o ile dysponowałaby odpowiednią wiedzą i odpowiednimi środkami technicznymi - zadanie takie byłoby (w zasadzie) wykonalne.

Zauważmy przy okazji, że przedstawiciele nauk przyrodniczych są z reguły (i dodajmy, że spontanicznie) realistami, a socjolodzy - nominalistami. Długo by o tym pisać.

Zajmijmy się teraz nieco innymi przypadkami, przez cały czas mając na uwadze moce przyczynowe. Weźmy pod lupę język i rozpocznijmy od rzeczy najprostszych. Przypomnijmy wpierw kilka prostych i łatwych do uchwycenia rozróżnień. Otóż, gdy mowa o zdaniach (np. zdaniach języka polskiego), to zwykło się odróżniać pomiędzy zdaniami, egzemplarzami zdań i ich znaczeniami. Spójrzmy na 
te byty pod kątem mocy przyczynowych. Aby ułatwić sobie dalsze rozważania, weźmy pod uwagę konkretne zdanie języka polskiego, np. Ala ma kota. Ano właśnie... To, co wzięliśmy pod uwagę nie jest zdaniem, ale pewnym jego egzemplarzem. Innym egzemplarzem jednego i tego samego zdania byłby napis ala ma kota, jeszcze innym Ala ma kota itd. Zdanie jest jedno, a egzemplarzy wiele. Praktycznie nieograniczona liczba. Nie można fizycznie wytworzyć zdania, to co wypisuję, to egzemplarze i tylko egzemplarze tego zdania. Egzemplarze zdania to konkretne materialne obiekty, mające określone moce przyczynowe. Zdania natomiast to byty platońskie pozbawione mocy przyczynowych. Stosunek zachodzący pomiędzy zdaniem a jego egzemplarzami przypomina stosunek zachodzący pomiędzy indywidualnymi, konkretnymi tygrysami a ideą lub formą tygrysa. Ustaliliśmy wcześniej, że tygrysy tworzą gatunek naturalny, czyli, że istnieje coś takiego, co jest wspólne wszystkim tygrysom i tylko tygrysom i posiada określone moce przyczynowe; czyli, że można byłoby skonstruować czysto fizyczne urządzenie, które bezbłędnie rozpoznawałoby tygrysy. Nasuwa się w związku z tym pytanie, czy można byłoby skonstruować czysto fizyczne urządzenie, które bezbłędnie rozpoznawałoby egzemplarze jednego i tego samego zdania. Innymi słowy pytamy o to, czy egzemplarze jednego i tego samego zdania tworzą gatunek naturalny $\mathrm{w}$ arystotelesowskim sensie. W przypadku tygrysów ustaliliśmy, że czymś takim mógłby być unikalny kod genetyczny. Egzemplarze zdań nie posiadają jednak kodu genetycznego. Nasuwa się pytanie, czy istnieje coś, co mogłoby w tym przypadku odegrać rolę kodu genetycznego. Naturalną kandydaturą wydaje się w tym przypadku to, co logicy zwykli nazywać syntaksą czyli kształt i kolejność znaków jakiegoś ustalonego alfabetu. Zrazu sprawa wydaje się dość prosta, ale wystarcza chwila, aby uświadomić sobie, że tak nie jest. Cóż to znaczy, że dwa znaki są takiego samego kształtu? Przychodzi tu na myśl cała gama różnych przekształceń geometrycznych, z których żadne nie wydaje się tym właściwym. Również pojęcie kolejności znaków wydaje się wysoce nieprecyzyjne. Czy chodzi o kolejność w przestrzeni czy w czasie; czy odstępy pomiędzy poszczególnymi znakami mogą być dowolnie duże; czy same znaki mogą być różnej wielkości, a przy tym nie wszystkie takiej samej itd. Jeżeli dodamy, że znaki mogą zostać wykonane w bardzo różnym materialnym tworzywie, to pozytywna odpowiedź na pytanie o moce przyczynowe zaczyna być coraz bardziej wątpliwa.

Dlaczego z tygrysami się udaje, a z egzemplarzami określonego zdania jest tak trudno? Proponujemy następującą odpowiedź. W przyrodzie jest skończona i niewielka liczba tygrysów i, na dodatek, wszystkie „wykonane” są z tego samego. Inaczej sprawy się mają z egzemplarzami pewnego określonego zdania. Tym razem punktem wyjścia jest pojęcie, chciałoby się rzec - idea egzemplarzy określonego zdania. Urzeczywistniając tę ideę, jesteśmy ograniczeni tylko własną wyobraźnią i treścią pojęcia, która w praktyce okazuje się niesłychanie elastyczna; posiadamy nieomal boską moc tworzenia kolejnych, coraz bardziej dziwacznych egzemplarzy. Załóżmy przeto, że bierzemy pod uwagę tylko te napisy zdania, którego jednym z egzemplarzy jest Ala ma kota, które zostały wytworzone pomiędzy rokiem 1940 a 1950. W tym przypadku zapewne poradzilibyśmy sobie i skonstruowanie odpowiedniej maszyny byłoby możliwe, a nawet proste. Gdyby 
napisy kształtu Ala ma kota były składnikiem ożywionej przyrody i występowały w skończonej liczbie, zapewne uznalibyśmy je za gatunek naturalny.

Powróćmy na moment do tygrysów i przenieśmy się w przyszłość. Załóżmy, że inżynieria genetyczna rozwinęła się niesłychanie. Swobodnie operujemy dostępnym materiałem genetycznym, tworząc najbardziej wymyślne hybrydy. Zapewne pojawiłby się problem, czy wytworzone właśnie organizmy $X$ są jeszcze tygrysami.

Dlaczego jednak aż tyle miejsca poświęcamy napisom? Odpowiedź na to pytanie brzmi jak następuje. Napisy są ściśle powiązane z tzw. obliczeniową teorią umysłu. Poświęćmy tej kwestii kilka uwag. Otóż powiada się często, że komputery są maszynami przetwarzającymi symbole. Symbole, o które chodzi, to 0 i 1. Mówiąc w skrócie i uproszczeniu, komputer to maszyna, która zgodnie z pewnymi instrukcjami (zwanymi programem) przyporządkowuje ciągom zer i jedynek inne ciągi zer i jedynek. Czym są jednak zera i jedynki? Otóż, powiada się, mogą one być czymkolwiek; mogą to być dwa dowolne (ale ustalone) stany rzeczy, wydarzenia, obiekty itd. Ważne jest, aby można je było rozpoznawać i aby były ustalone. Poza tym ich własności fizyczne mogą być dowolne. Koncept ten często wyraża się powiadając, że komputer można zrobić z czegokolwiek, albo - nieco inaczej - że w przypadku obliczeń nie jest ważny hardware, a liczy się tylko software. Nie jest ważne, w jakim tworzywie urzeczywistniane są obliczenia i nie jest ważne, jakiego rodzaju bytami są zera i jedynki. Na samą istotę procesu obliczeniowego nie ma to żadnego wpływu. Porzućmy na razie ten wątek i przenieśmy się w nieco inne rejony.

\subsection{Umys jako software i moce przyczynowe}

Sztandarowa metafora obliczeniowej teorii umysłu brzmi jak następuje: Umysł pozostaje $w$ takim stosunku do mózgu, jak program do twardych części komputera. Nim zajmiemy się dokładniejszą analizą tej idei, zauważmy, że na pewnym poziomie analizy jest ona niesłychanie sugestywna i powstaje spontanicznie. Spróbujmy przez pewien czas myśleć tak, jak myślą zwolennicy koncepcji, którą John Searle ochrzcił mianem mocnej wersji sztucznej inteligencji. (Searle 1995; po raz pierwszy opublikowane w 1980)

Po ponad dwóch tysiącach lat spekulacji wreszcie udało się odkryć, czym jest to, co zwykło się nazywać duszą. Podobieństwa zachodzące pomiędzy własnościami przypisywanymi duszy a tym, co zwie się programem są liczne i uderzające.

Po pierwsze, dusza nie jest dostępna dla ludzkich zmysłów, nie można jej ujrzeć, dotknąć, posmakować itd. I tak samo jest z programem komputerowym.

Po drugie, ciało ludzkie, które opuściła dusza zmienia się w kupę mięsa. "Ciało komputera”, w którym skasowano wszystkie programy zmienia się w kupę żelastwa.

Po trzecie, jeśli chcemy przewidzieć zachowania pewnego człowieka, to na nic zda się ważenie, mierzenie, badanie składu chemicznego - wszystko to są 
rzeczy bez znaczenia. Jeżeli chcemy wiedzieć, jak zachowa się pewien człowiek w pewnej sytuacji, co zrobi, co powie itd., to trzeba wniknąć w głąb jego duszy, poznać jego ukryte myśli, zamiary, przekonania itd. Jeżeli chcemy przewidzieć, jak zachowa się pewien komputer, to na nic zda się ważenie, mierzenie, badanie składu chemicznego - trzeba znać jego duszę, czyli oprogramowanie.

Po czwarte, łatwo można sobie pomyśleć dwoje ludzi całkowicie różnych pod względem fizycznym, ale identycznych psychologicznie, obdarzonych niejako taką samą duszą. To samo da się powiedzieć o programach i komputerach.

Po piąte, jeżeli przyjmiemy, że program to dusza, to marzenie-fantazja wyrażane $w$ wierzeniach religijnych, mitach, baśniach, a mianowicie wędrówka dusz staje się w pełni realne. Programy wszak można swobodnie przenosić z nośnika na nośnik. Fizyczny koniec pewnego dysku nie musi oznaczać końca programu, który był na nim zapisany; można go w odpowiednim momencie przenieść na inny nośnik. Jeżeli jest to możliwe w przypadku programu, a dusza to program, to jest to, przynajmniej w zasadzie, możliwe również w przypadku duszy. Związek programu-duszy z mózgiem w roli nośnika nie jest koniecznością. Dusza-program równie dobrze mogłaby się ucieleśnić w wielu innych, odpowiednio zorganizowanych materialnych tworzywach.

Naszkicowany powyżej sposób myślenia upowszechnił się niezmiernie i, rzec można, zszedł „pod strzechy”. Idea, która u swych początków była domeną spekulacji filozofów, stała się ważnym elementem potocznych przeświadczeń wielu ludzi, zwłaszcza młodych. Przemiana ta dokonała się tyle za sprawą coraz doskonalszych elektronicznych gadżetów, ile twórczości filmowej z gatunku science fiction. Roboty wyposażone w odpowiednie programy widzą, słyszą, myślą i... coraz częściej również cierpią. Niesforne dzieci (w kreskówkach), zbyt długo oddające się rozkoszom gier komputerowych, są „wciągane” na twardy dysk swego komputera i stają się jedną z wirtualnych postaci. Nie jest ważny hardware, liczy się tylko software. Wędrujący plik umysłu to nieomal idea zdrowego rozsądku wśród konsumentów gier komputerowych, elektronicznych gadżetów i twórczości science fiction itd., itd. Wiarygodności omawianej koncepcji przydaje szybki postęp w świecie cybergadżetów. Elektroniczne artefakty są coraz doskonalsze i w coraz większym stopniu kompatybilne z użytkownikami. Nikogo już nie dziwią ani cybernetyczne ręce, którymi można się posługiwać, wykorzystując to, co zwykło się nazywać myślą, aktem woli, ani komputery przystosowane do użytku dla ludzi całkowicie sparaliżowanych. Skoro tzw. myśl staje się kompatybilna z odpowiednio oprogramowanym artefaktem, to czym innym mogłaby być, jak nie programem realizowanym w biologicznej tkance? Naturalne pytanie, które się narzuca brzmi: Gdzie są granice mojego ciała?! Czy mogę potraktować cybernetyczną rękę jako swoją? Jeżeli mogę wpływać za pomocą tzw. myśli na artefakty, to zapewne mogę też za pomocą artefaktów wpływać na tzw. myśli. 


\subsection{Moce przyczynowe raz jeszcze}

Pisałem wcześniej o lingwistycznym zwrocie w kwestii istnienia. Podejście, które teraz staramy się opisać, można byłoby określić mianem technologicznego zwrotu w kwestii istnienia. Pojęcie mocy przyczynowych jest, wydaje się, filozoficzną reakcją na rewolucję techniczną, a zwłaszcza na rozwój badań nad tzw. sztuczną inteligencją. Jedną z przyczyn załamywania się lingwistycznej ideologii jest właśnie fakt, iż język, do niedawna miara wszechrzeczy, sam znalazł się pod „ostrzałem". Zastanawianie się nad tym, w jaki sposób skonstruować artefakty naśladujące różne ludzkie zdolności poznawcze, w tym zdolność rozumienia języka, przywraca wielu filozofom poczucie rzeczywistości, także wówczas, gdy w grę wchodzi język i różne blisko z nim związane fenomeny.

Moce przyczynowe nie są uzależnione od naszych układów pojęciowych, języków i zobowiązań ontologicznych. Są one uzależnione tylko od tego, co rzeczywiście tkwi w otaczającym nas świecie. Odwołując się do mocy przyczynowych, przywracamy pojęciu istnienia jego pierwotny, absolutny charakter. Jest to jeden z powodów, dla których spory prowadzone przez współczesnych filozofów umysłu przybierają niekiedy postać dobrze znaną z dziejów filozofii. Dobrym przykładem jest tutaj spór prowadzony pomiędzy Johnem Searle'm a zwolennikami tzw. mocnej wersji sztucznej inteligencji. Jest to m.in. innymi spór o to, czy istnieje coś, co jest wspólne różnym fizycznym realizacjom jednego i tego samego programu. Spór ten można bardzo łatwo przetłumaczyć na język starodawnej filozofii jako spór o istnienie wspólnej formy. Searle byłby w tym sporze nominalistą, a np. Daniel Dennett zajmowałby stanowisko analogiczne do stanowiska Arystotelesa.

W pierwszej części tej pracy wprowadziliśmy określenie normalny realizm na oznaczenie stanowiska, wedle którego pojęciowa twórczość nie ma żadnego wpływu na świat; ani go nie tworzy, ani go nie zmienia. Normalny realizm - zaznaczmy to wyraźnie - nie jest stanowiskiem w sporze, który określaliśmy mianem drugiego sporu o istnienie świata. Normalny realista nie jest stroną $w$ tym sporze - odrzuca go w całości. Wydaje się nam zresztą, że wielu współczesnych filozofów umysłu, posługujących się pojęciem mocy przyczynowych, to właśnie normalni realiści.

Powróćmy na moment do rozważanego na pierwszych stronach tej pracy przykładu ze stwarzaniem izby. Filozof operujący pojęciem mocy przyczynowych powiedziałby zapewne: Pojęciowa twórczość ani nie stwarza izby, ani jej nie zmienia po prostu dlatego, że w wyniku tego rodzaju zabiegów nie zmieniają się moce przyczynowe izby. I byłby to właśnie normalny realizm.

Zauważmy na koniec, że pojęcie mocy przyczynowych zapewne razi niektórych filozofów analitycznych. Powód jest dobrze znany. Pojęcia przyczyny, związku przyczynowo-skutkowego, oddziaływania itd., wszystko to, można byłoby rzec, są pojęcia metafizyczne, wykraczające poza obserwację i doświadczenie. Wszak już David Hume wykazał, że zawsze i wszędzie obserwujemy tylko tyle, że po zjawisku typu A następuje zjawisko typu B. Mówiąc o oddziaływaniu, przyczynach, mocach przyczynowych itd. wzbogacamy doświadczenie o metafizyczną 
spekulację. Cóż na to można rzec? Nie jesteśmy w stanie rozważać tutaj różnych możliwych definicji pojęcia przyczyny i trudności z tym związanych. Ograniczymy się do jednej uwagi.

Otóż pojęcie przyczyny jest wbudowane w tyle innych pojęć, tak mocno zakorzenione w najbardziej nawet potocznym języku, że wyeliminowanie go jest teoretyczną mrzonką. Gdybyśmy chcieli być konsekwentni, musielibyśmy poddać obróbce takie, zdawałoby się, czysto opisowe wypowiedzi, jak np. Kot rozlał mleko lub Piotr skaleczył się nożem oraz wiele, wiele innych. Bardzo trudno byłoby cokolwiek powiedzieć, a jeszcze trudniej pomyśleć. Żyjemy w coraz bardziej stechnicyzowanym świecie, nieustannie uruchamiamy różne urządzenia i nieustannie wpływamy na nie w określony sposób i w dowolnym, wybranym przez nas momencie; ludzie sparaliżowani kontrolują swoje komputery i działają na nie za pomocą ruchów gałek ocznych, a są już tacy, którzy czynią to za pośrednictwem myśli (lub mózgu) itd., itd. Opisanie tego wszystkiego, lub choćby teoretyczne obmyślenie w Humowskim żargonie, bez powoływania się na przyczyny, działania, wpływy itd. prowadzi do absurdalnego obrazu; obrazu, w którym cały świat jest czymś w rodzaju filmu, a my sami, całkowicie bezwolne postacie, stanowimy jego część. 
Rozdział trzeci

\section{NATURALIZACJA OBRAZÓW I LUDZI (CZYLI KILKA WSPÓŁCZESNYCH TEORII UMYSŁU W SPOSÓB OBRAZOWY PRZEDSTAWIONYCH)}

Wyjaśniamy od razu, że mówiąc w tym rozdziale o obrazach, nie mamy na myśli żadnych umysłowych obrazów tylko zwykłe obrazy, malowane przez zwykłych artystów malarzy, takie, które wiszą na ścianach w muzeach.

Co jednak obrazy mają wspólnego z umysłem i w ogóle z ludźmi? Ludzie myślą, widzą, słyszą... zachowują się i działają, podczas gdy obrazy nie mają żadnego życia wewnętrznego i przez cały czas wiszą na ścianach. Wszystko to prawda, ale, o dziwo, gdy próbujemy naturalizować język, za pomocą którego opisujemy obrazy, napotykamy wiele problemów analogicznych do tych, z którymi zmagają się współcześni filozofowie umysłu. A ponadto - i warto to osobno podkreślić naturalizując opisy obrazów, można sformułować kilka stanowisk analogicznych do tych, które pojawiają się w sporach o naturę umysłu. Uznaliśmy, że jest to na tyle interesujące, że postanowiliśmy koncepcje te przedstawić w odniesieniu do obrazów i tylko obrazów. Odniesienie tych teorii do ludzi wymagałoby, co oczywiste, dokonania pewnych korekt, ale istota rzeczy pozostałaby taka sama.

\section{Naturalizacja obrazów}

\subsection{Dwa sposoby opisu, dwa języki, dwa rodzaje własności}

Proponuję, abyśmy na pewien czas przestali interesować się duchem i materią, a zamiast tego skupili na malarstwie. W dalszym ciągu będziemy się zajmo- 
wali stosunkiem zachodzącym pomiędzy predykatami malarskimi a predykatami fizykalnymi. Wprowadzone przed chwilą określenia uzyskają niebawem ściśle określony sens.

Weźmy pod uwagę arkusz białego papieru w kształcie kwadratu o boku długości $1 \mathrm{~m}$ i podzielmy równo na mniejsze kwadraty, z których każdy ma bok o długości $1 \mathrm{~mm}$. Kwadratów takich jest w sumie dokładnie milion. Załóżmy dalej, że istnieje 10 różnych barw i że każdy kwadracik o boku $1 \mathrm{~mm}$ jest w pełni fizycznie zdeterminowany poprzez zamalowanie go w określony sposób którąś spośród tych dziesięciu różnych barw. Oznaczmy barwy przy pomocy liczb 1,2,..10. (liczba 10 została wybrana ze względów rachunkowych; zamiast niej można wziąć jakąkolwiek inną, ale skończoną liczbę). Jeżeli w opisany sposób pokryjemy barwami wszystkie kwadraciki, to otrzymamy jeden konkretny obraz. Przez pełny fizyczny opis każdego obrazu rozumieć będziemy wskazanie dla każdego kwadratu którejś spośród dziesięciu różnych barw, która go pokrywa. Mówiąc innymi słowy, poprzez pełny fizyczny opis pewnego obrazu rozumieć będziemy matrycę kwadratową (macierz kwadratową) postaci [aij] taką, że i=j= 1,2,..1000; $a i j=1,2, \ldots 10$. Nasuwa się pytanie, ile jest matryc spełniających wyszczególnione warunki, czyli - innymi słowy - ile jest możliwych obrazów na arkuszu papieru o boku $1 \mathrm{~m}$, sporządzonych opisaną metodą. Aby uzyskać odpowiedź, trzeba liczbę 10 pomnożyć przez siebie milion razy. Gdybyśmy chcieli zapisać tę liczbę w systemie dziesiętnym, bez potęgowania, to byłaby to liczba zaczynająca się od jedynki, po której następowałoby milion zer. Zbiór wszystkich tych obrazów oznaczać będziemy przez ZO1.

Wyjaśniliśmy, co rozumiemy poprzez pełny opis fizykalny pewnego obrazu. Oczywiście każdy pełny opis fizykalny (będący po prostu konkretną matrycą, w której na każdym spośród miliona miejsc figuruje numer odpowiedniego koloru) jest zarazem wyrażeniem jednostkowym, tzn. odpowiada mu jeden i tylko jeden obraz. Ktoś dysponujący pełnym opisem fizykalnym każdego obrazu o boku $1 \mathrm{~m}$ dysponowałby zarazem pełnym opisem fizykalnym naszego mini- świata.

Wprowadzimy teraz pojęcie predykatu fizykalnego. Otóż przez predykat fizykalny rozumieć będę każdą matrycową charakterystykę. Oczywiście charakterystyka ta nie musi być pełna. Oto kilka przykładów:

$X$ jest takim obrazem, że (w odpowiadającej mu matrycy) a1j = 5 (tzn. takim, że w pierwszym wierszu znajdują się same liczby 5)

X jest takim obrazem, że (w odpowiadającej mu matrycy) suma każdych dwóch sąsiednich wyrazów w tym samym wierszu jest liczbą parzystą

X jest takim obrazem, że (w odpowiadającej mu matrycy) na głównej przekątnej znajdują się co najmniej dwie jedynki

X jest takim obrazem, że wyznacznik (odpowiadającej mu matrycy) jest liczbą parzystą 
Oczywiście każdej niepełnej charakterystyce odpowiada pewien ściśle określony zbiór obrazów. W dalszym ciągu każdy zbiór obrazów określony przez niepełną fizykalną charakterystykę nazywać będę fizykalnym gatunkiem naturalnym, a odpowiadającą mu własność lub cechę (którą odróżniamy od predykatu) - własnością lub cechą fizykalną. Tyle, jeśli chodzi o fizykalny opis naszego mini-świata. Przejdźmy do malarstwa.

Ponieważ nie jestem malarzem ani nawet ekspertem w tej dziedzinie, ograniczę swoje zainteresowania do tzw. malarstwa przedstawiającego. Otóż niektóre spośród naszych obrazów należących do zbioru ZO1 przedstawiają bitwy, inne uczty, jeszcze inne sceny pogoni, a jeszcze inne - sceny miłosne itd., itd. Ta prosta konstatacja skłania nas do wprowadzenia pojęcia predykatu malarskiego. Bardzo trudno byłoby podać definicję predykatu malarskiego. Sądzę jednak, że jest jasne, co mam na myśli. Oto kilka przykładów predykatów malarskich:

\section{X jest obrazem przedstawiającym bitwę}

\section{X jest obrazem przedstawiającym ucztę}

\section{X jest obrazem przedstawiającym egzekucję}

\section{X jest obrazem przedstawiającym scenę karmienia}

\section{X jest obrazem przedstawiającym scenę pożegnania}

Mówiąc krótko, przez predykaty malarskie chcę rozumieć wszystkie te predykaty, którymi skłonni bylibyśmy się posłużyć, wykonując następujące polecenie: Opowiedz, co przedstawia dany obraz.

W dalszym ciągu zbiór obrazów określony przez pewien predykat malarski będę nazywał gatunkiem malarskim, a cechę lub własność odpowiadającą temu predykatowi - cechą lub własnością malarską.

Przejdźmy teraz do kwestii, która nas tutaj interesuje najbardziej. Otóż nasz mini-świat złożony ze wszystkich obrazów (których liczba jest równa liczbie zawierającej milion zer) wykonanych w opisany wcześniej sposób na kwadratowym arkuszu papieru o boku $1 \mathrm{~m}$ może być opisywany na dwa sposoby - fizykalny bądź malarski. Nim zajmiemy się w sposób systematyczny związkami zachodzącymi pomiędzy tymi dwoma opisami, zwróćmy uwagę na pewne oczywiste różnice.

Po pierwsze, wszystkie predykaty fizykalne są tzw. terminami ostrymi (tzn. dowolny obraz należący do zbioru ZO1 albo znajduje się w polu orzekania predykatu fizykalnego, albo nie), podczas gdy wszystkie predykaty malarskie są tzw. terminami nieostrymi. Weźmy np. pod uwagę predykat X przedstawia bitwę. Otóż wydaje się, że istniałoby bardzo wiele obrazów należących do Z01, co do których mielibyśmy wątpliwości, czy należą do zakresu tego predykatu, tzn. czy jeszcze przedstawiają bitwę, czy już nie. Wolno nam chyba zaryzykować uogólnienie i stwierdzić, że to samo dotyczy pozostałych predykatów malarskich. 
Po drugie, o ile istnieje tzw. pełny opis fizyczny każdego obrazu należącego do ZO1, to, jak się wydaje, nie ma czegoś takiego, jak dający się w praktyce skonstruować pełny opis malarski. Niezależnie od tego, jak byśmy się starali i niezależnie od tego, jak długi (w granicach zdrowego rozsądku) byłby to opis, zawsze znaleźlibyśmy wiele obrazów należących do Z01, które w równej mierze pasowałyby do tego opisu. Osiągnięcie jednoznaczności za pośrednictwem predykatów malarskich jest w praktyce niewykonalne.

Po trzecie, ludzcy użytkownicy predykatów malarskich mają pewną, dość oczywistą i ważną w praktyce, przewagę nad ludzkimi użytkownikami predykatów fizykalnych. Otóż, aby orzec predykat malarski, wystarczy rzut oka na opisywany obraz; natomiast, aby orzec pewien predykat fizykalny, niezbędne są mozolne kalkulacje, niekiedy bardzo trudne do wykonania bez odpowiedniego sprzętu.

\title{
1.2. Naturalizacja malarstwa
}

Wpierw wprowadzimy kilka nowych określeń. Określenia te będą nieco sztuczne. Przez malarstwo ludowe rozumieć będziemy teorię dotyczącą obrazów, uprawianą wyłącznie za pomocą predykatów malarskich. Słowo „teoria” w interesującym nas kontekście może nieco dziwić. Aby mieć do czynienia z teorią, nie wystarcza sam opis, konieczne są jakieś ogólne prawa. Sądzę, że takich praw jest wiele, jeżeli tylko słowa „prawo” nie będziemy rozumieć zbyt restrykcyjnie. Mamy w końcu do czynienia z teorią ludową. Oto kilka takich praw:

Każdy obraz, który przedstawia atak husarii, przedstawia zazwyczaj jakieś konie

Każdy obraz, który przedstawia scenę polowania, przedstawia zazwyczaj jakieś zwierzęta

Tego rodzaju „praw” lub mądrości ludowego malarstwa jest bardzo wiele. W języku malarstwa ludowego możemy sformułować również ważne spostrzeżenia czy też „odkrycia”, dotyczące uniwersum obrazów. Oto kilka przykładów wyjaśniających, co mam na myśli:

\section{Obraz X jest miniaturą obrazu $Y$}

Obraz X i obraz Y przedstawiają tę samą bitwę widzianą z dwóch różnych punktów widzenia

\author{
Obrazy X, Y i Z przedstawiają różne fazy jednego i tego samego wyda- \\ rzenia
}


Przejdźmy teraz do głównego punktu tego rozdziału, czyli do naturalizacji malarstwa ludowego. Przez naturalizację malarstwa ludowego można rozumieć bardzo różne rzeczy. Cofnijmy się na chwilę i przypomnijmy sobie predykaty fizykalne. Przez malarstwo fizykalne (nazywać je będziemy również matrycowym) rozumieć będziemy malarstwo uprawiane wyłącznie za pomocą predykatów matrycowych. Malarstwo matrycowe jest malarstwem prawdziwie naukowym. Każdy termin jest zdefiniowany w sposób całkowicie jednoznaczny, a zakresy wszystkich predykatów są ostre. Co więcej, każde indywiduum należące do rozważanego uniwersum posiada jednoznaczną i pełną charakterystykę matrycową. W malarstwie matrycowym realizuje się w pełni ideał fizykalizmu. Wiadomo, ile obiektów istnieje i każdy obiekt jest w pełni i całkowicie jednoznacznie opisany. Malarstwo matrycowe zajmuje się też wszystkim, co istnieje. Gdyby pewien malarz chciał stworzyć nasz mini-świat, to miałby gotowy wzór. Wprowadźmy jeszcze na koniec pojęcie wzorowane na pojęciu superweniencji. Ponieważ naszym pojęciem będziemy się posługiwać tylko w odniesieniu do naszego mini-świata, to nazwiemy je superweniencją malarską. Przez superweniencję malarską rozumieć będziemy po prostu tę oto okoliczność, że dowolne dwa obiekty (czyli dowolne dwa obrazy), mające taką samą matrycę, muszą być takie same pod względem malarskim. Innymi słowy, dwa dowolne obrazy różniące się czymś pod względem malarskim muszą różnić czymś pod względem matrycowym. Superweniencja malarska jest, jak sądzę, oczywistym faktem i nie wymaga żadnych komentarzy.

Skupmy się wreszcie na naturalizacji. Pokusa zredukowania w pewien sposób malarstwa ludowego do malarstwa matrycowego jest nadzwyczaj silna. W końcu to ostatnie zajmuje się wszystkim, co istnieje i to w sposób w pełni ścisły. Możliwe są tutaj różne koncepcje. Ponieważ chcemy akcentować podobieństwa pomiędzy naszym przykładem a stanowiskami w filozofii umysłu, będziemy się terminologicznie zapożyczać.

\subsubsection{Gatunkowa (typiczna) teoria identyczności}

Wedle tej koncepcji, Własności malarskie (czyli te denotowane przez predykaty malarstwa ludowego) są identyczne $z$ własnościami matrycowymi (czyli denotowanymi przez predykaty malarstwa matrycowego) i można je do nich zredukować.

Za podejściem tym kryje się następujące myślenie. Po pierwsze, malarstwo matrycowe zajmuje się wszystkim, co istnieje. Nie istnieje nic ponad płótna zapełnione odpowiednimi barwami. Po drugie, jeżeli weźmiemy jakąś własność, o której rozprawiają teoretycy malarstwa ludowego, np. własność przedstawiania bitwy, to własność ta musi tkwić w obrazie. Innymi słowy, musi istnieć coś takiego, co jest wspólne wszystkim obrazom przedstawiającym bitwę i tylko im. Ponieważ jednak malarstwo matrycowe zajmuje się wszystkim, co istnieje, własność ta musi być pewną własnością matrycową. 


\subsubsection{Egzemplaryczna teoria identyczności}

Wedle tej koncepcji, Własności malarskich nie da się zredukować do własności matrycowych, ale każdy egzemplarz pewnej własności malarskiej jest identyczny z realizacją pewnej matrycy.

Wyobraźmy sobie, że pewnemu człowiekowi (oznaczmy go literą C) demonstrujemy różne obrazy. Niektóre przedstawiają bitwy, inne - sceny miłosne. C ma ponadto przed sobą pulpit, na którym są dwa przyciski, jeden czerwony, a drugi zielony. Naciśnięcie przycisku czerwonego (via inne artefakty) powoduje uruchomienie czysto mechanicznego urządzenia $U 1$, które działa przez dwie sekundy (po czym samo się wyłącza), a naciśnięcie przycisku zielonego powoduje uruchomienie innego czysto mechanicznego urządzenia U2, które też działa przez dwie sekundy (po czym samo się wyłącza). Załóżmy ponadto, że to, które urządzenie działa jest dla nas ważne. Urządzenia U1 i U2 powodują istotne (choć całkowicie różne) zmiany w środowisku. Zadaniem $C$ jest nacisnąć przycisk czerwony, gdy demonstrowany obraz przedstawia bitwę, a zielony, gdy scenę miłosną. W opisanej właśnie sytuacji własności malarstwa ludowego zaczynają odgrywać ważną rolę w ciągu przyczynowo-skutkowym, prowadzącym do uruchomienia odpowiedniego urządzenia. Uruchomienie urządzenia U1 jest spowodowane przez egzemplarz własności obraz przedstawiający scenę bitewną, a uruchomienie urządzenia U2 - przez egzemplarz własności obraz przedstawiający scenę miłosną. Każdy taki egzemplarz nie jest niczym innym, jak tylko realizacją pewnej matrycy (a więc niczym więcej niż rozkładem barwnych plam uzyskanych w opisany wcześniej sposób). Nie oznacza to wszakże, iż własności malarskie dają się zredukować do własności matrycowych. Jest to iluzja. Predykaty malarskie w żaden sposób nie zazębiają się z predykatami matrycowymi. Weźmy np. jeszcze raz predykat obraz przedstawiający bitwę. Jedyna definicja, którą jesteśmy sobie w stanie wyobrazić musiałaby wyglądać mniej więcej tak:

\section{X jest obrazem przedstawiającym bitwę wtedy i tylko wtedy, gdy matry- ca X-a jest taka lub taka lub taka...}

Mówiąc innymi słowy, definiens takiej definicji musiałby być bardzo długą alternatywą, której człony byłyby pełnymi matrycowymi opisami wchodzących w grę obrazów.

Załóżmy na moment, że w wyniku intensywnych prac ktoś (jakiś matematyk) zdołałby uprościć ten definiens, sprowadzając go do jakiejś w miarę „strawnej” formuły. będącej kombinacją predykatów matrycowych. Nawet wtedy nie można byłoby mówić o udanej redukcji. Zauważmy, że do tej pory rozważaliśmy tylko obrazy w kształcie kwadratu o boku 1m. Gdybyśmy znieśli to ograniczenie, to formuła ta załamałaby się natychmiast, podczas gdy predykat obraz przedstawiający bitwę mógłby być $w$ dalszym ciągu z powodzeniem używany.

Wnioski płynące z tych rozważań brzmią: (1) własności malarstwa ludowego nie odpowiadają żadnym własnościom malarstwa matrycowego i (2) każdy egzemplarz własności malarskiej jest identyczny z realizacją pewnej matrycy. 
Aby móc krótko charakteryzować opisaną wyżej sytuację, wprowadzimy dwa nowe pojęcia, a mianowicie od tej pory będziemy mówili o dwóch redukcjach pojęciowej i ontologicznej. W opisanym przypadku redukcja pojęciowa jest niemożliwa, ale redukcja ontologiczna jest oczywistością.

Przez redukcję ontologiczną malarstwa ludowego do malarstwa matrycowego rozumiemy po prostu fakt, że każdy obiekt z rozważanego uniwersum nie jest niczym innym (ani niczym więcej, ani niczym mniej), jak po prostu realizacją pewnej matrycy. Aby stworzyć całe nasze mini-uniwersum, wystarczy stworzyć realizację wszystkich matryc. Dokonując tego, stwarzamy zarazem wszystkie własności malarsko-ludowe.

\subsubsection{Dualizm własnościowy}

Własności malarstwa ludowego muszą być czymś innym niż własności malarstwa matrycowego. Stanowisko to jest wynikiem następującego rozumowania. Malarstwo ludowe powstało dużo wcześniej niż malarstwo matrycowe. Aby móc w ogóle porównywać malarstwo ludowe z matrycowym, aby móc stwierdzić ewentualną identyczność własności malarstwa ludowego z własnościami malarstwa matrycowego, muszą istnieć dwa człony tej identyczności, inaczej nie mogłoby w ogóle dojść do takiego odkrycia. Muszą więc co najmniej istnieć dwa różne punkty widzenia, niejako dwa różne aspekty, pod którymi możemy spoglądać na poszczególne obrazy - malarski i ludowy. Stanowisko to może mieć dwie odmiany, słabą i mocną. Wedle słabej, każdy obraz przedstawiający np. bitwę nie jest niczym innym niż realizacją pewnej matrycy. Niczym więcej i niczym mniej. W tej wersji dualizm własnościowy nie jest sprzeczny z egzemplaryczną teorią identyczności i, można się upierać, że nie nie ma żadnych ontologicznych konsekwencji. Można się jednak także upierać, że ma takie konsekwencje. To, ile własności posiadają obrazy, nie jest bez znaczenia. Wyjdźmy od sprawy oczywistej i weźmy jeszcze raz pod uwagę własność obraz przedstawiający bitwę. Własność ta może być zastąpiona tylko alternatywą własności matrycowych. Nasuwa się jednak pytanie, czy własność alternatywna jest w ogóle własnością? Można w to wątpić.

\subsubsection{Eliminacjonizm}

Stanowisko to jest najprostsze i daje się przedstawić mniej więcej tak. Malarstwo ludowe to $w$ istocie pewna teoria, służąca do opisywania obrazów. Teoria ta, tak jak każda inna, zaciąga pewne zobowiązanie ontologiczne, tzn. postuluje istnienie pewnych bytów - w naszym przypadku są to obrazy przedstawiające bitwę, obrazy przedstawiające sceny pogoni itd., itd. Czy byty te istnieją rzeczywiście? Jedynym sensownym kryterium istnienia jest jakość teorii. Nie ulega wątpliwości, że malarstwo matrycowe jest o wiele doskonalszą teorią i, co za tym idzie, wywiązuje się o wiele lepiej ze zobowiązania ontologicznego niż malarstwo ludowe. Nie ulega wątpliwości, że malarstwo matrycowe z czasem wyeliminuje malarstwo ludowe. Wraz z upadkiem malarstwa ludowego, w przeszłość odejdzie też jego 
ontologia. Za czas jakiś nikt już nie będzie mówił o obrazach przedstawiających bitwy czy uczty. W ten sposób doszliśmy do wniosku, że nie istnieją obrazy przedstawiające bitwy, ani obrazy przedstawiające sceny pogoni, ani..., ani... itd., itd.

Wykorzystywanie obrazów w charakterze pomocy naukowych na zajęciach z filozofii umysłu ma jednak swoje oczywiste ograniczenia. Obrazy w żaden sposób nie ułatwią nam prezentacji dwóch ważnych stanowisk, a mianowicie behawioryzmu i funkcjonalizmu. Behawioryzmu dlatego, że obrazy w ogóle się nie zachowują - wiszą na ścianach i nic nie robią; funkcjonalizmu dlatego, że obrazy są tak bardzo niepodobne do maszyn, jak to jest tylko możliwe.

Był taki czas (nie jesteśmy historykami i nie potrafimy podać dokładnego przedziału czasowego, ale na pewno należały doń lata 40., 50. i w znacznej mierze 60. XX w.), gdy behawioryzm był dominującą koncepcją umysłu. Koncepcją dominującą, zauważmy to, nie wśród laików, ale wśród filozofów analitycznych, zawodowo zajmujących się umysłem. Sądzono, że o ile tylko nie kierujemy się przesądami lub uprzedzeniami, to wówczas skazani jesteśmy niejako na opowiedzenie się za jakąś wersją behawioryzmu. Filozof analityczny, posiadający odpowiednie kompetencje logiczne, analizujący znaczenia terminów i poszukujący kryteriów ich użycia, powinien (wręcz musiał) być behawiorystą.

Czasy się zmieniają, zmieniają się też filozoficzne trendy. Behawioryzm nie jest już modny. Został zastąpiony w tej roli przez funkcjonalizm, który od pewnego czasu stanowi dominującą koncepcję umysłu. Nietrudno to zrozumieć. Rozwój technologiczny przełomu XX i XXI w. sprawił, że maszyny stały się nieodłączną częścią naszego życia. Stały się tak wszechobecne, że przestajemy je zauważać i tak niezastąpione, że nie wyobrażamy sobie bez nich życia. Maszyny, to, rzec można, środowisko naturalne współczesnych ludzi. Kim jest człowiek, jaka jest jego natura? A kimże mógłby być, jeśli nie maszyną - odpowiada z pełnym przekonaniem znaczna większość współczesnych analitycznych filozofów umysłu.

Przedstawimy obie te koncepcje. Wpierw behawioryzm, a następnie funkcjonalizm.

\section{Behawioryzm}

Zwykło się odróżniać dwa rodzaje behawioryzmu, a mianowicie tzw. behawioryzm metodologiczny, zwany również behawioryzmem psychologicznym oraz tzw. behawioryzm analityczny, zwany również behawioryzmem logicznym, a niekiedy filozoficznym. Pierwszy rodzaj wymyślony został przez psychologów (Watson, Skiner); drugi - przez filozofów (Wittgenstein, Ryle). Głównym przedmiotem zainteresowania behawiorystów metodologicznych były zwierzęta (psy, szczury, gołębie itd.) oraz bodźce i reakcje, natomiast behawioryści analityczni bardziej niż zwierzętami czy nawet ludźmi zainteresowani byli językiem zdroworozsądkowej psychologii. Ci pierwsi postulowali ograniczenie nauki o duszy do bodźców i reakcji; ci drudzy starali się wykazać, że pojęcia psychologiczne można zdefi- 
niować (nie uroniwszy nic z ich znaczenia) za pomocą słownictwa odwołującego się wyłącznie do zachowań i dyspozycji zachowaniowych. W dalszym ciągu skoncentrujemy się na behawioryzmie filozoficznym. Co się tyczy behawioryzmu psychologów, ograniczymy się do krótkiej wzmianki. Otóż główna idea behawioryzmu metodologicznego jest taka, że psycholodzy, badający żywe organizmy (ludzi nie wyłączając), miast spekulować na temat stanów duszy, powinni ograniczyć swoje zainteresowania do bodźców docierających do owych organizmów i reakcji tych organizmów na owe bodźce. Jeżeli psychologia (uprawiający ją psycholodzy) zastosują się do tej prostej zasady metodologicznej, to dyscyplina ta stanie się wreszcie prawdziwą nauką, a jej twierdzenia będą empirycznie sprawdzalne. W końcu bodźce i reakcje to są te rzeczy, które można (intersubiektywnie) obserwować, mierzyć i badać.

\subsection{Behawioryzm analityczny}

Pominiemy daty, nazwiska i klasyfikacje, które łatwo można znaleźć gdzie indziej, a skoncentrujemy się na samej istocie behawioryzmu analitycznego. Postaramy się zaprezentować raczej sam sposób myślenia charakterystyczny dla behawioryzmu filozofów niż odtwarzać z aptekarską pieczołowitością czyjeś poglądy. Dzięki takiemu podejściu będziemy wyraziści i sugestywni, ale może się zdarzyć, że niekiedy wypaczymy nieco (pomijając różne „ale”) rzeczywiste intencje historycznych postaci - ojców założycieli i propagatorów behawioryzmu analitycznego.

Behawioryzm analityczny powstał i był w modzie w tym samym (mniej więcej) czasie, gdy filozofowie analityczni (a w każdym razie ci najbardziej wpływowi) sądzili, że najważniejsze problemy filozoficzne są w gruncie rzeczy natury językowej i można je rozwiązać, uważnie analizując język. Dotyczyć by to miało również problemów tradycyjnie zaliczanych do filozofii umysłu, w tym słynnego pytania o stosunek zachodzący pomiędzy umysłem a ciałem. Problem ten, czy raczej pseudo-problem, generowany jest przez błędną interpretację języka codziennej psychologii. Nim wyjaśnimy, na czym ta błędność miałaby polegać i jaka interpretacja miałaby być poprawna, zauważmy, że wedle filozofów myślących w kategoriach filozoficznego behawioryzmu (co się tyczy języka), to sprawy mają się tak, że:

Wyrażenia języka (w szczególności predykaty jedno- lub wieloargumentowe) muszą mieć określone warunki (kryteria, reguły, dyrektywy itd.) użycia. Znaczenia terminów to nic innego, jak właśnie warunki (kryteria, reguły, dyrektywy itd.) ich użycia. Warunki te powinny być takie, że użytkownicy języka są w stanie (w zasadzie) sprawdzić, czy są one spełnione (a więc czy może ono zostać użyte). W przeciwnym razie wyrażenie (wyrażenia) jest bezsensowne (nie posiada żadnego znaczenia). W przypadku zdań oznaczałoby to, że muszą one posiadać warunki prawdziwości, które są tym samym 
co znaczenie zdania, a użytkownicy języka są w stanie (w zasadzie) sprawdzić, czy są one spełnione. Zdanie, którego wartości logicznej nie można (nawet w zasadzie) ustalić, byłoby bezsensowne.

Powyższa zasada, jak sądzono, jest (a w każdym razie powinna być) uniwersalna. Język, którym się posługujemy opisując cechy charakteru lub stany umysłu, innych ludzi bądź własne, nie może tu stanowić żadnego wyjątku i musi być wyposażony w odpowiednie kryteria. W przeciwnym razie wypowiedzi wyrażone $w$ tym języku byłyby bezsensowne, a przecież wszyscy wiemy, że takimi nie są. Wydaje się rzeczą oczywistą, że za pomocą żargonu codziennej psychologii przekazujemy sensowne, a przy tym niekiedy bardzo ważne, informacje. Cóż jednak miałoby być przedmiotem owych informacji? Najszybciej wyjaśnimy, w czym rzecz i na czym polegała różnica pomiędzy tradycyjnym podejściem a behawioralną rewolucją w interpretowaniu języka psychologii, podając konkretny, choć zmyślony przykład. Załóżmy, że poniższy opis jest fragmentem listu, w którym pewna studentka opisuje pana X. Załóżmy ponadto, że adresatem listu jest kilkuosobowe grono przyjaciół owej studentki, a charakteryzowana osoba - wykładowcą na jednej z wyższych uczelni:

[...] X jest dość wysoki, a przy tym otyły, ma czarne włosy, niebieskie oczy, orli nos i głęboką bliznę na lewym policzku. $X$ ma dobrotliwy wyraz twarzy i ciepły uśmiech, ale - miejcie to na uwadze - jest to osobnik złośliwy, a przy tym, pamiętliwy i mściwy. Odnoszę wrażenie, że nie lubi on kobiet (podobno był kiedyś nieszczęśliwie zakochany) i studentów, chociaż szanuje osoby naprawdę wybitne. Zarazem jednak pan X ma dużo cywilnej odwagi i potrafi być hojny i wspaniałomyślny. Nie wiem, czy ma to jakieś znaczenie, i czy taka wiedza wam się do czegoś przyda, ale X to człowiek głęboko religijny, mocno wierzący w Bożą sprawiedliwość [...].

Nietrudno zauważyć, że pan $X$ jest opisywany we fragmencie powyższego listu na dwa różne sposoby, jakby za pomocą dwóch różnych języków, a mianowicie z użyciem wyrażeń, które w dalszym ciągu będziemy nazywali fizykalnymi (zaznaczyliśmy je kursywą) oraz wyrażeń, które w dalszym ciągu będziemy nazywali psychologicznymi (zaznaczyliśmy je kursywą i pogrubionym drukiem). Wyrażenia fizykalne opisują ciało pana X, cóż jednak opisują predykaty psychologiczne? I jakie są warunki (kryteria, reguły, dyrektywy itd.) ich użycia? Stara, tradycyjna, dobrze znana odpowiedź na to pytanie brzmi: Predykaty psychologiczne opisują duszę X-a. Opisując człowieka stosujemy dwojakiego rodzaju słownictwo dlatego, że człowiek (w przeciwieństwie do stołów, krzeseł, kamieni...) jest istotą składającą się z ciała i duszy. Za pomocą predykatów fizykalnych opisujemy ciało, a za pomocą psychologicznych - duszę. Ciało jest wysokie, otyłe, ma niebieskie oczy itd., ale to dusza jest złośliwa, mściwa, odważna itd. I to dusza, a nie ciało jest religijna i wierzy w Bożą sprawiedliwość; i to ona, a nie ciało, była kiedyś (jeśli to prawda) nieszczęśliwie zakochana. Dodajmy, że to dusza bywa zmartwiona, smutna, rozczarowana i wesoła i to ona, a nie ciało, doświadcza tzw. fizycznych 
przykrości (np. wtedy, gdy ktoś ukłuje ciało szpilką) i zmysłowych przyjemności (np. wtedy, gdy ciało spożywa smaczny obiad) itd., itd. Dualizm języka służącego charakteryzowaniu ludzi jest pochodną dwoistości ludzkiej natury.

Okoliczność, że za pomocą predykatów psychologicznych opisujemy duszę sprawia, że język psychologii różni się zasadniczo od języka fizykalnego, a zdania wyrażone w tym języku mają specyficzne warunki prawdziwości. Otóż dostęp poznawczy do duszy posiada tylko sama ta dusza i tylko ona naprawdę wie, kogo lubi, kocha, szanuje..., w co wierzy i o czym jest przekonana itd. Ludzie, nie mając bezpośredniego dostępu do dusz swoich bliźnich, mogą się tylko domyślać na podstawie zachowania (narzędzie to bywa jednak zawodne) lub na podstawie słownych relacji (bywa jednak, że ludzie kłamią), kogo oni naprawdę lubią i szanują, a kogo nienawidzą; o czym są przekonani i w co naprawdę wierzą itd. Aby uświadomić sobie rewolucyjność behawioryzmu, musimy zdać sobie sprawę z tego, że naszkicowane powyżej stanowisko było, nim powstał behawioryzm, stanowiskiem dominującym nie tylko wśród laików, posługujących się na co dzień psychologicznym żargonem, lecz także wśród zawodowych psychologów. W podręcznikach psychologii, napisanych w latach 20. i 30., a nawet 40 . XX wieku czytamy często we wstępach, że psychologia (jak sama nazwa wskazuje) jest nauką o duszy, a podstawowym narzędziem tej nauki jest introspekcja. Gilbert Ryle w swej słynnej książce Czym jest umysł, wydanej po raz pierwszy w roku 1948, nazywa kartezjanizm teorią oficjalną, a dogmat O duchu w maszynie - mitem, który cieszy się powszechnym uznaniem. Behawioryzm analityczny był we współczesnej filozofii umysłu pierwszą (w porządku chronologicznym) skrajnie materialistyczną doktryną, pierwszą próbą „przegonienia ducha” z „cielesnej maszynerii”. Przy czym, zaznaczmy to jeszcze raz, sądzono, że jeżeli z "duchem w maszynie” są jakieś problemy, to są one natury językowej. Aby wygonić ducha z maszyny, wystarczy - sądzono - przepłoszyć go z języka. Spróbujmy spojrzeć na język psychologii oczami filozofów behawiorystów i odtworzyć w ogólnym zarysie ich koncepcję.

\subsection{Behawioryzm analityczny (ciąg dalszy)}

Rozpocznijmy od tego, że za pomocą terminów psychologicznych nie opisujemy duszy. Myślenie takie to pochodna kartezjańskiego mitu (pomysłodawcą tego określenia jest G. Ryle). Błędna interpretacja znaczeń tych terminów jest zresztą jednym z głównych źródeł przekonań dualistycznych. Aby odczarować język psychologii, należy przyjrzeć się, w jaki sposób się nim posługujemy, zbadać reguły użycia terminów psychologicznych, przeprowadzić ich staranną logiczną analizę. Analiza taka uzmysłowi nam, jakie jest rzeczywiste znaczenie tych terminów, pokaże, że do opisu zachowań i dyspozycji zachowaniowych można je zdefiniować, nie tracąc nic $z$ ich znaczenia za pomocą słownictwa odwołującego się wyłącznie do zachowań i dyspozycji zachowaniowych. Reguły te (czy też kryteria ich użycia) muszą zresztą odwoływać się do ludzkich zachowań. Nie ma żadnej innej możliwości i nie trzeba wiele, aby sobie to uświadomić. 
Weźmy pod uwagę jakiś termin psychologiczny, np. złośliwy i załóżmy, tytułem przykładu, że wśród studentów pewnego wydziału pewnego uniwersytetu panuje opinia, że pewien wykładowca - oznaczmy go przez $X$ - jest wyjątkowo złośliwy. Otóż opinia ta albo jest zgodna $\mathrm{z}$ faktycznym stanem rzeczy i pan $\mathrm{X}$ istotnie jest złośliwy, albo mamy do czynienia z plotką, nie mającą nic wspólnego z rzeczywistością. Jak można to sprawdzić? Wszak musi istnieć jakiś sposób. Gdyby nie było żadnego, to musielibyśmy przyjąć, że termin ten aplikowany jest na chybił trafił lub wedle upodobania. Tak jednak nie jest. Bywa, że ludzie naprawdę są złośliwi i zdarza się, że błędnie przypisuje się im tę własność. Informacja o tym, że ktoś, od kogo zależą w jakiejś mierze nasze losy, jest złośliwy, o ile prawdziwa, może oszczędzić nam wielu kłopotów i pomóc w uniknięciu niebezpieczeństw. Predykatów psychologicznych nie przydziela się tak, jak się rozdaje gwiazdkowe prezenty. Muszą istnieć warunki ich użycia i muszą to być takie warunki, że użytkownicy języka są w stanie, w zasadzie, sprawdzić, czy są one spełnione. Cóż to jednak mogą być za warunki?

Weźmy wpierw pod uwagę tradycyjne, kartezjańsko-dualistyczne podejście i załóżmy, że terminy psychologiczne opisują duszę. Gdyby tak było, to - wskazywano - termin „złośliwy” miałby dwa całkowicie różne znaczenia: jedno wtedy, gdy terminem tym posługiwaliby się studenci w odniesieniu do pana $X$, drugie wówczas, gdy pan $\mathrm{X}$ opisywałby siebie. W pierwszym przypadku podstawą do orzeczenia tego terminu byłoby zachowanie (nie ma żadnej innej możliwości), w drugim pan $\mathrm{X}$, aby orzec ten termin o sobie, musiałby odwołać się do introspekcji i na tej podstawie ustalić, czy użycie terminu „złośliwy” jest zasadne. W tym drugim przypadku pan $\mathrm{X}$ musiałby za pomocą samoobserwacji umieć sprawdzić, czy jego dusza zasługuje na miano złośliwej. Pomysł ten przy bliższym zastanowieniu sprawia jednak wrażenie nonsensu. Po prostu nikt nie wie, w jaki sposób, posługując się introspekcją, można byłoby sprawdzić (po czym poznać?) lub rozpoznać, czy dusza zasługuje na miano złośliwej, hojnej, odważnej, mściwej. Po prostu nikt nie wie, jak miała by wyglądać dusza złośliwa, odważna, hojna... O takich rzeczach nie można się dowiedzieć na podstawie introspekcji. Terminy te nazywają dyspozycje zachowaniowe a ich definicje, jeśli ktoś próbowałby je podawać, musiałaby wyglądać jakoś tak:

X jest mściwy wtedy i tylko wtedy, gdy w takich to a takich sytuacjach zachowywałby się tak a tak

X jest odważny wtedy i tylko wtedy, gdy w takich to a takich sytuacjach zachowywałby się tak a tak

$\mathrm{X}$ jest chciwy wtedy i tylko wtedy, gdy w takich to a takich sytuacjach zachowywałby się tak a tak

X jest złośliwy wtedy i tylko wtedy, gdy w takich to a takich sytuacjach zachowywałby się tak a tak, itd., itd. 
Sytuacji, o które tutaj chodzi jest zbyt wiele, a opisy zachowań musiałaby być zbyt skomplikowane, aby można było podać konkretne definicje i wyliczyć wszystkie sytuacje, które mamy na uwadze i wszystkie zachowania, które miałyby im towarzyszyć. Nie ulega jednak wątpliwości, że aplikując słownictwo psychologiczne, czy to do innych ludzi, czy do siebie, odwołujemy się do odpowiednich zachowań w odpowiednich sytuacjach.

Ktoś mógłby jednak zaprotestować. Analizując pojęcia psychologiczne, zbytnio ułatwialiśmy sobie zadanie. Terminy, takie jak: złośliwy, odważny, hojny, mściwy itd. opisują, mówiąc potocznie, tzw. cechy charakteru. Argumentacja behawiorystów, że nazywają one dyspozycje zachowaniowe brzmi dość przekonująco. Terminy te stanowią jednak tylko fragment terminologii psychologicznej. Oprócz nich istnieje przecież wiele terminów, które, wydaje się, opisują nie tyle trwałe dyspozycje, ile zachodzące, właśnie „tu i teraz”, wewnętrzne przeżycia. Przeżyciom tym często nie towarzyszy żadne zachowanie, natomiast zdarza się, że ludzie będący ich podmiotami opisują je. Aby lepiej wyjaśnić, o co chodzi, przeanalizujemy kilka przykładów.

\subsection{Przykłady i propozycje}

Przykład 1. Nauczycielka odpytuje uczniów, wpierw ucznia bardzo dobrego, który odpowiada bardzo słabo, nie przygotował się. Nauczycielka mówi: jestem zdumiona i rozczarowana. Następnie odpytuje ucznia bardzo słabego, który odpowiada bardzo dobrze. Nauczycielka mówi: jestem zdziwiona i zadowolona. Wreszcie próbuje odpytać ucznia, który sprawia kłopoty wychowawcze. Uczeń ten „w odpowiedzi” stroi miny. Nauczycielka mówi: jestem zszokowana i jest mi bardzo przykro itd., itd. Oto prosty przykład użycia terminów, które, jak się wydaje, opisują stan aktualnych przeżyć nauczycielki. Terminy te nie odnoszą się do dyspozycji. Nauczycielka nie jest rozczarowująca się, dziwiąca, zdumiewająca itd. Pani z naszego przykładu być może w ogóle bardzo rzadko się dziwi, rozczarowuje itd. Być może przeżycia rozczarowania i zdumienia były jedynymi w jej całym dotychczasowym życiu. To właśnie tu i teraz nauczycielka jest zdumiona, rozczarowana, zdziwiona itd., tu i teraz daje słowny wyraz swojemu życiu wewnętrznemu. Cóż innego, tym razem, jeśli nie odpowiednie przeżycia, rozpoznane za pomocą introspekcji, mogłyby skłonić do posłużenia się odpowiednim słownictwem? Naszym zdaniem, najbardziej zgodna z duchem behawioryzmu byłaby odpowiedź pochodząca od Wittgensteina, a mianowicie, że: Tak zwany proces wewnętrzny musi mieć kryteria zewnętrzne.

Olbrzymią rolę w ukształtowaniu się behawiorystycznego sposobu myślenia miała zapoczątkowana przez Wittgensteina dyskusja dotycząca możliwości istnienia tzw. prywatnego języka przeżyć. Według tego filozofa, wyrażenia tego języka, pozbawione „zewnętrznej” kontroli w oparciu o publicznie dostępne kryteria i używane tylko na podstawie „widzi mi się" praktykującego introspekcję, byłyby w gruncie rzeczy pozbawione jakiejkolwiek kontroli i używane na chybił trafił. Nie 
oznacza to, że nie posiadamy żadnego „życia wewnętrznego”, żadnych doznań. Raczej jest tak, że fenomeny składające się na tzw. życie wewnętrzne są na tyle nieokreślone, zmienne i niepowtarzalne, że nie mogłyby się stać podstawą funkcjonowania jakiegokolwiek języka.

Czy jednak Wittgenstein miał rację? Długo by o tym dyskutować. Jednym z najsilniejszych argumentów przemawiających za „zewnętrznością” kryteriów użycia terminów psychologicznych, również tych, które miałyby się odnosić do przeżyć, jest ta oto okoliczność, że języka, w tym również tej jego części, którą nazywaliśmy językiem psychologii, uczymy się (wszyscy, bez wyjątku) od innych ludzi. Jak to się odbywa? Spróbujmy jeszcze raz kartezjańskiej strategii i wyobraźmy sobie, jak mogłaby wyglądać nauka języka przeżyć w oparciu o kryteria wewnętrzne (przeżyciowe). Dla ustalenia uwagi załóżmy, że próbujemy nauczyć języka przeżyć kilkuletniego Jasia, który posługuje się już wcale sprawnie językiem polskim, natomiast zupełnie jeszcze nie włada tzw. językiem przeżyć (np. dlatego, że został poddany takiemu eksperymentowi przez psychologów behawiorystów). Jak tak nauka mogłaby wyglądać? Oto dwie propozycje.

Propozy cja 1. Tata woła Jasia i mówi: „Synu, musisz nauczyć się wyrażać swoje wewnętrzne przeżycia. Inne dzieci już to potrafią. Nauka będzie wyglądała w ten sposób, że tatuś będzie kolejno (na użytek tej nauki) zdumiony, rozczarowany, zadowolony i pogrążony w głębokim smutku. Ty zasię obserwuj uważnie duszę tatusia. Gdy twoja (dusza) znajdzie się w podobnym stanie, będziesz wiedział, co powiedzieć".

Oczywiście propozycja jest absurdalna, również dla kartezjańskiego zwolennika wewnętrznych kryteriów z tego względu, że Jaś nie ma i mieć nie może dostępu do duszy tatusia. W jaki zatem sposób można by nauczyć się języka przeżyć od ludzi, którzy już go znają? Ponieważ Jaś nie ma dostępu do dusz ludzi znających język przeżyć, ale ma dostęp do własnej, to jedyny sposób, który nam się nasuwa byłby następujący.

Propozy cja 2. Tata woła Jasia i mówi: „Synu, musisz nauczyć się wyrażać swoje wewnętrzne przeżycia. Inne dzieci już to potrafią. Nauka będzie wyglądała w ten sposób, że tatuś podłączy cię za chwilę do specjalnej machiny do wywoływania przeżyć. Będziesz kolejno (na użytek tej nauki) zdumiony, rozczarowany, zadowolony i pogrążony w głębokim smutku. Właśnie tak nazywają się te przeżycia, które machina będzie w tobie wywoływać w wymienionej kolejności. Uważnie obserwuj (za pomocą introspekcji) swą duszę. Gdy znajdzie się ona kiedyś w którymś spośród tych stanów (jutro, za tydzień lub za rok), będziesz wiedział, co powiedzieć i wyrazisz swoje przeżycia odpowiednimi słowami.

Propozycja ta tak dalece odbiega od rzeczywistej praktyki językowej, że sprawia wrażenie żartu. Rzeczywista nauka języka psychologii z konieczności wygląda zupełnie inaczej.

Wyobraźmy sobie, że pewna pani uczy się dopiero języka psychologii. W pewnym momencie zauważamy - my, jej nauczyciele - że nadużywa ona słowa rozczarowana. Kolega z pracy oddał jej pożyczone od niej pieniądze w umówionym terminie, a ona mówi, że jest rozczarowana. Pociąg wjeżdża na stację dokładnie o przewidzianej porze, a ona znowu mówi, że jest rozczarowana. 
Obiad jest smaczny i ona to przyznaje, ale i tak jest rozczarowana. Dlaczego ona ciągle taka rozczarowana? Gdyby kryteria użycia słowa rozczarowana były „wewnętrzne”, pomyślelibyśmy sobie: „No cóż, taka to jest dziwna dusza. Przydarza się jej przeżycie rozczarowania znacznie częściej niż innym ludziom i w niestandardowych sytuacjach. Być może przydałaby się jej pomoc psychologa". Ale nie, my zaczynamy ją poprawiać. Mówimy: „Słuchaj, nadużywasz tego słowa. Mówisz jestem rozczarowana w sytuacjach, w których nie używa się tego terminu".

Termin rozczarowana ma „zewnętrzne” i publicznie dostępne warunki użycia. Jakże moglibyśmy ją poprawiać (nie mając wglądu do jej duszy) i jakże ona mogłaby się od nas nauczyć używania tego słowa, gdyby było inaczej?

Powróćmy do przykładu z nauczycielką. Czy używając odpowiednio terminów: zdumiona rozczarowana, zadowolona i zszokowana opisywała ulotne stany swej duszy, czy też raczej używała tych terminów dlatego, że używa się ich w takich właśnie zewnętrznych i publicznie dostępnych sytuacjach? Filozofowie-behawioryści nie mieliby wątpliwości, że druga odpowiedź jest prawdziwa. Używamy tych oraz wielu innych terminów psychologicznych w określonych sytuacjach zewnętrznych, zupełnie nie interesując się przy tym stanem duszy. Nie znaczy to, że nie posiadamy żadnych subiektywnych doznań. Owszem, doświadczamy ich. Nie one jednak - zdaniem behawiorystów - dostarczają kryteriów, w oparciu o które funkcjonuje język psychologii. Jedno i to samo bliżej nieokreślone wiercenie w brzuchu w gabinecie dentystycznym opiszemy jako strach przed lekarzem, a w filozoficznej kawiarni, być może, jako niepokój metafizyczny.

Ostatnia uwaga, dotycząca tzw. języka przeżyć. Wielu ludzi boleje nad tym, że język psychologii jest zbyt ubogi, aby wyrazić całe bogactwo ich duchowego życia. Wydaje się, że w takiej sytuacji powinny powstawać prywatne języki. O ile nam wiadomo, nie powstają. Dlaczego? Wittgenstein ma na to odpowiedź. Tak zwany proces wewnętrzny musi mieć zewnętrzne kryteria.

\section{Funkcjonalizm}

Istnieje kilka różnych odmian funkcjonalizmu. My nie będziemy jednak tutaj rozdzielać włosa na czworo i mnożyć podziałów. Niewiele byśmy dzięki temu zyskali. Ograniczymy się do przedstawienia głównej idei, z tym, że przedstawimy ją z dwóch różnych punktów widzenia. We współczesnej filozofii umysłu, gdy mowa o maszynach, ma się na myśli najczęściej komputery i wówczas często wprowadza się rozróżnienie na sprzęt i oprogramowanie (w polskojęzycznej literaturze przedmiotu używa się niekiedy angielskich odpowiedników tych terminów, a mianowicie odpowiednio hardware i software). Otóż przedstawimy funkcjonalistyczną ideę maszynowości człowieka z dwóch różnych punktów widzenia, a mianowicie od strony „sprzętu”, czyli w tym przypadku ludzkiego ciała, a następnie „oprogramowania”, czyli w tym przypadku całej sfery stanów mentalnych czy też szeroko rozumianej psychologii. W tym drugim przypadku słowo system byłoby bardziej stosowne niż określenie „maszyna”. 


\subsection{Funkcjonalizm po raz pierwszy}

Człowiek, czyli jego ciało (bo, jak wiadomo, duszy nie ma), jest maszyną i, co za tym idzie, składa się, podobnie jak inne maszyny (rower, pralka automatyczna czy komputer) z mniejszych części oraz posiada (znowu podobnie, jak inne maszyny) wejście i wyjście. Wyjaśnijmy od razu, że w przypadku człowieka wejście to powierzchnia skóry, poprzez którą przedostają się bodźce do jej wnętrza z tzw. środowiska, a na wyjściu człowiek wytwarza zachowanie, gdyż każda maszyna coś robi (pralka automatyczna pierze, samochód jedzie, a człowiek - jakoś się zachowuje). Mniejsze części, z których składa się człowiek, pełnią (podobnie, jak w innych maszynach) określone funkcje (tzn. wpływają w całkiem określony sposób na funkcjonowanie innych części i w efekcie - na zachowanie całej maszyny). Wynika stąd, że człowieka można rozebrać (podobnie, jak inne maszyny) na mniejsze części (co akurat nie jest trudne) i ponownie złożyć (co jest łatwe w przypadku rowerów, pralek automatycznych i komputerów, ale nikomu jeszcze nie udała się taka sztuka w przypadku ludzi czy choćby biedronek; czym nie należy się przejmować, gdyż piszemy o tym, co w zasadzie wykonalne, a nie o tym, co tu i teraz potrafimy zrobić) i w efekcie otrzymamy tę samą (a przynajmniej taką samą) maszynę, a w każdym razie maszynę, która zachowuje się dokładnie tak samo, co w przypadku maszyn jest w końcu najważniejsze.

Z „maszynowości” człowieka wynika słynna zasada wielości realizacji. Otóż, jeżeli człowiek jest maszyną i składa się z mniejszych części pełniących określone funkcje, to cóż to szkodzi, jeśli jedną z tych mniejszych części (której funkcje wcześniej dokładnie poznaliśmy) wymontujemy i na jej miejsce wmontujemy nową, inną pod względem fizycznym (np. cięższą, lżejszą, o innym składzie chemicznym; co kto lubi) część, ale pełniącą dokładnie te same funkcje. Maszyna nie dozna przez to żadnego szwanku, a jej funkcjonowanie (jeśli stara część była zużyta lub uległa uszkodzeniu) może się nawet poprawić. Rzecz jasna, to, co można zrobić z jedną częścią, można zrobić z wieloma, a wreszcie ze wszystkimi (gdy mamy do czynienia z ludźmi lub choćby małpami, to należy to robić stopniowo i po kolei, żeby system się nie wystraszył). Otrzymamy w ten sposób tę samą (a przynajmniej taką samą) maszynę, choć inaczej fizycznie zrealizowaną; cięższą, Iżejszą; o innym składzie chemicznym itd., itd. O słuszności prezentowanego podejścia w przypadku takich maszyn, jak rowery, pralki automatyczne, samochody czy komputery nie trzeba nikogo przekonywać, gdyż nieomal każdy wymieniał w rzeczonych maszynach jakieś zużyte części na nowsze, często inne pod względem fizycznym, a funkcjonowanie maszyny tylko się dzięki temu poprawiało.

W przypadku maszyn zwanych tradycyjnie ludźmi wskazana jest ostrożność, ale - jeśli odrzucimy przesądy - to powinna to być ostrożność podyktowana tylko niedostatecznym (jeszcze) stanem wiedzy. Funkcje wielu narządów (czyli części) są skomplikowane, a ich pełne poznanie nie jest proste. Wszelako nawet w przypadku maszyn tak skomplikowanych jak ludzie trudno wątpić w trafność prezentowanych założeń. Odwołajmy się znowu do praktyki. Są już sztuczne ser- 
ca, sztuczne nerki, sztuczne woreczki żółciowe i żołądki, a utracone w wyniku wypadków ręce zastępuje się artefaktami, którymi pacjenci sprawnie się posługują i w których posiadają zmysł dotyku. Dodajmy, że uczeni specjaliści pracują intensywnie nad sztucznym słuchem i oczami, które byłyby wytwarzane (w niedalekiej przyszłości) fabrycznie. Robocop, istota z biologicznym mózgiem i wytworzonym fabrycznie ciałem (póki co, twór wyobraźni filmowców), leży już w zasięgu techniczno-inżynierskich możliwości naszej cywilizacji.

Jedną z tych części ludzkiego ciała, której nie próbowano do tej pory wymieniać jest mózg, zwany dawniej siedliskiem duszy. Nie ulega jednak wątpliwości, że na przeszkodzie (po odrzuceniu przesądów) stoi tylko brak odpowiedniej wiedzy i piętrzące się trudności techniczne. W końcu mózg też jest maszyną, też składa się z mniejszych części i też coś robi. Cóż zatem stoi na przeszkodzie, aby - przynajmniej w wyobraźni - zastosować ogólne zasady do zbyt skomplikowanych (na razie) w praktyce przypadków. Czynią to w literaturze przedmiotu filozofowie-funkcjonaliści, wymieniając w starannie zaplanowanych eksperymentach myślowych różne elementy mózgu (są to na ogół neurony) na różne inne obiekty; niekiedy są to artefakty (najczęściej chipy); niekiedy małe ludziki; niekiedy Chińczycy; a niekiedy nawet rury z płynącą w nich wodą lub wiatraki. W końcu nie jest ważne, czym są te obiekty, ważne jest to, aby pełniły te same funkcje, które pełniły neurony itd., itd. (w jaki sposób np. wiatrak, zdaniem pomysłodawcy, mógłby pełnić tę samą funkcję, co neuron to osobna sprawa, którą tutaj nie będziemy się zajmować). W każdym razie, jeżeli funkcjonalizm jest prawdziwy (a przecież jest! - myśli wielu analitycznych filozofów umysłu), to pełna realizacja człowieka w innym (niż biologiczne) tworzywie też jest (w zasadzie) możliwa. A jeśli tak, to puśćmy wodze fantazji i przenieśmy się na chwilę w (niedaleką, być może) przyszłość. Ludzie prędzej lub później porzucą „biologiczne skorupy” i, jeśli można się tak wyrazić, „przeprowadzą się”. Nowe, lepsze, trwalsze ciała... itd., itd.

Przerwijmy na chwilę narrację funkcjonalisty. Czy jest ona prawdziwa? Długo by o tym pisać. W każdym razie jest to narracja dominująca. Sądzę, że nie tylko filozofowie- funkcjonaliści myślą w ten sposób, ale i wielu (zwłaszcza tych młodych) laików. Funkcjonalizm jako pewien sposób myślenia o otaczającym nas świecie i naturze umysłu, mam wrażenie, staje się teorią zdrowego rozsądku współczesnych ludzi. W jakiejś mierze przyczyniła się do tego kultura popularna. W latach 80. ubiegłego stulecia nastąpił prawdziwy wysyp książek i filmów o tematyce cybernetycznej. Literatura cyberpunkowa i obrazy, takie jak Robocop, Terminator czy Blade Runner sprawiły, że postać cyborga stała się ikoną popkultury.

\subsection{Funkcjonalizm po raz drugi}

Tym razem nie interesuje nas ciało, ale byty, do których zwykliśmy się odwoływać, opisując cudze lub własne życie umysłowe. A bytów tych, będziemy je 
zwać ogólnie stanami psychicznymi lub mentalnymi, jest wcale dużo. Najczęściej wymienianymi stanami mentalnymi w interesującym nas kontekście są tzw. postawy propozycjonalne, wśród których za najważniejsze (bo mające największy wpływ na zachowanie) uważa się przekonania i dążenia oraz stany zwane w literaturze przedmiotu (od pewnego czasu; dawniej byty te zwano najczęściej wrażeniami lub jakościami zmysłowymi) qualiami, a więc stany, których się doświadcza, spoglądając np. na dojrzałego pomidora (a doświadcza się widzenia czegoś czerwonego) lub na świeżą zieloną trawę (doświadcza się widzenia zieleni), lub przeciągając ręką po szorstkiej lub gładkiej powierzchni, lub wkładając rękę do zimnej bądź gorącej wody itd., itd. Mówiąc krótko, chodzi o jakościową czy też fenomenalną stronę naszego świadomego życia, która towarzyszy nam nieustannie wówczas, gdy jesteśmy przytomni i „poruszamy się” w świecie, a która znika całkowicie tylko wówczas, gdy jesteśmy pogrążeni w głębokim śnie pozbawionym marzeń sennych. Tak więc, w skrócie i uproszczeniu, przedstawiałby się ludzki software. Przejdźmy do funkcjonalizmu.

Otóż główna idea funkcjonalizmu jest taka, że stany mentalne jakiegoś obiektu (żywego organizmu biologicznego pochodzenia, np. człowieka lub robota) są w pełni określone poprzez następujące trzy czynniki: (1) przyczyny, które je wywołują (a są one wywoływane poprzez bodźce docierające do środowiska lub inne stany mentalne); (2) wpływ, jaki wywierają (skutki, do których doprowadzają) na inne stany mentalne; (3) wpływ jaki wywierają (skutki, do których doprowadzają) na zachowanie organizmu. Innymi słowy, stany mentalne tworzą system, a elementy tego systemu są w pełni zdeterminowane poprzez odpowiednią sieć zależności przyczynowo-skutkowych. Wynika stąd, że określony system mentalny (np. system stanów psychicznych właściwy autorowi tego tekstu) można realizować w dowolnym pod względem fizycznym tworzywie, byleby tylko wzór przyczynowo-skutkowych oddziaływań został zachowany. Przy takim podejściu, wielość fizycznych sposobów, za pomocą których można byłoby zrealizować określony system mentalny przyprawia o zawrót głowy i jest jedną z głównych przyczyn sceptycyzmu niektórych autorów w stosunku do funkcjonalistycznej ideologii.

Szczególnie dziwny i trudny do przyjęcia wydaje się funkcjonalizm w przypadku qualiów. Weźmy np. pod uwagę ból i (w celu ustalenia uwagi) wyobraźmy sobie, że siedzimy w fotelu dentystycznym, a pan dentysta (z jakichś tam powodów bez znieczulenia) chwyta kleszczami bolący ząb i... Już po chwili, a właściwie nieomal w tym samym momencie czujemy straszliwy ból, ból, którego nie sposób opisać, ale którego nie pomylilibyśmy z niczym innym i... już po chwili, a właściwie nieomal w tym samym momencie słyszymy charakterystyczne i głośne: Ojej!... Otóż, według funkcjonalizmu, to straszliwe doznanie, którego doświadczyliśmy w fotelu jest w pełni, wyczerpująco i całkowicie scharakteryzowane poprzez przyczynę, która je wywołała (kleszcze dentysty) i skutek, który za sobą pociągnęła (głośne: Ojej!). Cała fenomenalno-jakościowo- wrażeniowa straszliwość bólu nie ma znaczenia, nie istnieje w funkcjonalistycznym opisie tego, jak się sprawy mają. Trudno uwierzyć, że w odniesieniu do qualiów funkcjonaliści mają rację. 
(Wyobraźmy sobie, że trzyletni Jasio ma mieć rwany ząb i że z jakichś ważnych powodów ma się to odbyć bez znieczulenia. Jaś, który nigdy wcześniej nie był u dentysty, wiedziony ciekawością, pyta: Mamo, co się czuje, jak pan dentysta wyrywa ząb? A mama, filozofka-funkcjonalistka, odpowiada: Czuje się coś, co jest powodowane przez wyrwanie zęba, a samo powoduje okrzyk: „Ojej!” Dziwne, prawda?!) 



\section{Część II PROBLEMY}





\section{Rozdział czwarty}

\section{PROBLEMY Z POJĘCIEM ZACHOWANIA}

Pojęcie zachowania jest jednym z tych nielicznych pojęć, które jest równie często i chętnie używane przez uczonych-specjalistów, jak i przez laików. O zachowaniach ludzi bądź zwierząt rozprawiają biolodzy i psycholodzy oraz wychowawcy; socjolodzy i prawnicy; zwykli ludzie w prywatnych rozmowach i ekonomiści. Wszędzie tam, gdzie przedmiotem zainteresowania stają się żywe organizmy, pojęcie zachowania odgrywa kluczową rolę.

Pojęcie zachowania jest jednym z tych pojęć, które uchodzi za jasne, precyzyjne i czysto opisowe. Gdy powołuję się na czyjeś motywy, przekonania, zamiary, poglądy czy odczucia, zawsze - można argumentować - jestem narażony na ryzyko błędu. Gdy zdaję sprawę z czyjegoś zachowania, nie spekuluję i nie oceniam, a tylko relacjonuję to, co należy do dziedziny ogólnie dostępnych faktów. Myśli, motywy, odczucia itd. można skrywać; zachowań w podobny sposób ukryć się nie da. Jednym z głównych motywów behawiorystów, zarówno tych o psychologicznym, jak i tych o filozoficznym rodowodzie, była chęć unaukowienia psychologii. Sprowadzając psychologię do opisu zachowań, uczyni się z niej, sądzono, naukę w prawdziwym znaczeniu tego słowa. Filozoficzne i psychologiczne mody bywają zmienne i behawioryzm nie jest już trendy. Zastąpiły go w tej roli różne odmiany funkcjonalizmu. Zmieniające się mody nie wpłynęły jednak na zaufanie, jakim cieszy się pojęcie zachowania. W dalszym ciągu stanowi ono stały i pewny punkt oparcia najrozmaitszych teorii umysłu.

W dalszym ciągu będę przekonywać, że pojęcie zachowania jest potrójnie niejasne. Po pierwsze, nie jest jasne (a przynajmniej nie dysponujemy żadnym czytelnym kryterium pozwalającym rozstrzygać te sprawy), które czysto fizyczne i dające się obserwować bardzo szeroko rozumiane ruchy pewnego organizmu należy zaliczać do zachowania. Po drugie, nie jest jasne, gdzie się zaczyna zachowanie, a po trzecie - nie jest jasne, gdzie ono się kończy. Omówimy te niejasności w takiej kolejności, w jakiej je wymieniłem. 


\section{Pierwsza niejasność}

O co chodzi w pierwszym przypadku, najlepiej i najszybciej wyjaśnimy za pomocą przykładu. Załóżmy, że ktoś przez pewien czas wielokrotnie zadaje mi pytanie: „Co robisz?”, a ja staram się na nie odpowiedzieć. Oto kilka przykładów moich odpowiedzi: Włączam telewizor, Zamykam drzwi, Odbijam twój obraz na siatkówce, Czytam gazetę, Wydzielam kwasy żołądkowe, Wychodzę na balkon, Spadam na dół z przyspieszeniem $9,81 \mathrm{~m} / \mathrm{sek}^{2}$. Otóż sądzę, że nikt lub prawie nikt nie miałby kłopotów $z$ oddzieleniem odpowiedzi sensownych od jawnie absurdalnych. Mogę powiedzieć, że to ja włączam telewizor, zamykam drzwi, wychodzę na balkon, czytam gazetę, ale nie - w odpowiedzi na pytanie: „Co robisz?” - że to ja odbijam twój obraz na siatkówce, wydzielam kwasy żołądkowe, spadam na dół z przyspieszeniem $9,81 \mathrm{~m} / \mathrm{se}^{2}$. Ja tych rzeczy nie robię. Są to czysto przyrodnicze wydarzenia, na które nie mam żadnego wpływu. Kwasy żołądkowe są po prostu wydzielane, ciało spada, a obraz na siatkówce jest odbijany.

Rozróżnienie, o które nam idzie, uchodzi - wszędzie tam, gdzie w grę wchodzą kontakty pomiędzy ludźmi - za zrozumiałe samo przez się i nie wymagające żadnych dalszych wyjaśnień. Opiera się na nim np. wymiar sprawiedliwości. Można ukarać Iksa za to, że tupnął nogą i spowodował osunięcie się lawiny; najsurowszy nawet prokurator nie domagałby się natomiast ukarania Iksa, gdyby wykazano, że to podmuch wiatru go przewrócił, a upadek spowodował osunięcie lawiny. Ludzie miewają do siebie pretensje wyłącznie o to, co sami zrobili, a nie o to, co po prostu się wydarzyło, nawet jeśli w wydarzeniach „brały udział” ciała ich bliźnich.. Rozróżnienie to (w praktyce) nie nastręcza na ogół trudności. Pan Iks może mieć żal do pana Igreka, że ten nie oddał mu książki; nie może mieć jednak pretensji o to, że Igrek wpadł na niego, gdy nagle zahamował autobus.

Rozróżnienie, o które nam idzie, jest już czytelne dla małych dzieci. Dzięki temu proces wychowywania dzieci jest w ogóle możliwy. Okrzyk matki: Co robisz!, gdy Jaś opluwa właśnie Małgosię, jest sensowny. Inny egzemplarz tego samego okrzyku w sytuacji, gdy Jaś miałby biegunkę lub gorączkę, byłby całkowicie absurdalny.

Aby odróżnić te dwa rodzaje zachowania, będę odtąd mówił o zachowaniu fizycznym i zachowaniu podmiotowym. Rozróżnienie pomiędzy zachowaniem fizycznym i podmiotowym ma olbrzymie znaczenie dla problemu wolnej woli. Wiedział już o tym św. Augustyn (choć nie używał wprowadzonych przeze mnie określeń). Jeżeli nie byłoby różnicy pomiędzy zachowaniem fizycznym i podmiotowym, to pojęcia odpowiedzialności, winy, kary, nagrody i zasługi tracą sens. Karać lub nagradzać można tylko za zachowanie podmiotowe. Rzecz jasna, nauki społeczne zainteresowane są tylko zachowaniem podmiotowym. Psychologa nie interesują ani ruchy ciał, zachodzące pod wpływem ziemskiego przyciągania (jest to domena fizyka), ani proces wydzielania kwasów żołądkowych (tym interesują się fizjolodzy i lekarze). Na wspomnianym rozróżnieniu polegają nie tylko psychologowie, lecz także prokuratorzy i sędziowie; nauczyciele i wychowawcy; oparte są na nim najbardziej elementarne kontakty międzyludzkie. Rzecz jasna, wszyscy ci ludzie i wszystkie te nauki, powołując się na pojęcie zachowania, mają na myśli 
tylko zachowanie podmiotowe, a nie czysto fizyczne. Jaka jest jednak podstawa tego rozróżnienia? Jeżeli kogoś nie zadowalają przykłady i intuicje, a oczekuje definicji i kryteriów, to znaleźlibyśmy się w kłopocie.

Jeżeli stoimy na gruncie tradycyjnej koncepcji człowieka, to nietrudno wskazać taką podstawę. Zachowanie jest podmiotowe, jeżeli jego źródłem, pierwszą przyczyną jest obdarzony wolną wolą działający podmiot. Oczywiście, musi to być podmiot we właściwym znaczeniu tego słowa - byt (tradycyjnie była to niematerialna ludzka dusza, ale są jeszcze inne możliwości), którego akty woli i działania nie należą do świata materialnej przyrody ani nie są przez nią bez reszty determinowane. W każdym razie nie może to być tylko czysto teoretyczna konstrukcja, taka jak np. Dennetta, gdzie podmiot jest środkiem ciężkości narracji językowej (Dennett 1991).

Jeżeli jednak przyjmiemy, że człowiek jest w całości częścią przyrody, jeżeli podmiotu w opisanym tutaj sensie nie ma, to wówczas pojęcie zachowania w jego tradycyjnym lub normalnym (czyli podmiotowym) znaczeniu traci sens. Wszelkie zachowanie staje się zachowaniem czysto fizycznym. Oczywiście można jeszcze wówczas mówić o zachowaniu, ale tylko w takim sensie, w jakim mówi się o zachowaniu tajfunu, rzeki lub wulkanu albo pralki automatycznej, samochodu lub komputera. Zmienia się wówczas wszystko. Jeżeli wybucha wulkan, nie prosimy o pomoc psychologa. Jeżeli komputer wykonał niewłaściwą operację, nie zawiadamiamy prokuratora.

\section{Druga niejasność}

Drugą niejasność można wyrazić za pomocą prostego pytania: Gdzie się rozpoczyna zachowanie? Istotę drugiej niejasności również najłatwiej i najszybciej uda nam się określić, podając odpowiednie przykłady.

Przykład 1. Do mózgu szczura wszczepiono 16 elektrod, dzięki którym rejestrowano czynności 30 neuronów (jednoczesny zapis jest ważny, gdyż aktywność jednego neuronu nie stanowi pełnej instrukcji umożliwiającej wykonanie odpowiedniego ruchu). Następnie naukowcy nauczyli szczura naciskania łapą dźwigni w celu otrzymania pokarmu, który był podawany za pomocą robota. Wreszcie (kluczowy moment!) skonstruowano sztuczną sieć neuronową, którą wykorzystano do rozpoznawania wzorców czynności neuronów, występujących podczas naciskania dźwigni. Gdy sieć rozpoznawała odpowiedni wzorzec, uruchamiała (za pośrednictwem robota) dźwignię i zwierzę otrzymywało pokarm. Ramię automatu reagowało szybciej niż mięśnie kończyny zwierzęcia, więc dostawało ono pokarm przed naciśnięciem łapą dźwigni. Po pewnym czasie szczur zauważył, że naciskanie łapą dźwigni jest zbędne i zaprzestał wykonywania tej czynności; niekiedy poruszał minimalnie łapą, a niekiedy nie wykonywał żadnego ruchu (,Świat Nauki", styczeń 2000). 
Załóżmy teraz, że nasz szczur uległ całkowitemu i nieuleczalnemu paraliżowi, ale że mózg zwierzęcia pracuje bez zarzutu, a w każdym razie, że bez zarzutu (czyli tak, jak przedtem) działa 30 neuronów, do których podłączono 16 elektrod. Nie ulega wątpliwości, że szczur mógłby w dalszym ciągu uruchamiać dźwignię (za pośrednictwem odpowiednich artefaktów) i tą drogą uzyskiwać pokarm. Jeżeli w ogóle chcemy mówić o czymś takim, jak zachowanie szczura, to musimy uznać, że uruchamianie dźwigni jest częścią jego wyuczonego zachowania.

Przykład 2. Naukowcy z Emory University wszczepili sparaliżowanej ofierze udaru mózgu układ scalony pozwalający jej za pomocą fal mózgowych sterować kursorem na ekranie komputera. („Świat Nauki”, grudzień 1999).

Zauważmy, że sterowanie kursorem na ekranie komputera jest, jak się wydaje, typowym zachowaniem podmiotowym. Zauważmy ponadto, że ktoś, kto potrafi sterować zachowaniem komputera, potrafi też - via odpowiednie artefakty - robić wiele innych rzeczy. Osoba taka może chociażby kontrolować zachowanie wielu różnych urządzeń i obiektów, np. w tzw. inteligentnym domu. Osoba taka może - via odpowiednie artefakty - gasić i zapalać światło, korzystać z telewizora, uruchamiać i zatrzymywać windę, otwierać i zamykać okna itd., itd. We wszystkich tych przypadkach mówienie o robieniu, działaniu lub zachowaniu podmiotowym wydaje się całkowicie uzasadnione. Nie można pozbawiać ludzi podmiotowości tylko na tej podstawie, że nie są w stanie poruszać kończynami!

Rozprawianie o zachowaniu ludzi całkowicie sparaliżowanych może się jednak wydać dziwactwem i to nie tylko dlatego, że nie jesteśmy do tego przyzwyczajeni. llekroć mówimy o zachowaniu podmiotowym, o robieniu czegoś, automatycznie szukamy pośrednictwa ręki, nogi, głowy, języka itd. Jeżeli Jaś zgasił światło, to musiał posłużyć się jakąś częścią swego ciała - ręką, nogą, głową itd. Jakże więc całkowicie sparaliżowany Jaś mógł coś zrobić, skoro jego ręce, nogi, głowa są nieruchome?! Odczuwamy dyskomfort - brakuje nam pośrednictwa stosownego organu. I właśnie dlatego proponujemy nowe określenie. Od tej pory będziemy mówili o działaniu neuronami lub po prostu o robieniu czegoś neuronami. Przyjmujemy zatem, że Jaś może zgasić światło ręką lub nogą lub - niekiedy - neuronami.

Robienie czegoś neuronami lub za pomocą neuronów chcemy rozumieć analogicznie do robienia innych rzeczy, np. za pomocą rąk. Ktoś może, posługując się rękami, włączyć telewizor lub zgasić światło; ktoś inny może zrobić to samo, używając neuronów. Czy wobec tego należałoby mówić o zachowaniu mózgu, dodajmy, podmiotowym zachowaniu mózgu i przyjąć, że gdzieś w obrębie czaszki rozpoczyna się zachowanie, coś, czego nie widać gołym okiem, ale co, w zasadzie, można obserwować?

Na zakończenie jeszcze jeden przykład, mogący wesprzeć moje sugestie.

Przy kład 3. Załóżmy, że Jan i Piotr siedzą sobie wygodnie w fotelach $w$ takich samych pozycjach i nic nie robią. Ktoś zadaje im pytania, a oni odpowiadają na nie przez cały czas (załóżmy to) tak samo. Czy Jan i Piotr zachowują się tak samo? Odpowiedź na to pytanie nie jest wcale prosta. Otóż Jan i Piotr podłączeni są do wariografu. Rzecz w tym, że chociaż siedzą w takich samych pozycjach, w takich samych fotelach i mówią takie same rzeczy, to rysiki wariografów, do 
których są podłączeni rysują całkowicie różne krzywe. Otóż pytanie, na które powinniśmy umieć odpowiedzieć brzmi: Czy krzywe kreślone przez rysiki wariografów są integralną częścią zachowania? Jeżeli odpowiemy na to pytanie twierdząco, to będziemy musieli uznać, że zachowanie obu panów różni się zasadniczo. Specjalista obsługujący wariografy mógłby powiedzieć, że zachowanie to świadczy o tym, że Jan mówi prawdę, a Piotr kłamie jak najęty.

Czy można mówić o czymś takim jak zachowanie mózgu? Nasz punkt wyjścia jest następujący. Aby sprawdzić, czy ktoś jest szczery, podłącza się mózg do odpowiedniego skanera. Innymi słowy mózg, którego właściciel w świadomy sposób kłamie, zachowuje się w całkiem określony sposób, inny niż mózg człowieka, który jest szczery. W pierwszym przypadku aktywna staje się cała sieć neuronów, które hamują ujawnienie prawdy. Cała ta „sieć kłamstwa” pozostaje natomiast nieaktywna, gdy badany jest szczery. Można to obserwować na odpowiednim monitorze.

Oczywiście, w „świecie neuronów” dzieje się wiele różnych rzeczy, o których z pewnością nie mogę powiedzieć, że to ja je robię. Zapewne nie reguluję za pomocą neuronów rytmu serca, nie zmieniam poziomu cukru we krwi itd. Wszystkie te rzeczy po prostu zachodzą lub wydarzają się, a ja nie mam na nie żadnego wpływu. W świecie dających się obserwować zachowań mego ciała też jednak dzieje się wiele różnych rzeczy, których nie kontroluję i na które nie mam żadnego wpływu, np. chrapanie lub kichanie. W jednym i drugim przypadku mamy do czynienia zarówno z zachowaniami podmiotowymi, jak i fizycznymi.

Mówienie o działaniu neuronami i zachowaniu mózgu, w sytuacji, gdy nasze naturalne środowisko w coraz większym stopniu zaczyna zawierać artefakty wrażliwe na wydarzenia zachodzące w mózgu ma swoje konsekwencje. Jeżeli za pomocą neuronów będziemy sterować wieloma różnymi ważnymi urządzeniami; jeżeli w ten sam sposób będzie można sterować samolotem lub wystrzelić rakietę i zburzyć wielkie miasto, to pojęcie zachowania ulegnie całkowitej zmianie. Oto dwie uwagi.

Uwaga 1. Do tej pory to, co działo się (zachodziło) w obrębie skóry pewnego człowieka, nie należało do zachowania (wszystko jedno, podmiotowego czy przedmiotowego). Człowiek mógł myśleć, marzyć, planować, kochać, lubić, nienawidzić i jeżeli nie znajdowało to zewnętrznego wyrazu, nikogo to nie obchodziło. Jeżeli jednak za pomocą neuronów będzie można wysłać maila, kontrolować lot samolotu lub wystrzelić rakietę, to pojęcie zachowania będzie musiało zostać rozciągnięte na świat neuronów. Jeżeli pojęcia odpowiedzialności, winy, kary, pretensji, zasługi itd. miałyby zachować sens, to musielibyśmy nauczyć się odróżniać podmiotowe zachowanie neuronów od czysto fizycznego. Czy uda się to zrobić, kto i na jakiej podstawie ma o tym decydować - to już osobna kwestia.

U wa ga 2. Od niepamiętnych czasów ludzie działali, posługując się rękami, nogami itd. W miarę rozwoju nauki i techniki ręce i nogi są jednak wyręczane przez coraz to doskonalsze maszyny. Za pomocą odpowiednich maszyn można zrobić więcej, lepiej, dokładniej, szybciej. Czy analogiczny proces obejmie także działanie neuronami?

Wyobraźmy sobie pilota wojskowego samolotu, który wystrzeliwuje rakiety skierowane na wrogie cele za pomocą neuronów. Jest to zupełnie analogicz- 
ne do przykładu ze szczurem. Uruchomienie rakiety za pomocą neuronów jest po prostu szybsze. Odbywa się to mniej więcej w ten sposób. Pilot na odpowiednim monitorze spostrzega wrogi cel. Podejmuje decyzję o wystrzeleniu rakiety. Naciśnięcie palcem na odpowiedni przycisk zajmuje więcej czasu niż wystrzelenie rakiety (via odpowiednie artefakty) neuronami. Czy można jeszcze skrócić ten czas? Neurochirurg Benjamin Libet wykazał w serii eksperymentów (Benjamin Libet 1985), że 550 milisekund przed podjęciem świadomej decyzji o wykonaniu ruchu (a w każdym razie przed uświadomieniem sobie, że podjęło się taką decyzję) pojawia się w mózgu tzw. potencjał gotowości (odpowiednie ośrodki w mózgu są w odpowiedni sposób pobudzone). Z grubsza biorąc, cały scenariusz wygląda mniej więcej tak. Wpierw pojawia się w mózgu odpowiedni potencjał gotowości, następnie, 350 milisekund później, podejmuję świadomą decyzję (lub uświadamiam sobie, że mózg podjął taką decyzję), następnie, 200 milisekund po podjęciu świadomej decyzji wykonuję ruch. Otóż, z militarnego punktu widzenia byłoby niesłychanie korzystne, gdybyśmy do wystrzelenia rakiety wykorzystali wspomniany potencjał gotowości. Zyskuje się w ten sposób całe 550 milisekund. $Z$ technicznego punktu widzenia nie powinno to być trudne. Skoro potencjał gotowości jest w stanie wpłynąć na działanie elektrod, to (via odpowiednie artefakty) byłby również w stanie spowodować wystrzelenie rakiety. Z pewnością można byłoby wykorzystać te ośrodki do wystrzelenia rakiety. Cała sekwencja wyglądałaby teraz tak. Pilot widzi na monitorze wrogi samolot, pojawia się w mózgu potencjał gotowości, w tym samym momencie rakieta zostaje wystrzelona, a w 350 milisekund później pilot podejmuje świadomą decyzję o wystrzeleniu rakiety. Czy w tej sytuacji można jeszcze mówić o odpowiedzialności, winie, karze itd., krótko mówiąc o tzw. zachowaniu podmiotowym? Wydaje się, że nie. W eksperymentach Libeta działający podmiot może niekiedy, nawet po pojawieniu się odpowiedniego potencjału gotowości, zablokować wykonanie ruchu. Tym razem nie ma takiej możliwości. Rakieta jest wystrzeliwana przez, w dosłownym znaczeniu tego słowa, potencjał gotowości. Załóżmy, że pilot zestrzelił samolot sojuszniczy. Najlepszym tłumaczeniem ze strony pilota byłoby: „Proszę kierować pretensje do potencjału gotowości. Nie ja go spowodowałem tylko obraz, który się pojawił na ekranie monitora". I w ten sposób świadomy i działający podmiot zostałby całkowicie wyeliminowany z gry. Prokurator, wychowawca, moralista i psycholog nie mieliby tu nic do roboty. Byłby to problem dla neurobiologa, informatyka-programisty i inżyniera. Pospekulujmy trochę. Jest to ulubione zajęcie filozofów. Załóżmy, że zespół złożony z neurobiologów, inżynierów i programistów orzekł, że działanie całego systemu można będzie znacznie ulepszyć (tzn. potencjał gotowości będzie się mylił znacznie rzadziej), o ile niektóre neurony w mózgu pilota zostaną zastąpione odpowiednimi artefaktami... Wydaje się, że właśnie w ten sposób mógłby się rozpocząć proces przebudowy ludzkich organizmów. 


\section{Trzecia niejasność}

Zajmijmy się teraz innym problemem, a mianowicie próbą odpowiedzi na pytanie, gdzie kończy się zachowanie. Odpowiedź na to pytanie zawsze była trudna. W dobie rewolucji naukowo-technicznej problem jest jednak szczególny. Spróbujmy wyjaśnić, co mamy na myśli. Oto kilka typowych opisów zachowań pewnego hipotetycznego człowieka w tym nowym środowisku. Włączył telewizor (za pomocą pilota), Przegrał tekst na dyskietkę, Nastawił pralkę na płukanie, Skierował samochodzik do "tunelu" utworzonego z klocków (o chłopcu sterującym samochodzikiem-zabawką za pomocą pilota), Wysłał maila do Agaty itd., itd. Opisy te zdają się należeć do tej samej kategorii zachowań, co np. Wstał z łóżka, otworzył okno lub zamknął drzwi. Opisując poranne zachowanie pewnego X-a, moglibyśmy np. powiedzieć: $X$ wstał z łóżka, otworzył okno, włączył komputer i wysłał maila do Agaty.

Załóżmy teraz, że opisujemy dwa zachowania pewnego pana o imieniu Jan. Opisy dotyczą dwóch różnych dni tygodnia, środy i czwartku.

Środa. Jan wstał z łóżka, otworzył okno, włączył komputer i wysłał maila do Agaty.

Czwartek. Jan wstał z łóżka, otworzył okno, włączył komputer i wysadził most w powietrze.

Jan „środowy” to niczym się niewyróżniający, porządny obywatel, Jan „czwartkowy" - to groźny terrorysta.

Załóżmy dalej, że w mieszkaniu Jana zainstalowano cały szereg ukrytych kamer i czujników. Zadaniem tych urządzeń jest rejestrowanie wszelkich zachowań Jana. Kamery rejestrują ruchy ciała, a odpowiednie czujniki nawet siłę, z jaką Jan uderza w przyciski klawiatury podłączonej do komputera. Otóż okazuje się, że czwartkowe zachowanie Jana nie różniło się niczym istotnym od środowego. Jan wstał z łóżka, otworzył okno, włączył komputer, po czym naciskał te same klawisze, co we środę, z taką samą (mniej więcej) siłą i w takiej samej kolejności; najeżdżał myszką na takie same ikonki i klikał lewym lub prawym przyciskiem tej samej myszki z (mniej więcej) taką samą siłą, co we środę itd., itd. Czwartkowe zachowanie Jana było, rzec można, behawioralnym cieniem jego zachowania środowego. Eksperci analizujący środowe i czwartkowe zachowanie Jana w oparciu o zarejestrowane historie byli zdumieni stopniem podobieństwa i dopiero po pewnym czasie i nie bez trudu nauczyli się odróżniać Jana „środowego" od Jana „czwartkowego”.

Skoro jednak Jan we środę i w czwartek zachowywał się (w wyjaśnionym właśnie znaczeniu) tak samo, to dlaczego w środę wysłał maila do Agaty, a we czwartek wysadził most w powietrze? I, po drugie, jakże można twierdzić, że zachowywał się tak samo, jeżeli za pierwszym razem wysłał maila do Agaty, a za drugim wysadził most $w$ powietrze. Nie są to chyba takie same zachowania.

Po kolei. Jan zachowywał się tak samo w znaczeniu, które starałem się wyjaśnić. Uderzał $w$ takie same klawisze (tak samo dla niego wyglądające), w tej samej kolejności, z taką samą siłą itd. Rzecz jednak w tym, że środowisko, w którym przyszło działać Janowi uległo całkowitej, choć niezauważalnej dla Jana zmianie. Otóż groźni terroryści, bez wiedzy i zgody Jana, w czasie, 
gdy spał, a kamery i czujniki były wyłączone, wymienili komputer Jana na bliźniacze i bliźniaczo interaktywne (w interesującym nas zakresie) urządzenie, służące (via inne artefakty) do wysadzenia w powietrze określonego mostu. Jan robił to samo, co we środę, ale tym razem, miast wysłać maila do Agaty, wysadził most w powietrze. Czy jednak można powiedzieć, że to Jan wysadził most w powietrze? Niezależny sąd, po rozważeniu wszystkich okoliczności, zapewne uwolniłby Jana od winy i kary. To nie Jan wysadził most w powietrze. Jan tylko wciskał określone klawisze i najeżdżał kursorem myszki na określone ikony... Jeżeli jednak wysadzenie mostu w powietrze nie jest częścią zachowania Jana, to dlaczego miałoby nim być (środowe) wysłanie maila do Agaty? Być może tym razem też należałoby powiedzieć, że Jan po prostu wciskał określone klawisze. Dlaczego we środę mielibyśmy stosować inne kryteria niż we czwartek? Pytanie, które nas gnębi, moglibyśmy sformułować tak: „Gdzie kończy się zachowanie Jana?!" Na pytanie w ten sposób sformułowane zapewne nie ma całkowicie ścisłej i dobrej odpowiedzi. Być może jednak próby uzyskania tej odpowiedzi pozwolą nam lepiej zrozumieć istotę wchodzących tu w grę trudności. Nim posuniemy się dalej, musimy poszerzyć krąg naszych rozważań i wprowadzić pewne rozróżnienia. Rozpocznijmy od kilku uwag.

Otóż, po pierwsze, mówienie o zachowaniu zawsze zakłada obecność pewnego środowiska. Propozycja, aby poprzez zachowanie rozumieć po prostu ruchy ciała opisywane względem pewnego układu współrzędnych jest bałamutna. Powiedzenie, że pewien $X$ podniósł rękę, bez wyjaśnienia, w jakim środowisku to zrobił, nie mówi nam niczego o zachowaniu. Czymś innym jest podniesienie ręki w wodzie, czymś innym w powietrzu czymś innym na Ziemi i czymś innym na Księżycu. Są to cztery różne zachowania. Opis zachowania (nawet, jeśli chcemy mówić tylko o ruchach ciała) wymaga relatywizacji do środowiska.

To samo dotyczy tzw. dyspozycji zachowaniowych. Dyspozycja jest zawsze dyspozycją do określonych zachowań w określonym środowisku.

Naturalnym środowiskiem współczesnych ludzi (tzn. tym środowiskiem, w którym wzrastają i z którym niekiedy obcują przez większą część dnia) są coraz częściej i w coraz większym stopniu różnego rodzaju artefakty. Nazwijmy to środowisko środowiskiem elektronicznym. Tym, czego dotykamy, co widzimy, z czym stykamy się bezpośrednio i nad czym mamy kontrolę są jednak coraz częściej po prostu klawisze i monitory pewnych urządzeń. Nazwijmy to środowisko środowiskiem klawiaturowym. Oczywiście, środowisko elektroniczne i środowisko klawiaturowe - to dwa zupełnie różne byty. Idąc śladem tego rozróżnienia, będziemy od tej pory mówili o zachowaniu elektronicznym i - odpowiednio - o zachowaniu klawiaturowym. Oczywiście, zachowanie elektroniczne i zachowanie klawiaturowe - to dwa całkowicie różne zachowania. Dwa zachowania mogą być identyczne klawiaturowo i całkowicie różne elektronicznie. Zachowanie klawiaturowe Jana we środę i w czwartek było takie samo (lub prawie takie samo), natomiast jego zachowania elektroniczne były całkowicie różne; za pierwszym razem wysłał maila do Agaty, a za drugim (przy takim samym zachowaniu klawiaturowym) - wysadził most w powietrze. Wszystkie podawane do tej pory przykłady różnych zachowań: Włączył telewizor (za pomocą pilota), Przegrał tekst na dys- 
kietkę, Nastawił pralkę na płukanie, Skierował samochodzik do „tunelu” utworzonego z klocków (o chłopcu sterującym samochodzikiem-zabawką przy pomocy pilota), Wysłał maila do Agaty, to przykłady zachowań elektronicznych. Gdybyśmy chcieli ograniczyć się do opisu zachowań klawiaturowych, to moglibyśmy mówić tylko o klawiszach, myszkach, monitorach i pokrętłach. Kilka dalszych uwag na ten temat pomoże lepiej zrozumieć proponowane rozróżnienia.

Środowisko klawiaturowe jest na ogół w określony sposób sprzężone ze środowiskiem elektronicznym i, co za tym idzie, określone zachowania klawiaturowe prowadzą w olbrzymiej większości przypadków do określonych i z góry przez nas przewidywanych zachowań elektronicznych. Troszczą się o to eksperci. Toteż, o ile wszystko działa tak, jak powinno, nie myślimy o zachowaniach klawiaturowych, a w typowych opisach ludzkich zachowań w ogóle nie wspominamy o klawiszach. Zaczynamy sobie uświadamiać, że coś takiego jak zachowanie klawiaturowe w ogóle istnieje dopiero wówczas, gdy artefakty nas zawodzą. Wcisnąłem te same klawisze, co zazwyczaj, a jednak tym razem...

Problem, z którym się zmagamy nie jest „przywiązany” do elektroniki i klawiszy. Weźmy np. pod uwagę następujący opis zachowania Jacka. Jacek zastrzelił Piotra z dubeltówki. Załóżmy dalej, że Jacek wielokrotnie wcześniej celował do Piotra z dubeltówki i naciskał spust. Był to taki rodzaj zabawy, a dubeltówka, z której korzystał Jacek była zepsuta i od lat nieużywana. Pewnego razu, w fatalny czwartek, Jacek, jak zwykle, wziął dubeltówkę, wycelował w Piotra i, śmiejąc się, nacisnął spust. Tym razem dubeltówka wypaliła, strzał był celny i Piotr zmarł. Otóż w nocy, przebiegły X-iński (pragnący się pozbyć Piotra i wiedzący o jego zabawach z Jackiem), bez wiedzy i zgody tego ostatniego, zreperował dubeltówkę i załadował ją ostrą amunicją. W opisanej sytuacji odczulibyśmy potrzebę wprowadzenia analogicznych rozróżnień, a mianowicie na „zachowanie klawiaturowe” (naciśnięcie spustu) i na „zachowanie elektroniczne” (zastrzelenie Piotra).

Nasuwa się następujące pytanie: Który z proponowanych opisów jest właściwym lub prawdziwym opisem zachowania Jana, Jacka itd. - klawiaturowy czy elektroniczny? Zarówno Jan, jak i Jacek mogli, odpowiednio, wysadzić most i zastrzelić Piotra z pełnym rozmysłem. I znowu ich zachowania klawiaturowe byłyby (odpowiednio) takie same. A ponadto, klawiatura Jana mogłaby zostać odłączona od środowiska elektronicznego, a Jan mógłby o tym wiedzieć lub nie. I znowu zachowania klawiaturowe byłyby takie same.

Wydaje się, że powinniśmy rozpatrzyć następujące przypadki:

(a) Jan miał zamiar wysłać maila do Agaty i zrobił to.

(b) Jan miał zamiar wysłać maila do Agaty, ale wysadził (niechcący) most w powietrze.

(c) Jan miał zamiar wysadzić most w powietrze (wiedział skądinąd o manipulacji, której dokonali terroryści) i wysadził most w powietrze.

(d) Jan miał zamiar wysadzić most w powietrze, ale (niechcący) wysłał maila do Agaty (terrorystom nie udało się dokonać stosownych zmian w systemie).

(e) Klawiatura jest odcięta od środowiska elektronicznego, ale Jan o tym nie wie i (dzięki sprytnemu programowi, który uruchamia się samoczynnie) sądzi, że wysyła maila do Agaty. 
(f) Klawiatura jest odcięta od środowiska elektronicznego, ale Jan o tym nie wie i (dzięki sprytnemu programowi, który uruchamia się samoczynnie) sądzi, że wysadza most w powietrze.

(g) Klawiatura jest odcięta od środowiska elektronicznego, Jan o tym wie i klikając odpowiednimi przyciskami (załóżmy, że towarzyszy temu jakieś demo) demonstruje po prostu, w jaki sposób wysyła się maila do Agaty.

We wszystkich tych przypadkach - załóżmy to - zachowania klawiaturowe Jana były identyczne; z taką samą siłą i z równym zapałem wciskał i klikał na stosowne przyciski. Nie ulega jednak wątpliwości, że w każdym z tych przypadków inaczej powinny brzmieć opisy zachowania Jana. Najłatwiejsze do oceny są przypadki (a), (b) oraz (g). W przypadkach (a) i (b) najwłaściwszy byłby opis elektroniczny; tzn. na pytanie: Co zrobił Jan, odpowiedzielibyśmy po prostu: Wysłał maila do Agaty $\mathrm{i}$, odpowiednio, Wysadził most w powietrze. W przypadku (g) najwłaściwszy byłby opis czysto klawiaturowy. W pozostałych przypadkach odczulibyśmy potrzebę oddzielenia zachowania klawiaturowego od elektronicznego, a z odpowiedzią na pytanie, co właściwie zrobił Jan mielibyśmy kłopoty. Weźmy np. jeszcze raz pod uwagę przypadek (b). Zarówno opis elektroniczny (Jan wysadził most w powietrze), jak i opis klawiaturowy (Jan klikał takie to a takie przyciski w takiej to a takiej kolejności) wydają się niestosowne. Moglibyśmy skopiować punkt (b) i napisać po prostu, że "Jan miał zamiar wysłać maila do Agaty ale wysadził (niechcący) most w powietrze". Z tym, że zdanie wzięte w cudzysłów nie jest opisem zachowania Jana.

Morał, jaki z tego wynika, jest całkiem banalny i brzmi następująco: Opis zachowania Jan zależy od jego zamiarów. Zamiary tradycyjnie umieszczano w niematerialnym umyśle, do którego dostęp miał tylko sam ten umysł. Ponieważ jednak - jak utrzymują naturaliści - takiego umysłu nie ma, to zamiary (o ile w ogóle istnieją) musiałyby się jakoś manifestować w zachowaniu mózgu. Czy jednak byłoby to jeszcze zachowanie podmiotowe?

\section{Addenda}

Oto dziwny przypadek, dla którego nie znalazłem miejsca w głównym tekście.

Zawsze było tak, że wilk zachowywał się (tak lub inaczej) za pomocą ciała wilczego, tygrys za pomocą tygrysiego, człowiek ludzkiego... a karaluch biegał, zatrzymywał się, skręcał w lewo lub w prawo za pomocą ciała karalucha. Tak zawsze było, ale tak - okazuje się - być nie musi. Widziałem (w telewizji, w czasie programu poświęconego sztucznej inteligencji), jak pewien człowiek sterował karaluchem za pomocą pilota. Ciało karalucha biegało, stawało, skręcało w lewo lub w prawo..., ale to nie karaluch robił to wszystko, tylko człowiek z pilotem, który sterował ciałem karalucha zupełnie tak samo jak chłopiec samochodzikiem-zabawką. Rewolucja komputerowa i biologiczna „podały sobie ręce” i wspólnymi siłami przekształciły żywą istotę, za pośrednictwem implantów i pilotów, w bezwolny artefakt. Niektórych to fascynuje, a niektórych przeraża.. Ewolucja karalu- 
chów trwała miliony lat. W tym czasie miliony karaluchów ginęły (tych gorzej przystosowanych), a miliony innych przeżywały i rozmnażały się. Wreszcie przybrały postać, dzięki której są w stanie sprostać wyzwaniom środowiska. I wszystko to na nic. Oto pojawia się człowiek z pilotem, który wbrew jego (karalucha) najoczywistszym interesom i potrzebom może go skierować w ogień lub do walącego się budynku, lub do mrowiska, lub „posłać” jego ciało do beznadziejnej walki ze znacznie silniejszym przeciwnikiem. Jednym puknięciem palca w odpowiedni klawisz człowiek w fotelu przekreśla wiele milionów lat ewolucji i potrafi uczynić zachowanie karalucha (zachowanie ciała karalucha) szalonym. Człowiek z pilotem potrafi sprawić, że ciało karalucha będzie robiło rzeczy, które nigdy nie były robione przez żadne ciało żadnego karalucha. Gdy jedna żywa istota ma aż taką przewagę nad drugą żywą istotą, to zaczyna to być straszne.

Czy to co udaje się w przypadku karaluchów, byłoby możliwe w przypadku ludzi? Czemu nie, powiedziałby naturalista. Wszak ludzie, podobnie jak karaluchy, są w całości częścią materialnej przyrody. To tylko kwestia stosownej wiedzy i odpowiedniego pilota.

A co w takiej sytuacji z teleosemantyką (Millikan 1984, 1989). Jak należy wtedy rozumieć właściwe funkcje różnych organów? A jeśli na dodatek ludzie nauczą się wytwarzać karaluchy (w jakichś fabrykach karaluchów) i częściowo zmieniać budowę i możliwości ich ciał. Czy teleosemantyka w odniesieniu do tak powstałych karaluchów miałaby jeszcze jakiś sens?

Ale powróćmy do zachowania. Otóż ktoś oglądający karalucha, ale nic niewiedzący o człowieku i pilocie, np. jakiś behawiorysta specjalizujący się w karaluchach, byłby niesłychanie zdumiony zachowaniem karalucha, idącego śmiało przez ogień. Załóżmy, że nie jest to behawiorysta-filozof analityczny, próbujący zdefiniować terminy mentalne za pomocą zachowaniowych, ale behawiorysta typu bodziec-reakcja. Załóżmy dalej, że nasz behawiorysta w pewnym momencie dowiaduje się o człowieku i pilocie. Pytanie, na które chciałbym znać odpowiedź (ciekawe, co powiedziałby ów behawiorysta) brzmi: Czy to co obserwujemy jest zachowaniem karalucha, czy zachowaniem człowieka?

Oto kilka możliwych odpowiedzi.

Odpowiedź 1. To, co obserwujemy, to oczywiście w dalszym ciągu zachowanie karalucha. Człowiek z pilotem jest wszak częścią środowiska, w którym żyje i zachowuje się karaluch. Środowisko to nieustannie „atakuje” karalucha ogromną liczbą bodźców. Niektóre są słabe, niektóre silne. Bodźce pochodzące od człowieka z pilotem są bardzo silne, piorunująco silne, ale w końcu są to tylko bodźce, na które karaluch reaguje w określony sposób. Opisana sytuacja w dalszym ciągu mieści się w schemacie bodziec-reakcja.

Gdy szeregowiec biega, pada i wykonuje zwroty pod wpływem komend kaprala, to czy należałoby mówić w dalszym ciągu o zachowaniu szeregowca, a kapral byłby elementem środowiska, czy też raczej należałoby mówić o zachowaniu kaprala za pomocą ciała szeregowca?

Odpowiedź 2. To, co obserwujemy, to oczywiście zachowanie człowieka, a nie karalucha. Karaluch w opisywanej sytuacji został zmieniony w maszynę, 
którą kieruje w pełni człowiek. To człowiek przyspiesza, zwalnia, skręca w lewo lub w prawo... ciałem karalucha, zupełnie tak jak kierowca samochodu przyspiesza, zwalnia, skręca w lewo lub w prawo. Przyjęcie sugestii opisanej w pierwszej odpowiedzi szybko doprowadziłoby do absurdów.

Załóżmy, że akceptujemy drugą odpowiedź. Nasuwa się wówczas cały szereg dalszych pytań i wątpliwości. Otóż jeżeli akceptujemy drugą odpowiedź, to musimy przyjąć, że zachowanie obserwowanego przez nas człowieka obejmuje nie tylko jego ruchy (uderzenia w klawisze pilota), lecz także - a może nawet przede wszystkim - ruchy ciała karalucha, a to mogłoby w różnych sytuacjach prowadzić do dziwnych wniosków.

Trochę spekulacji. Załóżmy, że ktoś jest kompletnie sparaliżowany, ale steruje za pomocą neuronów (via inne artefakty) karaluchem. Nauczył się robić ciałem karalucha wszystko to (a nawet więcej), co robi karaluch. Co oznaczałoby bycie behawiorystą w odniesieniu do takiego człowieka? Ludzki mózg miałby do dyspozycji niewielkie ciało karalucha. Aby historia ta miała sens, należałoby ją rozbudować o wiele dalszych szczegółów, które mogłyby pójść w bardzo różnych kierunkach. Jeden spośród wielu możliwych byłby następujący. Sparaliżowany człowiek za pomocą ciała karalucha nauczył się obsługiwać komputer i komunikuje się z ludzką społecznością w normalny sposób. Zaczyna grać w gry komputerowe i w grach tych wybiera różne ciała... Przyjmijmy jednak, że komunikacja via komputer jest niemożliwa. Przyjmijmy dalej, że jedynym dostępnym środowiskiem dla naszej hybrydy (ludzki mózg - ciało karalucha) jest naturalne środowisko karaluchów. Interesuje mnie odpowiedź na pytanie, co w takiej sytuacji miałby oznaczać behawioryzm? Jakże niewiele mógłby wyrazić potężny ludzki mózg za pomocą ciała karalucha. Zaiste, z pełnym przekonaniem i jakże prawdziwie ktoś taki mógłby powtórzyć za Platonem: Ciało jest więzieniem dla duszy!

Załóżmy, że ktoś bardzo dobry z natury (ktoś taki jak św. Franciszek) i ktoś bardzo zły z natury (ktoś taki jak Kuba Rozpruwacz) ulegają paraliżowi, a ponieważ ich mózgi są sprawne, otrzymują do dyspozycji ciała karaluchów. Obserwując w lesie te ciała, jak niewiele moglibyśmy powiedzieć o jednym i o drugim. Dwie tak różne dusze (mózgi) zostałyby nieomal zrównane poprzez swe ciała. Jakież ogromne możliwości (chociaż zupełnie różnej natury) nigdy nie ujawniłyby się i nie zostały zrealizowane! Ktoś obserwujący tylko ciała karaluchów, nawet by nie przeczuwał ich istnienia. Jakże niewiele ludzki mózg mógłby wyrazić za pomocą ciała karalucha! 


\section{Rozdział piaty}

\section{PROBLEM WOLNEJ WOLI}

\section{Kilka uwag wstępnych}

Załóżmy, że pewnego razu pani Agnieszka pożyczyła panu Piotrowi pewną sumę pieniędzy, a ten solennie obiecał, że zwróci je w najbliższy wtorek o godz. 10 w umówionym miejscu. Minęło kilka dni, właśnie jest wtorek, zegary wskazują godz. 10, pani Agnieszka czeka w umówionym miejscu, a pana Piotra nie ma.. Nie przyszedł. Co dzieje się dalej? Dzieje się (lub raczej może się dziać) wiele różnych rzeczy, ale nas interesuje tylko jedna. Otóż, pani Agnieszka ma (słuszny, jak byśmy powiedzieli) żal lub pretensje do pana Piotra o to, że ten nie wywiązał się z wcześniej złożonej obietnicy.

Zachowanie pana Piotra jest moralnie naganne i (pozwólmy sobie na ten luksus) potępiamy pana Piotra. Takie rzeczy się niestety zdarzają, ale na czym polega filozoficzny problem? O filozoficznym problemie będzie za czas jakiś, a na razie po prostu zauważmy, że tego rodzaju żale lub pretensje miewają wyłącznie ludzie i wyłącznie w stosunku do innych ludzi. Tak więc nie mamy żalu do chmury, że nadciągnęła i spadł deszcz, ani do rzeki, że wylała i zniszczyła zbiory, ani do wulkanu, że wybuchł i spowodował śmierć wielu ludzi itd., itd. Podobny stosunek (pod interesującym nas względem) mamy nie tylko do chmur, rzek, wulkanów i innych zjawisk przyrody, lecz także do artefaktów. Tak więc nie miewamy ani żalu, ani pretensji do samochodu, że nie zapala, do komputera, że się zawiesił itd. O ile mi wiadomo, nawet najzagorzalsi fani sztucznej inteligencji nie miewają żalu ani pretensji (póki co) do najbardziej nawet zaawansowanych pod względem technicznym robotów. Ponieważ nie chciałbym zostać oskarżony o szowinizm białkowy, gotów jestem przyznać, że być może w przyszłości sytuacja ulegnie zmianie, ale na razie jest tak, jak jest.

A co ze zwierzętami? Stosunek wielu ludzi (w tym autora tej książki) do wielu zwierząt nacechowany jest silnymi emocjami. Czy wśród tych emocji są i takie, 
które przypominają żal lub pretensje odczuwane przez panią Agnieszkę w stosunku do pana Piotra z powodu niewywiązania się z wcześniej złożonej obietnicy? Wydaje się, że nie, a to choćby z tego powodu, że zwierzęta nie są w stanie wywiązywać się lub nie wywiązywać ze złożonych kilka dni wcześniej obietnic; a nie są tego w stanie robić choćby dlatego, że w ogóle nie potrafią składać obietnic. Broniąc się przed zarzutem szowinizmu gatunkowego, oświadczam, że jestem przekonany, iż wiele zwierząt posiada bogate życie wewnętrzne, a ponadto jestem zwolennikiem zapewnienia zwierzętom ochrony prawnej. Uwagi moje zmierzają tylko do uprzytomnienia sobie, że ewentualne żale i pretensje, których adresatem są zwierzęta mają zupełnie inny charakter niż te, których adresatem są ludzie i rzadko (lub prawie nigdy) przeradzają się w moralne potępienie. Tak więc nie mamy żalu czy pretensji ani do komara, że użądlił (chociaż może nas to złościć), ani do psa, że nas ugryzł (co najwyżej do jego właściciela, że nie założył mu kagańca); nie mamy pretensji, żalu, nie potępiamy Iwów za to, że polują na antylopy (chociaż wielu ludzi ma o to pretensje i żal do myśliwych, a ich postępowanie uważa za moralnie naganne i zasługujące na jednoznaczne potępienie) itd., itd. Niektórzy obrońcy praw zwierząt sugerują, że małpy człekokształtne są istotami tak wysoko rozwiniętymi, że w zasadzie powinny być zaliczone do rodzaju ludzkiego i, co za tym idzie, powinny im przysługiwać ludzkie prawa. Inicjatywa piękna, pomysł znakomity i zapewne jest wiele takich praw przysługujących ludziom, z których goryle czy szympansy mogłyby z powodzeniem korzystać (prawo do życia, swobodnego wyboru miejsca pobytu itd., itd.). Istnieje jednak wiele takich, z których, jak się wydaje, nie mogłyby czy nie potrafiły korzystać. Należy do nich np. prawo do wzięcia udziału w wyborach powszechnych czy prawo do wyznawania określonej religii. O ile mi również wiadomo, omawiana sugestia obejmuje tylko prawa, a nie dotyczy już obowiązków. Trudno wyobrazić sobie stawianie goryli czy szympansów przed sądem, wytaczanie procesów i skazywanie, np. na kary długoletniego więzienia. Bez wątpienia małpy człekokształtne są pod wieloma względami bardzo podobne do ludzi, nakładanie na nie ludzkich obowiązków byłoby jednak nie tylko absurdem, ale i bezmyślnym okrucieństwem.

Przyjrzeliśmy się ludziom (reprezentowanym przez Agnieszkę i Piotra), zjawiskom przyrody, artefaktom i zwierzętom. Pora na pytanie i filozoficzny problem. Pytanie nasze brzmi: Dlaczego ludzie miewają żale i pretensje tylko do ludzi, tylko na nich się obrażają i tylko ich (innych ludzi) są skłonni potępiać pod względem moralnym? Co takiego (zdaniem ludzi) posiadają ludzie, czego brak zjawiskom przyrody, artefaktom i zwierzętom? Krótka i bardzo filozoficzna odpowiedź na postawione pytania brzmi: Bo tylko ludzie, zdaniem ludzi, posiadają wo In ą wo lę! Pani Agnieszka miała żal i pretensje do pana Piotra, a w końcu może i obraziła się na niego dlatego, że sądziła (i sądzi), iż niestawienie się w określonym miejscu, w określonym czasie, z odpowiednią sumą pieniędzy było swobodnym wyborem pana Piotra. Gdyby zechciał przyjść, przyszedłby. Postanowił nie przyjść i nie przyszedł. Takiej możliwości, możliwości dokonania swobodnego wyboru i postępowania zgodnie z tym wyborem, nie mają ani zjawiska przyrody, ani artefakty, ani zwierzęta. Filozoficzny problem, zwany problemem wolnej woli polega zaś na tym, że przypisanie takiego daru ludziom, daru polegające- 
go na możliwości dokonywania swobodnych wyborów i postępowania zgodnie z nimi, wydaje się nie do pogodzenia (a w każdym razie bardzo trudne do pogodzenia) z innymi naszymi przeświadczeniami. Piszemy na razie bardzo ogólnie o przeświadczeniach dlatego, że problem wolnej woli ma dwie odmiany, a mianowicie wersję, którą w dalszym ciągu nazywać będziemy wersją teologiczną oraz wariant, który w dalszym ciągu nazywać będziemy wersją naturalistyczną. W pierwszym przypadku chodzi o przeświadczenia dotyczące Boga, w drugim ludzi i materialnej przyrody. Nim dokładniej scharakteryzujemy obie wersje, musimy wpierw spróbować lepiej określić dar zwany wolną wolę.

\section{A cóż to takiego wolna wola? (próba definicji)}

W trakcie prowadzenia zajęć ze studentami z problemu wolnej woli często na początku zajęć prosiłem słuchaczy o podanie własnej definicji. Najczęściej proponowane określenie wyglądało mniej więcej tak:

(01) Pewne $X$ (człowiek, robot, anioł...) posiada wolną wolę wtedy i tylko wtedy, gdy $X$ robi to, co chce robić.

Sądzimy, że powyższa propozycja jest dobrym punktem wyjścia. Chwyta ona - wydaje się - podstawową intuicję związane $z$ wolną wolą. A jest ona, jak sądzimy, mniej więcej następująca: Ja, Piotr, Agnieszka... i inni ludzie posiadamy wolną wolę dlatego, że możemy dokonywać wyborów i - wydaje się - nieustannie korzystamy z tej możliwości. Jeżeli zechcę podnieść do góry prawą rękę, to ją podnoszę; gdybym zechciał podnieść lewą, to podniósłbym lewą; jeśli zechcę, mogę powiedzieć: Ala ma kota, ale przecie równie dobrze (gdybym tak zechciał) mógłbym powiedzieć: Pies ma Alę itd., itd. Takich możliwości nie mają ani lodowce zsuwające się po zboczach gór, ani opady atmosferyczne, ani planety poruszające się po określonych orbitach, ani w ogóle jakiekolwiek wydarzenia lub czysto przyrodnicze procesy, procesów zachodzących w artefaktach (samochodach, pralkach automatycznych, komputerach itd.) nie wyłączając. Ludzie wydają się pod tym względem wyjątkowi. A co ze zwierzętami? Wszak i one, rzec można (pod warunkiem, że nie są w taki lub inny sposób więzione) robią, co chcą. W ostatniej uwadze jest coś na rzeczy i dlatego w dalszej części tego rozdziału postaramy się lepiej wyjaśnić, na czym, naszym zdaniem, polega różnica pomiędzy ludźmi a zwierzętami pod interesującym nas tutaj względem. Póki co, zajmijmy się innymi sprawami.

Otóż, formuła (01) jest (oczywiście) pod wieloma względami niejasna $\mathrm{i}$ - przyznajmy to od razu - w znacznej mierze taką pozostanie (pomimo naszych usilnych starań). Sądzimy zresztą, że nie ma na to rady. Rozważania dotyczące wolnej woli muszą się odwoływać do intuicji i pojęć, których nie można zupełnie 
ściśle zdefiniować. Nie znaczy to, że jesteśmy skazani na całkowity chaos. Wiele rzeczy można przedstawić w sposób precyzyjny, rozumienie wielu innych - ograniczyć, a jeszcze innych - ulepszyć. W każdym razie będziemy się starali.

Na początek zauważmy, że (01) jest na bakier z naturalizacją. W przyrodzie różne rzeczy wydarzają się lub zachodzą. Na robienie czy też działanie (terminów tych używać będziemy wymiennie) nie ma tam miejsca; tym mniej na robienie tego, co się chce. Wulkany, rzeki, planety... substancje chemiczne lub cząstki elementarne niczego nie robią ani nie działają. Jeżeli człowiek jest nieodłączną częścią przyrody, to nigdy nic nie robi ani nie działa. W znaturalizowanym opisie istot ludzkich nie ma miejsca na robienie. Jeżeli naturalizm jest prawdziwy, to wszystko, co ludzie rzekomo robią, w rzeczywistości zachodzi lub wydarza się, tak samo jak ruchy planet, wylewy rzek czy wybuchy wulkanów. Dziwne to, prawda?

Nie zajmujemy się tu jednak naturalizacją, tylko problemem wolnej woli. Powróćmy do naszej prowizorycznej definicji.

(01) Pewne $X$ (człowiek, robot, anioł...) posiada wolną wolę wtedy i tylko wtedy, gdy $X$ robi to, co chce robić.

Załóżmy teraz, że pewien $X$ twierdzi, że posiada wolną wolę. Pytanie, które się nasuwa, jest następujące. Czy nie można byłoby sprawdzić, czy mówi prawdę. Innymi słowy, czy nie można byłoby ustalić, czy definiens proponowanej definicji jest spełniony. W końcu o różnych ludziach w różnych sytuacjach zwykło się często mówić, że robią, co chcą. Ci, którzy posługują się tym zwrotem, nie używają go przecież na chybił trafił. Spróbujmy pójść tą drogą i przyjrzeć się, w jakich okolicznościach jest on używany. Wpierw jednak musimy wprowadzić kilka uściśleń.

Po pierwsze, jeżeli mówimy o działaniu lub robieniu czegoś, należy wspomnieć o środowisku. Jeżeli ktoś coś robi lub działa, to zawsze czyni to w jakimś środowisku. A w różnych środowiskach można robić bardzo różne rzeczy. Inne na pustyni, inne pod prysznicem, a jeszcze inne w składzie porcelany.

Po drugie, wyrażenie robi to, co chce robić, którym posłużyliśmy się w definiensie (01) jest niesłychanie potoczne i bardzo nieścisłe. Jeżeli dyskutujemy o wolnej woli ludzi (a nie np. aniołów czy bogów olimpijskich), to wiadomo, że mówiąc o robieniu tego, co się chce, ma się na myśli tylko pewien dość wąski zakres potencjalnych działań, w obrębie których możemy dokonywać wyboru. Nie powiedzielibyśmy, że pan X-iński nie posiada wolnej woli, bo chce przesunąć księżyc w prawą stronę, a ten się nie przesuwa itd., itd.

Ktoś mógłby powiedzieć, że można z tego dość łatwo wybrnąć. W końcu, jeżeli coś robimy, to niezależnie od środowiska musimy posłużyć się jakoś własnym ciałem - rękami, nogami, strunami głosowymi itd. Czy nie można byłoby zatem po prostu przyjąć, że fraza robi to, co chce robić odnosi się do ciała potencjalnego posiadacza wolnej woli i znaczy tyle, co: $w$ dowolny sposób steruje swym własnym ciałem. Propozycja taka może jednak budzić innego rodzaju wątpliwości. Po pierwsze, należałoby wyjaśnić, o jakie mianowicie sterowanie chodzi. Ludzie wykonują, jeśli zechcą (a przynajmniej takie jest dość powszechne przekonanie) dość skomplikowane operacje rękami czy nogami, ale nie są w stanie, nawet jeśli 
chcą (a przynajmniej takie jest dość powszechne przekonanie) unieść się w powietrze, przeniknąć przez ścianę lub zmniejszyć w ciągu sekund masę swego ciała. Po drugie, nawet jeśli uznalibyśmy, że „nie ma się co czepiać”, gdyż nawet bez definiowania wiadomo o jaką władzę nad ciałem chodzi, to w dalszym ciągu bylibyśmy w kłopocie. Istnieją ludzie częściowo lub całkowicie sparaliżowani, którzy częściowo lub całkowicie utracili władzę nad swoimi ciałami. Czy ludzie ci, wraz z postępem choroby, częściowo lub całkowicie utracili dar, zwany wolną wolą? Można się o to spierać, a niejeden teolog twierdziłby zapewne, że zachowali ten dar. Po trzecie wreszcie, nie chcielibyśmy wykluczać dualizmu za pomocą definicji. Chociaż w czasach szalejącego naturalizmu brzmi to jak bajka o smokach ziejących ogniem, to jednak, być może, istnieją istoty pozbawione materialnych ciał, a przy tym obdarzone wolną wolą. Sądzimy, że częściowym lekarstwem na wyłuszczone kłopoty byłaby mniej więcej następująca formuła:

(02) Pewne $X$ (człowiek, robot, anioł...) posiada wolną wolę wtedy i tylko wtedy, gdy X potrafiłby (byłby do tego zdolny, gdyby nadarzyła się taka możliwość) dokonywać wyborów w pewnym zbiorze (co najmniej dwóch różnych) możliwości.

Sądzę, że niezbędne są dodatkowe wyjaśnienia. Otóż, definiens (02) odwołuje się nie do tego, co ktoś robi, tylko do tego, co potrafiłby zrobić, gdyby sytuacja była odpowiednia i od tego uzależnia posiadanie wolnej woli. Tak więc pewien kompletnie sparaliżowany osobnik, niezdolny nawet do mrugania powiekami czy dawania znaków oczami (niezdolny do jakiegokolwiek komunikowania się ze światem w standardowy sposób), w dalszym ciągu mógłby posiadać wolną wolę. Przy takim ujęciu wolna wola byłaby typową własnością dyspozycyjną. Byłby to dar, który - o ile nie pojawiłyby się odpowiednie warunki - mógłby się nigdy nie ujawnić (tak, jak np. tłukliwość pewnego dzbana mogłaby się nigdy nie ujawnić). Takie określenie wolnej woli wydaje się jednak również niewłaściwe. Przy takim podejściu, o kimś, kto całe życie spędził w kapsule uniemożliwiającej jakiekolwiek ruchy należałoby powiedzieć, że miał wolną wolę, gdyż zachował dyspozycję do dokonywania wyborów (bo gdyby go stamtąd wypuszczono, to mógłby wybierać). Wolna wola to nie tylko określona dyspozycja, lecz także pewien zakres wolności Aby ktoś rzeczywiście posiadał wolną wolę, musiałyby być zatem spełnione, naszym zdaniem, dwa warunki. $Z$ jednej strony musiałby posiadać określoną dyspozycję, dar, moc itd. dokonywania wyborów, z drugiej - musiałby mieć możliwość korzystania z tego daru. Pierwszy z tych warunków nakłada określone wymagania na działającą osobę, drugi - na środowisko. Uwagi te prowadzą nas do kolejnego, ulepszonego określenia wolnej woli.

(03) Pewne $X$ (człowiek, robot, anioł...) posiada wolną wolę wtedy i tylko wtedy, gdy spełnione są dwa następujące warunki:

(A) X posiada dar (byłby do tego zdolny, gdyby nadarzyła się taka możliwość) dokonywania wyborów w pewnym zbiorze (co najmniej dwóch różnych) możliwości. 
(B) X działa (żyje, istnieje, przebywa) w świecie (środowisku), w którym istnieje możliwość dokonywania wyborów i X z niej korzysta.

Czytelnikom oswojonym z definiowaniem nasuwa się zapewne następująca uwaga. Czy nie można byłoby skrócić powyższej definicji, połączyć warunków (A) i (B) oraz napisać po prostu, że Pewne $X$ (człowiek, robot, anioł...) posiada wolną wolę wtedy i tylko wtedy, gdy $X$ dokonuje wyborów. Warunek ten wydaje się równoważny koniunkcji $(\mathbf{A})$ oraz $(B)$. W końcu ktoś, kto dokonuje wyborów, musi zarówno posiadać odpowiednią dyspozycję, jak i działać w środowisku, które umożliwia korzystanie z owej dyspozycji. W przypadku rozważań dotyczących wolnej woli z pewnych względów dobrze jest mieć warunki te wyrażone osobno. Wyrażone łącznie, jednym zdaniem, tracą swą wyrazistość, a w niektórych kontekstach przestajemy zauważać, że mamy do czynienia z dwoma odrębnymi wymaganiami: jednym wyrażonym pod adresem środowiska, drugim - pod adresem podmiotu. W przyszłości będziemy się do nich często odwoływać.

Po tym, jak wyjaśniliśmy nasze rozumienie wolnej woli, możemy przystąpić do sprecyzowania filozoficznego problemu, kolejno w jego wersji teologicznej i naturalistycznej. Przedtem jednak chcielibyśmy poczynić dwie dość ogólne uwagi. Ułatwią one dalszą lekturę tego rozdziału.

Pierwsza uwaga jest następująca. Współczesnych badaczy, zajmujących się wolną wolą, zwykło się dzielić na kompatybilistów oraz inkompatybilistów. $\mathrm{Ci}$ pierwsi sądzą, że wolną wolę można pogodzić z determinizmem, ci drudzy - że nie; ci pierwsi rozumieją wolną wolę jako brak ograniczeń (takich jak więzienie, kraty, łańcuchy itd.), ci drudzy sądzą, że trzeba czegoś znacznie więcej. Istota obdarzona wolną wolą musi posiadać rzeczywiste siły sprawcze; być czymś w rodzaju pierwszego poruszyciela. Nasze określenie wolnej woli umiejscawia nas po stronie inkompatybilistów. Jednym z głównych problemów inkompatybilizmu (w naturalistycznym wariancie problemu) jest wyjaśnienie, jak takie podmiotowe przyczynowanie jest możliwe. W przyszłości (ale dopiero pod koniec rozdziału) poruszymy ten temat.

Druga uwaga jest taka, że gdy rozważamy wersję teologiczną problemu wolnej woli, to stosunkowo łatwo można sobie wyobrazić (zaakceptować czy też przyjąć), że warunek (A) naszej definicji mógłby być spełniony, natomiast są trudności z wyobrażeniem sobie, że warunek (B) również mógłby być spełniony. W przypadku naturalistycznej wersji problemu wolnej woli jest na odwrót. Warunek (B) wydaje się do zaakceptowania, natomiast nie sposób sobie wyobrazić sytuację, w której również warunek (A) byłby spełniony. 


\section{Wersja teologiczna problemu wolnej woli}

\subsection{Istota problemu}

Wersja teologiczna problemu polega na tym, że dar zwany wolną wolą wydaje się nie do pogodzenia z istnieniem istoty, która jest jednocześnie wszechmocna, nieskończenie doskonała, ws z e ch wi edzą c a i która, na dodatek, stworzyła świat. Istotę taką w dalszym ciągu będziemy określali tradycyjnym mianem Bóg. Otóż, można utrzymywać, że istnieje bezpośrednia sprzeczność pomiędzy Bożą wszechwiedzą a darem zwanym wolną wolą. Jeżeli Bóg jest wszechwiedzący, to zna przyszłość. Jeżeli zna przyszłość, to zna (między innymi) wszystkie przyszłe zachowania i wszystkie przyszłe myśli (postanowień i wyborów nie wyłączając) wszystkich ludzi. A skoro tak, to cała przyszłość, zarówno ta fizyczna, jak i mentalna, jest zdeterminowana przez Bożą przedwiedzę. A skoro przyszłość jest zdeterminowana, to ludzie są pozbawieni możliwości dokonywania swobodnych wyborów. A skoro są pozbawieni takiej możliwości, to warunek (B) definiensa naszej definicji nie jest spełniony i, tym samym, ludzie nie posiadają wolnej woli!

Czy zatem trzeba wybierać pomiędzy Bożą wszechwiedzą a ludzką wolną wolą? Czy w żaden sposób nie można pogodzić jednego z drugim? Sądzimy, że jest to możliwe. Wpierw przedstawimy takie próby i sugestie, pochodzące od św. Augustyna i Boecjusza, a następnie zaproponujemy coś własnego.

Nim zakończymy ten paragraf, powróćmy na moment do przykładu z panią Agnieszką i panem Piotrem i załóżmy, że zarówno pani Agnieszka, jak i pan Piotr są ludźmi głęboko religijnymi i oboje mocno wierzą w istnienie wszechwiedzącego Boga. Załóżmy dalej, że pani Agnieszka spotyka pana Piotra w środę i żąda wyjaśnień dotyczących niewywiązania się z obietnicy oddania pieniędzy we wtorek. A teraz wyobraźmy sobie, że wyjaśnienia pana Piotra wyglądają mniej więcej tak: Droga Agnieszko, jako osoba głęboko religijna zdajesz sobie zapewne sprawę z tego, że oprócz ludzi istnieje jeszcze wszechwiedzący Bóg. W chwili, gdy obiecywałem ci zwrot pieniędzy w najbliższy wtorek Istota ta (tzn. Bóg) już wiedziała (chociaż ja tego jeszcze nie wiedziałem i miałem szczery zamiar wywiązać się z obietnicy), że w końcu jednak postanowię nie oddawać ci pieniędzy. Wobec Bożej przedwiedzy byłem całkowicie bezradny, nie miałem wyboru i musiałem sprzeniewierzyć się danemu wcześniej słowu. Chyba to oczywiste! Nie rozumiem więc, skąd te pretensje i żale. Jeśli już chcesz mieć pretensje i koniecznie na kogoś się obrazić, to obraź się na Bożą przedwiedzę. Jako ludzie religijni wiemy jednak, że byłoby to straszliwe bluźnierstwo, którego popełnienie stanowczo odradzam.

Wypowiedź pana Piotra, którą zakończyliśmy poprzedni akapit sprawia wrażenie filozoficzno-religijnego żartu. Ludzie tak się nie tłumaczą. Czy to znaczy, że nie traktują poważnie swoich religijnych przeświadczeń? Niekoniecznie. Teolog posiadający filozoficzne wykształcenie potrafiłby zapewne udzielić bardziej sto- 
sownych wyjaśnień. Byłoby jednak jeszcze lepiej, gdyby udało się znaleźć takie rozwiązanie, które pokazałoby, w jaki sposób można pogodzić Bożą wszechwiedzę z pełną odpowiedzialnością pana Piotra, czyli, innymi słowy, gdyby udało się znaleźć rozwiązanie problemu wolnej woli w jego teologicznej wersji. Niniejszym chcielibyśmy przedstawić pewną propozycję rozwiązania tego problemu. Nie jesteśmy aż tak pyszni, aby sądzić, że udało nam się definitywnie rozwiązać ten problem. Sądzimy jednak (też nieskromnie), że udało nam się spojrzeć na niego w dość szczególny sposób.

Pomysł, który przedstawimy, zrodził się w wyniku lektury fragmentów niektórych prac św. Augustyna i Boecjusza. Zacytuję te fragmenty oraz wyjaśnię, jak je rozumiem i w jaki sposób mnie zainspirowały.

\subsection{Pomysły św. Augustyna i Boecjusza}

W jednym z dialogów filozoficznych św. Augustyn (Augustyn 1953), odpierając obiekcje niejakiego Ewodiusza, zauważa w pewnym momencie: „Podobnie jak ty nie powodujesz przeszłych zdarzeń przez to, że je pamiętasz, tak samo Bóg nie wywiera przymusu na przyszłe wypadki przez to, że je zna" (Augustyn 1953, s. 176). W zacytowanym fragmencie zawarta jest, wydaje się, sugestia, że stosunek poznawczy Boga do przyszłości jest mniej więcej taki, jak ludzi do przeszłości. Z punktu widzenia Boga, wszystko jest przeszłością. Idea ta wyrażona jest explicite w De diversis quaestionibus 17, gdzie filozof ten wypowiada pogląd następujący:

Przeszłości ani przyszłości nie ma, istnieje aktualnie tylko teraźniejszość, przeszłości i przyszłości brakuje, w Bogu zaś nie ma braku, a zatem u Niego jest tylko teraźniejszość. (Augustyn 1953: 176)

Bardzo podobną ideę rozwija Boecjusz. Oto dwa fragmenty z Pocieszenia, mające wyjaśniać naturę Boskiej przedwiedzy:

Zatem jeżeli chcesz rozważyć Jego przedwiedzę, która osobno poznaje wszystkie rzeczy, to słuszniej zrobisz, jeśli uznasz, że nie jest ona przewiedzą w znaczeniu wiedzy o przyszłości, ale w sensie wiedzy o nigdy nie ustającej teraźniejszości (Boecjusz 2006, ks. V: 127)

Lecz jeśli stosowne jest porównanie obecności Boskiej i ludzkiej, to jak wy, ludzie widzicie pewne rzeczy w waszej czasowej obecności, tak Bóg widzi wszystkie rzeczy w jego obecności wiecznej [...]. Podobnie jak ty, kiedy widzisz, w jednym i tym samym czasie, człowieka, który idzie po ziemi, i słońce, które wschodzi na niebie.... (Boecjusz 2006, ks. V: 127)

Koncepcję Augustyna - Boecjusza można scharakteryzować tak: Z Boskiego punktu widzenia nie ma różnicy pomiędzy przeszłością, teraźniejszością i przyszłością. Rozróżnienia te mają sens tylko dla ludzi i tylko z ludzkiego punktu widzenia. Bóg, Super-Obserwator w Swej wiecznej teraźniejszości zna (lub widzi) równie dobrze to, co dla ludzi przedstawia się jako przeszłość, teraźniejszość i przyszłość. 
W cytowanych fragmentach Pocieszenia odnaleźć można jeszcze jeden bardzo ciekawy trop. Autor, starając się nam przybliżyć Boski punkt widzenia, przyrównuje Boskie widzenie oddalonych w czasie wydarzeń do ludzkiego widzenia dwóch różnych wydarzeń zachodzących dla ludzi w tym samym czasie, ale w różnych miejscach (przechadzający się po ziemi człowiek i wschodzące słońce). Być może należałoby Boecjusza uznać za prekursora pomysłu, że czas jest czwartym wymiarem. (O ile wiemy, autorstwo jest przypisywane D'Alambertowi).

Różnicę pomiędzy ludźmi a Bogiem w interesującej nas kwestii można byłoby opisać jakoś tak. Dla ludzi przeszłość, teraźniejszość i przyszłość - to rzeczy bardzo różne, a różnice pomiędzy nimi - bardzo ważne. Ludzie żyją w (ciągle stającej się) teraźniejszości i teraźniejszością. Przeszłość i przyszłość nie są bezpośrednio obecne. W pewnym sensie w ogóle nie istnieją. Przeszłości już nie ma, a przyszłości jeszcze nie ma i być może nigdy nie będzie. Dla Boga różnice te nie mają żadnego znaczenia. Z Boskiego punktu widzenia, wszystkie zdarzenia obecne są i dane w ten sam sposób, w wiecznej teraźniejszości, która jest czymś zasadniczo innym niż teraźniejszość ludzka.

Zajmijmy się teraz wolną wolą. W jaki sposób św. Augustyn godzi Bożą znajomość przyszłości z ludzką wolną wolą? Przypomnijmy jeszcze raz kluczowy fragment dialogu: „Podobnie jak ty nie powodujesz przeszłych zdarzeń przez to, że je pamiętasz, tak samo Bóg nie wywiera przymusu na przyszłe wypadki przez to, że je zna" (s. 176). Stanowisko św. Augustyna jest takie: Bóg rzeczywiście zna przyszłość, podobnie jak wielu ludzi zna różne fragmenty przeszłości, sprawcą różnych przyszłych uczynków będą jednak konkretni ludzie, a nie Bóg, podobnie jak wiele pamiętanych zdarzeń nie jest powodowana przez tych, którzy je pamiętają. Sama wiedza czy też przedwiedza (nawet, jeśli pewna) niczego jeszcze nie powoduje.

Aby lepiej zrozumieć myśl, która się za tym kryje, spróbujmy postawić się w sytuacji Pana Boga. Oczywiście nie jesteśmy w stanie znać (czy też pamiętać) przyszłości. Namiastkę takiego stanu poznawczego moglibyśmy osiągnąć (tak się przynajmniej autorowi tej książki wydaje), gdybyśmy przenieśli się w czasie w przeszłość. Wyobraźmy sobie wobec tego, że podróże w czasie są możliwe (literatura i kinematografia tak dalece oswoiły nas z takimi wycieczkami, że nie wydają się one niczym nadzwyczajnym). Załóżmy dalej, że korzystając z tej możliwości udajemy się odpowiednim wehikułem w przeszłość, do roku 1912. Ponieważ nasza wiedza historyczna dotycząca wieku XX i początków XXI jest niedoskonała i zawiera liczne luki, zabieramy ze sobą odpowiednią literaturę zapisaną na dysku poręcznego laptopa. Teraz, gdy wysiedliśmy z naszego wehikułu w roku 1912, nasza sytuacja poznawcza w odniesieniu do lat 1912-2012 jest zbliżona do sytuacji poznawczej Boga w odniesieniu do przyszłości, czyli do lat 2012-2112. Lata 1912-2012 - to dla nas teraz przyszłość, którą znamy (lub pamiętamy). Wiemy, co się wydarzy i co kto zrobi. W szczególności znamy przyszłe postępki wielkich zbrodniarzy (w razie, gdy pamięć nas zawodzi, korzystamy z pomocy laptopa). Wiemy, co i kiedy zrobi Hitler, Stalin, Pol Pot.... Nasza wiedza nie czyni nas jednak odpowiedzialnymi za czyny tych ludzi. Bylibyśmy niezmiernie zdziwieni, gdyby próbowano obwinić nas (lub choćby współobwinić) za przyszłe czyny Hitlera, Stalina, Pol Pota itd. tylko dlatego, że je znamy. Wiedza (również ta dotycząca przyszłości) i sprawstwo - to dwie 
zupełnie różne rzeczy. Wiedza, sama przez się, nie ma mocy sprawczej. Tak więc my tylko wiemy co oni zrobią, ale oni to zrobią i to oni będą prawdziwymi grzesznikami i rzeczą ze wszech miar słuszną byłoby sprawiedliwie ich ukarać. Gdybyśmy chcieli spojrzeć na stanowisko św. Augustyna przez pryzmat naszej definicji, to powiedzielibyśmy, że według tego filozofa sprawy mają się tak, że warunek (A) jest spełniony, a warunek (B) nie jest spełniony. Innymi słowy, według św. Augustyna, ludzie, choć nie mają wyboru (gdyż przyszłość jest określona z dokładnością do najdrobniejszych szczegółów przez Bożą przedwiedzę), i tak są rzeczywistymi sprawcami. Święty Augustyn stara się pokazać, że sprawstwo i możliwość dokonywania wyborów - to jednak dwie różne rzeczy. Jeżeli nawet ma on rację, to i tak sądzimy, że jego argument, w rozpatrywanym teologicznym kontekście, chybił celu. Bóg nie jest po prostu Super-Jasnowidzem, który zna przyszłość. Bóg przyszłość stworzył!

Podróże w czasie zawsze kojarzyły nam się z kinematografią i to bynajmniej nie z powodu filmów z gatunku science fiction. Otóż, abym mógł udać się w przyszłość lub przeszłość, to one muszą istnieć $\mathrm{i}$ ich status ontologiczny musi być taki, jak teraźniejszości. Weźmy pod uwagę jakiś konkretny film fabularny, w którym chronologia przedstawianych zdarzeń nie budzi żadnych wątpliwości. Dla ustalenia uwagi niech będzie to Pan Tadeusz w reżyserii Andrzeja Wajdy. Załóżmy, że kręcenie filmu zostało właśnie ukończone i że jest on utrwalony na tradycyjnym nośniku, czyli na filmowej kliszy. Dla osoby biorącej do ręki ten przedmiot (tzn. tę zwiniętą w rolkę filmową kliszę) cała długa historia tam utrwalona z całkiem określoną kolejnością zdarzeń jest dana w teraźniejszości. Rozwińmy teraz tę taśmę na jakiejś płaskiej powierzchni. Możemy wodzić wzrokiem po kliszy, a nawet dotykać ją palcem w różnych miejscach i wszędzie jest ona (z naszego punktu widzenia) taka sama. Załóżmy teraz, że wyświetlamy ten film. Możemy przewinąć go do przodu albo do tyłu i zatrzymać się $w$ dowolnym miejscu przedstawianej historii. Czyż nie przypomina to podróży w czasie? Oczywiście przedstawiany świat nie jest rzeczywisty, a my nie jesteśmy jedną z jego postaci. Spróbujmy jednak iść tym tropem i trzymajmy się kinematograficznej analogii. Załóżmy, że Bóg stworzył świat w całości mniej więcej $w$ takim sensie, $w$ jakim reżyser tworzy film w całości. Załóżmy ponadto, że wszystkie „wyświetlane” obiekty - drzewa, kamienie, rzeki, planety, gwiazdy, galaktyki... są w pełni realne, cokolwiek miałoby to znaczyć. Wyświetlani ludzie widzą, słyszą... myślą, kochają i nienawidzą, a ukłuci wyświetlaną szpilką czują całkiem prawdziwy ból. Innymi słowy, świat, który staram się opisać, niczym się nie różni od naszego świata, w którym żyjemy. Załóżmy, że Pan Bóg potrafi kręcić takie filmy i że świat, w którym żyjemy, jest po prostu takim Boskim filmem.

Poszukiwanie analogii pomiędzy światem a filmem i przyrównywanie Boga do reżysera może się jednak wydać niedopuszczalnym nadużyciem. Porównywanie świata i Boga do czegokolwiek innego byłoby jednak także nadużyciem, a chcielibyśmy jakoś pomóc wyobraźni. Leibnitz, argumentując, że Bóg stworzył najlepszy z możliwych światów, tworząc możliwie największą ilość dobra kosztem możliwie najmniejszej ilości zła, pomaga wyobraźni swych czytelników, porównując świat do gigantycznego obrazu (Leibniz 1969). Podobnymi porównaniami posługuje się św. Augustyn. Sądzimy, że gdyby filozofowie ci żyli w czasach nam współczesnych, sięgnęliby po porównanie z ruchomymi obrazami. 
Próbując lepiej zrozumieć argument św. Augustyna i lepiej wyobrazić sobie sytuację poznawczą Pana Boga, wybraliśmy się wehikułem w przeszłość. Podróże w czasie z kolei przywiodły nam na myśl kinematografię, nakręcone filmy i reżyserów, a to z kolei uświadomiło różnicę zachodzącą pomiędzy Bogiem a Jasnowidzem. Gdyby Bóg był po prostu Super-Jasnowidzem, to argument św. Augustyna byłby trafny. Bóg jednak nie tylko zna przyszłość, lecz także ją (zupełnie jak reżyser nakręconego filmu) stworzył.

Załóżmy, że Boski film jest stworzony wraz z całą przyszłością. To, co dla wyświetlanych postaci jest niewiadomą i oczekiwaną przyszłością, dla Boga, tak jak dla producenta filmu, jest przeszłością. Przy takiej koncepcji Bóg nie jest Super-Jasnowidzem, który bezbłędnie przewiduje to, co dopiero ma się stać. Przyszłość już istnieje, a ludzie tylko jej nie znają. Nasuwa się w związku z tym pytanie: Jak, przy takiej koncepcji przyszłości, można bronić realności wolnej woli? Otóż, naszym zdaniem, nie można. W świetle takiej koncepcji ludzie nie mają możliwości dokonywania wyborów, ale również nie są sprawcami. Jedynym rzeczywistym sprawcą jest wówczas Bóg. Ani warunek (A), ani warunek (B) naszej definicji nie są spełnione. Sprawstwo i wolna wola ludzi jest sprawstwem i wolną wolą na niby.

\subsection{Inne spojrzenie}

Pora na nasz pomysł. Naszym zdaniem, rozwiązanie problemu wolnej woli w jego wersji teologicznej polega na pogodzeniu ze sobą trzech rzeczy, a mianowicie: ludzkiej wolnej woli, Bożej wszechwiedzy i tego, że Bóg stworzył świat w całości. Innymi słowy, chodzi o wyjaśnienie, w jaki sposób trzy następujące warunki mogłyby zostać jednocześnie spełnione:

(1) Bóg stworzył świat w całości

(2) Bóg jest wszechwiedzący

(3) Ludzie posiadają wolną wolę

Powyższe warunki z pewnością nie są całkowicie jasne i mogą być różnie rozumiane. Sądzę, że nie ma na to rady i tak musi pozostać. Wszelkiego rodzaju warunki, formułowane z użyciem. pojęcia Boga, wszechwiedzy i wolnej woli nigdy nie będą zupełnie jasne i jednoznaczne. Mamy nadzieję, że w dalszym ciągu ich rozumienie uda się nieco ograniczyć.

Przede wszystkim zauważmy, że utrudniliśmy sobie sytuację. Do warunku (2), który sam przez się wydaje się sprzeczny z wolną wolą, dodaliśmy warunek (1), który (wyraźmy się niezręcznie, ale sugestywnie) wydaje się jeszcze bardziej sprzeczny z wolną wolą i dlatego umieściliśmy go na pierwszym miejscu. Warunek (1) chcę rozumieć w taki sposób, jak starałem się to wyjaśnić. Powtórzmy to wyjaśnienie, zestawiając Boską twórczość z ludzką. Jeżeli ludzie wytwarzają jakiś obiekt, np. stół, samochód, komputer..., cokolwiek zresztą, to nie wytwarzają tego obiektu w całości w tym sensie, że nie wytwarzają jego przyszłości. 
Jeżeli nawet przyszłość pewnego obiektu wytworzonego przez ludzi byłaby zdeterminowana, to w każdym razie nie byłaby fabrycznie wytworzona. Świat natomiast został przez Boga stworzony w całości, tzn. wraz z całą przyszłością. Świat byłby stworzony w całości w takim sensie, w jakim film jest nakręcony w całości. Bezbłędne przewidywanie musi się spełnić, ale stworzona przyszłość już jest spełniona i dlatego warunek (1) wydaje się trudniejszy do pogodzenia z wolną wolą niż warunek (2).

Czy wobec tego warunek (1) nie pociąga za sobą (2)? W przypadku ludzkich twórców i zwykłych dzieł z pewnością autorstwo nie oznacza pełniej znajomości dzieła. Jak jest w przypadku Boga i świata, tego nie wiemy i dlatego (na wszelki wypadek) zamieściliśmy zarówno (1), jak i (2).

Zauważyliśmy w jednym z poprzednich akapitów, że warunki (1), (2) i (3) nie są całkowicie jasne i mogą być różnie rozumiane. Uwaga ta z pewnością jest też w jakiejś mierze prawdziwa w odniesieniu do rozwiązania, które proponujemy.

\subsection{Propozycja rozwiązania problemu wolnej woli w wersji teologicznej}

Święty Augustyn i Leibnitz porównywali świat do obrazu a Boga do malarza. Uznaliśmy, że intencje tych filozofów lepiej oddawałoby porównanie świata do (już nakręconego) filmu, a Boga do reżysera i że posłużyliby się oni takim właśnie porównaniem, gdyby wiedzieli, tyle co my, o kinematografii.

Metafory obrazu i filmu pobudzają wyobraźnię i ułatwiają zrozumienie, na czym mogłoby polegać stworzenie świata w całości (tzn. wraz z całą przyszłością) oraz Boska wszechwiedza. Ich słabą stroną jest to, że nie ma w nich miejsca na wolną wolę. Jeżeli porównamy świat do nakręconego filmu, a ludzi do wyświetlanych postaci, to wolna wola takich wyświetlanych postaci jest wolną wolą na niby; na niby jest również ich sprawstwo. Jedynym i prawdziwym sprawcą jest wówczas autor filmu. Czy jednak możliwa jest sytuacja, w której warunki (1) i (2) są spełnione, a ludzie są, wyraźmy się górnolotnie, w ostatecznym metafizycznym rachunku rzeczywistymi sprawcami, rzeczywiście dokonują wyborów i naprawdę posiadają wolną wolę? Sądzimy, że tak. Rozwiązanie, które proponujemy jest niesłychanie proste. Jego prostota może się wydać podejrzana. Ale cóż na to począć? Oto ono.

Porównajmy tym razem świat do dyskietki, na której jest zapisana gra komputerowa. Załóżmy dalej, że gra zawiera bardzo dużo alternatywnych możliwości. Schemat gry przypomina olbrzymie drzewo o ogromnej ilości rozgałęziających się konarów. Są to różne drogi, którymi mogą podążać potencjalni gracze. Dyskietka wraz z zapisaną na niej grą jest wyprodukowana (stworzona) w całości, a producent (stwórca) dyskietki wie o niej wszystko, w szczególności zna dokładnie całe drzewo gry. Warunki (1) i (2) są więc spełnione. Przejdźmy do wolnej woli i postaci, które miałyby ją posiadać. Otóż załóżmy, że postacie, które zwykliśmy nazywać wirtualnymi i których zachowaniami w zwykłej grze kieruje 
gracz, są w tej akurat grze rzeczywiste, posiadają autonomię bytową i samodzielnie wybierają drogę, którą podążają. Droga ta nieustannie się rozgałęzia. To, którą akurat ścieżką podąży dana postać, zależy tylko od niej i to ona (ta postać), a nie producent jest rzeczywistym sprawcą wyboru. W ten sposób zarówno warunek (A), jak i (B) definiensa naszej definicji są jednocześnie spełnione - środowisko stwarza możliwość wyboru, a gracze są wyposażeni w moc ich dokonywania. Producent, chociaż jest twórcą dyskietki i wie o niej wszystko, nie wie, jakich wyborów dokonają poszczególne postaci. Jego znajomość dyskietki, jego przedwiedza nie determinuje zachowań tych postaci. Postaci te naprawdę posiadają wolną wolę!

Myślmy o Bogu i stworzeniu świata w kategoriach producenta dyskietki z grą komputerową, a o ludziach jako o wirtualnych postaciach, obdarzonych możliwością dokonywania prawdziwych wyborów, a nietrudno będzie nam sobie wyobrazić sytuację, w której warunki (1), (2 ) i (3) byłyby wszystkie jednocześnie spełnione.

Przejdźmy do zastrzeżeń i wątpliwości, które wzbudza przedstawiony pomysł. Najpoważniejszym zarzutem, wydaje się, byłby następujący. Przecież w proponowanym modelu Bóg nie wiedziałby, co poszczególni ludzie zrobią! Czy w tej sytuacji można twierdzić, że Bóg zna przyszłość? I jakże można twierdzić w takim razie, że Bóg jest wszechwiedzący?! Na powyższą obiekcję odpowiadamy, że Bóg jest nawet w większym stopniu wszechwiedzący niż w przypadku modelu kinematograficznego, albowiem, gdyby stworzony świat przypominał film, Bóg znałby tylko jedną przyszłość, a w proponowanym rozwiązaniu zna wszelkie możliwe przyszłości! Wytłumaczmy się dokładniej w następnym akapicie.

Przyjrzyjmy się jeszcze raz proponowanemu rozwiązaniu. Po pierwsze, świat jest stworzony w całości, wraz z wszelkimi możliwymi przyszłościami. Również tymi przyszłościami, którymi nigdy nie będzie podążała żadna istota obdarzona wolną wolą. To, że świat jest stworzony w całości, chcemy rozumieć możliwie najbardziej dosłownie. W przypadku modelu filmowego analogia była czytelna. Świat był stworzony w całości w takim samym sensie, w jakim film jest nakręcony $w$ całości. Tym razem chcemy to rozumieć bardzo podobnie. Świat jest stworzony w całości w takim samym sensie, w jakim dyskietka z wytrawionym na niej drzewem gry jest stworzona w całości. Wszechwiedza Boga w przypadku modelu filmowego polegała na tym, że wie On wszystko o nakręconym filmie. W przypadku gry, zupełnie analogicznie, wszechwiedza Boga polega na tym, że wie On wszystko o wytworzonej (stworzonej przez Siebie) dyskietce z wytrawionym nas niej drzewem gry. Wszechwiedza polega na kompletnej (absolutnej, pełnej) znajomości stworzonego świata.

Czy jednak ludzkie czyny, wszystkie czyny wszystkich ludzi, nie są integralną częścią stworzonego świata? Czy zatem może być tak, że świat jest stworzony w całości, Bóg wie o nim wszystko, a pomimo to nie wie, co zrobią istoty obdarzone wolną wolą? Sądzę, że jest to możliwe i postaram się wytłumaczyć, jak sobie to wyobrażam. Przez cały czas będziemy pomagać wyobraźni, odwołując się do porównania z grą komputerową. Otóż, świat jest stworzony w całości, z wszelki- 
mi możliwymi przyszłościami, w takim sensie, w jakim dyskietka z wytrawionym w niej drzewem gry jest wytworzona w całości. Wyakcentujmy pewną analogię, która wydaje się ważna. Otóż, w przypadku dyskietki z wytrawionym na niej drzewem gry, mogą istnieć takie odgałęzienia (możliwe przyszłości), które nigdy nie zostaną zaktualizowane przez żadnego gracza. Odgałęzienia te są jednak równie realne i równie rzeczywiste jak te, które są lub będą aktualizowane. Podobnie wyobrażam to sobie w przypadku świata. Stworzonych jest wiele różnych przyszłości. Te, które nigdy nie zostaną zaktualizowane, są równie rzeczywiste i realne jak ta, która jest aktualizowana. Tak jak w przypadku dyskietki.

Załóżmy, że pewien ludzki gracz gra w pewną grę komputerową, wciela się np. w postać Zygfryda Smokobójcy i aktualizuje jedną z wielu alternatywnych możliwości. Droga, którą kroczy, istnieje na dyskietce i dzięki dyskietce, to samo dotyczy Zygfryda Smokobójcy. Jest on, jak się powiada, postacią wirtualną, został wytworzony wraz z dyskietką i wszystkie jego własności, użyjmy modnego pojęcia, superweniują na własnościach dyskietki. Ludzki gracz, wcielający się w postać Zygfryda Smokobójcy, istnieje jednak (oczywiście) poza dyskietką i w żaden sposób nie należy do stworzonego na dyskietce świata. Analogia pomiędzy dyskietką z wytrawionym drzewem gry a światem stworzonym przez Boga załamuje się. Aby uratować naszą koncepcję, musimy wykonać pewien manewr, a mianowicie musimy się pozbyć ludzkiego gracza. Jego rolę i wszystkie jego uprawnienia musi przejąć sam Zygfryd Smokobójca i to on będzie teraz wybierał (rzeczywiście wybierał!) nieustannie jedną spośród wielu alternatywnych dróg i będzie posiadaczem wolnej woli. Powtórzmy jeszcze raz. Wszystkie własności Zygfryda Smokobójcy superweniują na fizycznych własnościach dyskietki, ale wybory, których on dokonuje nie są już określone poprzez fizyczne własności dyskietki. Co się tyczy wyborów, to sam Zygfryd Smokobójca jest ich pierwszą przyczyną, „nieruchomym poruszycielem”.

Jak to możliwe, ktoś mógłby zapytać. Odpowiadamy, że zupełnie tak samo jak wówczas, gdy ludzki gracz wciela się w Zygfryda Smokobójcę. Wszystkie własności Zygfryda Smokobójcy superweniują na fizycznych własnościach dyskietki, ale wybory, których on dokonuje już nie, bo dokonuje ich ludzki gracz, który jest spoza dyskietki i którego własności, rzecz jasna, nie superweniują na fizycznych własnościach dyskietki.

\subsubsection{Zabawa w Pana Boga}

Spójrzmy teraz na to wszystko w nowy sposób. W uzyskaniu nowego spojrzenia pomoże nam eksperyment myślowy. Polega on na tym, że będziemy próbowali stworzyć grę, w której niektóre wirtualne postacie byłyby obdarzone wolną wolą. Dodajmy, wolną wolą w sensie zaproponowanej przez nas definicji. Innymi słowy, gra musi być taka, że warunki (A) i (B), występujące w definiensie naszej definicji, są spełnione. Gra będzie w całości utrwalona na odpowiedniej dyskietce. Tworząc grę, będziemy w zasadzie zdani na siebie, ale od czasu do czasu będziemy korzystać z pomocy Pana Boga. Załóżmy więc, że zaplanowa- 
liśmy grę z olbrzymią liczbą rozgałęzień, a następnie urzeczywistniliśmy nasz plan w fizycznym materiale. (Podobieństwo jest ułomne, gdyż nie dokonaliśmy tego za sprawą zwykłego Niech się tak stanie, ale wystarczające dla naszych celów). „Świat”, który stworzyliśmy, jest, co oczywiste, stworzony w całości i pod postacią dyskietki spoczywa na półce. Przyjmijmy, że jest to jedyna taka dyskietka. Załóżmy, że jedyną postacią stworzonego przez nas mini-świata jest Zygfryd Smokobójca. Poza tym w grze pojawiają się tylko „czysto fizyczne” obiekty. Dopóki dyskietka leży spokojnie na półce, nasz mini-świat jest całkowicie uśpiony (tak jak gra, w którą nikt nie gra lub film, który nie jest wyświetlany). Załóżmy, że odpalamy grę i gra się zaczyna. Wszystko jest tak, jak w normalnej grze, z tym że Zygfryd Smokobójca widzi, słyszy..., a ukłuty wirtualną szpilką czuje prawdziwy ból. Jest to możliwe dzięki temu, że Zygfryd jest tylko wirtualną powłok, pod którą skrywa się ludzki gracz. To on (ten ludzki gracz) widzi, słyszy... i podejmuje decyzje. Jest duszą Zygfryda. Decyzje, które podejmuje Zygfryd nie zależą od własności stworzonego przez nas świata (fizycznych własności dyskietki), dlatego że są decyzjami człowieka, dla którego Zygfryd jest tylko powłoką i który ani nie należy, rzecz jasna, do dyskietki, ani nie jest jej częścią. Nim przejdziemy dalej, zwróćmy uwagę na okoliczność, która jest kluczowa dla bronionej przez nas koncepcji. Otóż, Zygfryd Smokobójca całkowicie należy do dyskietkowego świata. Poruszając się po nim, ani nie gwałci, ani nie narusza żadnych praw tego świata. Wyborów jednak - w tych miejscach, gdzie pojawia się możliwość dokonania wyboru - dokonuje ludzki gracz, pochodzący spoza tego świata. Ktoś mający poznawczy dostęp tylko do dyskietki, nie przewidzi tych wyborów. Dyskietkowy przyrodnik musiałby uznać swój świat za indeterministyczny. Wybory pochodzą z zewnątrz. Ich pierwszą przyczyną, nieporuszonym poruszycielem, jest ludzki gracz.

Do czego jest nam jednak potrzebny Pan Bóg? Otóż, Pan Bóg jest nam potrzebny, po raz pierwszy i ostatni, do tego, żeby tchnął w Zygfryda taką właśnie duszę, ale bez udziału ludzkiego gracza. (Być może pomoc Pana Boga wcale nie jest potrzebna. Istnieją takie postaci funkcjonalizmu, które dopuszczają możliwość tworzenia takich gier bez żadnych nadprzyrodzonych ingerencji.) Tytułem dygresji zauważmy, że gdyby taka właśnie gra została stworzona, to "zstąpienie" na dyskietkę przez ludzkiego gracza nie byłoby już niczym trudnym i nie wymagałoby żadnej nadprzyrodzonej pomocy. Zupełnie tak, jak prawdziwy człowiek. Gra ta ma jeszcze jedną osobliwość. A mianowicie, Zygfryd nie jest tylko jakąś wirtualną powłoką, którą posługuje się ludzki gracz, ale to on jest prawdziwym i jedynym graczem. Sprawcą wyborów i posiadaczem wolnej woli. Ludzie nie umieją tworzyć takich postaci i dlatego musimy skorzystać z pomocy Pana Boga.

W tym miejscu kończymy pierwszą część rozważań poświęconych wolnej woli, część teologiczną. 


\section{Wersja naturalistyczna problemu wolnej woli}

\subsection{Istota problemu}

Nie ma wszechwiedzącego Boga, co za ulga, ludzie wreszcie mogą robić to, co chcą - mógłby pomyśleć „raczkujący naturalista”. W rzeczy samej, główna przeszkoda blokująca ludzką wolną wolę w wersji teologicznej, a mianowicie Boża przedwiedza, jest nieobecna w wersji naturalistycznej. Nie znaczy to wcale, że perspektywy posiadania przez ludzi wolnej woli poprawiły się. Przeciwnie, uległy pogorszeniu. Trudność tym razem polega na tym, że (w tej wersji) nie ma niczego takiego, czemu można byłoby przypisać posiadanie wolnej woli. Wszak ludzie, czyli ich ciała (dla naturalisty to jedno i to samo), są nieodrodną częścią materialnej przyrody. Przyznanie ludziom wolnej woli oznaczałoby przyznanie im (czyli ich ciałom!) możliwości ingerowania z zewnątrz w świat fizycznej przyrody; mówiąc innymi słowy, oznaczałoby przypisanie im daru dokonywania nieustannych cudów. Na coś takiego naturalista, rzecz jasna, nie może przystać. Wszak ludzie, czyli ich ciała, stanowią nieodrodną część materialnej przyrody.

W naturalistycznej perspektywie nie ma miejsca dla żadnych bogów, również dla „quasi-bogów”, którymi mieliby być ludzie suwerennie kierujący swym zachowaniem. W wersji religijnej funkcję quasi-bogów pełnią niematerialne ludzkie dusze, które nie są częścią materialnej przyrody i które - korzystając z tajemnej władzy nad ciałem - zmuszają je do określonych zachowań. Gdyby nie to, że Bóg zna z góry ich postanowienia, to nie byłoby żadnego problemu.

W wersji naturalistycznej nie ma Boga, ale nie ma również niematerialnych dusz, które mogłyby ingerować w bieg zdarzeń. Fizyczny świat, co lubią podkreślać naturaliści, jest domknięty ze względu na związki przyczynowo-skutkowe. W tym stanie rzeczy nie wiadomo, kto lub co miałoby posiadać wolną wolę. Ani ciała ludzi, ani żadna ich część po prostu nie nadaje się do tego, aby być podmiotem wolnej woli. Nie ma nikogo (ani niczego), kto mógłby sprawić, że warunek (A) naszej definicji byłby spełniony.

Zauważmy, że gdybyśmy wyeliminowali z naszej ontologii wszechwiedzącego Boga, ale zachowali niematerialną duszę, to wolna wola byłaby ocalona. Oczywiście owa dusza (substancja myśląca, podmiot, osoba...; mniejsza o nazwę) musiałaby posiadać możliwość (i korzystać z tej możliwości) ingerowania w świat fizycznych zdarzeń i procesów. Gdyby naturaliści zechcieli zatrzymać się w połowie drogi..., ale oni muszą znaturalizować wszystko. Cały wysiłek współczesnych naturalistów jest skoncentrowany na pełnej, pozbawionej jakichkolwiek luk naturalizacji człowieka.

Zauważmy ponadto, że ci (filozofowie, teolodzy itd.), którzy utrzymują, że istnieje wszechwiedzący Bóg oraz niematerialna dusza i próbują w tej sytuacji znaleźć miejsce dla wolnej woli, są w lepszej sytuacji niż ci, którzy są naturalistami i próbują ocalić wolną wolę. W pierwszym przypadku są możliwe różne metafi- 
zyczne manewry, natomiast w drugim sprawa wydaje się beznadziejna w punkcie wyjścia; po prostu nie ma niczego takiego, co mogłoby posiadać ten dar.

W związku z powyższym nasuwa się następujące pytanie. Dlaczego w ogóle naturaliści zmagają się z problemem wolnej woli? Czy nie powinni oświadczyć, że czegoś takiego po prostu nie ma i być nie może w fizycznym świecie? Wolna wola pozostaje dla naturalistów problemem, jak sądzimy, co najmniej z dwóch powodów. Po pierwsze dlatego, że bardzo trudno jest wyjaśnić wszystkie ludzkie zachowania w sposób całkowicie naturalny. I po drugie dlatego, że wszystkie nasze (tzn. ludzkie) instytucje i wszystkie kontakty pomiędzy ludźmi (sformalizowane lub czysto prywatne) są oparte na założeniu, że ludzie posiadają wolną wolę. Pojęcie wolnej woli jest nierozerwalnie powiązane z pojęciem odpowiedzialności. Jeżeli nie ma wolnej woli, to nie ma i sprawców. Jeżeli nie ma sprawców, to nikt nie jest za nic odpowiedzialny. Jeżeli nikt nie jest za nic odpowiedzialny, to... oznacza to prawdziwą katastrofę. Jeżeli usuniemy wolną wolę (a wraz z nią sprawstwo i odpowiedzialność), to cały ludzki „świat” legnie w gruzach.

Bardzo trudno jest sobie wyobrazić, jak by było, gdyby nie było wolnej woli, sprawców i odpowiedzialności. Próbować można. A więc, po pierwsze, wymiar sprawiedliwości traci sens, bo gdy nie ma sprawców, nie ma również winnych i niewinnych. Nie ma również kogo nagradzać. Jeżeli nie ma sprawców, to nie ma również kogo cenić (jakże można byłoby cenić fizyko-chemiczne procesy), nie ma komu być wdzięcznym, nie ma się na kogo obrażać, ani kogo szanować (szanuję fizyko-chemiczne procesy zachodzące w jego głowie???). A co z przyjaźnią, zaufaniem, miłością... No i wreszcie, co ze mną, autorem tej pracy. Kim ja właściwie jestem? Zbiorem procesów fizyko-chemicznych, na które nie mam żadnego wpływu?

Jeżeli wolna wola jest złudzeniem, to wiele innych rzeczy też jest złudzeniem. Żyjemy jak we śnie. Naprawdę byłoby lepiej, gdyby istniała wolna wola, sprawcy i odpowiedzialność!

Piszący niniejsze jest zdania, że problem wolnej woli jest jednym z najważniejszych problemów współczesnej (naturalistycznej) filozofii umysłu.

Nim zakończymy ten paragraf, powróćmy raz jeszcze do naszego przykładu z panią Agnieszką i panem Piotrem oraz załóżmy tym razem, że zarówno pani Agnieszka, jak i pan Piotr są wojującymi naturalistami, przeświadczonymi o trafności takiego stanowiska. Załóżmy dalej, że pani Agnieszka spotyka pana Piotra w środę i żąda wyjaśnień dotyczących niewywiązania się z obietnicy oddania pieniędzy we wtorek. A teraz wyobraźmy sobie, że wyjaśnienia pana Piotra wyglądają mniej więcej tak: Droga Agnieszko, wiem, że, tak jak i ja, jesteś naturalistką. Porozmawiajmy poważnie, jak naturalista z naturalistką. Otóż, oboje wiemy, że abym mógł oddać Ci pieniądze w miniony wtorek, dokładnie o godz. 10, to w moim ciele, a w szczególności w mózgu musiałyby zajść niezwykle skomplikowane fizykochemiczne procesy. Skoro nie oddałem pieniędzy, to najwidoczniej wspomniane procesy nie zaszły. Nie rozumiem więc, skąd te pretensje $i$ żale. Czy to moja wina, że nie zaszły? Czy sądzisz, że miałem jakikolwiek wpływ na owe procesy? Czyżbyś mniemała, że jestem jakimś 
demonem, który wedle upodobania steruje owymi procesami, kontroluje to, co dzieje się na synapsach i wytrąca molekuły z ich naturalnego biegu. Gdybyś była kartezjanistką, to rozumiem... Ale między nami, naturalistami, nie powinno być takich nieporozumień. Jeżeli już koniecznie chcesz mieć pretensje i na kogoś się obrazić, to obraź się na mój mózg. Obrażanie się na mózg byłoby jednak równie śmieszne jak obrażanie się na żołądek czy wątrobę. Agnieszko, jak Ci nie wstyd. Myślałem, że jesteś wyzwolona z kartezjańskich przesądów.

Wypowiedź pana Piotra, którą zakończyliśmy poprzedni akapit sprawia wrażenie filozoficzno-naturalistycznego żartu. Ludzie tak się nie tłumaczą. Czy to znaczy, że nie traktują poważnie swoich naturalistycznych przeświadczeń? W pewnym sensie tak. Naturalistyczna metafizyka to doktryna, której bronimy (my - naturaliści) na seminariach i za którą się opowiadamy w kawiarnianych dyskusjach. Prawdziwe życie, rzeczywiste kontakty pomiędzy ludźmi są jednak inne. Zachowujemy się tak, jakby istniała wolna wola, odpowiedzialność i sprawcy. Dlaczego jednak? Czy to tylko siła tradycji i wychowania opartego na wierze w mity? Nie sądzę. Uważam, że przyczyny są zupełnie inne. Najłatwiej będzie mi je przedstawić, posługując się opowiadaniem z gatunku science fiction. Jest to w końcu ulubiona forma współczesnych filozofów umysłu.

\subsection{Doskonała teoria profesora Prognozy}

„Zdarza się, że błądzę... llekroć jednak w grę wchodzi sprawstwo, zawsze jestem tego świadom" - zwykł mawiać Sherlock Holmes. Słynny detektyw nie dodawał - było to zbyt oczywiste - że ilekroć w grę wchodzi sprawstwo, plan lub intryga, musi również istnieć jej autor. Poszukiwanie sprawcy bywa - nie tylko w kryminalistyce - odruchem, któremu bardzo trudno jest się oprzeć. Poszukiwania tego rodzaju stanowią stały element naszej codziennej praktyki. Na ogół zresztą nie doznajemy zawodu i, o ile jesteśmy dostatecznie wytrwali, udaje nam się odnaleźć tego, który wybił szybę, podłożył bombę lub napisał poemat. Jest nim zawsze (a przynajmniej taka jest praktyka) pewien człowiek. Jeżeli, śledząc (niekiedy bardzo długi) łańcuch kolejnych przyczyn i skutków, uda się nam wreszcie dotrzeć do pewnego człowieka, to decyzji, które podjął, wyborów, których dokonał nie traktujemy jako kolejnego ogniwa w ciągu zdarzeń. Uznajemy poszukiwania za zakończone. Sądzimy, że znaleźliśmy pierwszą przyczynę zła (lub dobra), które zaszło. Teraz możemy wreszcie wymierzyć karę lub wręczyć nagrodę. Dalsze poszukiwania - sądzimy - nie miałyby sensu. Wszak znaleźliśmy „pierwszego poruszyciela".

Pojęcie sprawstwa jest powiązane z problemem wolnej woli. Wolna wola to dar, który mieliby posiadać sprawcy. Gdyby go nie posiadali, to nie byliby - skłonni jesteśmy mniemać - prawdziwymi sprawcami. Któż to jednak taki, ów sprawca? I co to właściwie miałoby znaczyć, że dysponuje on wolną wolą? Staraliśmy się na te pytania odpowiedzieć w poprzednich paragrafach. W tym będziemy się starali 
wyjaśnić, dlaczego ludzie w ogóle odczuwają potrzebę posługiwania się pojęciem sprawcy i przypisywania mu daru zwanego wolną wolą.

Opisując zmienne koleje aury, kwitnienie tulipanów lub lot biedronki obywamy się bez pojęcia sprawcy. Sprawstwo i wolna wola, to „wynalazki”, mające zastosowanie wyłącznie w obrębie ludzkiego świata. Dlaczego jednak? Dlaczego, opisując ludzi, używamy tych pojęć, a opisując zachowanie biedronek, telewizorów czy komputerów nie odczuwamy takich pokus? Pytania te zadaję rutynowo studentom różnych lat i kierunków wówczas, gdy prowadzę zajęcia poświęcone problemowi wolnej woli. Najbardziej typowe i najczęstsze odpowiedzi wskazują na znacznie większy stopień komplikacji ludzkich organizmów i na zasadniczą nieprzewidywalność ludzkich zachowań. Można się jednak również dowiedzieć, że wolna wola i sprawstwo, to wymysł teologów, a ostatnimi czasy także, iż winien jest tutaj właściwy ludziom szowinizm gatunkowy, szowinizm białkowy (pierwszy miałby dyskryminować zwierzęta, drugi - artefakty). Wszystkie te odpowiedzi są, moim zdaniem, całkowicie błędne. Sądzę, że wolna wola, to nazwa ukuta na określenie pewnej dyspozycji czy też władzy lub daru.. Jeżeli nie prowadzimy rozważań na poziomie ustaleń filozoficzno-teoretycznych, ale przyjrzymy się praktyce dnia codziennego, to $w$ dyspozycji tej nie ma nic tajemniczego i choć nie potrafimy wykazać realności tego daru w taki sposób, który zadowoliłby sceptycznie nastawionego filozofa, to wydaje nam się, że wiemy, dlaczego ludzie przypisują go sobie wzajemnie. Przypisywanie wolnej woli ludziom, a odmawianie jej biedronkom, koniom, pralkom automatycznym czy komputerom nie ma nic wspólnego ani z teologią, ani z szowinizmem. Powód jest całkowicie inny. Aby wyjaśnić, co mam na myśli i lepiej niż do tej pory określić interesującą nas dyspozycję, posłużymy się historyjką z gatunku science fiction. Opowieść jest fantastyczna i dotyczy przyszłości, ale „morał”, który z niej wynika jest oparty na oczywistych i dobrze znanych faktach. Aby wyraźnie ją oddzielić, nadam jej osobny tytuł. Oto moja historyjka.

\subsubsection{Skanery i neurony}

Wyobraźmy sobie, że żyjemy gdzieś w roku 2050 i że nauka o mózgu osiągnęła zadziwiający stopień rozwoju. Powstały zresztą całkowicie nowe jej działy. Dyscyplina, która cieszy się największym zainteresowaniem i która rozwija się najszybciej to tzw. prognostyka neurologiczna. Ma ona tylko jeden cel i jedno zadanie - przewidywać zachowanie żywych organizmów: ryb, psów, kotów oraz... ludzi. Fakt, że prognostykę neurologiczną stosuje się w równej mierze do koni i do ludzi wywołał zresztą sporo emocji oraz wiele niezrozumiałych protestów. Opory i zastrzeżenia, podnoszone przez ignorantów, zostały jednak ostatecznie przezwyciężone i obecnie nic już nie hamuje rozwoju tej nowej i fascynującej dyscypliny. Prognozowanie neurologiczne w odniesieniu do ludzi stało się możliwe i nabrało realnych kształtów dzięki skonstruowaniu urządzenia (będącego owocem pracy wielu różnych specjalistów z wielu różnych dziedzin), zwanego skanerem mózgu. Pomińmy szczegóły techniczne. Skaner mózgu to aparat umożliwiający uzyskanie najważniejszych informacji dotyczących aktualnego stanu mózgu 
(z uwzględnieniem wszystkich połączeń i stężenia wszystkich przekaźników we wszystkich szczelinach synaptycznych między neuronami) skanowanego osobnika. Wyjaśnijmy jednak, na czym polega przewidywanie. Otóż, dobrze wyszkolony specjalista (prognosta neurologiczny), wyposażony we wspomniany skaner oraz specjalny komputer, jest w stanie przewidzieć w ogólnym zarysie początkowe zachowania ludzkiego osobnika w z góry zadanym środowisku. W praktyce wygląda to mniej więcej tak.

Załóżmy, że właśnie zeskanowaliśmy mózg osobnika A. Już za chwilę znajdzie się on w specjalnym pokoju. Specjalny pokój to właśnie owo „z góry zadane środowisko". Może ono wyglądać nader różnie. Dla ustalenia uwagi przyjmijmy, że tym razem jest to niewielka izba, w której znajduje się stół, dwa fotele (F1 i F2) oraz półka z pięcioma książkami (K1,.. K5). Nim osobnik A wejdzie do opisanej właśnie izby, dane ze skanera są (możliwie najszybciej) wprowadzane do komputera wyposażonego w specjalny program. Zadaniem programu jest symulowanie zachowania ludzkiego osobnika o takim to a takim stanie mózgu, w takim to a takim środowisku. W tym samym momencie, w którym rozpoczyna się symulacja, osobnik A wkracza do specjalnego pokoju. Gdzieś obok znajduje się sala szczelnie wypełniona prognostami neurologicznymi i wyposażona w dwa wielkie ekrany. $\mathrm{Na}$ pierwszym obserwują oni rzeczywiste zachowania rzeczywistego osobnika A w rzeczywistym, choć specjalnie spreparowanym środowisku; na drugim - symulację. W ten sposób każdy - fachowiec bądź laik - może łatwo ocenić siłę prognostyczną wiedzy, jaką udało się uczonym-przyrodnikom posiąść o ludzkich organizmach. Jest ona doprawdy niezwykła. Rzeczy, które do niedawna przekraczały granice wyobraźni, stały się możliwe, a nawet znalazły się w zasięgu ręki. Wystarczy wspomnieć, że rzeczywistość nieomal nigdy nie rozmija się w istotny sposób z symulacją w przeciągu pierwszych kilku sekund. Tak więc, jeśli wirtualny osobnik $A$ rozpoczyna od tego, że siada $w$ fotelu $F 1$, to czyni to również rzeczywisty A; jeśli symulacja przewiduje, że A wpierw podejdzie do półki z książkami, to tak właśnie się dzieje itd. Zachowania rzeczywistego osobnika A i jego wirtualnego odpowiednika nie są jednak dokładnie takie same nawet w przeciągu kilku pierwszych sekund. Drobne różnice szybko się kumulują (a dobrze skądinąd wiadomo, że w tym przypadku minimalne różnice w przyczynach prowadzą - zdarza się - do kolosalnych różnic w skutkach) i w miarę upływu czasu zachowania osobnika A i jego numerycznej kopii stają się coraz mniej podobne. Po minucie rzeczywistość i symulacja to już całkowicie dwa różne ciągi zdarzeń. Oto jeden przykład. Osobnik rzeczywisty i wirtualny podchodzą do półki z książkami, biorą książkę K4 i obaj otwierają ją mniej więcej w taki sam sposób. Osobnik rzeczywisty otwiera ją jednak na stronie 25 , a wirtualny na 29 . Osobnik rzeczywisty pochyla się nad książką i coś czyta, podczas gdy jego wirtualny odpowiednik odkłada K4 i bierze K5. Osobnik rzeczywisty podchodzi do okna z otwartą książką; osobnik wirtualny udaje się z K5 w kierunku fotela itd. Dalsza zabawa nie ma sensu. Aby ponownie upodobnić symulację do rzeczywistości, trzeba od nowa skanować mózg. Metoda ta więc, jak widać, ma swoje ograniczenia. Uczeni-specjaliści z wielu różnych dziedzin pracują już jednak nad skanerem drugiej generacji... Wobec opisanego stanu, psychologia tradycyjna, ta dziwna mieszanina ludowych wierzeń i baśnio- 
wej ontologii (przekonania, wrażenia, sentymenty itd.) znajduje się w całkowitym odwrocie i już prawie nikt nie wątpi, że wkrótce podzieli los alchemii.

Przedstawiony tu stan rzeczy może się wydać zbyt fantastyczny, aby zasługiwał na poważne potraktowanie. W piśmiennictwie naukowym i popularnonaukowym wiele jest jednak teraz (w pierwszej połowie XXI wieku) takich właśnie opisów. Weźmy go więc za dobrą monetę. Być może to, co napisałem powyżej jest niefachowe lub nieudolne i ekspert od mózgu i neuronów przedstawiłby to zupełnie inaczej. Zgoda - jestem w tych sprawach laikiem. Nie wydaje mi się to jednak aż tak ważne. Chodziło mi po prostu o wyobrażenie sobie pewnego przyszłościowego stanu, w którym wiedza o budowie i sposobie funkcjonowaniu mózgu posiadałaby czytelną i dającą się ocenić wartość prognostyczną. Póki co, siła prognostyczna tej wiedzy jest bardzo niewielka. Aby wyjaśnić, co mam na myśli, posłużę się prostym przykładem. Ekspert od balistyki, po zapoznaniu się z aktualnym stanem armaty i środowiska, tzn. po zapoznaniu się z kątem ustawienia lufy, siłą i kierunkiem wiatru itd., jest w stanie przewidzieć, gdzie i kiedy (z dokładnością do iluś tam metrów i sekund) spadnie pocisk. Ekspert od spraw mózgu i neuronów, po zapoznaniu się z aktualnym stanem mózgu i neuronów ( $w$ takim zakresie, w jakim to jest obecnie możliwe) pewnego ludzkiego organizmu, nie wie (o ile wiem), co i kiedy ten organizm zrobi: czy i kiedy włączy telewizor, czy i kiedy usiądzie na krześle itd. Ktoś mógłby rzec, że nie można mózgu porównywać $z$ armatą i że przykład jest niedorzeczny. Ja jednak nie porównuję mózgu $z$ armatą, tylko siłę prognostyczną wiedzy balistycznej z siłą prognostyczną wiedzy neurologicznej. Pierwsza jest olbrzymia, druga - póki co bliska zeru. Kontrast ten stanie się jeszcze wyraźniejszy, jeśli uświadomimy sobie, że balista jest w stanie przewidzieć nie tylko, gdzie spadnie pocisk, ale ponadto gdzie spadłby, gdyby kąt ustawienia lufy był zupełnie inny, a wiatr wiał z inną siłą i w innym kierunku. Gdzież ekspertowi od neuronów do takiej wiedzy! To, czy jakiś rodzaj tzw. wiedzy naukowej posiada dużą czy małą siłę prognostyczną, najlepiej można sobie uświadomić, próbując odpowiedzieć na pytanie, czy i w jakim zakresie zwracamy się do ekspertów, gdy jesteśmy zainteresowani przyszłym zachowaniem pewnych obiektów. Otóż, jeżeli chcemy wiedzieć, gdzie i kiedy spadnie pocisk, to zwracamy się do balisty; jeżeli chcemy wiedzieć, o której zajdzie słońce lub kiedy nastąpi zaćmienie księżyca, to prosimy o pomoc astronomów itd. Jeżeli natomiast pragniemy wiedzieć, co pewien człowiek zrobi następnego dnia wczesnym rankiem lub jak zachowałby się w określonej sytuacji - w kinie lub na pustyni - to nie „biegniemy z tym" do neurobiologa. Doskonale wiemy, że tym razem uczony-specjalista nie potrafiłby nam w niczym pomóc. Z całym szacunkiem dla wiedzy o mózgu, zgódźmy się, że - póki co - siła prognostyczna tej wiedzy jest bardzo niewielka. Wiedza ta ostatnimi czasy rozwija się jednak bardzo szybko. Być może więc w niedalekiej już przyszłości wzrośnie również znacznie jej siła prognostyczna. Oczywiście, eksperci od neuronów nigdy nie będą w równie komfortowej sytuacji, jak np. astronomowie. Wynika to z samej natury przedmiotu ich badań. Te wszystkie synapsy, transmitery, stężenia... Zbyt wiele różnych i zbyt skomplikowanych rzeczy (i zbyt szybko) dzieje się w zbyt wielu różnych miejscach, aby umysł badacza mógł to wszystko ogarnąć... Trzeba byłoby dopiero jakiegoś demona. Taki „demon” wkrótce już będzie gotowy - zapewniają nas entuzjaści tzw. cognitive science. Będzie nim po prostu skaner 
mózgu (którejś generacji) połączony z komputerem którejś generacji. Urządzenia te -niczym demon Laplace'a - wszystko „zobaczą", przetworzą, ocenią i, w końcu, przewidzą. Aby mówić o przewidywaniu we właściwym znaczeniu tego słowa, symulacja musiałaby jednak - choć trochę - wyprzedzać rzeczywistość. Załóżmy, że nie są to czcze fantazje. Przyjmijmy raz jeszcze, że żyjemy w roku 2050 i że uczeni, progności neuronowi, są w stanie przewidzieć (w opisany sposób) początkowe zachowania dowolnego człowieka w odpowiednio spreparowanym środowisku.

Przedmiotem tego rozdziału jest sprawstwo i wolna wola. Dywagacje dotyczące siły prognostycznej różnych rodzajów wiedzy i podróż w 2050 r. nie odwodzą nas jednak od tego tematu i już wkrótce okażą się bardzo pomocne. Aby jasno wytłumaczyć, dlaczego ludzie posługują się pojęciem wolnej woli i sprawstwa, muszę wykonać jeszcze jeden manewr. Wprowadzę postać, którą w dalszym ciągu będę zwał profesorem Prognozą. Imię własne profesora jest znaczące. Nazwałem go tak dlatego, że profesor dysponuje wiedzą o niezwykłej sile prognostycznej. Nie są to zresztą jedyne zalety wiedzy, którą posiadł. Sądzę, że najlepiej będzie, jeżeli oddamy głos samemu profesorowi.

\subsubsection{Opowieść profesora Prognozy}

Szanowni Panowie, prognostycy neurologiczni. Jestem twórcą teorii, która „bije na głowę” Wasze skanery, komputery i symulacje. Pozwólcie, że wpierw opiszę Wam zalety mojej teorii. Są one doprawdy niezwykłe. Dodajmy, że natychmiast po moim wystąpieniu będziecie mogli sprawdzić, czy mówiłem prawdę. Oto właściwości mojej teorii.

Po pierwsze, jestem w stanie (w zasadzie) przewidzieć dowolnie odległą przyszłość. To żadna sztuka przewidzieć, co pewien człowiek zrobi za chwilę. Prawdziwą sztuką jest przewidzieć, co zrobi on za godzinę, dwie lub za tydzień. Ja to potrafię! Potrafię przewidzieć, co przedmiot moich prognoz - jest to ściśle określony człowiek - zrobi za tydzień o ściśle określonej porze, jak będzie ubrany, co powie, którą rękę opuści i gdzie się podrapie... Mogę Wam podać dowolną liczbę szczegółów. Nie pomylę się ani co do tych szczegółów, ani co do kolejności. Pragnę jednak zaznaczyć, że okres objęty przewidywaniem nie może być zbyt długi. Korzystając ze swej teorii, po prostu szybko się męczę, a i zwyczajnie nudzę. Przejdźmy jednak do tego, co bardziej godne uwagi. Mam na myśli zalety praktyczne mojej teorii.

Otóż, po drugie, moja teoria jest niewyobrażalnie prosta w użyciu. Aby się nią posługiwać, nie trzeba ani badać mózgu, ani nawet się jej (tzn. teorii) uczyć. Szanowni Państwo, tego jeszcze nie było! Stworzyłem teorię tak bajecznie prostą „w obsłudze”, że można jej używać, w ogóle się jej nie ucząc. Dzięki temu mogą z niej korzystać wszyscy; także analfabeci i małe dzieci.

Po trzecie wreszcie... (słuchajcie uważnie, gdyż jest to prawdziwy przełom!). Otóż, największą wadą wszelkiej znanej do tej pory wiedzy było to, że przewidywania uzyskiwane w oparciu o tę wiedzę mogły się rozmijać (i często się rozmijały) z oczekiwaniami i potrzebami użytkowników tejże wiedzy. Meteorolog chciał, 
aby świeciło słońce, a wiedza meteorologiczna kazała mu przewidywać, że będzie padać deszcz; astronom życzył sobie, aby zaćmienie nastąpiło w czwartek, a z wiedzy astronomicznej wynikało, że nastąpi w piątek itd., itd. Dość tej tyranii. Wiedza powinna służyć ludziom, a nie ludzie wiedzy. Moja teoria spełnia ten postulat. Każdy, kto zdecyduje się skorzystać z mojej teorii, wpierw wybierze sobie przyszłość, a dopiero później ją przewidzi. Od tej pory żadnych niespodzianek i żadnych przykrych prawd. Podobnie jak w sklepie z konfekcją, wpierw starannie wybieramy i przymierzamy płaszcz, a dopiero później go kupujemy, tak też od tej pory wpierw starannie wybierzemy przyszłość, a dopiero później ją przewidzimy. Już najwyższy czas, żeby teorie naukowe wyszły naprzeciw wymaganiom klientów i, co się tyczy przewidywań, zaspokajały ich gusta.

Interesuje Was zapewne, w jaki sposób przewiduje się na podstawie mojej teorii. Zdradzę Wam tę tajemnicę. Skupcie się. Otóż, na podstawie mojej teorii przewiduje się po prostu przez oznajmienie tego, co się przewiduje! Wystarczy to wypowiedzieć lub napisać. Oto prosty przykład właściwego posłużenia się moją teorią. Na podstawie teorii profesora Prognozy przewiduję, że pan $X$ dokładnie za godzinę podniesie do góry prawą rękę, następnie opuści ją z wolna i podniesie lewą, po czym podejdzie do półki z książkami i dotknie wskazującym palcem prawej ręki książkę znajdującą się w prawym górnym rogu. Prawda, że to proste? Jeżeli jednak sądzicie, że teraz (gdy zdradziłem Wam sposób posługiwania się moją teorią) możecie się już beze mnie obejść, to grubo się mylicie. Aby móc korzystać z mojej teorii, trzeba ją ode mnie kupić. Cena zależy, rzecz jasna, od tego, w jaki sposób klient zamierza posłużyć się moją teorią, tzn. co i kiedy zamierza przewidzieć. Chciałbym Was jednak przestrzec. Jestem nie tylko geniuszem, ale i moralistą. Nie sprzedam żadnego egzemplarza mojej teorii nikomu, kto pragnie jej użyć do niecnych celów i przewidywać gwałty, kradzieże, morderstwa... i temu podobne niecne uczynki.

Dotąd mówiłem tylko o zaletach. Pora wspomnieć o wadach. Otóż, moja wspaniała teoria stosuje się tylko do jednego obiektu. Pan X, o którym wspomniałem podając przykład, to konkretny człowiek i moja teoria dotyczy właśnie tego człowieka. Przyznaję - jest to istotne ograniczenie. Sami chyba jednak rozumiecie, że zdobycie wiedzy o tak niezwykłej sile prognostycznej wymaga bardzo wąskiej specjalizacji. Całe swoje życie poświęciłem badaniu neuronów pana $X$ i poznałem je dogłębnie. Co się tyczy pana Y-eka lub pani Z, to jestem całkowitym ignorantem. Wiedza dotycząca mózgu pana X-a jest tak specyficzna, że okazuje się całkowicie bezwartościowa w przypadku innych ludzi. Co się tyczy pana X-a jestem jednak nie do pobicia. Toteż od tej pory, ilekroć ktokolwiek będzie żywotnie zainteresowany przyszłymi zachowaniami pana X, zwróci się do mnie, a nie do Was, progności neurologiczni.. To chyba oczywiste. Wszak znacznie lepiej jest wpierw wybrać przyszłość i dopiero później ją przewidzieć niż przewidzieć jakieś „nie wiadomo co?". Prawa wolnego rynku są nieubłagane. Zamierzam zresztą sprzedawać egzemplarze swojej teorii w jednej czwartej ceny skanera.

Nim skończę, muszę jeszcze zapoznać Was z nazwą, którą nadałem swej teorii. Długo myślałem nad tą sprawą. Przymiotniki takie jak „idealna” czy „doskonała" wydały mi się stanowczo zbyt słabe na określenie teorii, która umożliwia 
przewidywanie poprzez przewidywanie. Jej zalety leżą jakby poza zasięgiem metodologicznej wyobraźni. Sądzę, że jedynie stosowną nazwą będzie niemożliwie doskonała teoria profesora Prognozy.

Aha, jeszcze jedno. Żebyście mogli sprawdzić, czy mówię prawdę, muszę ujawnić, kim jest pan X. Mam nadzieję, że nie będziecie rozczarowani. Przyznacie chyba, że to wszystko jedno, do którego człowieka stosuje się moja teoria. Poznać mózg pana $X$ jest przecie równie trudno jak pana $Y$ lub pani $Z$. Fakt, że wybrałem (dla swych badań) akurat mózg pana X, a nie jakiegoś innego człowieka nie może więc mieć wpływu na ocenę mojej teorii. O ile mi wiadomo, nie wierzycie - panowie neuroprognostycy - że mam jakiś specjalny, uprzywilejowany dostęp do mózgu pana X-a, lepszy niż neurobiolodzy. Sądzić tak byłoby bzdurą, nieprawdaż? Otóż oznajmiam: pan X $\mathbf{i}$ ja, profesor Prognoza, to jeden $\mathbf{i}$ ten sam człowiek! Teraz możecie sprawdzać, czy mówiłem prawdę.

Tak kończy się opowieść profesora Prognozy.

$$
* * *
$$

Gdy dałem do oceny wstępną wersję tej pracy jednemu ze swych znajomych - zaprzysięgłemu zwolennikowi materialistycznej teorii umysłu - to ów, doczytawszy do końca powyższą opowieść, wykrzyknął: „Przecież to oczywiste! Jeżeli pan $\mathrm{X}$ i profesor Prognoza to jeden i ten sam człowiek, to nie ma tu żadnego problemu". Komentarz ten wywołał we mnie mieszane uczucia. $Z$ jednej strony ucieszyłem się, że odwołuję się do rzeczy powszechnie znanych i bezdyskusyjnych. $Z$ drugiej - zmartwiłem. Moja nadzieja na pokazanie, że są to rzeczy osobliwe i niepokojące (a przynajmniej, że takimi powinny być dla materialisty), spełzła na niczym. Komentarz ten uświadomił mi jeszcze jedno, a mianowicie, że w pewnym sensie wszyscy jesteśmy nadal (pomimo słownych deklaracji, że jest inaczej) kartezjanistami. Jeżeli ujmie się pewną rzecz nieco inaczej, w taki sposób, że nie od razu jest jasne, czego w danej sytuacji wymaga materialistyczna teoria umysłu, to natychmiast, nieomal odruchowo, powracamy do bardzo tradycyjnej interpretacji. Nie wywołuje ona wówczas ani zdziwienia, ani niepokoju - jawi się jako bezdyskusyjna i samooczywista.

Całkowicie zgadzam się ze swoim znajomym-materialistą, że jeżeli profesor Prognoza i pan X są jednym i tym samym człowiekiem, to jest oczywiste, że profesor potrafiłby do końca odegrać swoją rolę, czyli zachować się tak, jak nabywca jego teorii przewiduje. Nie zgadzam się z nim natomiast co do tego, że nie ma w tym żadnego problemu. Problem, który się tutaj pojawia, tradycyjnie rozwiązywano właśnie poprzez postulowanie istnienia podmiotu-sprawcy, obdarzonego wolną wolą. Nim przejdę do tej sprawy, chciałbym, abyśmy wyraźnie sformułowali pewną prostą, zdroworozsądkową prawdę. Brzmi ona, jak następuje:

Każdy zdrowy na ciele i umyśle człowiek potrafi (w zasadzie) odegrać w sposób udany rolę profesora Prognozy 
Podejrzewam, że moi czytelnicy są już znużeni i zniecierpliwieni. Przecież jest jasne, że nie wchodzi tutaj w grę żadna teoria i że cała ta mistyfikacja jest możliwa tylko dzięki temu, że pan X i profesor Prognoza to jedna i ta sama osoba. Rzecz jednak w tym, że wielu współczesnych filozofów umysłu (np. Fodor 1981, 1987; Churchland 1981, 1994) jest zdania, że w grę wchodzi tutaj pewna teoria zwana pogardliwie psychologią ludową (ang. folk psychology). Psychologia ludowa to teoria odwołująca się do tzw. postaw propozycjonalnych, a więc takich bytów, jak przekonania, obawy, zamiary, dążenia itd. Dzięki znajomości tych bytów (wraz z ich treściami) i dzięki wiedzy, w jaki sposób wpływają one na zachowanie, przewiduję i wyjaśniam - powiada się - ludzkie zachowania. W równej mierze innych ludzi oraz własne. Komedia z profesorem Prognozą i jego niemożliwie doskonałą teorią potrzebna mi była, aby w przekonywujący sposób podważyć tę ideę. O ile bowiem dobrze rozumiem niektórych współczesnych filozofów umysłu, to na pytanie: „Dzięki czemu każdy zdrowy na ciele i umyśle człowiek jest w stanie odegrać w udany sposób rolę profesora Prognozy?", należałoby odpowiedzieć: „Dzięki znajomości teorii zwanej psychologią ludową”. Jeżeli współcześni filozofowie umysłu mają rację, to należy przyjąć, że profesor Prognoza bynajmniej nie grał komedii, tylko rzeczywiście przewidywał swoje zachowania na podstawie pewnej teorii. To właśnie chęć sprowadzenia tego dziwacznego pomysłu do absurdu nasunęła mi pomysł profesora Prognozy i jego niemożliwie doskonałej teorii.

Jeżeli jednak w grę nie wchodzi tutaj wiedza, tzn. znajomość pewnej teorii o niezwykłej sile prognostycznej, to w jaki sposób wyjaśnić fenomen profesora Prognozy? Pytanie nasze teraz brzmi:

\section{Dzięki czemu (skoro nie dzięki teorii i przewidywaniu) każdy zdrowy na ciele i umyśle człowiek potrafi w udany sposób odegrać rolę profesora Pro- gnozy?}

Tradycyjna odpowiedź na to pytanie jest dobrze znana i brzmi: „Dzięki umiejętności sterowania własnym zachowaniem, dzięki władzy, jaką posiada nad swym ciałem, którym powoduje wedle własnego «widzimisię»". Innymi słowy, dzięki darowi zwanemu wolną wolą! Jest to prosta odpowiedź i wyjaśnia w przekonywujący sposób fenomen profesora Prognozy. Kłopot i problem polega na tym, że odpowiedź ta zakłada pewien scenariusz metafizyczny, który jest nie do pogodzenia z materialistycznym obrazem świata. Przedstawmy jeszcze raz w skrócie ten scenariusz.

\subsubsection{Ludowa metafizyka, sprawstwo i wolna wola}

Określenie „ludowa metafizyka”, tak jak chcę je rozumieć, nie posiada konotacji lekceważącej, ani, tym bardziej, obraźliwej. To, o czym będę za chwilę pisać, nie ma też nic wspólnego z folklorem. Posługuję się tym wyrażeniem tylko dlatego, że takie są obyczaje terminologiczne współczesnej filozofii umysłu. Jeżeli ja- 
kieś pojęcie związane z umysłem nie należy do żargonu ani neurobiologicznego, ani cybernetyczno-informatycznego, to znaczy, że jest ludowe. Zgodnie z tymi standardami, dziecko mówiące np., że boli je głowa uprawia ludową psychologię, gdyż odwołuje się do bytu zwanego wrażeniem bólu (powinno powiedzieć: neurony znajdujące się w sektorze U-235 są podrażnione w taki to a taki sposób) itd. Ponieważ w dalszym ciągu w tym paragrafie nie będę mówić ani o programach i neuronach (wtedy byłaby to cognitive science), ani o bólach głowy i łaskotkach (wtedy byłbym ludowym psychologiem), to - z powodu braku lepszego wyrażenia na opisanie przedmiotu swych dociekań - będę używał określenia ludowa metafizyka.

Dobrym punktem wyjścia do rekonstrukcji ludowej metafizyki jest poczucie oczywistości, którego doświadczył mój znajomy-materialista dowiedziawszy się, że pan X i profesor Prognoza to jeden i ten sam człowiek.

Otóż, casus profesora Prognozy przestaje nas zastanawiać i dziwić w momencie, gdy dowiadujemy się, że pan X i profesor Prognoza to ten sam człowiek. Dlaczego jednak? Jedyna odpowiedź, jaką znajduję, to ta, że spontanicznie, nieomal odruchowo zakładamy, że profesor Prognoza (alias pan X) pozostaje w zupełnie innym stosunku do swego umysłu i swych zachowań niż do innych umysłów i nie swoich zachowań. Osobliwość tę na gruncie dualistycznej teorii umysłu zwykło się określać mianem uprzywilejowanego dostępu. Uprzywilejowany dostęp do umysłu, ujmując rzecz z grubsza, polega na tym, że profesor wie od razu i w inny sposób rzeczy, nad którymi inni (najczęściej bezskutecznie) musieliby biedzić się latami. Uprzywilejowany dostęp do zachowań - ujmując rzecz ogólnie - polega po prostu na tym, że profesor robi co chce. Gdy chce podnieść prawą rękę, to podnosi nie nogę i nie krzesło, ale dokładnie i właśnie prawą rękę; gdy chce pokazać język, to pokazuje język itd., itd. W dalszym ciągu będzie nas interesować jedynie uprzywilejowany dostęp do zachowań. Dla uprzywilejowanego dostępu profesora do jego własnych zachowań mamy nawet specjalne określenia. Przekazała nam je w spadku tradycja filozoficzna. Otóż, uprzywilejowany dostęp profesora do jego własnych zachowań, fakt, że potrafi on podnieść swą rękę i pokazać swój język (podczas, gdy nie potrafi on podnieść ręki pana Y lub pokazać języka pani Z) zwykło się opisywać powiadając, że jest on dysponującym wolną wolą sprawcą tych zachowań. On nie przewiduje swych zachowań, on je powoduje! Dzięki tej władzy, jak sądzimy, profesor potrafi z powodzeniem udawać, że znajduje się w posiadaniu niezwykłej wiedzy, podczas gdy naprawdę umiejętnie steruje swym zachowaniem. Oto, jak sądzę, wytłumaczenie, jakie znajduje ludowa metafizyka dla fenomenu profesora Prognozy. Na gruncie tej metafizyki jest ponadto oczywiste, że każdy zdrowy na ciele i umyśle człowiek posiada ten dar. Jest też oczywiste, że każdy kto posiada ten dar, potrafiłby w udany sposób odegrać rolę profesora Prognozy.

Profesor Prognoza - to obdarzony wolną wolą sprawca. On - napiszmy to jeszcze raz - nie przewiduje swoich zachowań (tak jak astronom przewiduje zachowania księżyca), tylko je, o ile zechce, powoduje lub wykonuje. Nie wymaga to znajomości żadnej teorii. To, co profesor Prognoza wystawia na sprzedaż, nie jest żadną teorią. Proponuje nabycie swych przyszłych zachowań, a może je „sprze- 
dać" właśnie dzięki umiejętności (darowi, dyspozycji...) sterowania własnym zachowaniem.

Wiem, że to, co piszę, jest nienaukowe. Ja jednak nie przedstawiam aktualnego stanu wiedzy o mózgu, tylko rekonstruuję ludową metafizykę.

Wolna wola i sprawstwo - to ani spisek teologów, ani szowinizm gatunkowy. Nie posługujemy się tymi pojęciami, opisując biedronki lub konie dlatego, że ani biedronki, ani nawet konie nie potrafią w udany sposób odegrać roli profesora Prognozy. Nie posługujemy się tymi pojęciami, opisując artefakty dlatego, że ich przyszłe zachowania w zbyt dużym stopniu i w zbyt dużym zakresie są uzależnione od planów, zamiarów i działań konkretnych ludzi, którzy, jak sądzimy, są w tym przypadku właściwymi sprawcami. Współczesne nam artefakty nie nadają się na sprawców, choćby z tego względu, że nie musimy od nich niczego "kupować”: dostajemy od nich wszystko „za darmo”. Inaczej niż profesor Prognoza, nie mogą (nie potrafią) odmówić świadczenia usług.

Wolna wola, sprawstwo, podmiotowość itd. mają jednak ostatnimi czasy złą prasę. Są nienaukowe i sprzeczne z duchem epoki. Czy pojęcia te zostaną wyeliminowane, czy przestaniemy ich używać? Sporo w tej pracy było o przewidywaniu. Pozwolę sobie na zakończenie sformułować pewne proroctwo. Otóż, pojęcia wolnej woli, sprawcy, podmiotu itd. będą używane dopóty, dopóki bardziej będzie się nam „opłacało” korzystać z usług profesora Prognozy niż z usług uczonych-specjalistów. Wyjaśnijmy to dokładniej.

Otóż, jeżeli jestem zainteresowany jutrzejszą pogodą, to proszę o pomoc nie chmury i wiatry, ale meteorologów. Oni, korzystając ze swej wiedzy, potrafią przewidzieć, gdzie i kiedy będzie padał deszcz. Jeżeli natomiast jestem żywotnie zainteresowany jutrzejszym zachowaniem pana X-a, to zwracam się bezpośrednio do pana X-a. Wiem, że tym razem uczeni specjaliści - neurobiolodzy, psycholodzy - nie potrafiliby mi w niczym pomóc. Tylko pan X - alias profesor Prognoza - może mi ofiarować swe jutrzejsze zachowanie. Oczywiście, korzystanie z usług pana X-a ma swoją cenę. Pana X-a trzeba usilnie prosić; niekiedy trzeba mu ofiarować coś w zamian. W sumie jednak i tak się opłaci. Otrzymuję w zamian rzecz bezcenną, „towar”, którego nie mógłbym zdobyć w żaden inny sposób - jutrzejsze zachowanie pana X. Jeżeli pewnego dnia uznamy, że skanery i uczeni specjaliści są lepsi, szybsi, skuteczniejsi; jeżeli nadejdzie taki dzień, że miast zwrócić się bezpośrednio do pana $X-a$ zwrócę się do uczonych specjalistów, to niemożliwie doskonała teoria zostanie wyeliminowana, a wraz z nią ludowa metafizyka - pojęcia sprawcy, wolnej woli i podmiotu. Powstałby wówczas całkowicie nowy świat, w niczym nie przypominający naszego ludzkiego świata.

Czy tak się kiedyś stanie? Czy taka jest przyszłość? Nie potrafię odpowiedzieć na te pytania. Przyjrzyjmy się jednak, jak na podobne niepokoje odpowiada twórca eliminacjonizmu, Paul Churchland:

Dzięki najnowszym badaniom sieci nerwowych, zarówno zwierzęcych, jak i sztucznych, zaczynamy rzeczywiście rozumieć, jak pracuje biologiczny mózg - twój i każdego innego człowieka. Ktoś mógłby uznać to za zagrożenie: jego najbardziej intymne sekrety mogłyby zostać ujawnione, ogłoszone publicznie. Zachowajmy spokój. Jak to zostanie wyjaśnione [...], fizyczny mózg jest zbyt skomplikowany i zbyt dynamiczny, by można było przewidzieć jego zachowanie inaczej niż tylko w bardzo 
ogólnych zarysach i w bardzo krótkim czasie. Z uwagi na te dynamiczne właściwości funkcjonującego mózgu żadne urządzenie możliwe do skonstruowania w tym wszechświecie nie będzie nigdy zdolne przewidzieć naszego zachowania [...] (Churchland 2002: 11)

Jeżeli Churchland ma rację i fizyczny mózg jest zbyt skomplikowany i zbyt dynamiczny, by można było przewidzieć jego zachowanie inaczej niż tylko w bardzo ogólnych zarysach i w bardzo krótkim czasie oraz prawdą jest, że $z$ uwagi na te dynamiczne właściwości funkcjonującego mózgu żadne urządzenie możliwe do skonstruowania w tym wszechświecie nie będzie nigdy zdolne przewidzieć naszego zachowania, to pojęcia sprawcy, wolnej woli, podmiotu i ludowa metafizyka nigdy nie zostaną wyeliminowane. W końcu profesor Prognoza radzi sobie bez trudu z rzeczami, o których wspomina Churchland (i to bez żadnych urządzeń). Czyżby wiedział i mógł więcej niż badacze mózgu? Być może zatem ludowa metafizyka (wraz ze sprawcą obdarzonym wolną wolą) jest w ogólnym zarysie po prostu prawdziwa? Być może.

$\mathrm{Na}$ koniec dygresja. Jeżeli Churchland jest tak sceptycznie nastawiony do możliwości prognostycznych, jakie oferuje nam wiedza o mózgu, to dlaczego głosi eliminacjonizm? Czy dlatego, że nie zdaje sobie sprawy z istnienia profesora Prognozy?! 


\author{
Rozdział szósty
}

\title{
PROBLEM QUALIÓW
}

\section{Problem qualiów (krótkie wprowadzenie)}

Niematerialnego umysłu nie ma, ostała się jeno cielesna machina. Nie sposób jednak zaprzeczyć temu, że rozglądając się wokół zauważamy, że jedne rzeczy (obiekty) są zielone (np. trawa), inne czerwone (np. dojrzałe pomidory), a jeszcze inne białe (np. śnieg) itd., itd. Nie sposób również zaprzeczyć temu, że konsumując obiad konstatujemy, że spożywane potrawy są gorzkie, słone, kwaśne, słodkie itd., itd., ani temu, że przeciągając ręką po blacie biurka czujemy, że jest ono gładkie lub szorstkie, zimne lub gorące itd., itd. Otóż wszystkie „byty”, których nazwy wyróżniliśmy kursywą są zwane przez współczesnych filozofów umysłu qualiami. Listę tę można łatwo poszerzać. Słuchając np. koncertu, obcujemy z ogromną liczbą qualiów, powiązanych ze zmysłem słuchu. Qualia niekoniecznie i nie zawsze powiązane są z tym wycinkiem świata, który znajduje się w zasięgu naszego wzroku, słuchu, dotyku... Wszelkiego rodzaju bóle, łaskotania, swędzenia itd. zaliczane są do kategorii qualiów. Niektóre qualia, wydaje się, nie mają lokalizacji przestrzennej, a przynajmniej tak są odczuwane przez tych, którzy ich doświadczają. Przykładami mogłyby tutaj być np. nastroje - smutku, radości, niepokoju itd., itd.

Oczywiście qualiów jest nieporównanie więcej i (ewentualny) czytelnik, zachęcony tym, co napisaliśmy w poprzednim akapicie, z łatwością poszerzyłby listę o własne przykłady. Ktoś jednak mógłby zaoponować. Dość przykładów. Czy nie lepiej byłoby podać definicję? Z definicją jednak są kłopoty. Przyczyn tych kłopotów jest zapewne wiele, ale jedna jest chyba najważniejsza. Otóż, definiens takiej definicji musiałby odwoływać się do tego, co ludzie widzą, słyszą, wyczuwają zmysłem dotyku, powonienia itd., itd. W związku z tym nasuwa się od razu pytanie: Którzy ludzie? Łatwo można sobie uzmysłowić, że nie jest to pytanie bezzasadne. Załóżmy, że próbuję wyjaśnić komuś, co mam na myśli, używając słowa czerwony i powiadam mniej więcej coś takiego: „Spójrz na dojrzałego pomidora. Jest on 
czerwony". Jeżeli osoba, do której mówię, jest daltonistą, to z pewnością nie widzi tego samego, co ja widzę i nie udało mi się wyjaśnić, co mam na myśli, używając słowa czerwony. Okoliczność, że daltonizm jest niezwykle rzadki nie ma tutaj specjalnego znaczenia. Istotne jest tylko to, że daltonista, aby zrozumieć, czym jest czerwień i co mam na myśli mówiąc, że ten oto pomidor jest czerwony, musiałby, wydaje się, posiadać doznania wzrokowe zbliżone do moich. Jeżeli ich nie ma, to sytuacja, wydaje się, jest beznadziejna. I w ten oto sposób doszliśmy do czegoś, co w tradycyjnej (czyli kartezjańskiej) filozofii zwykło się nazywać uprzywilejowanym dostępem. Ja mam dostęp do czegoś, do czego daltonista nie ma dostępu i, jak sądzę, mieć nie może. W dalszym ciągu poświęcimy tej osobliwości sporo miejsca. Póki co, chcieliśmy wyjaśnić, dlaczego autorzy pisujący o qualiach wolą przykłady od definicji. Ukrytym założeniem wszystkich tych przykładów jest przekonanie, że czytelnicy posiadają doznania zbliżone do doznań autorów tekstów.

Jeżeli kogoś nie zadowalają dotychczasowe wyjaśnienia, to proponuję krótki eksperyment myślowy. Spróbujmy sobie wyobrazić, jak wyglądałby świat, gdyby nie było qualiów. Nic nie byłoby ani czerwone, ani zielone, ani niebieskie..., ani twarde czy miękkie..., ani słodkie czy gorzkie... itd., itd. Jakby wtedy było? Byłoby tak, jakby świata w ogóle nie było! A gdyby jeszcze znikły wszystkie bóle, swędzenia, łaskotania..., wszystkie subtelne poczucia, które jakoś wiążemy z istnieniem i realnością ciała, to byłoby tak, jakby ciała nie było. A co stałoby się z myślami? Przecież myśli nie są ani zielone, ani czerwone..., ani twarde, miękkie, szorstkie czy słone. Czy w tych warunkach (tzn. bez qualiów) mógłbym sobie pomyśleć: W Wiśle żyją szczupaki albo W Wiśle żyją krokodyle, wedle upodobania? Niektórzy jednak twierdzą (np. Strawson 1994), że myśli też rozpoznajemy oraz identyfikujemy ze względu na qualia. Gdyby mieli rację, to gdybym był całkowicie pozbawiony qualiów, to nie mógłbym odróżniać i identyfikować myśli, a tym samym, wydaje się, również nie mógłbym myśleć. A więc jakby to było, gdyby w ogóle nie było qualiów? Któż to wie. Lepiej się nad tym nie zastanawiać. Wyobraźnia bywa kiepskim przewodnikiem w takich przypadkach.

Wyjaśniwszy, tak jak potrafiliśmy, co to są qualia, zauważmy co następuje. Qualia są stałym i niezwykle ważnym elementem całego naszego świadomego życia. Jeżeli tylko nie jesteśmy pogrążeni we śnie bez marzeń sennych ani nie znajdujemy się w stanie narkozy, to - chcemy tego czy nie - zewsząd otaczają nas qualia: w sklepie i w muzeum, pod prysznicem i na przystanku tramwajowym; wtedy, gdy nurkujemy i wówczas, gdy wbijamy gwoździe itd., itd.

Wszystko to prawda - mógłby powiedzieć ktoś nieobeznany z meandrami współczesnej naturalistycznej filozofii umysłu - ale gdzie tu problem! Otóż, jeżeli jesteśmy dualistami i sądzimy, że oprócz materialnych, fizycznych ciał posiadamy niematerialne umysły, to nie ma problemu, a przynajmniej wiadomo, w jaki sposób można byłoby sobie poradzić z tym problemem. A można byłoby uporać się z nim np. w taki sposób, że uznalibyśmy obecność qualiów w niematerialnym umyśle! Jeżeli natomiast jesteśmy naturalistami i, co za tym idzie, jesteśmy przekonani, że istnieje tylko świat fizyczny, to mamy problem, bardzo poważny problem. Polega on na tym, że qualia, mówiąc kolokwialnie, zupełnie nie pasują do świata odkrywanego i badanego przez fizyków, chemików, neurobiologów itd., itd. Ponieważ 
to, co tutaj piszemy, jest nieledwie krótkim i przystępnym wprowadzeniem w istotę problemu, możemy sobie pozwolić na pewną swobodę w formułowaniu pytań i wobec tego zadajmy naiwne pytanie: Gdzie właściwie znajdują się qualia?

\section{Lęk przed obrazem}

\subsection{Krzesło i jego obraz}

Jak to się dzieje, że spostrzegam np. krzesło? Przecież nie wchodzi ono ani do mojej głowy, ani do umysłu. Ani w mózgu, ani w umyśle nie ma przecież krzeseł! Pomiędzy mną a krzesłem musi istnieć jakieś pośrednictwo. A więc jak się to wszystko odbywa, jak dochodzi do tego, że widzę krzesło? Wydaje się, że sprawy muszą się przedstawiać mniej więcej tak, jak to za chwilę opiszę; co więcej, wydaje się, że po prostu inaczej przedstawiać się nie mogą. Do skonstruowania opisu posłużę się współczesnym żargonem, ale nie jest on tutaj istotny.

A więc rzecz cała, w ogólnym zarysie, musi wyglądać mniej więcej tak:

Fala świetlna pada na krzesło. Niektóre frakcje są pochłaniane, inne są odbijane i docierają do powierzchni moich oczu i pobudzają nerwy oczne w całkiem określony sposób (W tym momencie jeszcze niczego nie widzę!). Następnie impuls ten jest odpowiednio przetwarzany i przekazywany dalej do odpowiednich ośrodków w mózgu, a mianowicie tych odpowiedzialnych za widzenie. Następnie dzieje się w mózgu wiele różnych dziwnych rzeczy, o których neurobiolog zajmujący się fizjologią widzenia mógłby napisać całą książkę. Aż wreszcie, w którymś momencie wszystkie te impulsy i procesy... No właśnie i co dalej? Jak dokończyć tę krótką historię? Chciałoby się dokończyć ją jakoś tak... Aż w pewnym momencie wszystkie te impulsy i procesy zostają w jakiś sposób rozkodowane i zamieniają się na... No właśnie, na co? Chyba nie na krzesło. A jeżeli nie na krzesło, to na co? A no na coś, co można by nazwać obrazem krzesła. I w ten sposób zastąpiliśmy krzesło obrazem krzesła. Co zatem w końcu widzę? Odpowiedź się narzuca. Oczywiście to, co powstaje po rozkodowaniu wszystkich tych impulsów, to nie krzesło samo, tylko obraz krzesła.

W powyższym schemacie istotne są dwie rzeczy. Pierwsza to ta, że spostrzeganie jest przyczynowo-skutkowym procesem, przebiega w czasie, a widzenie krzesła jest zwieńczeniem tego procesu. Druga natomiast to ta, że jest taki moment $w$ tym procesie, w którym samo krzesło przestaje być istotne. Jest to ten moment, w którym impuls biegnący od krzesła (w naszym opisie fala świetlna) ulega przetworzeniu na odpowiednie procesy zachodzące w mózgu. Jest to ten moment, w którym jeszcze nie widzę krzesła, ale jego realne istnienie nie odgrywa 
już żadnej roli. Mogłoby go w ogóle nie być, a procesy w mózgu, raz w odpowiedni sposób zapoczątkowane, i tak zostałyby przetworzone w taki sposób, że widziałbym to, co widzę. Wniosek narzuca się z wielką siłą. To, co widzę, jest pewnym obrazem, reprezentacją, wyglądem czegoś, co gdzieś istnieje (być może) w świecie. Tak więc widzę obraz krzesła; zawsze i tylko, niejako z konieczności, obraz.

Przedstawiona powyżej koncepcja jest - powtórzmy to raz jeszcze - niesłychanie sugestywna i narzuca się z wielką siłą. Zdaniem olbrzymiej większości współczesnych filozofów umysłu jest ona jednak nie do przyjęcia, głównie ze względu na skrajny materializm współczesnej filozofii. Rozumują oni mniej więcej tak. Dopóki wierzono w istnienie niematerialnego umysłu, można było rozprawiać o obrazach. Malowane qualiami obrazy znajdowały się w niematerialnym umyśle. Jeżeli jednak umysłów nie ma, to nie ma i obrazów. Bo gdzież one miałyby się znajdować? Chyba nie w mózgu? W mózgu nie ma przecież żadnych obrazów. I w ten sposób obrazy znalazły się na bruku. Cóż jednak począć z tzw. qualiami? Nie da się przecież zaprzeczyć temu, że widujemy coś czerwonego, zielonego, niebieskiego itd., itd. Poradzenie sobie z qualiami bez subiektywnych obrazów wymaga jednak nieprawdopodobnej gimnastyki filozoficznej, zaakceptowania dziwactw, które wcale nie są mniej dziwne niż „malarz” w mózgu. Nie jestem w stanie opisać ich wszystkich w tym krótkim artykule. Wspomnę dwa spośród nich, te, które wydają się najbardziej wpływowe. Pierwsze to tzw. reprezentacyjna teoria qualiów w eksternalistycznej wersji (Dretske 1996; Tye 1995; Lycan 2001), a drugie to tzw. dyzjunktywizm (Hinton 1973; Snowdon 1979; McDowell 1987; Martin 2002, 2003). Nie będę ich, jako się rzekło, charakteryzował ani krytykował. Cel tego rozdziału jest inny, chodzi mianowicie o zmniejszenie lęku przed obrazem.

Żadnej silnej fobii nie można się pozbyć od razu. Dotyczy to również ikonofobii. Lęk przed obrazami będziemy redukować stopniowo, etapami. Rozpoczniemy od bardzo prostego i chyba niekontrowersyjnego przypadku, a skończymy na eksperymencie myślowym.

\section{Zmniejszanie lęku przed obrazem}

\subsection{Etap pierwszy}

Współcześni ludzie - laicy i filozofowie (bez wyjątku) - spędzają znaczną część swego świadomego życia przed ekranem telewizora lub komputera. W tym czasie (stojąc, siedząc lub leżąc) oglądają barwne i ruchome obrazy. Praktyka oglądania obrazów w ten sposób spowszedniała tak dalece, że nie budzi zdziwienia ani nie rodzi żadnych pytań. Nim zaczniemy je stawiać, poczyńmy kilka spostrzeżeń. Punktem wyjścia będzie dla nas prosty, choć nieco sztuczny przykład. Załóżmy, że wiele milionów ludzi ogląda właśnie na ekranach transmitowany na 
żywo mecz piłki nożnej. Załóżmy dalej, że każdy konsument tego ekranowego widowiska ogląda je zupełnie sam na swoim ulubionym ekranie. W praktyce sytuacje takie się nie zdarzają (gdyż emocje sportowe lubimy przeżywać wspólnie), ale łatwo mogłyby zaistnieć. W każdym razie ten banalny przykład nie powinien budzić żadnych zastrzeżeń. Przejdźmy do uwag. Otóż:

Po pierwsze, mecz jest jeden, ale ekranów, na których jest oglądany jest wiele milionów i, co za tym idzie, jest również wiele milionów obrazów. Obrazy te są bardzo podobne, choć nie identyczne. Jedne są duże, drugie małe; niektóre wyraziste, inne zamazane; jeśli natomiast ktoś ma bardzo stary telewizor, to obraz, który ogląda jest czarno-biały. Są to wszystko rzeczy oczywiste.

Po drugie, sądzę, że każdy (lub prawie każdy) przyzna, że nasi widzowie bezpośrednio oglądają tylko obrazy na ekranach. Mecz jest jeden, ale obrazów wiele i każdy widz z naszego przykładu ma dostęp tylko do tego obrazu, który znajduje się akurat na jego ekranie. Pozwólmy sobie na odrobinę terminologicznej ekstrawagancji i powiedzmy, że każdy z naszych widzów posiada uprzywilejowany dostęp tylko do jednego obrazu. Oczywiście, nie jest to uprzywilejowany dostęp w kartezjańskim sensie. Każdy widz z naszego przykładu mógłby (w zasadzie) uzyskać taki sam dostęp do wszystkich pozostałych ekranów. Dopóki jednak warunki przykładu są spełnione, każdy ma dostęp tylko do swojego ekranu i tylko do tego obrazu, który pojawia się na jego ekranie.

Po trzecie, gdyby ktoś zadał pytanie, gdzie znajdują się obrazy, które oglądają widzowie, to wydaje się, że wszyscy, tak laicy, jak i filozofowie (niech mi wolno mieć tę nadzieję) odpowiedzieliby, że znajdują się na ekranach.

Nim przejdę dalej - dygresja. Opisana sytuacja jest banalna, a poczynione spostrzeżenia okazują się oczywiste. Nie wydaje się, aby filozofowie chcieli się nią zajmować. Sądzę jednak, że powinni. Niektóre filozoficzne niepokoje dotyczące percepcji dają się odtworzyć (bez utraty głębi) w tym prościutkim przypadku. Brzmią one nieco groteskowo, ale cóż można na to poradzić. Oto kilka przykładów.

Niepokój 1: Zgoda na to, że oprócz rozgrywanego gdzieś w RPA meczu istnieją obrazy meczu, to wielki filozoficzny błąd. Prowadzi on do zwielokrotnienia rzeczywistości. Gdybyśmy go popełnili, to musielibyśmy przyjąć, że każdy widz ogląda swój własny prywatny mecz, do którego inni nie mają dostępu itd., itd.

Niepokój 2: Byt zwany tutaj obrazem meczu jest nie do zaakceptowania. Jest on zaś nie do zaakceptowania z następującego względu. Wyobraźmy sobie np., że sędzia sędziujący rozgrywany właśnie (gdzieś w RPA) mecz ma pstrokatą koszulkę. Liczba plam na koszulce sędziego jest z pewnością ściśle określona. Liczba plam na oglądanym właśnie obrazie sędziego nie jest określona. Jakże można w ogóle postulować istnienie obiektu (chodzi o obraz koszulki sędziego, pojawiający się na ekranie), który jest plamisty, który posiada skończoną liczbę plam, ale liczba tych plam nie daje się określić. Byt taki musi z konieczności być urojeniem itd., itd. 
Nie p o kój 3: Nie jest możliwe oglądanie barwnych obrazów na ekranie telewizora, bo sygnały, które docierają do urządzenia nie są barwne, a w telewizorze nie ma malarza z farbami, który rozkodowywałby te sygnały i malował na użytek patrzącego barwny obraz. Myślenie takie jest myśleniem magicznym itd., itd.

Listę niepokojów można byłoby znacznie wydłużyć, nie będziemy jednak tego robić. Posiadający przygotowanie filozoficzne czytelnik spostrzegł już zapewne, że są one wzorowane na materialistycznej (naturalistycznej) krytyce kartezjanizmu. W szczególności na tej jego części, która zakłada istnienie pośrednika-obrazu w umyśle. Obraz w niematerialnym umyśle jest nie do przyjęcia, gdyż umysłu po prostu nie ma. Obraz w mózgu jest też nie do przyjęcia, bo nikt nigdy nie znalazł w mózgu żadnego barwnego obrazu. Wynika stąd, że obraz jako pośrednik, czy to w umyśle, czy to w obrębie organizmu, jest nie do przyjęcia. Nim przejdziemy do kolejnego etapu, chciałbym sformułować proste pytanie adresowane do potencjalnego czytelnika - filozofa naturalisty, a mianowicie:

\section{Czy barwny obraz na ekranie (telewizora, komputera itd.) jest do przy- jęcia?}

Muszę przyznać, że uważam to pytanie za retoryczne. Każdy przecież wie, że oglądamy barwne obrazy na naszych ekranach i że bardzo często reprezentują one (tak jak w rozważanym przykładzie) coś innego. Pośredniczą pomiędzy rzeczywistym światem a poznającym podmiotem.

No i co z tego? - mógłby rzec mój wyimaginowany filozof-naturalista. Przecież wszyscy (tzn. wszyscy należący do cechu; tzn. my - analityczni filozofowie umysłu) wiemy, że prawdziwy problem leży gdzie indziej. Owszem, widujemy obrazy czy to w muzeach, czy to na ekranach i obrazy te reprezentują często coś innego. Wszystkie te obrazy są jednak publiczne, tzn. wszyscy mają do nich ten sam dostęp. Stanowią one część dostępnego wszystkim materialnego świata. Prawdziwy problem, tzw. problem qualiów, polega na wyjaśnieniu, jak to się dzieje, że je widzimy. Wyjaśnienie kartezjańskie - czy to w jego mocnej wersji, a mianowicie, że w niematerialnym umyśle powstaje obraz (do którego nikt nie ma dostępu) widzianego obiektu; czy to w jego wersji słabszej, że obraz powstaje jakoś w mózgu (do którego też nikt nie ma dostępu) - jest nie do przyjęcia. Są to wyjaśnienia magiczne. Niematerialnego umysłu nie ma, a w materialnym ciele człowieka oglądającego barwne obiekty - w mózgu czy poza nim; w obrębie skóry - nikt nie znajduje żadnych obrazów.

Okazuje się, że barwny obraz, reprezentujący coś innego, może się znajdować wszędzie, byleby nie wewnątrz systemu poznawczego. I cóż począć z takim dictum? Nie pozostaje mi nic innego, jak przejść do drugiego etapu. 


\subsection{Etap drugi}

Kluczowym elementem etapu drugiego będzie eksperyment myślowy. Eksperyment myślowy, który przedstawię, można byłoby określić mianem inżynierskich. Z czasem wyjaśni się, co to znaczy.

\section{Prosty eksperyment myślowy, czyli o tym, co się przydarzyło Stefanowi}

Niech naszym głównym bohaterem będzie pan o imieniu Stefan. W momencie, gdy rozpoczyna się nasza opowieść, Stefan jest zupełnie zdrów. W szczególności, jego aparat wzrokowy jest całkowicie sprawny i działa bez zarzutu. Tak więc Stefan widzi i mówi (jeśli przyjdzie mu na to ochota), że trawa jest zielona, bezchmurne niebo błękitne, dojrzałe pomidory czerwone, śnieg biały, a smoła czarna itd., itd. To, co odróżnia Stefana od innych ludzi, to okoliczność, że o wiele częściej i chętniej niż inni korzysta ze swego laptopa. Otóż Stefan nie rozstaje się z tym pożytecznym artefaktem i, co więcej, nie wyłącza go ani na chwilę. Podczas gdy inni, czy to w lesie czy na spływie kajakowym, czy po prostu na przechadzce wolą rozglądać się wokół siebie, Stefan woli wpatrywać się w ekran.

Jeżeli niektórzy młodzi filozofowie nie widzą w zachowaniu Stefana nic nadzwyczajnego, to tym lepiej dla autora tego rozdziału.

Obyczaje Stefana miewają jednak swoje uciążliwości. Zdarza się, że Stefan wpada na drzewa, wchodzi do wody lub tylko dzięki przytomności i refleksowi kierowcy cudem unika kolizji z rozpędzonym samochodem. Toteż nasz bohater, idąc za radą przyjaciół, instaluje w swoim laptopie kamerę, która wprost na ekran przekazuje obraz najbliższego otoczenia. Ma to oczywiste zalety. Stefan (dzięki kamerze) wie, gdzie się znajduje i jakie obiekty go otaczają, a zarazem może robić to, co lubi najbardziej, czyli wpatrywać się w ekran.

Wydaje mi się, że to co napisałem do tej pory jest całkowicie jasne i nie powinno prowadzić do nieporozumień. Dla uzyskania całkowitej pewności w kluczowych kwestiach posłużmy się jednak prostym przykładem. Załóżmy, że Stefan wraz z przyjaciółmi znajduje się właśnie w ogrodzie zoologicznym i że wszyscy oglądają akurat pawia. Stefan ma włączoną kamerę i też ogląda pawia, ale ogląda go na ekranie swego laptopa. Otóż, gwoli uzyskania całkowitej pewności, Stefan ogląda pawia, ale ogląda go za pośrednictwem obrazu, który powstaje na ekranie jego laptopa. Sądzę, że na tę prostą konstatację muszą się zgodzić wszyscy; również filozofowie; a wśród filozofów również zwolennicy reprezentacyjnej teorii qualiów oraz dyzjunktywiści. Powtórzmy jeszcze raz. Stefan ogląda pawia za pośrednictwem obrazu na ekranie swego laptopa. Używając bardziej filozoficznego języka, moglibyśmy powiedzieć, że Stefan ma bezpośredni dostęp tylko do obrazu pawia na ekranie laptopa. Oczywiście Stefan mógłby spojrzeć na pawia i zrezygnować z pośrednictwa ekranu, ale dopóki tego nie zrobi, ma dostęp tylko do obrazu. To samo, oczywiście, dotyczy również tzw. qualiów; tzn. qualia, do których Stefan ma bezpośredni dostęp, oglądając pawia, też znajdują się na ekranie laptopa. 
Załóżmy teraz, że stan oczu Stefana zaczyna się gwałtownie pogarszać. Pogarsza się jednak w dość osobliwy sposób. Otóż Stefan coraz gorzej widzi obiekty w tzw. realu. Jeżeli natomiast korzysta z pośrednictwa ekranu laptopa, to, co prawda, widzi również gorzej, ale dzięki długotrwałej praktyce oglądania świata właśnie w ten sposób pogorszenie widzenia jest o wiele mniej dotkliwe. Co więcej, okazuje się, że fizyczne właściwości ekranu Stefanowego laptopa można zmienić w taki sposób (skorzystajmy z przywileju przysługującego filozofom pisującym takie teksty i pomińmy szczegóły), że nasz bohater widzi równie dobrze, jak na początku. Dodajmy, że zmiana fizycznych własności ekranu laptopa jest na tyle głęboka, że inni ludzie, spoglądając na ekran, z którego pośrednictwa korzysta Stefan, widzą bardzo kiepsko i z trudem identyfikują oraz rozpoznają obiekty. Przyjmijmy dalej, że stan oczu Stefana w dalszym ciągu systematycznie się pogarsza i wreszcie... Stefan w tzw. realu po prostu nic nie widzi. Na szczęście jest jeszcze laptop i jego ekran. Otóż, sztab specjalistów od widzenia, laptopów i ekranów jest w stanie zmienić jego właściwości w taki sposób i tak przystosować go do potrzeb Stefana, że nasz bohater, spoglądając na ekran, widzi równie dobrze, jak wówczas, gdy rozpoczynała się nasza opowieść. Tym razem fizyczne zmiany, którym poddano ekran laptopa są na tyle istotne, że inni ludzie, spoglądając na Stefanowy ekran, nic nie widzą; tzn. widzą ekran, ale nie widzą na nim żadnych obrazów. Nim ruszymy dalej z naszą opowieścią, zatrzymajmy się na chwilę na obecnym etapie i przypomnijmy rzeczy oczywiste.

Przyjmijmy, że Stefan wraz z przyjaciółmi ponownie wybrał się do ogrodu zoologicznego i że wszyscy oglądają akurat pawia. Stefan ma włączoną kamerę i też ogląda pawia, ale ogląda go na ekranie swego laptopa. Otóż, gwoli uzyskania całkowitej pewności, Stefan ogląda pawia, ale ogląda go za pośrednictwem obrazu, który powstaje na ekranie jego laptopa. Sytuacja jest o tyle nowa w stosunku do opisanej poprzednio, że tym razem Stefan posiada uprzywilejowany dostęp do obrazu, który powstaje na ekranie jego laptopa w mocnym, kartezjańskim znaczeniu. Poprzednio, każdy, jeśli zechciał, mógł spojrzeć na ekran i widział tam taki sam obraz, jaki widział Stefan. Tym razem jest inaczej. Obraz widzi tylko Stefan. Gwoli uniknięcia nieporozumień opiszmy to bardzo dokładnie. Otóż, laptop i jego ekran są obiektami publicznymi i wszyscy mają do nich dostęp. Inaczej sprawy się mają z obrazem. Do obrazu znajdującego się na ekranie ma dostęp tylko Stefan, tylko on (i nikt inny) widzi na nim obraz pawia. Podkreślmy to mocno: Stefan widzi obraz pawia, a nie pawia! Nie sposób przecież pomylić obrazu pawia, który znajduje się na ekranie laptopa, z pawiem. Oczywiście obraz pawia reprezentuje pawia, ale Stefan ma dostęp tylko do jego obrazu. I nie ma w tym przecież żadnej magii!, ani niczego co obrażałoby zdrowy rozsądek lub podważało filozoficzne analizy. Historia Stefana jest przecież całkiem zwyczajna, w tym sensie, że w naszym stechnicyzowanym świecie mogłaby się łatwo wydarzyć.

Oczywiście, Stefan nie rozstaje się już teraz ze swym artefaktem, który umożliwia mu „wzrokowy” kontakt ze światem, tyle że wyłącznie za pośrednictwem obrazów powstających na ekranie. Załóżmy ponadto, że specjaliści od takich przypadków jak Stefana, aby ułatwić mu życie łączą na stałe laptopa, wraz z innymi niezbędnymi artefaktami, z ciałem Stefana i miniaturyzują ekran, na którym Stefan zwykł oglądać ruchome obrazy reprezentujące zdarzenia w świecie. Przyj- 
mijmy dalej, że z czasem odpowiedni specjaliści, doskonaląc całą tę aparaturę, łączą ją z ciałem Stefana w taki sposób, że Stefan może uruchamiać ją i wyłączać bez udziału rąk, posługując się tzw. myślą lub (jeśli kogoś razi słowo „myśl”) aktywnością odpowiednich neuronów. Pierwszą rzeczą, którą Stefan robi po położeniu się do łóżka na nocny wypoczynek, jest wyłączenie aparatury za pomocą neuronów, a pierwszą, którą robi po przebudzeniu - uruchomienie aparatury za pośrednictwem neuronów. Stefan nie zdejmuje na noc aparatury, gdyż na obecnym etapie jest ona niezdejmowalna. Aby odłączyć ją (fizycznie) od ciała Stefana, trzeba by przeprowadzić długą i skomplikowaną operację, którą musieliby wykonać jacyś inżyniero-neurochirurdzy. Czy teraz można już uznać, że Stefan wraz $z$ całą aparaturą tworzą jeden system poznawczy? Sądzę, że tak. Proponujemy też, aby system poznawczy, który powstał w dalszym ciągu nazywać Stefanem. Dominacja "niegdysiejszego Stefana” w całym tym systemie jest bezsporna i nikt ze znajomych i przyjaciół Stefana nie ma żadnych wątpliwości co do tego, że osoba (lub obiekt, jeśli kto woli), to w dalszym ciągu Stefan. Cóż jednak z tego wszystkiego wynika? Kilka różnych rzeczy, które pozwolę sobie wypunktować, gdyż łącznie składają się one na antypodę współczesnych filozoficznych spekulacji dotyczących spostrzegania wzrokowego i qualiów. Otóż:

(1) Stefan spostrzega świat za pośrednictwem obrazów, które powstają na zminiaturyzowanym ekranie.

(2) Stefan ma uprzywilejowany dostęp do obrazów, które powstają na zminiaturyzowanym ekranie.

(3) Obrazy znajdują się na ekranie, a ten stanowi integralną część (rozszerzonego w opisany powyżej sposób) Stefana.

Choć wszystkie trzy konstatacje wydają się oczywiste, pozwolę je sobie skomentować oraz uprzedzić niektóre ewentualne zarzuty i nieporozumienia. Rozpocznijmy od (3). Otóż, formułując punkt (3), odczuwałem niejaką pokusę, aby napisać, że obrazy znajdują się $w$ umyśle Stefana. Uznałem jednak, że byłoby to zbyt kontrowersyjne; obrazy i uprzywilejowany dostęp stanowią już wystarczająco trudną pigułkę do przełknięcia. W punkcie (3) posłużyłem się dziwacznym określeniem rozszerzony Stefan. Zamiast tego określenia można byłoby zapewne użyć innych, np. rozszerzony aparat percepcyjny Stefana. To ostatnie określenie za bardzo jednak kojarzy się z lornetkami, mikroskopami itd., a takich skojarzeń chciałem właśnie uniknąć. Ekran, na którym Stefan ogląda obrazy reprezentujące świat, jest jego jedynym (a nie alternatywnym czy udoskonalonym) sposobem „wzrokowej” percepcji. Stefan pozbawiony ekranu nie widzi literalnie nic. Nim zakończę komentowanie tego punktu, kilka dalszych uwag. Mam niejasne przeczucie, że niektórzy zaprawieni w wynajdywaniu argumentów eksperci od filozoficznych analiz mogliby chcieć opisać casus Stefana w (mniej więcej) następujący sposób: Stefan ogląda tylko obrazy na ekranie, a te niczego nie reprezentują. Odrzucam tę opcję jako absurdalną. Wyobraźmy sobie, że Stefan wybrał się na stadion i ogląda wraz z przyjaciółmi mecz piłki nożnej. Obrazy, które widzi na swym ekranie w oczywisty sposób reprezentują wydarzenia na boisku. 
Przejdźmy do punktu (1). Chociaż to, że Stefan widzi obrazy na specjalnie dla niego spreparowanym ekranie (a nie bezpośrednio) wydaje mi się oczywiste, to jednak chciałbym tej kwestii poświęcić nieco uwagi, a to dlatego, że w filozofii percepcji dzieją się ostatnio rzeczy bardzo dziwne. Istnieją np. filozofowie, którzy skłonni są utrzymywać, że w przypadku tzw. perfekcyjnie spreparowanej halucynacji (niczym się nie różniącej dla doznającego jej podmiotu od rzeczywistości) doznający - przedmiot halucynacji - jest czystą nicością, a w mózgu istnieją tylko byty reprezentujące ową czystą nicość. Inni znowu filozofowie skłonni są utrzymywać, że perfekcyjna halucynacja (choć podmiot nie odróżnia jej od rzeczywistości) jest czymś zasadniczo innym niż tzw. werydyczna percepcja. Otóż upieramy się przy tym, że percepcja Stefana jest w zasadniczym rdzeniu werydyczna, ale oglądana nie bezpośrednio, tylko na ekranie. Jeżeli ktoś byłby skłonny uznać, że Stefan podlega konsekwentnej halucynacji i że w związku z tym nic nie widzi, to musiałby również uznać, że ludzie oglądający mecz piłki nożnej za pośrednictwem telewizji, ale na żywo, też nic nie widzą. Jeżeli natomiast ktoś chciałby uznać, że Stefan spostrzega (wbrew oczywistości, ale w filozofii nie takie rzeczy się zdarzały) jednak bezpośrednio, a nie za pośrednictwem ekranu, to musiałby uznać, że nie zachodzi żadna różnica pomiędzy ludźmi oglądającymi mecz na stadionie a ludźmi oglądającymi ten sam mecz na żywo, ale w telewizji, czyli za pośrednictwem ekranu.

Przejdźmy z kolei do punktu (2). Odwoływanie się do tzw. uprzywilejowanego dostępu uchodzi we współczesnej filozofii umysłu, zdominowanej przez naturalizm, nieomal za rodzaj czarnej magii. Zgoda na istnienie uprzywilejowanego dostępu do własnych myśli, qualiów, obrazów, wyobrażeń miałaby rzekomo oznaczać zgodę na istnienie niematerialnego umysłu, a ten jest rzekomo nie do przyjęcia. Muszę przyznać, że oba te przeświadczenia wydają mi się mocno „rzekome". Nie będę się jednak zajmować tymi wszystkimi rzekomościami. Nie to jest przedmiotem tego rozdziału. I tak już jest on zbyt skomplikowany. Twierdząc, że Stefan ma uprzywilejowany dostęp do obrazów powstających na zminiaturyzowanym ekranie, nie uprawiam ani czarnej, ani białej, ani żadnej innej magii. Chodzi po prostu o to, że żaden inny człowiek, spoglądając na zminiaturyzowany ekran Stefana, nie widzi na nim obrazu. Stefan i tylko Stefan widzi na nim obrazy. Moglibyśmy (idąc śladem XVIII-wiecznego filozofa) powiększyć ekran do rozmiarów młyna (albo jeszcze bardziej) i nikt nie dostrzegłby tam żadnego obrazu, a Stefan je tam widzi i na tym polega jego uprzywilejowany dostęp.

A co by się stało, gdyby komuś innemu, powiedzmy Marii, „wmontowano” całą tę aparaturę w taki sam sposób jak Stefanowi? Czy Maria widziałaby to, co Stefan? Nie! Maria nic by nie widziała. Rzeczona aparatura (a w szczególności ekran) jest silnie zindywidualizowana i dostosowana do wybiórczych potrzeb Stefana. Gdyby aparat wzrokowy Marii pogarszał się w analogiczny sposób jak aparat wzrokowy Stefana; gdyby przeszła ona analogiczny trening; gdyby stopniowo przystosowywano ekran do potrzeb Marii itd., itd., to wtedy Maria widziałaby mniej więcej to, co Stefan. Tak więc ani Maria, ani nikt inny, przed wmontowaniem czy po wmontowaniu aparatury, nie widzi na ekranie żadnych obrazów. Widzi je tam tylko Stefan. Nie potrafię tego opisać inaczej i lepiej, jak właśnie tak, że Stefan ma uprzywilejowany dostęp do obrazów, które znajdują się (powstają) na ekranie. 
Ależ to przecież jakiś neokartezjanizm?! - mógłby się oburzyć naturalista. Mamy tutaj obrazy i uprzywilejowany dostęp do nich, a na dodatek obrazy reprezentujące świat znajdują się wewnątrz systemu poznawczego. Brakuje tylko niematerialnego umysłu?! Wszystko to prawda i podzielam oburzenie naturalisty. Cóż jednak zrobić. Tak jakoś wyszło. A poza tym wolę nazywać stanowisko, którego bronię aktywnym internalizmem. Końcową część pracy chciałbym poświęcić promocji aktywnego internalizmu. Uważam, że jest to stanowisko, które ma przed sobą piękną przyszłość.

\section{Aktywny internalizm}

\subsection{Pochodzenie nazwy}

Wyjaśnijmy wpierw genezę proponowanego określenia. W tym celu powołajmy się na artykuł napisany przez dwóch znanych i cenionych filozofów. Wsparcie znanych i cenionych bardzo się nam przyda, a poza tym osadzi tę książkę w pewnej szerszej perspektywie.

W pracy TheExtended Mind Andy Clark i David Chalmers (Clark A i Chalmers D 1998) rozważają (fikcyjny) przypadek człowieka o imieniu Otto, który choruje na chorobę Alzheimera i w związku z tym nie rozstaje się ze swoim notatnikiem, w którym zapisuje różne informacje. Autorzy starają się przekonać czytelnika, że o ile spełnione są pewne warunki, o tyle notatnik należy traktować jako pełnoprawną część umysłu Otta. W notatniku - argumentują - znajduje się w końcu wiele różnych przekonań Otta, do których ma on nieco inny (choć wcale nie gorszy) dostęp niż do przekonań, które znajdują się gdzieś w mózgu. Dodajmy, że autorzy określają swoje stanowisko mianem aktywnego eksternalizmu, aby odróżnić je od tradycyjnego eksternalizmu, zapoczątkowanego opowieścią Hilary'ego Putnama o Ziemi i Ziemi Bliźniaczej (Putman 1975). Najszybciej i najkrócej różnicę zachodzącą pomiędzy obydwoma eksternalizmami można wyjaśnić w sposób następujący. Wedle zwolenników tradycyjnego eksternalizmu znaczenia wielu terminów (eksternalizm semantyczny) oraz treści wielu postaw propozycjonalnych (eksternalizm propozycjonalny) są współdeterminowane przez środowisko społeczne i środowisko przyrodnicze; wedle zwolenników aktywnego eksternalizmu, niektóre elementy środowiska (np. notatniki, laptopy itd.) w pewnych okolicznościach można uznać za integralną część umysłów korzystających z nich ludzi. Oba eksternalizmy nie są, rzecz jasna, sprzeczne. Po prostu kładą nacisk na różne czynniki. Tak więc można zarazem sądzić, że postawy propozycjonalne odnoszące się na przykład do wody są współdeterminowane przez środowisko społeczne i przyrodnicze oraz być przeświadczonym (tak jak podobno jest o tym przeświadczony Chalmers), że mój telefon komórkowy jest integralną częścią mojego umysłu. 
Określenie aktywny eksternalizm na opisanie stanowiska omówionego w poprzednim akapicie wydaje się nam mylące. Jeżeli ktoś sądzi, że jego umysł tworzy w pewnych określonych warunkach prawdziwą jedność z jakimś artefaktem, to, jak się wydaje, określenie aktywny internalizm byłoby bardziej właściwe. Oczywiście każdy proponuje takie określenia, jakie uważa za najlepsze i w żadnym razie nie zamierzamy pouczać autorów The Extended Mind. Zachowajmy zatem określenie aktywny eksternalizm, pamiętając o tym, że dotyczy ono przekonań. Na opisanie naszego pomysłu proponujemy jednak określenie aktywny internalizm. Ponieważ nasza propozycja dotyczy qualiów i obrazów (a nie przekonań), nie powinno to prowadzić do nieporozumień.

\subsection{Promocja aktywnego internalizmu}

Promocję aktywnego internalizmu sprowadzam do przedstawienia racji, które skłoniły mnie do sformułowania i obrony tego stanowiska. Skoro mnie przekonały, być może potrafią przekonać również innych. Jest ich kilka i zaprezentuję je w osobnych akapitach.

Racja pierwsza (i chyba najważniejsza) - to współczesne pomysły naturalistów dotyczące qualiów, a w szczególności tzw. reprezentacyjna teoria qualiów i tzw. dyzjunktywizm. Teorie te (czy też koncepcje) są skrajnie nieintuicyjne i obfitują w dziwactwa, których piszący niniejsze nie jest w stanie przełknąć.

Racja druga jest taka, że główną przyczyną dziwactw współczesnych filozofów pisujących na temat qualiów jest ich silne przeświadczenie, że nic z tego, co tradycyjnie (i przez wiele set lat) umieszczano po stronie podmiotu nie może się tam żadną miarą znaleźć. Rozumuje się wedle schematu: Skoro niematerialnego umysłu nie ma, to po stronie tzw. poznającego podmiotu (zwanego często systemem poznawczym) znajduje się tylko to, co znajduje się w granicach skóry. A w granicach skóry znajduje się wiele różnych rzeczy, w tym rzecz najważniejsza, a mianowicie mózg, ale w żadnej z tych rzeczy, a w szczególności w mózgu, nie można odnaleźć bytów, które tradycyjnie zwano jakościami zmysłowymi lub datami wrażeniowymi lub jeszcze jakoś inaczej, a które dzisiaj zwie się qualiami $i$ które to byty przez wiele set lat filozofowie umieszczali w niematerialnym umyśle. W szczególności - rozumuje się - absurdalne byłoby mniemanie, że gdzieś w obrębie systemu poznawczego, ciągle jeszcze zwanego człowiekiem, powstają barwne obrazy (gdzież one miałyby się znajdować, chyba w mózgu; ale przecież to śmieszne!), które poznający podmiot mógłby sobie oglądać. Takie myślenie to myślenie w kategoriach kartezjańskiego teatru (określenie wymyślone przez Dennetta (Dennett 1991), w kategoriach, które dawno się zdezaktualizowały i które są nie do przyjęcia w świetle współczesnej wiedzy itd., itd. (Otóż, gdy czyta się ciągle takie rzeczy oczywiste oczywistości, to nabrzmiewa uczucie sprzeciwu. A gdyby tak udało się pokazać, że jednak..., mimo wszystko... W jaki sposób tego dokonać? Powoływanie się na doznania i pierwszoosobowe 
doświadczenie to zamierzchła przeszłość i kartezjański ciemnogród. Trzeba byłoby czegoś zupełnie innego, nowego... I w ten sposób pojawiła się kolejna racja)

Racja trzecia daje się streścić mniej więcej tak. Nikt przecież nie zaprzeczy, że na ekranach (telewizorów, komputerów itd.) nieustannie widujemy barwne obrazy i że obrazy te często (w czasie tzw. transmisji na żywo) reprezentują świat zewnętrzny. Gdyby zatem udało się owe obrazy pojawiające się na ekranach uczynić integralnym elementem pewnego systemu poznawczego (resp. pewnego człowieka), to otrzymalibyśmy kartezjański ciemnogród w najbardziej klasycznym wydaniu: Świat byłby spostrzegany za pośrednictwem obrazów, a obrazy znajdowałyby się wewnątrz systemu poznawczego. Byłby to zarazem taki ciemnogród, któremu bardzo trudno byłoby zaprzeczyć. Jak jednak tego dokonać? I tutaj z pomocą przyszły mi dwie rzeczy, a mianowicie dominująca we współczesnej filozofii umysłu ideologia, czyli funkcjonalizm, oraz Clark i Chalmers z pomysłem przedstawionym w The Extended Mind. Łącznie złożyło się to na kolejną rację.

Racja czwarta, jako się rzekło w poprzednim akapicie, wspiera się na dwóch filarach. Pierwszym jest funkcjonalizm. O funkcjonalizmie i różnych jego odmianach pisze się grube książki. Na szczęście to, co dla nas tutaj istotne, a mianowicie główna idea funkcjonalizmu, daje się streścić krótko. Przedstawiliśmy ją już w rozdziale 3. Jest ona dla nas tak ważna, że powtórzymy ją tutaj oraz poszerzymy o nowe elementy. A oto ona.

\section{Narracja funkcjonalisty}

Człowiek jest maszyną i, co za tym idzie, składa się, podobnie jak inne maszyny (rower, pralka automatyczna czy komputer) z mniejszych części oraz posiada (znowu podobnie jak inne maszyny) wejście i wyjście. Wyjaśnijmy od razu, że w przypadku człowieka wejście to powierzchnia skóry, poprzez którą przedostają się bodźce do jej wnętrza z tzw. środowiska, a na wyjściu człowiek wytwarza zachowanie; gdyż każda maszyna coś robi; pralka automatyczna pierze, samochód jedzie, a człowiek - jakoś się zachowuje. Mniejsze części, z których składa się człowiek, pełnią (podobnie jak w innych maszynach) określone funkcje (tzn. wpływają w całkiem określony sposób na funkcjonowanie innych części i w efekcie na zachowanie całej maszyny). Wynika stąd, że człowieka można rozebrać (podobnie jak inne maszyny) na mniejsze części (co akurat nie jest trudne) i ponownie złożyć (co jest łatwe w przypadku rowerów, pralek automatycznych i komputerów, ale nikomu jeszcze nie udała się taka sztuka w przypadku ludzi czy choćby biedronek; czym nie należy się przejmować, gdyż piszemy o tym, co w zasadzie wykonalne, a nie o tym, co tu i teraz potrafimy zrobić) i w efekcie otrzymamy tę samą (a przynajmniej taką samą) maszynę, a w każdym razie maszynę, która zachowuje się dokładnie tak samo, co w przypadku maszyn jest w końcu najważniejsze. Z "maszynowości” człowieka wynika ponadto słynna zasada wielość realizacji. Otóż, jeżeli człowiek jest maszyną i składa się z mniejszych części pełniących określone funkcje, to - cóż to szkodzi - jeśli jedną z tych mniejszych części (której funkcje wcześniej dokładnie 
poznaliśmy) wymontujemy i na jej miejsce wmontujemy nową i inną pod względem fizycznym (np. cięższą, Iżejszą, o innym składzie chemicznym; co kto lubi) część, pełniącą dokładnie te same funkcje. Maszyna nie dozna przez to żadnego szwanku, a jej funkcjonowanie (jeśli stara część była zużyta lub uległa uszkodzeniu) może się nawet poprawić. Rzecz jasna, to, co można zrobić z jedną częścią, można zrobić z wieloma, a wreszcie ze wszystkimi; najlepiej zrobić to po kolei, żeby system poznawczy się nie wystraszył. Otrzymamy w ten sposób tę samą (a przynajmniej taką samą) maszynę, choć inaczej fizycznie zrealizowaną; cięższą, Iżejszą; o innym składzie chemicznym itd., itd. O słuszności prezentowanego podejścia w przypadku takich maszyn jak rowery, pralki automatyczne, samochody czy komputery nie trzeba nikogo przekonywać, gdyż nieomal każdy wymieniał w rzeczonych maszynach jakieś zużyte części na nowsze, często inne pod względem fizycznym, a funkcjonowanie maszyny tylko się dzięki temu poprawiało. W przypadku maszyn zwanych tradycyjnie ludźmi wskazana jest ostrożność, ale - jeśli odrzucimy przesądy - to powinna to być ostrożność podyktowana tylko niedostatecznym (jeszcze) stanem wiedzy. Funkcje wielu narządów (czyli części) są skomplikowane, a ich pełne poznanie nie jest proste. Wszelako nawet w przypadku maszyn tak skomplikowanych jak ludzie trudno wątpić $w$ trafność prezentowanych założeń. Odwołajmy się znowu do praktyki. Są już sztuczne serca, sztuczne nerki, sztuczne woreczki żółciowe i żołądki, a utracone w wyniku wypadków ręce zastępuje się artefaktami, którymi pacjenci sprawnie się posługują i w których posiadają zmysł dotyku; uczeni specjaliści pracują intensywnie nad sztucznym słuchem i wyprodukowanymi w fabryce oczami... Robocop jest nie tylko w zasięgu wyobraźni, ale leży w zasięgu techniczno-inżynierskich możliwości naszej cywilizacji. Jedną z części, której nie próbowano do tej pory wymieniać jest mózg, zwany dawniej siedliskiem duszy. Nie ulega jednak wątpliwości, że na przeszkodzie (po odrzuceniu przesądów) stoi tylko brak odpowiedniej wiedzy i piętrzące się trudności techniczne. W końcu mózg też jest maszyną, też składa się z mniejszych części i też coś robi. Cóż zatem stoi na przeszkodzie, aby - przynajmniej w wyobraźni - zastosować ogólne zasady do zbyt skomplikowanych (na razie) w praktyce przypadków. Czynią to w literaturze przedmiotu filozofowie-funkcjonaliści, wymieniając w starannie zaplanowanych eksperymentach myślowych różne elementy mózgu (są to, na ogół, neurony) na różne inne obiekty; niekiedy są to artefakty (najczęściej chipy); niekiedy małe ludziki; a niekiedy Chińczycy. W końcu nie jest ważne, czym są te obiekty, ważne jest to, aby pełniły te same funkcje, które pełniły neurony itd., itd. W każdym razie, jeżeli funkcjonalizm jest prawdziwy (a przecież jest), to pełna realizacja człowieka w innym (niż biologiczne) tworzywie też jest (w zasadzie) możliwa. A jeśli tak, to puśćmy wodze fantazji i przenieśmy się na chwilę w (niedaleką, być może) przyszłość. Ludzie prędzej lub później porzucą „biologiczne skorupy” i, jeśli można się tak wyrazić, „przeprowadzą się”. Nowe, lepsze, trwalsze ciała... itd., itd.

Przerwijmy na chwilę narrację funkcjonalisty. Czy jest ona prawdziwa? Długo by o tym pisać. Dla nas ważne jest to, że jest to narracja dominująca. Mam wrażenie, że nie tylko filozofowie-funkcjonaliści myślą w ten sposób, ale i wielu (zwłaszcza tych młodych) laików. Wykorzystajmy tę okoliczność dla promocji ak- 
tywnego internalizmu. W promocjach najważniejsze jest w końcu to, aby znaleźć się w głównym nurcie i wymyślić chwytliwą nazwę. Nie znaczy to, że zamierzam przekonywać do czegoś, w co sam nie wierzę. W dalszym ciągu będę korzystać z założeń funkcjonalizmu tylko w takim stopniu i w takiej mierze, w jakiej uważam je za trafne. Uzupełnijmy narrację funkcjonalisty o brakujący element.

\section{Ciag dalszy narracji funkcjonalisty}

Gdzie kończy się jedna maszyna, a zaczyna druga? Oto jest pytanie! Czy robotnik, sterujący dźwigiem, to jedna maszyna, a dźwig - to druga osobna maszyna? Z pewnością tak właśnie myślimy i są po temu ważne powody. Długo by je roztrząsać. Gdyby jednak pewien robotnik nie rozstawał się z dźwigiem, gdyby w ogóle nie opuszczał kabiny sterowniczej przez całe życie, gdyby się tam urodził... Z pewnością to wszystko za mało. Dźwig i robotnik to jednak dwa zupełnie odrębne byty. A gdyby połączono go trwale z dźwigiem i to w sposób niesłychanie intymny; gdyby mógł sterować dźwigiem, używając układu nerwowego (jest to możliwe w przypadku sztucznych rąk, a więc $i$ w przypadku dźwigów) i gdyby, na dodatek, chwytając stalowymi kleszczami różne obiekty, czuł, że one są twarde lub miękkie, szorstkie lub gładkie, ciężkie lub lekkie itd. (a ponieważ jest to możliwe w przypadku sztucznych rąk, więc zapewne i w przypadku dźwigów; rozmiary artefaktu, to w końcu szczegóły techniczne), to wtedy... moglibyśmy nabrać wątpliwości i powiedzieć, że robotnik został rozszerzony. Funkcjonalizm, to nie tylko przebudowa, ale również, a nawet przede wszystkim rozbudowa! A rozbudowa, to nic innego jak aktywny internalizm.

Maszyny, które budujemy, są coraz doskonalsze nie tylko w tym sensie, że wykonują coraz bardziej skomplikowane zadania i robią to coraz szybciej, lecz także w tym znaczeniu, że są łatwiejsze do obsługiwania i coraz bardziej sprzężone z użytkownikiem. Użytkownicy spędzają coraz więcej czasu przy swych maszynach i nie rozstają się z nimi nawet po godzinach pracy (a niektórzy nawet w czasie snu). Większość maszyn obsługuje się, korzystając z pośrednictwa rąk i nóg, a ich działanie jest kontrolowane przez użytkowników na... ekranach. Cóż takiego nadzwyczajnego by się stało, gdyby kontakt ze światem odbywał się wyłącznie za pośrednictwem ekranu? Przecież i tak wielu (młodych) ludzi przez większość czasu wpatruje się w ekran. Ekran to ich naturalne „wzrokowe środowisko". Zastąpienie tradycyjnego oglądu świata oglądaniem go za pośrednictwem ekranu zapewne wielu przyjęłoby z wdzięcznością. Oto jeden przykład: Znajoma poruszając się samochodem ze swym dwunastoletnim synem po Nowym Jorku, w pewnym momencie zaczęła go usilnie nakłaniać do tego, aby na chwilę oderwał oczy od ekranu i rozejrzał się wokół. „Po co? - odrzekł chłopiec. Ja to wszystko znacznie lepiej widzę na swoim ekranie!"

Piszę to wszystko, aby wesprzeć tezę, że przypadek Stefana jest bardzo zwyczajny, bardzo współczesny i mieści się w głównym nurcie funkcjonalistycznej ideologii. Ten zwyczajny przypadek ma jednak niezwyczajne filozoficzne konsekwencje. Skupmy się na nich raz jeszcze. 


\section{Przypadek Stefana a filozofia percepcji (oraz kilka różnych „ale”)}

Wypunktujmy jeszcze raz kluczowe okoliczności.

Po pierwsze, Stefan spostrzega świat za pośrednictwem obrazów, które znajdują się na ekranie laptopa.

Po drugie, Stefan ma do tych obrazów uprzywilejowany dostęp.

Po trzecie, obrazy znajdujące się na ekranie laptopa reprezentują świat zewnętrzny; są reprezentacjami, a nie rzeczami reprezentowanymi.

Po czwarte, ekran, na którym znajdują się obrazy, stanowi integralny element Stefana; wyrażając się bardziej dosadnie moglibyśmy powiedzieć, że stanowi on pełnoprawny element rozszerzonego Stefana; wyrażając się jeszcze dosadniej, moglibyśmy powiedzieć, że znajduje się w środku rozszerzonego Stefana.

Co z tego wszystkiego wynika? Otóż to, że w przypadku Stefana tzw. internalizm jest z pewnością prawdziwy i to prawdziwy w bardzo mocnym, kartezjańskim wydaniu: Obrazy znajdują się na ekranie, a ekran znajduję się wewnątrz rozszerzonego Stefana. Dawniejsi filozofowie powiedzieliby zapewne, że obrazy, które ogląda Stefan znajdują się w jego niematerialnym umyśle. My jesteśmy ostrożniejsi i mówimy, że obrazy, które ogląda Stefan znajdują się na ekranie, a ekran stanowi integralną część rozszerzonego Stefana. Stanowisko, którego bronimy nazwaliśmy aktywnym internalizmem. Sądzę jednak, że określenie neokartezjanizm byłoby równie trafne. Wszak mamy tutaj uprzywilejowany dostęp do obrazów, a te znajdują się wewnątrz systemu poznawczego i Stefan spostrzega świat tylko za pośrednictwem tych obrazów, do których jedynie ma bezpośredni dostęp. Zarazem stanowisko to mieści się w ramach szeroko rozumianego fizykalizmu, a mianowicie tzw. superwencyjnego fizykalizmu. Obrazy, które ogląda Stefan, w sposób oczywisty superweniują na fizycznych własnościach ekranu.

No dobrze, mógłby ktoś powiedzieć, ale cały dowcip z aktywnym internalizmem (resp. neokartezjanizmem) polega na tym, że pewien wycinek środowiska (w tym wypadku ekran), na którym normalni, tzn. nie-rozszerzeni ludzie oglądają obrazy, złącza się z pewnym człowiekiem tak ściśle, że zaczynają tworzyć jeden system. Tak, na tym polega cały dowcip. Fakt, że sztuczka jest prosta przemawia na jej korzyść; tym łatwiej ją przełknąć. To, co przytrafiło się Stefanowi może - mutatis mutandis - łatwo się przytrafić w naszym stechnicyzowanym świecie w rzeczywistości. Być może, w bliższej lub dalszej przyszłości wielu ludzi (być może wszyscy) będą oglądać świat za pośrednictwem odpowiednich ekranów. Rozszerzanie, czyli aktywny internalizm (resp. neokartezjanizm) ma przed sobą piękną przyszłość.

No dobrze, mógłby powiedzieć ktoś inny (tym razem prawdopodobnie filozof), ale przypadek Stefana wcale nie rozwiązuje problemu qualiów. Co najwyżej pokazuje, że można w ten sposób rozszerzyć pewnego człowieka, że nie będziemy mieli wątpliwości co do tego, że ów rozszerzony człowiek ogląda świat za 
pośrednictwem obrazów, które znajdują się na specjalnym ekranie. W dalszym ciągu jednak nie wiemy, jak powstają qualia i gdzie się znajdują. Otóż, gdzie znajdują się qualia (czy raczej ich skonkretyzowane egzemplarze), które widzi Stefan - to akurat wiemy. Znajdują się na ekranie. Natomiast rzeczywiście nie wiemy, jak to się dzieje, że Stefan je widzi. Zadaniem, jakiego się podjęliśmy w tym rozdziale nie było jednak roztrząsanie kwestii, jak to się dzieje, że Stefan w ogóle widzi coś na ekranie swego laptopa, tylko pokazanie, że w idei pośrednictwa przez obraz nie ma nic strasznego!

No dobrze, mógłby powiedzieć jeszcze ktoś inny (tym razem na pewno filozof), ale czy idea pośrednika nie doprowadzi nas do jakiegoś nowego sporu o istnienie świata? Załóżmy, że tak jak chce autor tego rozdziału, Stefan ma bezpośredni wzrokowy dostęp tylko do obrazu, który znajduje się na ekranie. Załóżmy dalej, że w wyniku postępu naukowo-technicznego, ekran ten (a wraz z nim obraz, który widzi Stefan) jest tak doskonalony, że to, co widzi Stefan nie różni się niczym od tego co widzą ci, którzy wykorzystują oczy i tylko oczy. Świat Stefana (czy raczej obraz świata), w odróżnieniu od świata normalnych ludzi, istniałby jednak tylko na ekranie. Załóżmy dalej (na próbę), że taki ekran instaluje się (w ramach postępu naukowo-technicznego) wszystkim ludziom (najlepiej tuż po urodzeniu i amputując przy okazji zbędne oczy). Otóż, gdyby do tego doszło, to przyjmując sposób myślenia autora tego rozdziału - należałoby przyjąć, że cała ludzkość żyje w świecie, który istnieje tylko na ekranach, a przynajmniej tylko do takiego świata ma wzrokowy dostęp. Należałoby wówczas przyjąć, że pomiędzy ludźmi a rzeczywistym światem pośredniczy sen i że ludzie mają dostęp tylko do snu. Sposób myślenia autora nieuchronnie prowadzi do dawno już przebrzmiałego sporu o istnienie świata i dlatego jest nie do przyjęcia. Konieczne jest jakieś inne rozwiązanie. Replika na tę obiekcję wydaje mi się na tyle ważna, że poświęcę jej kilka kolejnych akapitów.

Otóż nie jest potrzebne żadne nowe podejście. Gdy oglądam mecz piłki nożnej na żywo, siedząc przed telewizorem, to nie mam żadnych wątpliwości co do tego, że istnieją dwa zupełnie różne byty. Pierwszy to mecz, który stanowi część rzeczywistego świata i który jest rozgrywany wiele kilometrów od miejsca, gdzie siedzę, a drugi to obraz, który znajduje się na ekranie mego telewizora. Nie mam również żadnych wątpliwości co do tego, że obraz reprezentuje mecz i jest w znacznym stopniu do niego podobny. Idea pośrednika jest w tym wypadku w sposób samooczywisty trafna i nie prowadzi do żadnych nieporozumień i trudności. Nie bardzo rozumiem, jakie to nowe trudności mogłyby się pojawić, gdyby złączono ekran na stałe z moim ciałem, dostosowano do indywidualnych potrzeb (jak u Stefana) i sprawiono, że obraz (reprezentujący mecz) byłby tak sugestywny i realistyczny, że dorównywałby (a być może przewyższał) „realizmem” mecz oglądany za pośrednictwem oczu z trybun stadionu. Jeżeli telewizory nie doprowadziły do nowego sporu o istnienie świata, to dlaczego do takiego sporu mieliby doprowadzić ludzie poszerzeni o telewizory. Co to w końcu za różnica, gdzie znajdują się ekrany telewizorów?!

No dobrze, ale nie da się chyba zaprzeczyć, że to właśnie idea pośrednika idea, że pomiędzy rzeczywistym światem i poznającym podmiotem znajduje się 
obraz, który powstaje w niematerialnym umyśle i do którego ów umysł jedynie ma dostęp - doprowadziła do sporu o istnienie świata. Forsowane przez autora podejście (gdyby je zaakceptowano) musiałoby doprowadzić do kolejnego.

Otóż nie. Niegdysiejszy spór o istnienie świata wspierał się na dwóch filarach - śnie i Demonie. Oba te byty były wielce tajemnicze, a spór odbywał się w zupełnie innej sytuacji poznawczej. Obecnie, w naszym unaukowionym i stechnicyzowanym świecie, oba te byty znajdowałyby się pod naszą pełną kontrolą. Demonem byliby eksperci od ekranów, którzy w porozumieniu i w ścisłej współpracy z poznającym podmiotem mogliby dowolnie manipulować jakościowymi elementami obrazu. I o co tu się spierać w takiej sytuacji?

Załóżmy, że eksperci tak zmieniają właściwości Stefanowego ekranu, że obraz, który widzi Stefan jest taki, że trawa jest czerwona, niebo żółte itd., itd. Załóżmy dalej, że Stefan samodzielnie (za pomocą neuronów; patrz działanie neuronami) zmienia sobie kolor trawy. Klik (neuronami) i trawa zielona, klik i czerwona. Załóżmy dalej, że Stefan może sobie dowolnie ustalać kolor trawy: klik czerwona, klik niebieska, klik żółta itd. I o co tu się spierać? Wszak kolory w sposób oczywisty zależą od fizycznych własności ekranu (superweniują na fizyczne właściwości ekranu), który stanowi integralną część rozszerzonego Stefana.

No dobrze, ktoś mógłby powiedzieć na koniec: Niech już będzie, że neokartezjanizm (czy też aktywny internalizm, jak woli go nazywać autor) w stosunku do rozszerzonego Stefana jest prawdziwy. Ale przecież nie tak jest w przypadku normalnych ludzi. Stefan jest wyjątkowy. Spostrzeganie normalnych ludzi wymaga zupełnie innego podejścia. To, czy spostrzeganie wzrokowe normalnych ludzi wymaga zupełnie innego podejścia, wydaje mi się mocno wątpliwe. Nie będę jednak rozwijać tego wątku; a w każdym razie nie w tym rozdziale. Skupmy się na czymś innym. Otóż, wydaje mi się, że wielu filozofów sądzi, że idea pośredniczącego obrazu (pomiędzy podmiotem a światem) jest nie do przyjęcia z jakichś niezwykle ważnych i głębokich zarazem filozoficznych względów. Akceptacja idei pośrednika miałaby prowadzić do filozoficznej katastrofy. Zauważmy zatem, jak łatwo sprawić, że idea pośrednika staje się nie do odrzucenia. (Wszak Stefan na pewno ogląda świat za pośrednictwem obrazów). A jeżeli to jest takie łatwe, to owe filozoficzne względy nie są chyba ani takie ważne, ani takie głębokie.

Co się natomiast tyczy filozoficznych katastrof, to na szczęście są one najmniej groźne ze wszystkich znanych mi katastrof!

\section{Epilog}

Załóżmy, że rzecz się dzieje gdzieś w przyszłości i że przyszłość ta w interesującym nas zakresie wygląda mniej więcej tak: Każdy ludzki osobnik po przyjściu na świat przechodzi krótki i bezbolesny zabieg, polegający na usunięciu oczu i zastąpieniu ich odpowiednim zestawem artefaktów, zwanym w skrócie RP (rozszerzona percepcja). Dzięki RP ludzie widzą dalej, lepiej i więcej niż widzieli ich 
antenaci w zamierzchłych czasach za pomocą oczu. Oto kilka przykładów. Ludzie wyposażeni w RP, po uruchomieniu odpowiednich funkcji (oczywiście za pomocą neuronów, lub - jeśli kto woli - za pomocą swobodnych aktów woli), widzą wyraźnie obiekty oddalone o wiele kilometrów; po uruchomieniu innych jeszcze funkcji mogą je powiększać penetrując w zbliżeniu i powiększeniu najdrobniejsze szczegóły; a po uruchomieniu jeszcze innych funkcji (a wszystko to odbywa się tak łatwo i automatycznie jak zmrużenie oczu) widzą wnętrza ludzkich i zwierzęcych organizmów itd., itd. (długo by jeszcze można wymyślać). Jednym z ważnych elementów RP jest specjalny ekran, którego właściwości można odruchowo zmieniać i na którym ogląda się (oczywiście w trzech wymiarach) obrazy świata zewnętrznego. Co do tego nikt nie ma wątpliwości! To właśnie na ekranie powiększa się, przybliża, oddala, a również przekręca (bo jest i taka funkcja) obrazy różnych obiektów. Jedną z funkcji jest wybór kolorów. Świat można oglądać w takich kolorach, jakie się akurat wybierze. Nauka nazw kolorów odbywa się we wczesnym dzieciństwie i oczywiście za pośrednictwem ekranu. Czy w tych warunkach tzw. reprezentacyjny eksternalizm w kwestii kolorów byłby w ogóle jeszcze możliwy?

Załóżmy, że Jacek i Agatka chodzą do przedszkola i że opanowali już nazwy kolorów, ale mają jeszcze kłopoty z pełnym wykorzystaniem możliwości RP. Załóżmy dalej, że dzieci są akurat w parku i oglądają trawę. Trawa jest żółta - zauważa Jacek; nieprawda - czerwona, upiera się Agatka. W spór wkracza nauczycielka. Kochane dzieci, to jakiego koloru jest trawa zależy wyłącznie od was! Jeżeli zrobicie to a to, to trawa jest czerwona, a teraz, spójrzcie żółta, a teraz - pomarańczowa. A teraz nieco historii. Dawno, dawno temu nasi praprzodkowie, którzy nie umieli się jeszcze ani przebudowywać, ani rozszerzać, mogli oglądać trawę tylko w jednym kolorze. Chcecie się dowiedzieć jakim? Kliknijcie (neuronami) na tę ikonkę. O właśnie w takim. Na szczęście my możemy sobie wybrać kolor trawy. Zależy on wyłącznie od nas! 



\section{BIBLIOGRAFIA}

Arys to teles (2003), Fizyka; O niebie; O powstawaniu i niszczeniu; Meteorologika; O świecie; Metafizyka, [w:] tenże, Dzieła wszystkie, t. 2, przeł. K. Leśniak, Wydawnictwo Naukowe PWN, Warszawa.

Arys to teles (2009), Metafizyka, przeł. K. Leśniak,Wydawnictwo Naukowe PWN, Warszawa.

Augustyn (1953), O nauczycielu, przeł. J. Modrzejewski; O wolnej woli, przeł. A. Trombala, [w:] te nże, Dialogi filozoficzne, PAX, Warszawa.

Berger P. L., Lu ckmann Th. (1966), The Social Construction of Reality, Anchor Books, New York.

Berger P. L., L u ckmann Th. (1986), Społeczne tworzenie rzeczywistości, przekł. i słowo wstępne J. Niżnik, PIW, Warszawa.

Berkele y G. (2006), Trzy dialogi między Hylasem a Filonousem, przeł. M. Filipczuk, Wydawnictwo Zielona Sowa, Warszawa.

B lo ck N. (1981), Troubles with functionalism, [w:] Readings in the Philosophy of Psychology, Vol. 1, ed. N. Block, Harvard University Press, Cambridge, MA.

B lock N. (1990a), The Computer Model of the Mind, [w:] An Invitation to Cognitive Science, Vol. 3, eds. D. Osherson, E. E. Smith, MIT Press, Cambridge, MA.

Block N. (1990b), Inverted Earth, "Philosophical Perspectives", Vol. 4, ed. J. Tomberlin, Ridgeview Publishing Company, Atascadero, CA.

Block N. (1996), Mental Paint and Mental Latex, "Philosophical Issues", Vol. 7, ed. E. Villenueva, Ridgeview Publishing Company, Atascadero, CA.

B o e cju s z (2006), O pocieszeniu jakie daje filozofia, przeł. G. Kurylewicz, M. Antczak, Wydawnictwo Marek Drewniecki, Kęty.

B remer J. (2005), Jak to jest być świadomym, IFiS PAN, Warszawa.

Bremer J. (2010), Wprowadzenie do filozofii umysłu, WAM, Kraków.

Byrne A. (1994), Behaviourism, [w:] A Companion to the Philosophy of Mind. ed. S. Guttenplan, Basil Blackwell, Oxford.

Ca r roll J. B., ed. (1956). Language, Thought, and Reality: Selected Writings of Benjamin Lee Whorf, Technology Press of MIT, Boston.

Chalmers D. J. (1995), Absent qualia, fading qualia, dancing qualia, [w:] Conscious Experience, ed. T. Metzinger, Verlag Ferdinand Schoningh, Paderborn.

Chalmers D. J. (1996), The Conscious Mind, Oxford University Press, Oxford.

Churchland P. M. (1981), Eliminative materialism and the propositional attitudes, "Journal of Philosophy" 78: 67-90.

Churchland P. M. (1989), A Neurocomputational Perspective, MIT Press, Cambridge, MA.

Churchland P. M. (1994), Folk psychology, [w:] A Companion to the Philosophy of Mind, ed. S. Guttenplan, Basil Blackwell, Oxford.

Churchland P. M. (2002) Mechanizm rozumu, siedlisko duszy. Filozoficzna podróż w głąb tłum. Z. Karaś, Fundacja Aletheia, Warszawa.

Clark A., Chalmers D. (1998), The Extended Mind, "Analysis" 58: 10-23.

Davidson D. (1970), Mental events, [w:] Expirience and Theory, ed. L. Foster, J. W. Swanson, University of Massachusetts Press, Amherst, MA. 
Dennett D. C. (1984), Elbow Room:The Varieties of Free Will Worth Wanting, MIT Press, Cambridge, MA.

Dennett D. C. (1987), The Intentional Stance, MIT Press, Cambridge, MA.

Dennett D. C. (1991), Consciousness Explained, Back Bay Books, New York.

Dennett D. C. (1996), Darwin's Dangerous Idea: Evolution and the Meanings of Life, Simon \& Schuster, London [Reprint edition].

Dretske F. (1996), Phenomenal Externalism or If Meanings Ain't in the Head, Where Are Qualia?, "Philosophical Issues", Vol. 7, ed. E. Villenueva, Ridgeview Publishing Company, Atascadero, CA.

Fo d o r J. (1975), The Language of Thought, MIT Press, Cambridge, MA.

Fodor J. (1981), Computation and reduction, [w:] Representations, ed. J. Fodor, MIT Press, Cambridge, MA.

Fodor J. (1982), Cognitive Science and the Twin-Earth Problem, "Notre Dame Journal of Formal Logic" 23: 98-118.

Fod or J. (1987), Psychosemantics, MIT Press, Cambridge, MA.

Fod or J. (1991a), A Theory of Content and Other Essays, MIT Press, Cambridge, MA.

Fo d or J. (1991b), A Modal Argument for Narrow Content, "Journal of Philosophy" 1: 5-26.

Fo d or J. (1994), Fodor, Jerry A., [w:] A Companion to the Philosophy of Mind. ed. S. Guttenplan, Basil Blackwell, Oxford.

Frankfurt H. (1969), Alternate Possibilities and Moral Responsibility, "Journal of Philosophy" 46 (December): 829-839.

Giży cki J. (1984), Z szachami przez wieki i kraje, Wydawnictwo „Sport i Turystyka”, Warszawa.

Good man N. (1997), Jak tworzymy świat, przeł. M. Szczubiałka, Fundacja Aletheia, Warszawa.

Hinton J. M. (1973), Experiences, Clarendon Press, Oxford.

Horgan T. (1984), Functionalism, qualia, and the inverted spectrum, "Philosophy and Phenomenological Research" 44: 453-469.

Hume D. (1963), Traktat o naturze ludzkiej, przeł. Cz. Znamierowski, PWN, Warszawa.

Jacks on F. (1982), Epiphenomenal Qualia, "Philosophical Quarterly" 32: 127-136.

Jacks on F. (1986), What Mary Didn't Know, "Journal of Philosophy" 83: 291-295.

Kane R. (1996), The Significance of Free Will, Oxford University Press, Oxford.

Kane R. (1999) Respoonsibility, Luck, and Chance:Reflections on Free Will and Indeterminism, "Journal of Philosophy" 96: 217-240.

Kim J. (2002), Umysł w świecie fizycznym, Wydawnictwo IFiS PAN, Warszawa.

Kitcher P. (1984), In defense of intentional psychology, "Journal of Philosophy" 71: 89-106.

Kuhn T. (1968), Struktura rewolucji naukowych, przeł. H. Ostromęcka, wyd. I, PWN, Warszawa.

Leibniz G. W. (1969), Wyznanie wiary filozofa, przeł. J. Domański, PWN, Warszawa.

Libet B. (1985), Unconscious Cerebral Initiative and the Role of Conscious Will in Voluntary Action, "The Behavioral and Brain Sciences" 8: 529-566.

Lycan W. G. (2001), The Case for Phenomenal Externalism, "Philosophical Perspectives", Vol. 15: Metaphisics, Ridgeview Publishing, Atascadero, MA.

Malotki E. (1983), Hopi Time: A Linguistic Analysis of the Temporal Concepts in the Hopi Language. Berlin: Mouton.

Martin M. G. F. (2002), The Transparency of Experience, "Mind and Language" 17: 376-425.

Martin M. G. F. (2003), Particular Thoughts and Singular Thought, [w:] Thought and Language, ed. A. O'Hear, Cambridge University Press, Cambridge.

McDowell J. (1987), Singular Thought and the Extent of Inner Space, [w:] Subject, Thought and Context, eds. J. McDowell, P. Pettit, Oxford University Press, Oxford.

Millik a n R. (1984), Language, Thought and Other Biological Categories, MIT Press, Cambridge, MA. Millikan R. (1989), In Defense of Proper Functions, "Philosophy of Science" 56, No. 2: 288-302.

Papine a u D. (1994), Philosophical Naturalism, Basil Blackwell, Oxford.

Pe re b o om D. (2001), Living Without Free Will, Cambridge University Press, Cambridge.

Poczobut R. (2002), Wieloraka realizacja a redukcja, [w:] Zdarzenia i własności mentalne, red. A. Biłat, Wydawnictwo UMCS, Lublin.

Putna m H. (1975), Philosophical papers, Vol. 2: Mind, Language and Reality, Cambridge University Press, Cambridge. 
Putnam H. (1981), Reason, Truth and History, Cambridge University Press, Cambridge.

Putnam H. (1988), Representation and Reality, MIT Press, Cambridge, MA.

Putnam H. (1992), Renewing Philosophy, MIT Press, Cambridge, MA.

Putnam H. (1998), Wiele twarzy realizmu i inne eseje, przeł. A. Grobler, Wydawnictwo Naukowe PWN, Warszawa.

Putn a m H. (1999), The Threefold Cord, Mind, Body, and World, Columbia University Press, New York. Quine W. V. O. (1969), Z punktu widzenia logiki, przeł. B. Stanosz, PWN, Warszawa.

Quine W. V. O. (1986), Granice wiedzy i inne eseje filozoficzne, przeł. B. Stanosz, PWN, Warszawa

Quine W. V. O. (1993), Trzy niezdeterminowania, przeł. B. Stanosz, [w:] Filozofia języka, t. 1, wybór i wstęp B. Stanosz, Fundacja Aletheia, Warszawa.

Quine W. V. O. (1998), Od bodźca do nauki, przeł. B. Stanosz, Fundacja Aletheia, Warszawa.

Quine W. V. O. (1999), Słowo i przedmiot, przeł. C. Cieśliński, Fundacja Aletheia, Warszawa.

Quine W. V. O. (2000a), Różności: słownik prawie filozoficzny, przeł. C. Cieśliński, Fundacja Aletheia, Warszawa.

Quine W. V. O. (2000b), Z punktu widzenia logiki: dziewięć esejów logiczno-filozoficznych, przeł.

B. Stanosz, Fundacja Aletheia, Warszawa.

Quine W. V. O. (2002), Filozofia logiki, przeł. B. Stanosz, Fundacja Aletheia, Warszawa.

Ryle G. (1970), Czym jest umysł?, przeł. W. Marciszewski, PWN, Warszawa.

Sapir E. (1978), Kultura, język, osobowość, PIW, Warszawa.

Searle J. (1994), The Rediscovery of Mind, MIT Press, Cambridge, MA.

Searle J. (1995), Umysły, mózgi i programy, przeł. B. Chwedeńczuk, [w:] Filozofia umysłu, t. 3, wybór i wstęp B. Chwedeńczuk, Fundacja Aletheia, Warszawa.

Se arle J. (1984), Minds, Brains and Science, Harvard University Press, Cambridge, MA.

Se arle J. (1997), The Mystery of Consciousness, Review of Books, New York.

Sellars W. (1956), Empiricism and the philosophy of mind, "Minnesota Studies in the Philosophy of Science", Vol. 1, University of Minnesota Press, Minneapolis.

Singer P. (1997), O życiu i śmierci. Upadek etyki tradycyjnej, przeł. A. Alichniewicz, A. Szczęsna, Wydawnictwo Naukowe PWN, Warszawa.

Snowdon P. F. (1979-1980), Perception, Vision and Causation, "Proceedings of the Aristotelian Society" 81: 175-192.

Stich S. P. (1979), Do Animals Have Beliefs?, "Australasian Journal of Philosophy" 57: 15-29.

Stich S. P. (1983), From Folk Psychology to Cognitive Science: The Case Against Belief, MIT Press, Cambridge, MA.

Strawson G. (1994), Mental Reality, MIT Press, Cambridge, MA.

Swinburne R. (1977), The Coherence of Theism, Oxford University Press, Oxford.

Tye M. (1995), Ten Problems of Consciousness, Bradford Books-MIT Press, Cambridge, MA.

Tye M. (2006), Absent Qualia and the Mind-Body Problem, "Philosophical Review" 115: 139-168.

Van Inwagen P. (1983), An Essay on Free Will, Clarendon Press, Oxford.

Van In wa ge n P. (2008), What Does An Omniscient Being Know About the Future?, "Oxford Studies in Philosophy of Religion", Vol. 1, ed. J. Kvanvig, Oxford University Press, Oxford.

Wh orf B. L. (2002), Język, myśl i rzeczywistość, przeł. T. Hołówka, Wydawnictwo KR, Warszawa.

Wittgenste in L. (2000), Dociekania filozoficzne, przekł., wstęp i przypisy B. Wolniewicz, wyd. II, Wydawnictwo Naukowe PWN, Warszawa.

Że g le ń U. (2003), Filozofia umysłu. Dyskusja z naturalistycznymi koncepcjami umysłu, A. Marszałek, Toruń. 